Faculdade de Arquitetura e Urbanismo

Universidade de São Paulo

\title{
O IMPACTO DA VEGETAÇÃO NOS MICROCLIMAS URBANOS
}

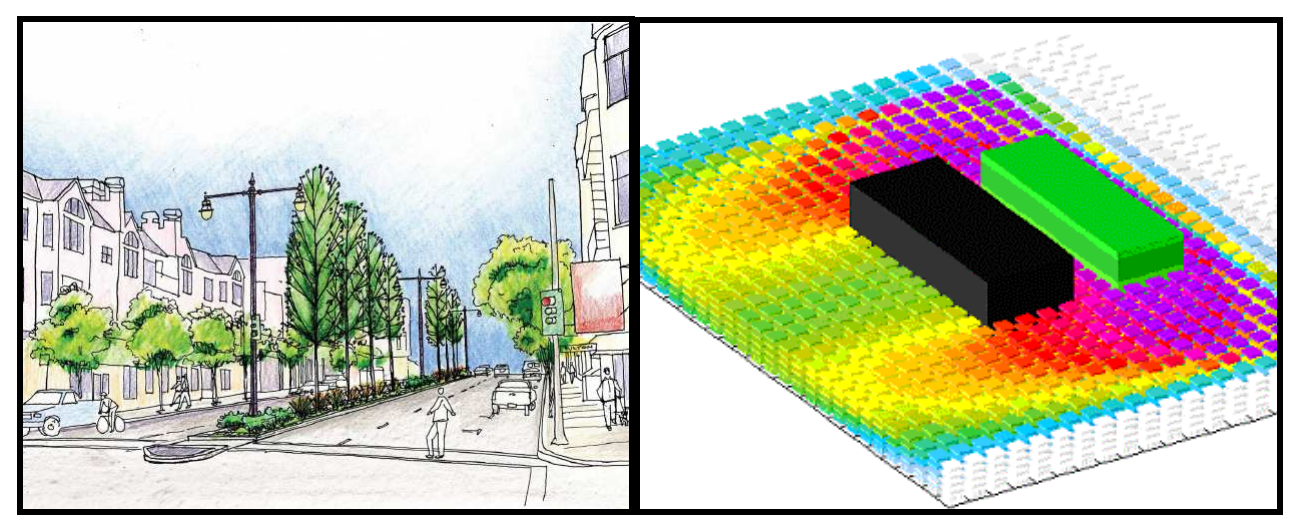

Paula Shinzato

São Paulo 


\section{O impacto da vegetação nos microclimas urbanos}

\section{Paula Shinzato}

Dissertação de Mestrado apresentada a

Faculdade de Arquitetura e Urbanismo da

Universidade de São Paulo, para obtenção do

Titulo de Mestre em Arquitetura e Urbanismo

Área de Concentração: Tecnologia da Arquitetura

Orientadora Prof. Dra. Denise H. S. Duarte

São Paulo

2009 
AUTORIZO A REPRODUÇÃO E DIVULGAÇÃO TOTAL OU PARCIAL DESTE TRABALHO, POR QUALQUER MEIO CONVENCIONAL OU ELETRÔNICO, PARA FINS DE ESTUDO E PESQUISA, DESDE QUE CITADA A FONTE.

EMAIL: paulashinzato@yahoo.com

Shinzato, Paula

S555i O impacto da vegetação nos microclimas urbanos / Paula Shinzato. --São Paulo, 2009. 173 p. : il.

Dissertação (Mestrado - Área de Concentração: Tecnologia da Arquitetura) - FAUUSP.

Orientadora: Denise Helena Silva Duarte

1.Microclima urbano 2.Imapctos ambientais 3.Vegetação I.Título

CDU 551.558.7 


\section{DEDICATÓRIA}

PAULA SHINZATO

À Daisaku Ikeda, meu mestre da vida, pelos contínuos incentivos; À minha família pelo apoio em todos os momentos; Ao Alessandro, pela ajuda durante a pesquisa. 


\section{AGRADECIMENTOS}

À Fundação de Amparo à Pesquisa do Estado de São Paulo - FAPESP pelo apoio no desenvolvimento da pesquisa.

À minha orientadora Prof. Dra. Denise Helena Silva Duarte pelo acompanhamento em todas as etapas da pesquisa e o claro direcionamento que possibilitou atingir os objetivos pretendidos no estudo sobre a vegetação urbana.

Às prof. Dra. Marcia Alucci e Dra. Joana Gonçalves por contribuírem na discussão sobre o tema com sugestões e questionamentos importantes.

Aos pesquisadores Dr. Erik Johansson e MSc. Jörg Spangenberg por compartilhar seus conhecimentos e ajudar nos estudos aplicados para o programa ENVI-met.

Aos pesquisadores e amigos do Laboratório de Conforto Ambiental e Eficiência Energética - LABAUT: Rafael Brandão, Leonardo Monteiro, Norberto Moura, Alessandra Prata, Erika Umakoshi, Mariana Lino Gouveia, Monica Marcondes, Juliana Azem Ribeiro de Almeida, Bruna Luz, Anna Miana, Lara Del Bosco, Mariana Afonso, Erik Johansson e Jörg Spangengerg pela colaboração nas medições de campo no bairro da Luz e pelas valiosas conversas.

À prof. Berta Lange de Morretes por dividir seus conhecimentos e ensinamentos sobre a vida.

À pesquisadora Mariana Lino Gouveia por ajudar nos dados de entrada do ENVI-met.

Ao prof. Demóstenes Ferreira da Silva Filho e a equipe de pesquisadores da ESALq pelo auxílio nas medições do Índice de Área Foliar e pela indicação de materiais para a pesquisa.

Aos meus pais pelo apoio incondicional e todos os incentivos voltados ao estudo e autoaprimoramento.

Aos meus irmãos, Daniela e Marcelo pelo constante estímulo e compreensão.

Ao Alessandro pela ajuda na revisão da pesquisa, pela paciência e carinho. 


\section{RESUMO}

O objeto desta pesquisa são os efeitos da vegetação nas condições microclimáticas urbanas, partindo-se da premissa que a presença da vegetação influencia o microclima do seu entorno imediato. A partir de diferentes formas de distribuição das áreas verdes na cidade e com o uso de espécies locais, o objetivo é quantificar a intensidade e a distribuição espacial dos efeitos microclimáticos da vegetação, principalmente as alterações de temperatura do ar e superficial no nível do pedestre, utilizando-se modelos de balanço de energia e ferramentas computacionais.

Foram feitas simulações paramétricas no ENVI-met a fim de investigar o efeito da distribuição de áreas verdes (linear, grandes massas verdes concentradas ou pequenos agrupamentos distribuídos em diferentes distâncias) e por meio das medições de campo pode-se quantificar a importância da vegetação (gramíneas, arbustos e arbóreas) nos aspectos climáticos.

Os resultados mostram que o efeito da vegetação é local e não ocorre uma influência significativa muito além dos limites das áreas verdes. Em relação à intensidade do efeito da vegetação, a diferença média entre as temperaturas do ar nas áreas verdes arborizadas e as ruas adjacentes é de $1.5^{\circ} \mathrm{C}$. Já o sombreamento pelas árvores de copa densa (LAI=10), mostrou diferenças médias de $23^{\circ} \mathrm{C}$, nas temperaturas superficiais do solo, embaixo da copa.

Esse resultado indica que o uso das árvores é uma estratégia para amenizar o efeito de ilha de calor nas metrópoles, pois evita o aquecimento de materiais como asfalto e concreto e a liberação da radiação de onda longa acumulada durante a noite. 


\begin{abstract}
The main purpose of this research is the effects of vegetation in urban microclimate conditions, under the premise that the presence of vegetation influences the microclimate and its surroundings. Considering different forms of green space distribution and using native species, it could quantify the intensity and spatial distribution for the microclimate effects by a vegetated area. The modifications of air temperature and the surface temperature at the level of the pedestrians were analyzed based on energy balance and computer models.

Parametric simulations on ENVI-met were done to investigate the effect of green areas distribution (linear forms, large mass of vegetation and small groups of trees) and were compared with on-site measurement data. The simulation results showed the impact of urban vegetation for climatic aspects.

The outputs indicated that the vegetation effect is local and do not have a significant influence beyond the limits of the green area. Regarding to the intensity of vegetation effect, the average difference between air temperature under the trees and above the streets is $1.5^{\circ} \mathrm{C}$. While the shadowing of a dense tree $(\mathrm{LAI}=10)$ showed an average difference of $23^{\circ} \mathrm{C}$ for superficial temperatures between green spaces and the street.

This result pointed out that green area is an important strategy to mitigate the heat island effect in city centers, as it can prevent asphalt and concrete from heating and releasing long wave radiation during night time.
\end{abstract}




\section{LISTA DE FIGURAS}

Figura 1: Isotermas do Efeito de Ilha de Calor (a) e as diferenças de temperatura do ar para o dia e a noite (b).

Figura 2: Propostas iniciais de distribuição da vegetação nas simulações paramétricas.25

Figura 3: Temperatura de Superfície por meio do sombreamento das árvores. 33

Figura 4: Estudos do sombreamento das árvores na fachada oeste e sul para os períodos de verão e inverno. 33

Figura 5: A redução da velocidade dos ventos $(\%)$ em relação à distância do grupo de árvores com diferentes densidades das copas (distância de acordo com a altura das árvores) . 35

Figura 6: Efeito das árvores na velocidade dos ventos. 35

Figura 7: Relação entre pavimento impermeável e escoamento das águas da chuva..... 36

Figura 8: Diferentes sistemas para retenção das águas: a) área de drenagem mais baixa, b) fossos e valetas, c) lagos de retenção permanente, d) cisternas de coleta subterrânea.

Figura 9: Foto aérea das ruas arborizadas da cidade de Sacramento, Califórnia. 49

Figura 10: Análise da foto aérea pelo modelo UFORE.

Figura 11: Árvores existentes no bairro Alamo Square por meio do Map Guide Open

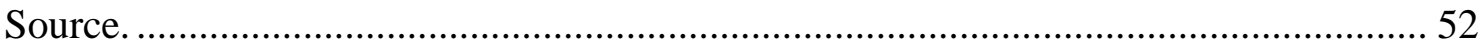

Figura 12: Telhado Verde na cobertura da Prefeitura de Chicago. .............................. 52

Figura 13: Proposta para Arborização urbana na cidade de Los Angeles, Califórnia.... 53

Figura 14: Plano Regional para implantação de novas áreas verdes na cidade de

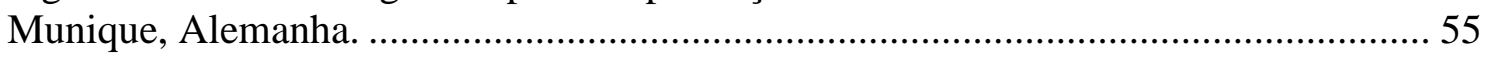

Figura 15: Programa East London Green Grid.......................................................... 56

Figura 16: Seis Grupos de Trabalho - Programa East London Green Grid..................... 56

Figura 17: Modelo de residência com telhado verde em Malmö. .................................. 57

Figura 18: Implantação de terraços com vegetação nativa em Malmö. ......................... 57

Figura 19: Cobertura vegetal na área mais urbanizada da cidade de Malmö, Suécia. ... 58

Figura 20: Proposta para interligação das Áreas Verdes - Green Network. ................... 58

Figura 21: Processo de criação da rede verde na cidade de Tóquio................................ 60

Figura 22: Integração das árvores existentes intercaladas por árvores de médio porte.. 60

Figura 23: Integração das áreas verdes com projetos de edifícios comerciais. Nishi

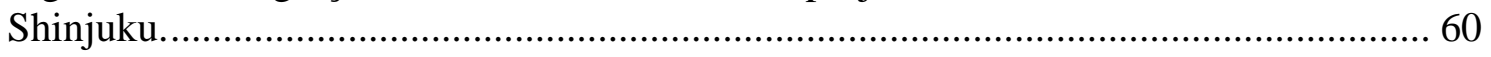

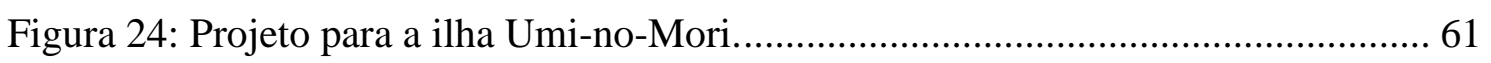

Figura 25: Proposta para construção de novas unidades residenciais e a infraestrutura verde necessária para o desenvolvimento da cidade de Pequim. 
Figura 26: Telhado verde na Universidade Tecnológica Nanyang em Cingapura......... 63

Figura 27: Proposta urbana do Fusionolopis

Figura 28: Construção de telhados verdes na cobertura dos esdifícios. Projeto Fusinopolis. 64

Figura 29: Lateral de um dos edifícios com vegetação na fachada. Projeto Fusionopolis. 64

Figura 30: O Projeto South Beach no centro de Cingapura. 64

Figura 31: Estratégias bioclimáticas no projeto South Beach. 64

Figura 32: Arborização urbana na cidade de Cingapura 65

Figura 33: Fachada com vegetação. Cidade de Cingapura. 65

Figura 34: Arborização nas vias de Maringá. 66

Figura 35: Andamento das obras do Parque Linear do Sapé, no Butantã. 68

Figura 36: Andamento das obras do Parque Linear da Invernada, em Santo Amaro..... 68

Figura 37: A relação entre o comprimento de onda e os valores de transmissão, reflexão e absorção.

Figura 38: Balanço da radiação que acontece na parte superior e inferior da folha....... 75

Figura 39: Laminar Boundary Layer sobre a folha. .................................................... 78

Figura 40: Trocas gasosas pela abertura dos estômatos na superfície da folha............... 81

Figura 41: Presença de estômatos nas folhas............................................................. 81

Figura 42: Relação entre o albedo da vegetação e sua altura. ....................................... 84

Figura 43: Fluxo esquemático envolvendo o balanço de energia da vegetação (a) e o

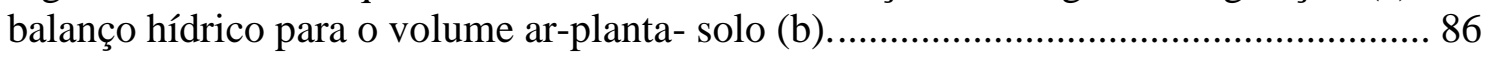

Figura 44: Características da escala local determinada pelo modelo LUMPS............... 88

Figura 45: Apresentação das principais ferramentas oferecidas pelo Envi-met para análise da vegetação. 96

Figura 46: Layout básico do modelo ENVI-met. 98

Figura 47: Distribuição das alturas: Eqüidistante (A), Telescópico com fator de extensão (B) e Telescópico (C). 98

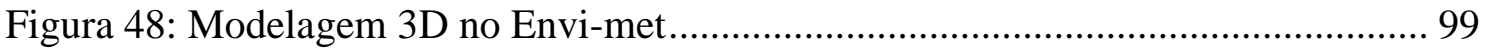

Figura 49: Opções do formato final a ser simulado no modelo ENVI-met.................. 100

Figura 50: Resultados de simulações geradas pelo Leonardo (2D)............................ 100

Figura 51: Resultados de simulações geradas pelo Leonardo (3D)............................. 100

Figura 52: Quadro de Configuração do Modelo de Cálculo da Vegetação.................. 102

Figura 53: Imagem do mapa de Temperatura Aparente da Superfície - 03/09/1999 às 9:57 - com indicação dos principais parques na região central. 108 
Figura 54: Localização dos três pontos de medição na área da Luz na primeira etapa. 109 Figura 55: Localização do pontos fixos e do transecto na área da Luz na segunda medição 110

Figura 56: Localização e posicionamento do equipamento no Parque da Luz 111

Figura 57: Entorno da área do ponto 1

Figura 58: Localização e posicionamento do equipamento na praça

Figura 59: Entorno da área do ponto 2 Estação da Luz e Shopping Luz

Figura 60: Localização e posicionamento do equipamento no canyon ....

Figura 61: Entorno da área do ponto 3 estabelecimentos comerciais e edifícios altos residenciais

Figura 62: Foto grande angular do parque da luz (1); foto grande angular da praça (2); foto grande angular do canyon (3) - primeira etapa................................................... 113

Figura 63: Localização e posicionamento do equipamento no parque P1 ................... 114

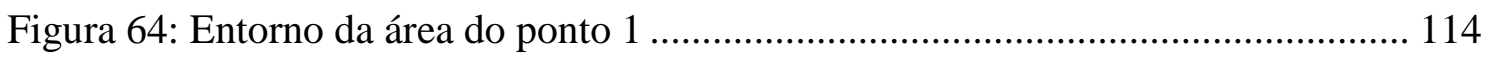

Figura 65: Localização e posicionamento do equipamento no parque P2 …............... 115

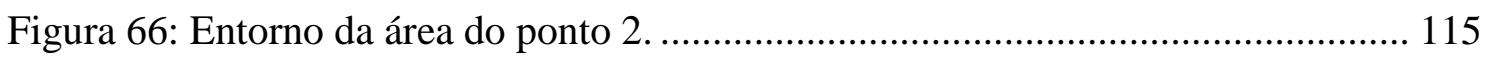

Figura 67: Localização e posicionamento do equipamento na calçada da Estação da Luz P3 (fotos: L. Monteiro).

Figura 68: Localização e posicionamento do equipamento na calçada da Estação da Luz P3 (fotos: L. Monteiro).

Figura 69: Localização e posicionamento do equipamento no transecto na Avenida Casper Líbero (fotos: L. Monteiro).

Figura 70: Foto grande angular do parque da luz (1); foto grande angular no portão do parque (2); foto grande angular da Estação da Luz (3) (fotos: L. Monteiro). ............... 117

Figura 71: Projeção do diâmetro da copa.

Figura 72: Exemplo de LAI - Distribuição da quantidade de folhas em relação ao diâmetro da copa.

Figura 73: Perfil do LAD proposto para uma árvore com LAI $=10$. No eixo $\mathrm{x}$ os valor de LAD e no eixo y a altura da cada camada em metros........................................... 125

Figura 74: Equipamento LAI-2000 Plant Canopy Analyzer...................................... 127

Figura 75: Medição LAI - Fotografia da árvore inteira a uma distância de 20m......... 129

Figura 76: Medição LAI - Tratamento da foto, deixando apenas a copa...................... 129

Figura 77: Medição LAI - Criação da moldura no entorno da copa.............................. 129

Figura 78: Modelo de Simulação com três receptores. .................................................. 132

Figura 79: Comparação das temperaturas do ar medidas e simuladas (configuração inicial)...... 
Figura 80: Comparação das temperaturas de superfície medidas e simuladas (configuração inicial). 134

Figura 81: Resultados de temperatura do ar para as diferentes velocidades do vento. 135

Figura 82: Resultados de temperatura do ar para os diferentes tipos de nesting grids. 136

Figura 83: Resultados de temperatura do ar para diferentes valores de temperatura inicial da atmosfera.

Figura 84: Resultados de temperatura do ar para diferentes valores de umidade relativa do solo.

Figura 85: Comparação das temperaturas do ar medidas e simuladas (configuração final $-\mathrm{B} 1)$.

Figura 86: Perfil do LAD proposto para dois tipos de árvores (T3 e T4), no eixo x os valor de LAD e no eixo y a altura da cada camada em metros.

Figura 87: Um canyon formado por edifícios de $24 \mathrm{~m}$ de altura e duas faixas de $160 \mathrm{~m}^{2}$ (4m x 40m) com gramíneas.

Figura 88: Resultado da simulação ENVI-met para temperatura do ar no cenário 1 às $14 \mathrm{~h}$.

Figura 89: Resultado da simulação ENVI-met para temperatura superficial no cenário 1

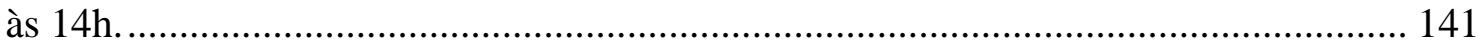

Figura 90: Um canyon formado por edifícios de $24 \mathrm{~m}$ de altura e duas faixas de $160 \mathrm{~m}^{2}$ (4m x 40m) com gramíneas e espécies arbóreas pouco densas (T3), colocadas a cada $4 \mathrm{~m}$.

Figura 91: Resultado da simulação ENVI-met para temperatura do ar no cenário 2 às $14 \mathrm{~h}$.

Figura 92: Resultado da simulação ENVI-met para temperatura superficial no cenário 2 às $14 \mathrm{~h}$.

Figura 93: Um canyon formado por edifícios de $24 \mathrm{~m}$ de altura e duas faixas de $160 \mathrm{~m}^{2}$ (4m x 40m) com gramíneas e espécies arbóreas muito densas (T4), colocadas a cada $4 \mathrm{~m}$.

Figura 94: Resultado da simulação ENVI-met para temperatura do ar no cenário 3 às $14 \mathrm{~h}$.

Figura 95: Resultado da simulação ENVI-met para temperatura superficial no cenário 3 às $14 \mathrm{~h}$

Figura 96: Definição dos parâmetros de modelagem do Base Case, baseados nos estudos de.....

Figura 97: Proposta dos cenários para a simulação no ENVI-met.

Figura 98: Modelo 3D do Cenário Base Case sem vegetação. Apresenta 9 quadras com $24 \mathrm{~m}$ de altura no formato perimetral e sem vegetação.

Figura 99: Simulação Cenário Base Case - Temperatura do Ar às 14h. 148

Figura 100: Simulação Cenário Base Case - Temperatura Superficial às 14h. 148 
Figura 101: Modelo 3D do Cenário 4 com vegetação na quadra central. Formado por 8 quadras com edifícios com 24m de altura e 1 quadra com árvores T4 (LAI=10)........ 148

Figura 102: Simulação Cenário 4 - Temperatura do ar às 14h. ................................... 149

Figura 103: Simulação Cenário 4 - Temperatura Superficial às 14h........................... 149

Figura 104: Modelo 3D do Cenário 5 com vegetação de forma linear. Formado por 6 quadras com edifícios de $24 \mathrm{~m}$ de altura, 3 quadra com árvores T4 (LAI=10) e espelho

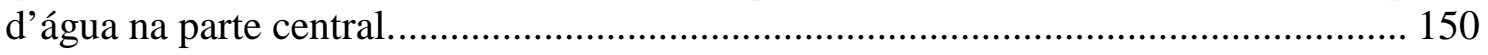

Figura 105: Simulação Cenário 5 - Temperatura do Ar às 14h.................................. 150

Figura 106: Simulação Cenário 5 - Temperatura Superficial às 14h.......................... 151

Figura 107: Modelo 3D do Cenário 6 com pequenos parques. Formado por 9 quadras com edifícios de $24 \mathrm{~m}$ de altura e 9 pequenos parques com árvores T4 (LAI=10)....... 151

Figura 108: Simulação Cenário 6 - Temperatura do Ar às 14h................................. 152

Figura 109: Simulação Cenário 6 - Temperatura Superficial às 14h......................... 152

Figura 110: Modelo 3D do Cenário 7 com arborização nas vias. Formado por 9 quadras com edifícios de 24m de altura e árvores T4 (LAI=10) nas calçadas. ......................... 152

Figura 111: Simulação Cenário 7 - Temperatura do Ar às 14h................................. 153

Figura 112: Simulação Cenário 7 - Temperatura Superficial às 14h.......................... 153

Figura 113: Modelo 3D do Cenário 8 com arborização nas vias. Formado por 9 Quadras com edifícios de 24m de altura e árvores T4 (LAI=10) no miolo de quadra. ............... 154

Figura 114: Simulação Cenário 8 - Temperatura do Ar às 14h................................. 154

Figura 115: Simulação Cenário 8 - Temperatura Superficial às 14h......................... 155

Figura 116: Área definida para simulação no ENVI-met........................................... 155

Figura 117: Proposta de inserção da vegetação na área da Luz. ................................. 156

Figura 118: Simulação Proposta Área da Luz - Temperatura do Ar às 14h............... 156

Figura 119: Simulação Proposta Área da Luz - Temperatura Superficial às 14h........ 157 


\section{LISTA DE TABELAS}

Tabela 1: Grau de Impermeabilidade dos Materiais.

Tabela 2: Coeficientes médios para absorção, reflexão e transmissão em quatro principais bandas de comprimento de onda.

Tabela 3: Principais Variáveis utilizadas pelo ENVI-met. 95

Tabela 4: Descrição dos dados de entrada do modelo ENVI-met. 138

Tabela 5: Descrição dos dados de entrada do modelo ENVI-met - Modelo Paramétrico com nove quadras 
PAULA SHINZATO

\section{LISTA DE GRÁFICOS}

Gráfico 1: Comparativo das temperaturas do ar obtidas na primeira etapa de medição

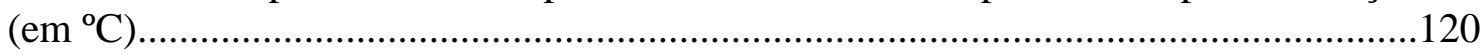

Gráfico 2: Comparativo das umidades relativas ao ar obtidas na primeira etapa de medição (em \%)

Gráfico 3: Comparativo das temperaturas obtidas na segunda etapa de medição (em $\left.{ }^{\circ} \mathrm{C}\right)$

Gráfico 4: Comparativo das umidades relativas do ar obtidas na segunda etapa de medição (em \%). 


\section{SUMÁRIO}

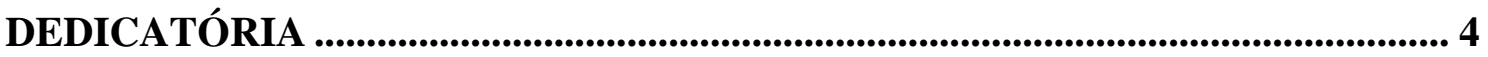

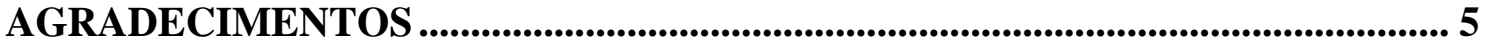

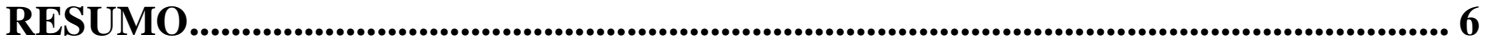

ABSTRACT

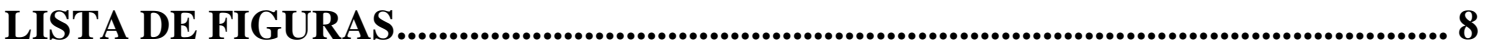

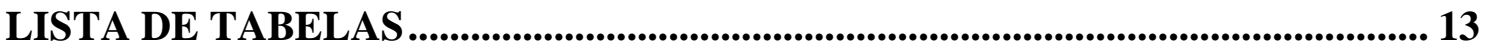

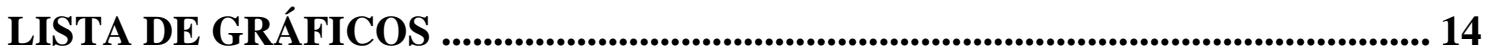

1. INTRODUÇÃO E JUSTIFICATIVA PARA A PESQUISA ............................ 18

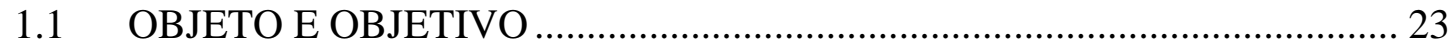

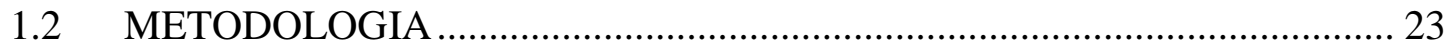

1.2.1 PESQUISA BIBLIOGRÁFICA E LEVANTAMENTO DE DADOS

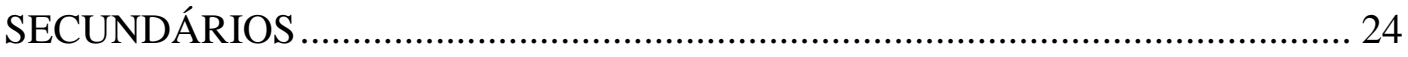

1.2.2 LEVANTAMENTO DE DADOS PRIMÁRIOS .................................. 24

1.2.3 AVALIAÇÃO QUANTITATIVA DO EFEITO DA VEGETAÇÃO ..... 26

1.2.4 ANÁLISE DOS RESULTADOS E CONCLUSÕES ........................... 27

1.3 ESTRUTURA DA DISSERTAÇÃO......................................................... 27

1 A INFLUÊNCIA DA VEGETAÇÃO NA QUALIDADE AMBIENTAL

URBANA E POLÍTICAS PUBLICAS DE ARBORIZAÇÃO ................................... 30

2.1 INTRODUÇÃO AOS BENEFÍCIOS DA VEGETAÇÃO.............................. 30

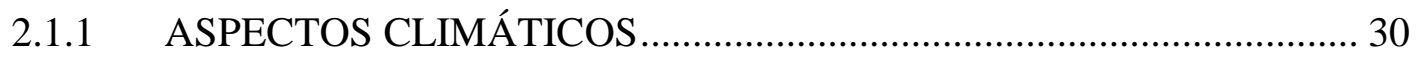

2.1.2 ASPECTOS ECOLÓGICOS RELACIONADOS À ÁGUA .................... 36



2.1.4 ASPECTOS RELACIONADOS À FAUNA …...................................... 40 
2.2 POLÍTICAS PÚBLICAS DE ARBORIZAÇÃO URBANA 41

2.2.1 ALGUMAS POLÍTICAS PÚBLICAS NOS ESTADOS UNIDOS ........ 48

2.2.2 ALGUMAS POLÍTICAS PÚBLICAS NA EUROPA........................... 54

2.2.3 ALGUMAS POLÍTICAS PÚBLICAS NA ÁSIA ................................. 58

2.2.4 ALGUMAS POLÍTICAS PÚBLICAS NO BRASIL............................. 65

3 O EFEITO DA VEGETAÇÃO NO MICROCLIMA URBANO E ALGUNS MODELOS DE CÁLCULO MAIS REPRESENTATIVOS ................................. 70

3.1 PROPRIEDADES TÉRMICAS DAS FOLHAS ….................................... 72

3.2 BALANÇO DE ENERGIA DA FOLHA .................................................... 77

3.3 PROPRIEDADES TÉRMICAS DAS ÁRVORES ....................................... 82

3.4 BALANÇO DE ENERGIA DA VEGETAÇÃO …....................................... 85

3.5 MODELOS QUE SIMULAM O IMPACTO DA VEGETAÇÃO SOBRE O

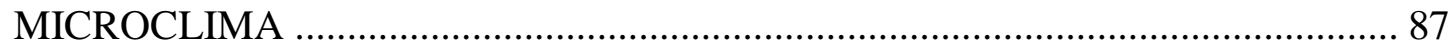

3.6 RELEVÂNCIA DO ENVI-MET PARA ESTA PESQUISA .......................... 92

4 APLICAÇÕES DO MODELO ENVI-MET NESTA PESQUISA..................... 94

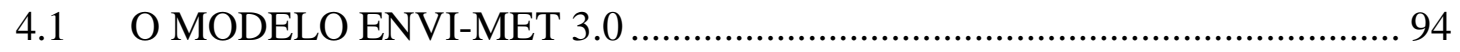

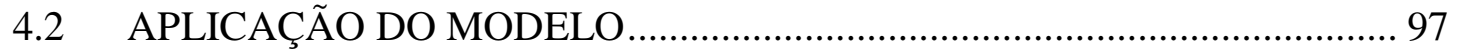

4.4 LIMITAÇÕES DO MODELO ENVI-MET …............................................. 106

5 MEDIÇÕES DE CAMPO ............................................................................. 107

5.1 MEDIÇÕES MICROCLIMÁTICAS NA ÁREA DA LUZ …....................... 107

5.2 MEDIÇÕES DO ÍNDICE DE ÁREA FOLIAR - LAI ............................... 123

6. SIMULAÇÕES PARAMÉTRICAS NO ENVI-MET SEM VEGETAÇÃO . 131



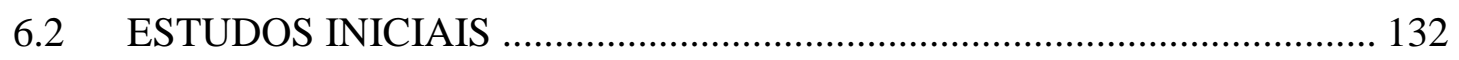

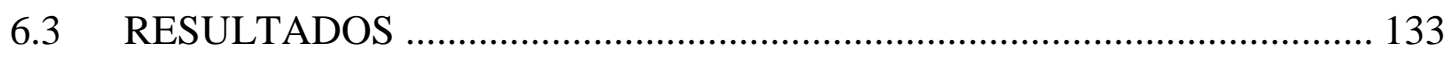


6.4 RESULTADOS FINAIS 138

7. SIMULAÇÕES PARAMÉTRICAS NO ENVI-MET COM VEGETAÇÃO 140

7.1 SIMULAÇÕES EM PEQUENA ESCALA. 141

7.2 SIMULAÇÃO EM MÉDIA ESCALA 145

7.3 SIMULAÇÃO PARA A ÁREA DA LUZ 155

8. ANÁLISE DOS RESULTADOS, CONSIDERAÇÕES FINAIS E CONCLUSÕES. 158

8.1 ANÁLISE DOS RESULTADOS Erro! Indicador não definido.

8.2 CONSIDERAÇÕES FINAIS Erro! Indicador não definido.

8.3 CONCLUSÃO 160

9. REFERÊNCIA S BIBLIOGRÁFICAS 161 


\section{INTRODUÇÃO E JUSTIFICATIVA PARA A PESQUISA}

Atualmente existem evidências claras do aumento da temperatura nos centros urbanos como resultados das atividades humanas. Os impactos negativos do aquecimento global nas cidades têm como conseqüências o aumento das chuvas, enchentes, períodos de seca e destruição dos ecossistemas naturais.

Santamouris (2001) aponta possíveis causas para explicar as mudanças climáticas:

- Variação na quantidade de energia solar. De acordo com medições feitas entre 1979 e 1980, a superfície do sol se resfriou em $6^{\circ} \mathrm{C}$ e essa mudança afeta as condições climáticas da Terra, sendo que o decréscimo de $1 \%$ na energia solar representaria o aumento de $1{ }^{\circ} \mathrm{C}$ na temperatura média do ar.

- Variação na órbita da Terra. Segundo a teoria de Milankovitch (1930), as mudanças na órbita da Terra produzem variações na quantidade de energia solar que chegam à superfície terrestre.

- Modificações na superfície terrestre. A terra é formada por placas tectônicas que estão em constante movimento. A mudança é muito lenta, mas modifica o transporte de calor e o sistema global de ventos.

- Variação na atmosfera. A mudança climática é influenciada pelos gases existentes na atmosfera, permitindo a passagem da radiação solar de onda curta e bloqueando parte da radiação de onda longa emitida pela superfície terrestre. $\mathrm{O}$ efeito estufa depende da concentração de gases como $\mathrm{CO}_{2}$ (dióxido de carbono) e outros como $\mathrm{CH}_{4}$ (metano), $\mathrm{N}_{2} \mathrm{O}$ (óxido nitroso), $\mathrm{O}_{3}$ (ozônio) que absorvem a radiação infravermelha emitida pela superfície da Terra e irradiam por sua vez alguma parcela da energia absorvida de volta para a superfície, causando o aquecimento do ar.

- Variação no albedo das superfícies devido à vegetação. $O$ albedo é a relação entre radiação solar incidente e refletida. As mudanças no albedo das superfícies influenciam na quantidade de calor absorvido e refletido. Assim, apesar da área continental representar $29 \%$ da área total da Terra, esta é a parte que mais vem 
sofrendo alterações nos últimos anos. Os resultados de modelos climáticos apontam que a modificação do albedo causado pela redução da área de vegetação resulta em diminuição de nuvens e precipitação, uma vez que existe a perda no fluxo de calor latente.

- Modificações do clima no ambiente urbano. Ao examinar o clima de uma pequena região, observa-se o mesoclima da área local. Nesta escala as atividades humanas têm maior influência na mudança climática, gerando um ambiente urbano diferente das regiões rurais (Tarifa, 2001). Algumas características físicas dos centros urbanos têm efeito sobre o clima desses locais. Entre elas, a localização dos mesmos numa determinada região; a densidade da área urbana; a orientação e largura das ruas e a altura relativa das edificações; os parques urbanos e áreas verdes (Givoni, 1994 apud Bartholomei, 1998).

As estruturas urbanas, volumes e materiais afetam as condições atmosféricas próximas a estas superfícies (Wilmers, 1990). Essas mudanças têm como um dos resultados o aumento da temperatura do ar, gerando o efeito de Ilha de Calor nos centros urbanos densamente ocupados (Santamouris, 2001).

Na definição dada por Voogt (2004), o efeito de ilha de calor é o nome dado para descrever o processo de aquecimento, tanto na atmosfera, quanto nas superfícies urbanas, quando comparado com as áreas de entorno, menos urbanizadas. Segundo Oke (1982), uma das principais causas para o aquecimento durante a noite é a relação $\mathrm{H} / \mathrm{W}^{1}$, com menor fator de visão de céu. Outras causas são: a mudança na propriedade dos materiais da superfície do tecido urbano e a redução no processo de evapotranspiração das plantas.

As principais características deste fenômeno foram apresentadas por Voogt (2004) como sendo:

- A forma espacial do efeito de Ilha de Calor. As isotermas (linhas com mesma temperatura) seguem um formato de "ilha" nas áreas próximas aos centros urbanos (figura 2), mostrando que as temperaturas mais elevadas estão concentradas nos centros das cidades.

\footnotetext{
${ }^{1}$ Relação da altura dos edifícios com a largura da rua (height/ width).
} 
(a)
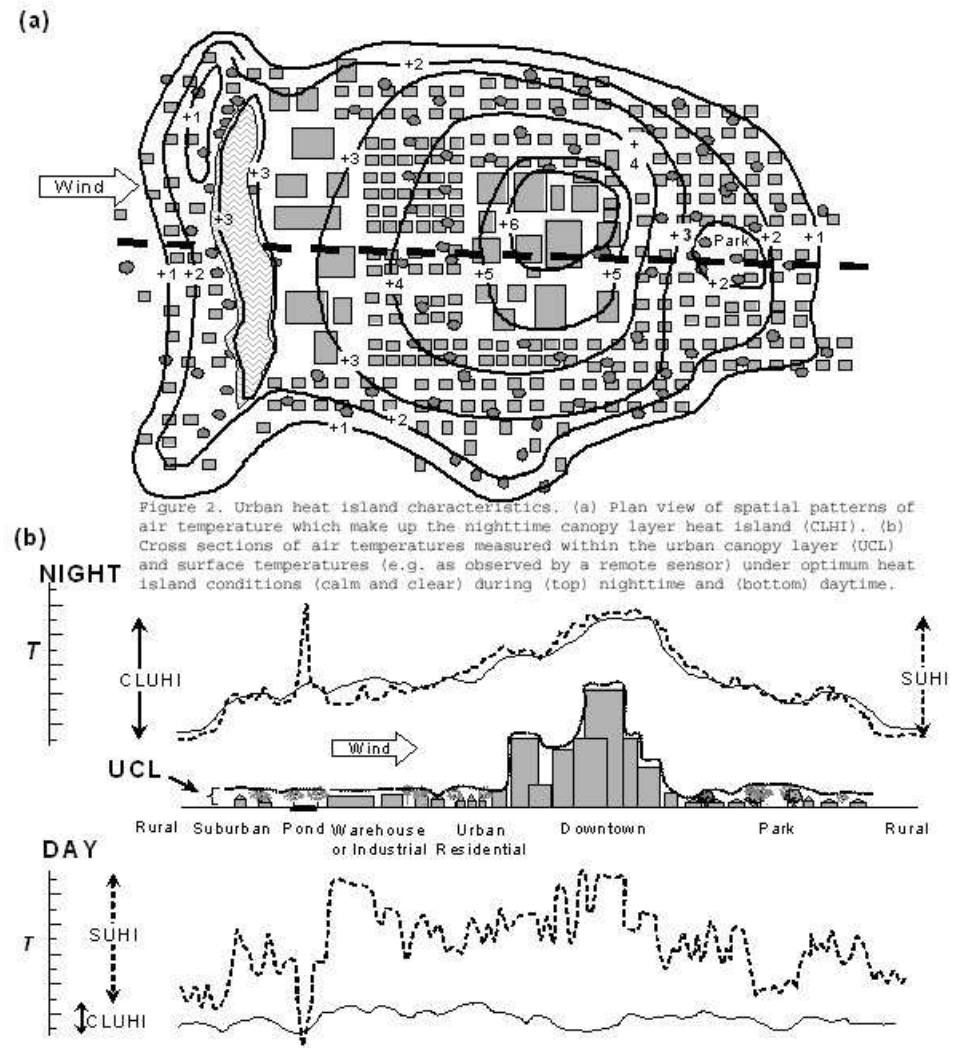

Figura 1: Isotermas do Efeito de Ilha de Calor (a) e as diferenças de temperatura do ar para o dia e a noite (b).

Fonte: Voogt (2004).

- Intensidade do Efeito de Ilha de Calor. Durante o dia, a radiação solar aquece as superfícies e este calor é armazenado nos materiais urbanos, sendo liberado no período noturno. Percebe-se altas temperatura à noite, mesmo sem a radiação solar.

- Características das superfícies dos materiais. As temperaturas de superfície são influenciadas pelas seguintes condições: período (dia ou noite), quantidade de água (seco ou úmido), cor (clara ou escura) e posição (sombreada ou exposta). Em conseqüência, a temperatura do ar corresponde ao aquecimento das superfícies, sendo que nas áreas das cidades a temperatura é mais elevada do que em parques.

Segundo Santamouris (2001), o fenômeno de ilha de calor é caracterizado por uma importante variação espacial e temporal em relação ao clima, topografia, geometria urbana e as condições meteorológicas a curto prazo. Givoni (1991) acredita que a 
geometria do canyon $^{2}$, as propriedades dos materiais, o efeito estufa e a redução de superfícies evaporativas são os fatores determinantes para a existência do efeito de Ilha de Calor.

A ausência de vegetação, problema encontrado na maioria dos grandes centros, contribui para a formação do efeito da ilha de calor na medida em que prejudica mecanismos fundamentais para a redução da temperatura nas cidades: o sombreamento, a filtragem da poluição, a direção dos ventos e o processo de evapotranspiração (Akbari, 1997), além da retenção de partículas e do armazenamento do carbono atmosférico (Mcpherson, 1992).

Inserir a vegetação em áreas urbanas é uma das principais estratégias para reduzir o efeito de Ilha de Calor, uma vez que as plantas representam um importante papel de regular o clima urbano (Yu, 2005). Para ser mais preciso, a vegetação reduz o efeito de Ilha de Calor não por meio do resfriamento do ar, mas pelo fato de aquecer menos o ar (Dimoundi e Nikolopoulou, 2000).

De acordo com dados do Atlas Ambiental de São Paulo (SVMA, 2000), a redução das áreas verdes em São Paulo é causada não apenas pelas ocupações ilegais do solo, por cortiços e favelas em terrenos públicos, mas também é acentuada pelo crescente processo de impermeabilização do solo por meio da construção de edifícios e novas vias públicas.

Como principais conseqüências geradas por esta redução da vegetação urbana, a SMVA (2000) aponta o problema das enchentes - que ocorrem em mais de 400 pontos na cidade, o desconforto térmico das áreas centrais, a poluição do ar - causada em sua maior parte pela circulação dos quase cinco milhões de veículos do município, o comprometimento irreversível dos mananciais - ocasionado pela ocupação desordenada, a poluição visual e sonora; etc.

A substituição das áreas verdes e permeáveis por edifícios e áreas pavimentadas resulta, dentre outros efeitos já mencionados, em alterações nos microclimas urbanos, causando, por sua vez, desconforto ambiental para os pedestres. Essas alterações são

\footnotetext{
2 "Urban canyon is defined as the three-dimensional space bounded by a street and the buildings that abut the street." (EMMANUEL, 2005, p.23)
} 
caracterizadas principalmente pelo aumento de temperatura do ar e das superfícies urbanas e, conseqüentemente, elevação do consumo de energia pelo uso dos sistemas de condicionamento ativo.

Considerando-se os materiais de uso corrente no ambiente urbano, tais como o concreto e o asfalto, estes apresentam significativas diferenças nas suas propriedades térmicas (incluindo a capacidade de absorção e transmissão de calor) e propriedades radiativas da superfície (reflexão e emissividade) quando comparados com as áreas rurais (Oke, 1982). Sendo assim, a ausência de vegetação contribui para a formação do efeito de ilha de calor, pois influencia em dois mecanismos fundamentais para a redução da temperatura nas cidades: o sombreamento e o processo de evapotranspiração (Akbari, 1997).

Além de alterar a temperatura, a vegetação também influencia na direção dos ventos, na filtragem da poluição e na proteção de pisos e fachadas externas por meio do sombreamento. Akbari (2001) identifica o uso de vegetação como sendo mais eficiente do que a substituição das superfícies por materiais de cor clara ou de alto coeficiente de reflexão, pois os materiais têm a capacidade de absorver e armazenar calor, e mesmo uma superfície de cor branca pode atingir $10^{\circ} \mathrm{C}$ acima da temperatura do ar ambiente.

Um dos principais efeitos benéficos da vegetação é a evapotranspiração, compreendendo as perdas associadas de água, que ocorrem pela evaporação da superfície do solo e pela transpiração dos estômatos ${ }^{3}$ e cuticular da planta. Sendo assim, a transpiração das plantas também ajuda no controle da temperatura e umidade do ar (Ometo, 1981).

Dessa forma, o Brasil torna-se um local potencial para o desenvolvimento de novos estudos nesta área, tendo em vista a diversidade climática do país, as atuais condições ambientais urbanas das grandes cidades, a falta de diretrizes para os projetos de arborização de vias e demais espaços públicos, e de um planejamento urbano de longo prazo, que considere estratégias para amenizar o efeito de ilha de calor, melhorando o conforto térmico do pedestre. A falta de modelos preditivos ainda limita a aplicação dos

\footnotetext{
${ }^{3}$ Os estômatos são aberturas microscópicas, localizadas em geral na parte inferior da folha, e têm como função regular a entrada e saída de gases, como o vapor d'água, $\mathrm{O}_{2}, \mathrm{CO}_{2}(\mathrm{Oke}, 1987)$.
} 
resultados obtidos em pesquisas sobre a vegetação urbana nos processos de planejamento e desenho urbano no Brasil. Assim, existe a necessidade do desenvolvimento de pesquisas que possam avaliar o potencial microclimático das áreas verdes de acordo com o clima local.

\subsection{OBJETO E OBJETIVO}

O objeto desta pesquisa são os efeitos da vegetação nas condições microclimáticas urbanas, partindo-se da premissa que a presença da vegetação influencia o microclima do seu entorno imediato. A partir de diferentes formas de distribuição das áreas verdes na cidade e com o uso de espécies locais, o objetivo é quantificar a intensidade e a distribuição espacial dos efeitos microclimáticos da vegetação, principalmente as alterações de temperatura e umidade do ar e de temperatura superficial no nível do pedestre, utilizando-se modelos de balanço de energia.

Atualmente, a carência de áreas verdes tem gerado mudança nos microclimas das grandes metrópoles e, em São Paulo, são evidentes as conseqüências geradas por esta redução da vegetação urbana: enchentes, aquecimento das superfícies urbanas, baixa qualidade do ar, além de aumentar o efeito de ilha de calor na cidade. Portanto, existe a necessidade de se desenvolver estudos preditivos que quantifiquem os efeitos da vegetação, a fim de subsidiar as atividades de planejamento e paisagismo, levando-se em consideração os microclimas locais.

Nesta pesquisa, a análise dos resultados será feita utilizando-se modelos de balanço de energia, com o auxílio de ferramentas computacionais, para que se possa simular os efeitos da vegetação sobre as condições microclimáticas no nível do pedestre.

Esperam-se como resultados a determinação da intensidade e da área de abrangência dos efeitos da vegetação urbana na redução de temperatura e no aumento da umidade do ar, com análises de diferentes arranjos espaciais para distribuição da vegetação (linear, pequenos e grandes agrupamentos).

\subsection{METODOLOGIA}

A metodologia aplicada na pesquisa foi a seguinte: 


\subsubsection{PESQUISA BIBLIOGRÁFICA E LEVANTAMENTO DE DADOS SECUNDÁRIOS}

2. Levantamento da vegetação existente na cidade de São Paulo, com dados principalmente da SVMA. O banco de dados de vegetação ${ }^{4}$, apoiado pela Fundação de Amparo à Pesquisa do Estado de São Paulo - FAPESP foi de fundamental importância nesta fase da pesquisa, com informações da flora brasileira.

3. Levantamento na Prefeitura Municipal de São Paulo dos critérios de uso e distribuição da vegetação por meio de Políticas Públicas e Planos Diretores, assim como o custo da manutenção de árvores de médio e grande porte e espécies não aconselhadas para o plantio em vias de tráfego.

4. Estudo de fisiologia vegetal e processos que influenciam na evapotranspiração das plantas, tais como a quantidade de luz, o tipo de clima e a presença de água. A disciplina BIB 7520, Anatomia Ecológica da Folha, no Departamento de Botânica do Instituto de Biociências da USP, foi fundamental na compreensão dos processos fisiológicos que ocorrem nas folhas.

5. Entendimento dos fenômenos envolvidos no balanço de energia e nas alterações no clima provocadas pela urbanização. Outros aspectos correlatos, tais como a dispersão de poluentes, também foram estudados, apesar de não fazerem parte do objetivo desta pesquisa.

6. Conhecimento do modelo ENVI-met, proposto por Bruse (1998), bem como das alterações que se fizeram necessárias para as simulações sob condições tropicais, que foram conduzidas juntamente com outros pesquisadores do Laboratório de Conforto Ambiental e Eficiência Energética, LABAUT-FAUUSP.

\subsubsection{LEVANTAMENTO DE DADOS PRIMÁRIOS}

1 Levantamento dos dados de entrada do modelo ENVI-met (dados climáticos e de vegetação local).

\footnotetext{
${ }^{4}$ Disponível em: <http://florabrasiliensis.cria.org.br〉. Acesso em julho de 2007.
} 
- Foi necessária a construção de um banco de dados de vegetação local ${ }^{5}$, a partir da pesquisa prévia das espécies mais utilizadas na cidade, com o levantamento de todas as propriedades utilizadas pelo modelo. $\mathrm{O}$ banco de dados de vegetação do ENVI-met tem como uma das principais variáveis o LAD - Leaf Area Density, isto é, uma relação entre a área de folha pela quantidade total de folhas em $1 \mathrm{~m}^{3}$ de copa, dado este de difícil quantificação e pouco conhecido nas áreas de paisagismo e mesmo da botânica. Os valores do LAD para diferentes espécies podem ser determinados de diferentes maneiras. Primeiramente, pela metodologia de Peper e McPherson (1998) com uso de imagens fotográficas para se determinar a densidade das folhas. Como alternativa, pode-se se calcular os valores médios de LAD a partir de equipamentos como o LAI-2000 Plant Canopy Analyzer, que considera a distribuição das folhas de forma aleatória, o que gera uma baixa estimativa quando as folhas estiverem mais agrupadas ou sobrepostas.

- Dados microclimáticos das regiões em estudo, baseados nos resultados de medições in loco, descritos ao longo deste trabalho.

2 Inicialmente foram feitas algumas simulações paramétricas para se investigar o efeito da distribuição de áreas verdes (linear, grandes massas verdes concentradas ou pequenos agrupamentos distribuídos em diferentes distâncias) e a extensão dos efeitos microclimáticos nas condições de temperatura e umidade do ar.
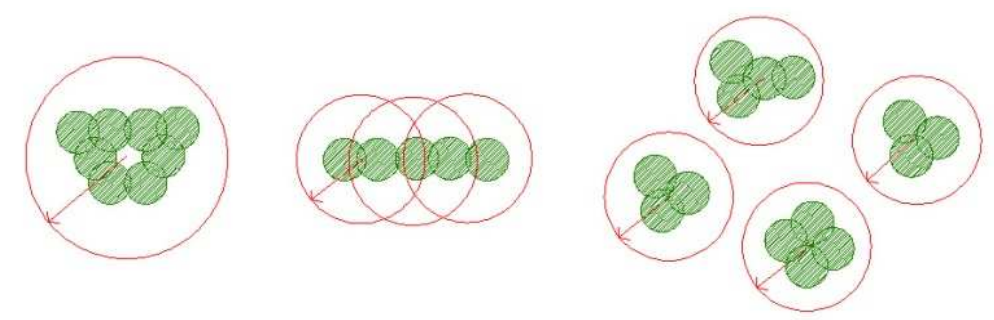

Figura 2: Propostas iniciais de distribuição da vegetação nas simulações paramétricas.

3 Foi feita a definição e o levantamento das áreas de estudo, incluindo a configuração geométrica, os materiais utilizados nas superfícies urbanas e suas características

\footnotetext{
${ }^{5}$ O Anexo 1 apresenta um quadro com as árvores mais utilizadas na cidade de São Paulo, segundo a SVMA.
} 
termofísicas e a vegetação local. Há um interesse especial nos bairros centrais na cidade de São Paulo, particularmente na região da Luz por uma série de razões. Essa área é foco de interesse do poder público para revitalização da área central de São Paulo e apresenta um parque urbano densamente arborizado, o Parque da Luz, com pouca vegetação na rua.

4 Foi feita a construção dos modelos 3D das áreas de estudo, com as especificações geométricas e características superficiais necessárias ao uso do modelo ENVI-met.

5 Foram feitas medições microclimáticas na área de estudo da Luz, no nível do pedestre, nos períodos de verão e de inverno, para alimentar as simulações computacionais no ENVI-met. Para esta etapa contou-se com o apoio da equipe do LABAUT, que já tem experiência em trabalhos de campo similares (SOUZA, DUARTE, 2004; PRATA, 2005; DUARTE, GONÇALVES, 2006), e dos equipamentos existentes no laboratório, parte deles adquiridos com recursos da FAPESP (1995/5597-5) e o processo FAPESP 02/07513-9, referente ao doutorado da Alessandra Prata.

\subsubsection{AVALIAÇÃO QUANTITATIVA DO EFEITO DA VEGETAÇÃO}

1 Primeiramente, foram realizadas simulações testes para se determinar os ajustes necessários para as condições climáticas medidas na área de estudo.

2 Em seguida, foi estruturado um modelo paramétrico de nove quadras com diferentes distribuições da vegetação e densidade dos edifícios. A configuração geométrica das quadras foi baseada em valores médios obtidos para a região de Moema.

3 Por fim, foi feita uma proposta de distribuição da vegetação na área da Luz, baseado nos resultados obtidos nas simulações anteriores. O diagrama abaixo mostra como foram organizadas as simulações no ENVI-met. 


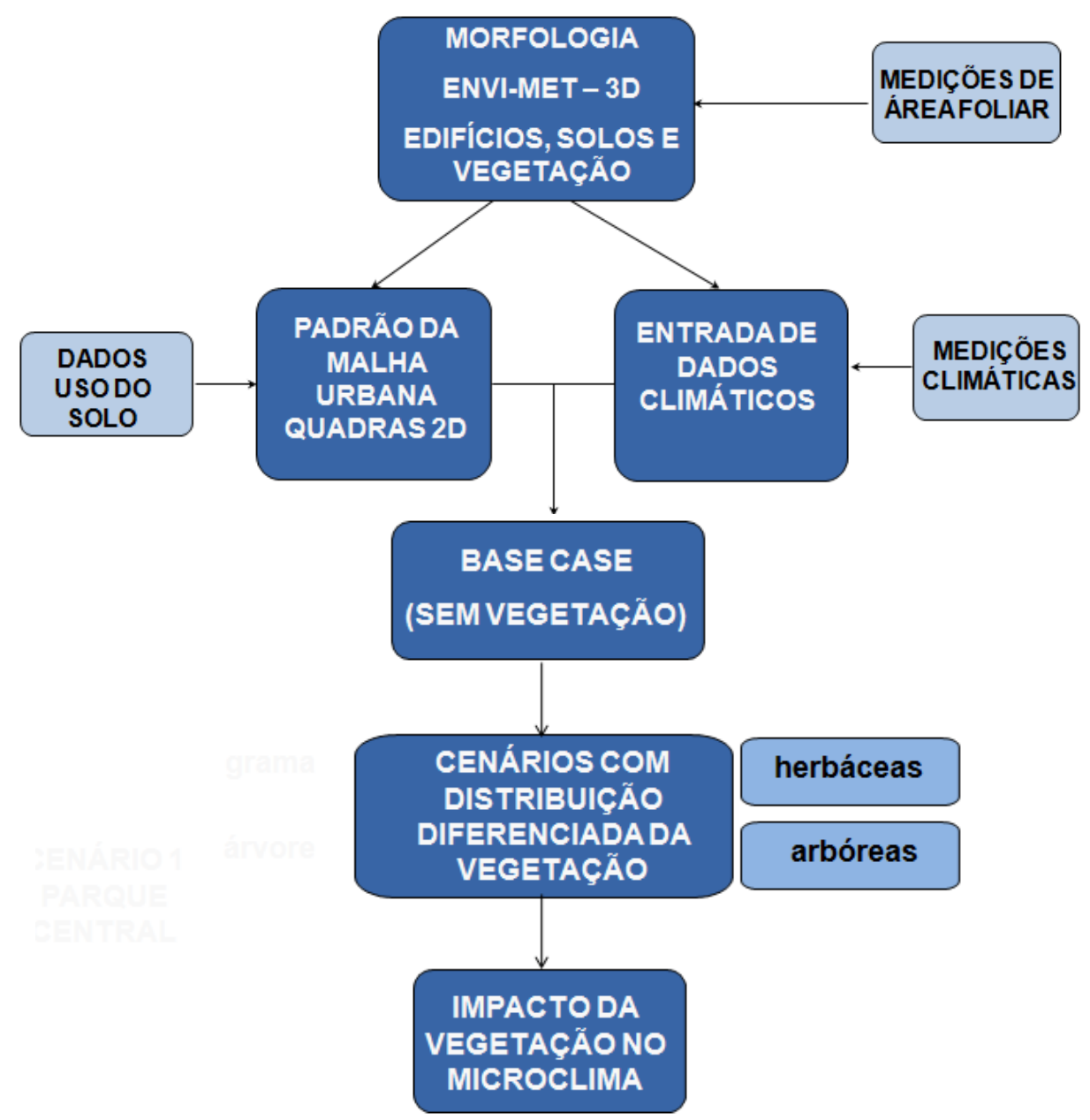

\subsubsection{ANÁLISE DOS RESULTADOS E CONCLUSÕES}

1 Análise dos resultados, usando principalmente os dados de saída de temperatura do ar, temperatura superficial e umidade do ar.

2 Recomendações para uso da vegetação urbana, visando à melhoria das condições microclimáticas, que possam servir como orientação para políticas públicas e planos diretores.

3 Conclusões.

\subsection{ESTRUTURA DA DISSERTAÇÃO}

Esta dissertação está estruturada em nove capítulos: 
- CAPÍTULO 1- Introdução e justificativa para a pesquisa: faz a introdução ao tema de pesquisa, cujos principais subitens são a justificativa, o objeto, os objetivos, a metodologia e a estrutura da dissertação. Neste capítulo está descrito o foco da pesquisa e a importância do tema para os estudos que estão sendo desenvolvido no Brasil.

- CAPÍTULO 2 - A influência da vegetação na qualidade ambiental e políticas públicas de arborização: apresenta um breve panorama dos benefícios da vegetação nas cidades em relação aos efeitos na saúde humana, no clima e no sistema ecológico. O último item mostras algumas estratégias de projeto idealizadas e/ ou implementadas por governos internacionais que utilizaram a vegetação para melhorar a qualidade do conforto térmico em áreas urbanas e as políticas públicas de arborização urbana que estão sendo aplicadas em algumas cidades brasileiras.

- CAPÍTULO 3 - O efeito da vegetação no microclima urbano e alguns modelos de cálculo mais representativos: descreve a influência da vegetação no microclima por meio de modelos de balanço de energia no nível da folha e para uma árvore adulta. Mostra os principais modelos computacionais que simulam o efeito da vegetação no microclima urbano.

- CAPÍTULO 4 - Aplicações do modelo ENVI-met nesta pesquisa: Apresenta com mais detalhes o modelo computacional ENVI-met e de que forma foi aplicado na pesquisa para avaliar a influência da vegetação urbana.

- CAPÍTUlO 5 - Medições de campo: explica os procedimentos das medições realizadas na área da Luz e os principais resultados.

- CAPÍTULO 6 - Simulações paramétricas no ENVI-met sem vegetação: mostra as simulações iniciais realizadas para ajustar os dados de entrada do programa ENVImet com as medições de campo realizadas na região da Luz.

- CAPÍTULO 7 - Simulações paramétricas no ENVI-met com vegetação: descreve as simulações paramétricas com diferentes configurações para a distribuição da vegetação e para a geometria urbana. Em seguida mostra os principais resultados da simulação na área da Luz.

- CAPÍTULO 8 - Análise dos resultados, considerações finais e conclusões: mostra a análise dos resultados, usando principalmente os dados de saída de temperatura do 
ar e superficial das simulações realizadas. Apresenta a conclusão da pesquisa com recomendações para uso da vegetação urbana, visando à melhoria das condições microclimáticas, que possam servir como orientação para políticas públicas e planos diretores e as considerações finais.

- CAPÍTUlO 9 - Referências Bibliográficas: indica a bibliografia referenciada e consultada durante a pesquisa. 


\section{A INFLUÊNCIA DA VEGETAÇÃO NA QUALIDADE} AMBIENTAL URBANA E POLÍticas PUBLICAS DE ARBORIZAÇÃO

\subsection{INTRODUÇÃO AOS BENEFÍCIOS DA VEGETAÇÃO}

Os benefícios da vegetação podem ser organizados segundo quatro aspectos:

1. Influência sobre os aspectos climáticos: melhoria do microclima entre os edifícios, em relação à qualidade do ar, sombreamento nos climas quentes, proteção aos ventos no inverno e contribuição para orientar a ventilação natural.

2. Influência sobre os aspectos ecológicos relacionados à água: contribuição no controle de enchentes, proteção contra a erosão do solo, ajuda na retenção e absorção das águas da chuva. Serve também como base para implantar a infraestrutura dos sistemas públicos de água e esgoto.

3. Influência sobre os aspectos da vida humana: utilização em lugares como playground, áreas de esportes e recreação para criar um ambiente agradável, facilitando o encontro das pessoas. Cria caminhos de passagem para pedestres e determina a divisão de áreas com usos diferenciados. Ajuda na recuperação de pacientes em hospitais e na diminuição dos índices de violência, além de valorizar imóveis próximos às áreas verdes.

4. Influência sobre os aspectos relacionados à fauna: habitat, diversidade e proteção natural da fauna.

\subsubsection{ASPECTOS CLIMÁTICOS}

Um dos efeitos da vegetação é o resfriamento do ar por meio do aumento da umidade proveniente do processo de evapotranspiração (Dimoundi e Nikolopoulou, 2003). A evaporação depende da refletância, da morfologia, da rugosidade e da resistência da superfície da folha (Mascaró, 1998). A influência da vegetação no microclima depende também da sua densidade de copa (Geiger, 1961).

Em áreas de clima subtropical a umidade relativa do ar em áreas abaixo da vegetação foi de 3-10\% maior que nas áreas sem vegetação. A grande diferença ocorre no verão porque o efeito é proporcional à densidade das folhas. Um resultado inferior ocorreu 
durante a primavera, devido à presença de vento e existência de espaços vazios na copa das árvores (Mascaró, 1998).

Sobre a qualidade do ar, Nowak (2004) cita a função das árvores em remover partículas poluentes por meio das aberturas dos estômatos. Os gases poluídos são dissolvidos nos espaços intercelulares e podem ser absorvidos para gerar ácidos ou reagir com as superfícies internas da folha.

As árvores também removem temporariamente os poluentes ao reter as partículas na superfície da folha, podendo estas ou retornar à atmosfera, ou serem levadas pelas águas da chuva ou ainda ficarem incorporadas ao solo quando a folha se desprender.

Em 1994, as florestas urbanas da cidade de Nova Iorque obtiveram excelentes resultados ao remover cerca de 1.821 toneladas de ar poluído com um investimento de US\$9.5 milhões. Em outras cidades como Atlanta e Baltimore, as árvores retiraram 1.196 e 499 toneladas de ar poluído, respectivamente (Nowak, 1994).

Nestes estudos foi observado que a capacidade de remoção da poluição pelas árvores depende da quantidade de poluentes na atmosfera, dos tipos de folhas, dos períodos de chuva e de outras condições climáticas. Em geral, uma árvore saudável de $77 \mathrm{~cm}$ de diâmetro de tronco remove setenta vezes mais de partículas poluentes $(1,4 \mathrm{Kg} / \mathrm{ano})$ do que uma árvore jovem de $8 \mathrm{~cm}$ de diâmetro (0,02 Kg/ ano), segundo Nowak (1994).

Outra característica das plantas é a emissão de compostos orgânicos voláteis (VOCs ${ }^{6}$ ) que favorecem a formação do ozônio e do monóxido de carbono. Estima-se que as emissões de VOCs pela vegetação são comparáveis, ou excedem as emissões de VOCs de fontes antropogênicas ${ }^{7}$, em escala regional e global (Guenther, 1999 apud Souza et al., 2002).

Apesar das plantas contribuírem com parte dos hidrocarbonetos que formam o ozônio $\left(\mathrm{O}_{3}\right)$, não se pode considerar a vegetação nociva, pois os automóveis, além de emitirem esses gases, também lançam os óxidos de nitrogênio $\left(\mathrm{NO}\right.$ e $\mathrm{NO}_{2}$ ) necessários para a

\footnotetext{
${ }^{6}$ Volatile Organic Compounds - compostos orgânicos voláteis.

7 O calor antropogênico gerado por meio de atividades humanas utiliza hidrocarbonetos como combustíveis fósseis e influenciam na formação das ilhas de calor nas cidades (Voogt, 2004).
} 
reação do $\mathrm{O}_{3}$. Numa floresta, por exemplo, os níveis de $\mathrm{O}_{3}$ são realmente baixos (Martins, 2007 apud Telles, 2003).

Além das árvores absorverem o carbono, estocando-o na sua estrutura durante o crescimento, as plantas também removem substâncias contaminantes como formaldeído, benzina e tricloroetileno em espaços internos. O formaldeído aparece nas espumas de isolamento, na madeira compensada, nas roupas, nos carpetes, nos móveis e nos produtos de limpeza. A benzina está presente em fibras sintéticas, na fumaça de cigarro, no plástico, nas tintas, nos detergentes e nas borrachas. $\mathrm{O}$ tricloroetileno aparece nos adesivos, nas tintas de parede e nos produtos de limpeza (Yeang, 1999).

Voogt (2004) destaca a importância de se plantar árvores no entorno dos edifícios para proteger as fachadas por meio do sombreamento. A redução na temperatura de superfície das paredes protegidas pela vegetação tem uma influência na temperatura interna do edifício, proporcionando uma redução no uso dos sistemas artificiais de condicionamento do ar. As árvores também podem ser utilizadas no sombreamento de vias e estacionamentos evitando o aquecimento excessivo de materiais como asfalto e concreto e a liberação do calor acumulado durante a noite.

O efeito do sombreamento pelas árvores também mostra resultados significativos na redução dos sistemas de ar condicionado. Ao longo da vida da árvore, os benefícios trazidos pela redução do uso de ar condicionado e pela diminuição da temperatura do ar variam de acordo com o clima da região, mas tem um potencial na economia de energia que chega a US\$200 por árvore. Considerando-se o custo do plantio e manutenção de US\$10 a US\$500 por árvore, os programas sociais que envolvem a comunidade são uma das estratégias para reduzir os custos do investimento (Akbari, 2005).

Os efeitos diretos do sombreamento pela vegetação podem ser quantificados por meio das medições da temperatura de superfície de materiais expostos e protegidos pelas copas das árvores (figura 3). 


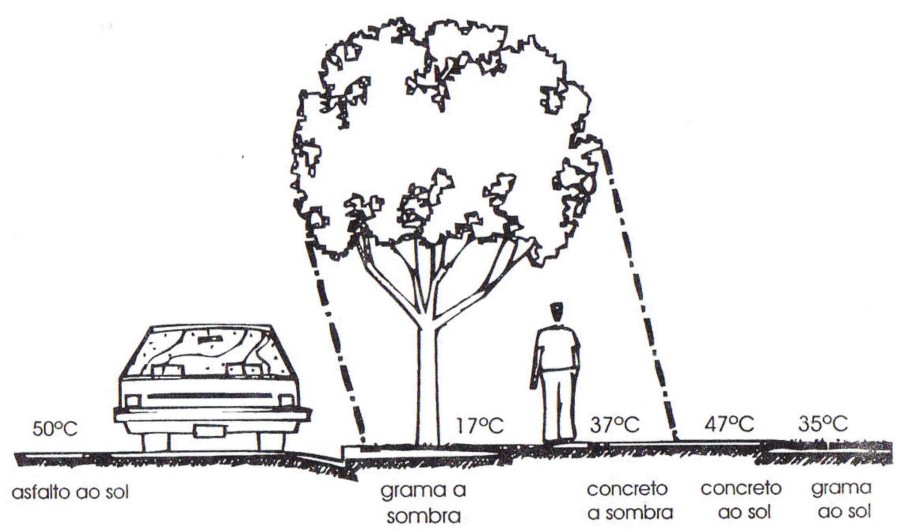

Figura 3: Temperatura de Superfície por meio do sombreamento das árvores.

Fonte: Laurie (1878) apud Mascaró (2005).

Segundo Heisler (1986), as árvores influenciam diretamente o fluxo de calor da radiação térmica ao bloquear a radiação solar, evitando o aumento da temperatura da superfície. Em seus estudos, a posição das árvores é determinante para oferecer um sombreamento adequado e reduzir a radiação direta que chega aos edifícios. Experiências sobre o efeito da sombra de uma árvore foram analisadas para as situações de fachada oeste e sul, na latitude $40^{\circ}$ (Figura 4).

Concluiu-se neste estudo que o efeito do sombreamento não necessariamente reduz o consumo de energia, pois a eficiência é determinada por um posicionamento estratégico das árvores que combine três condições: proteção das fachadas no verão para evitar o uso de ar condicionado, bloqueio dos ventos frios e diminuição das sombras no inverno.



Figura 4: Estudos do sombreamento das árvores na fachada oeste e sul para os períodos de verão e inverno.

Fonte: Heisler (1986). 
Mascaró (2005) cita os quatros efeitos básicos da vegetação em relação ao vento, a partir dos trabalhos de Robinete (1972): a canalização, a deflexão, a obstrução e a filtragem. A canalização dos ventos ocorre quando existe um corredor de árvores bem definido e de pequena largura (menor que 2.5 vezes a altura média) e, em geral, este fenômeno intensifica a velocidade dos ventos que podem atingir $3,5 \mathrm{~m} / \mathrm{s}$.

A deflexão influencia a mudança de trajetória do vento, variando a orientação e velocidade conforme a distribuição da vegetação. A obstrução acontece quando as árvores formam uma barreira para a passagem do vento e, segundo Mascaró (2005), as barreiras de vegetação são mais eficazes do que as barreiras sólidas, pois a redução da velocidade é gradual e evita as zonas de turbulência, devido à permeabilidade da copa.

Por fim, a filtragem serve para reduzir a velocidade dos ventos e barrar a poeira e outros resíduos transportados. Em termos estéticos, proporciona privacidade e a divisão dos espaços em áreas públicas.

Os estudos de Heisler (1989) apud Santamouris (2001) indicam que o aumento de 10\% no número de árvores representa uma redução de $10 \%$ a $20 \%$ na velocidade dos ventos para uma área residencial, enquanto que aumentando a cobertura vegetal em 30\%, os resultados serão ventos com intensidades menores em $15 \%$ a $35 \%$.

O Gráfico 1 mostra o padrão verificado na redução da velocidade dos ventos quando existe uma barreira de árvores com diferentes densidades de copas (Heisler, 1986). Neste caso, ao passar por um grupo de árvores com copas muito pouco densas, a velocidade dos ventos diminui em até $40 \%$ e a velocidade inicial é retomada a uma distância de 20 vezes a altura das árvores. Por outro lado, em copas muito densas, a velocidade pode ser reduzida em $75 \%$ e o efeito da barreira estende-se a uma distância de 30 vezes a altura das árvores.

Este estudo mostra que a proteção varia entre 10 a 20 vezes a altura das árvores, mostrando que as mudas não precisam ser plantadas próximas aos edifícios e residências para diminuir os ventos no inverno. Porém, em áreas urbanas, a concentração de edifícios causa turbulência nos ventos antes de passar pelas árvores, resultando em valores menores do que os apresentados na Figura 5 (Heisler, 1986). 
Kuhns (2008) sugere que árvores com copas estreitas sejam plantadas a uma distância de 1.2 metros em relação às construções enquanto, árvores de copa larga (Figura 6) fiquem a uma distância de 2.5 metros (100 polegadas) para reduzir os ventos de $15 \mathrm{~m} / \mathrm{s}$ (35 m.p.h.) para $4.5 \mathrm{~m} / \mathrm{s}$ (10 m.p.h.).

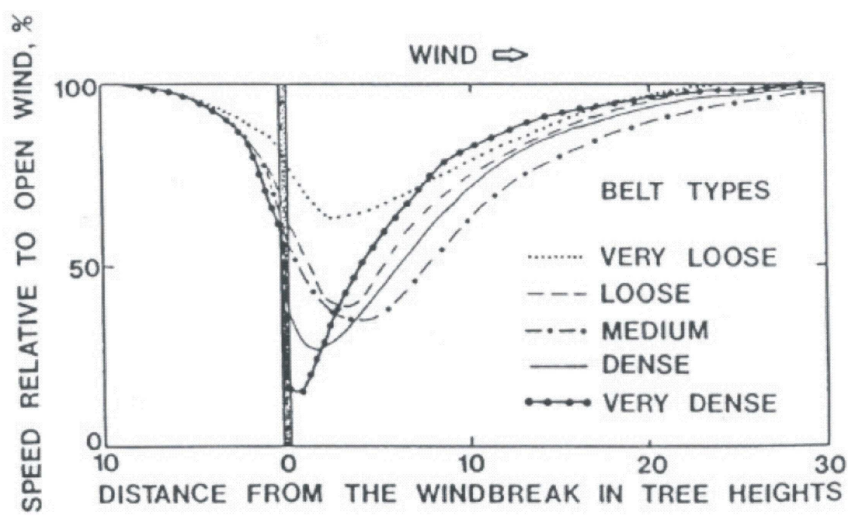

Figura 5: A redução da velocidade dos ventos $(\%)$ em relação à distância do grupo de árvores com diferentes densidades das copas (distância de acordo com a altura das árvores) .

Fonte: Heisler (1986).

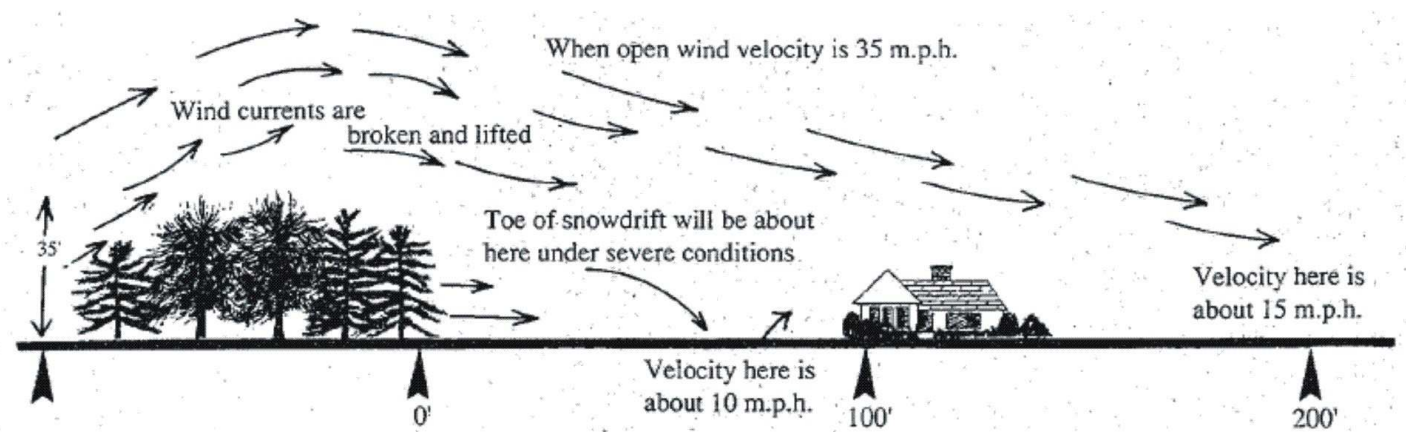

Figura 6: Efeito das árvores na velocidade dos ventos.

Fonte: Kuhns (2008). Disponível em:

<http://extension.usu.edu/forestry/HomeTown/Energy_TreesandEnergy.htm >. Acesso em abril de 2008.

Dentro de certos limites, a vegetação pode ser utilizada com um atenuador (buffer) de ruídos urbanos (Givoni, 1991). Porém, a colocação de árvores em estradas e rodovias não funciona como barreira acústica para o ruído linear urbano gerado pelos veículos, pois a copa, mesmo sendo muito densa, é um material poroso, permitindo a passagem de vento e do som. Apesar das plantas absorverem melhor o som de alta freqüência, os ruídos urbanos causados por veículos são de baixa frequiência (até $300 \mathrm{~Hz}$ ) e, portanto, mais difíceis de se mascarar porque têm ondas de grandes amplitudes. 
A forma mais eficiente de se utilizar a vegetação como barreira acústica é associá-la com um material sólido. Nas laterais das estradas podem-se criar inclinações no terreno, revestidos com plantas e grama. Assim, o ruído não atravessa a barreira acústica, sendo refletido para outras áreas.

\subsubsection{ASPECTOS ECOLÓGICOS RELACIONADOS À ÁGUA}

A Agência Americana de Proteção Ambiental (EPA, 2003) explica que uma das consequiências da diminuição de áreas permeáveis na cidade é o aumento da velocidade das águas da chuva, podendo a velocidade de escoamento num quarteirão ser cinco vezes maior do que em áreas de mesmo tamanho com vegetação e solo aberto.

A figura 7 mostra a relação entre áreas com vegetação e superfícies impermeáveis, sendo que a falta de infiltração pelo solo aumenta a quantidade e a velocidade das águas que chegam aos córregos e rios em até 45\% (EPA, 2003).
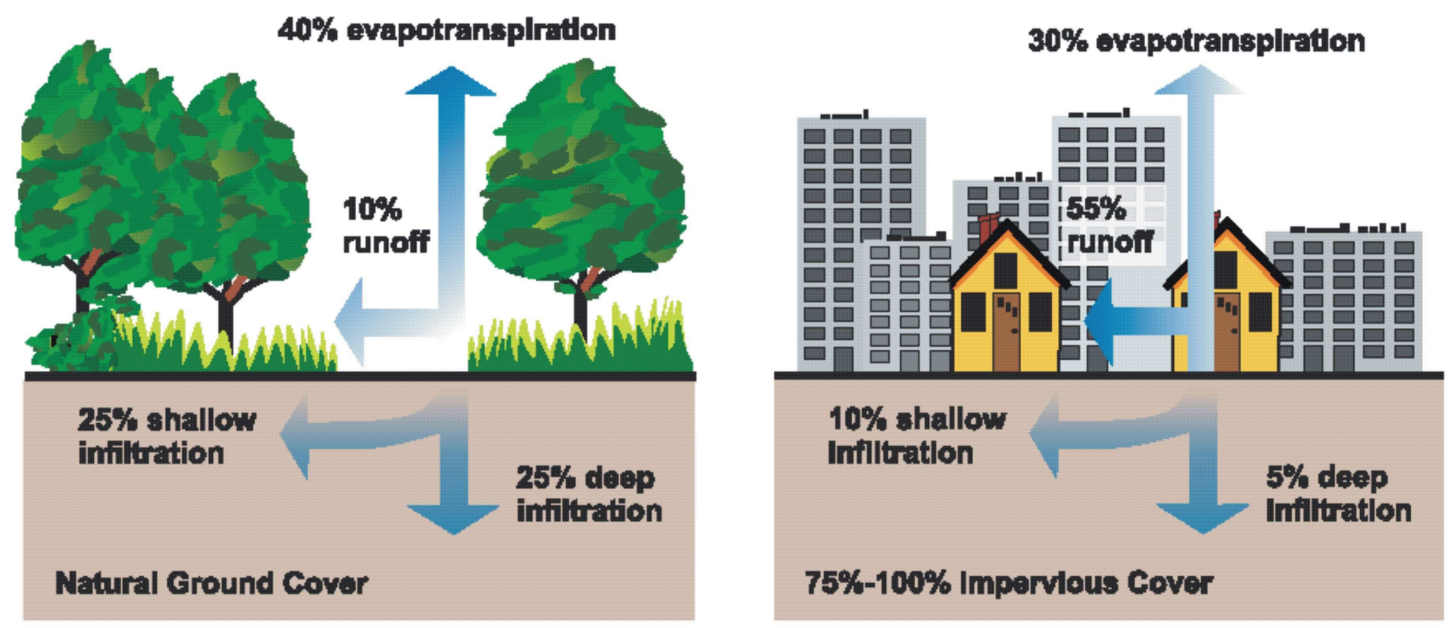

Figura 7: Relação entre pavimento impermeável e escoamento das águas da chuva.

Fonte: EPA - Agência de Proteção Ambiental

Disponível em: < http://www.eustis.org/npdes/Urbanfacts.pdf $>$ Acesso em outubro de 2007.

A maior velocidade das águas em superfícies como asfalto e concreto contribui para o transporte de lixo, de sedimentos, de óleos, de restos de construção para o sistema público de coleta de água, chegando a entupir bocas de lobo e bueiros.

No Brasil, a maioria dos alagamentos não é mais por conta dos córregos, como ocorre na região do Pirajussara, do Ribeirão dos Couros, do Tamanduateí ou do Aricanduva, na 
cidade de São Paulo. As enchentes acontecem em muitos casos em consequiência da impermeabilização de $80 \%$ dos $1500 \mathrm{~km}^{2}$ da cidade pois, sem terra no solo, a água corre mais rápido e com mais intensidade para os bueiros, transbordando as galerias (Carvalho, 2007).

Os "piscinões" são estruturas utilizadas na cidade de São Paulo para armazenar parte das águas e liberá-las para os rios depois do pico das chuvas. No entanto, estes elementos não são suficientes para conter a quantidade de chuvas, necessitando de novas estratégias de drenagem natural das águas que considerem a proporção das áreas impermeáveis e vegetadas, a intensidade e a duração das chuvas, e o tipo do solo com taxa adequada de porosidade. Sobre este último item, a Tabela 1 indica diferentes materiais utilizado nas cidades e o grau de impermeabilidade.

Tabela 1: Grau de Impermeabilidade dos Materiais.

\begin{tabular}{|c|c|}
\hline Asfalto e concreto & 1.00 \\
\hline Cobertura com cascalho & 0.80 \\
\hline Pavimento com juntas largas & 0.70 \\
\hline Pavimento em mosaico com juntas largas & 0.60 \\
\hline Pavimento com concerto e grama & 0.30 \\
\hline Coberturas verdes & 0.30 \\
\hline Gramado & 0.25 \\
\hline Áreas verdes & 0.10 \\
\hline Fonte: Borke (2006).
\end{tabular}

Fonte: Borcke (2006).

Segundo Borcke (2006), existem diferentes sistemas de retenção das águas que podem estar implantados em pequena escala, dentro de terrenos privados, ou em grandes empreendimentos públicos com um sistema interconectado de coleta das chuvas. Entre os exemplos, são citadas as seguintes estruturas (Figura 8): área de drenagem mais baixa (low área drain), fossos e valetas (ditches and wales), lagos de retenção permanente (permanent retention pounds) e cisternas de coleta subterrânea (underground collection cisterns). 

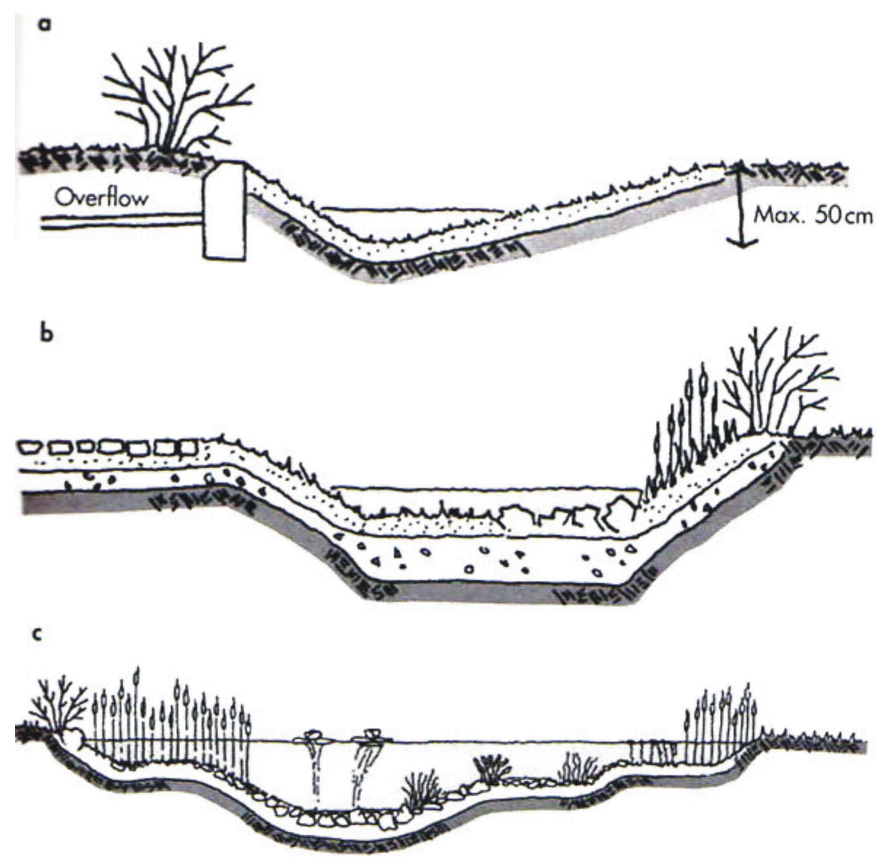

d

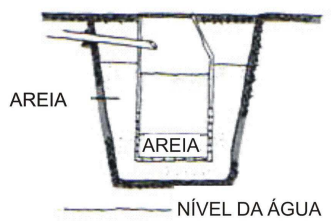

Figura 8: Diferentes sistemas para retenção das águas: a) área de drenagem mais baixa, b) fossos e valetas, c) lagos de retenção permanente, d) cisternas de coleta subterrânea.

Fonte: Borcke (2006).

Além de ajudar a drenar as águas da chuva, a vegetação impede a degradação do solo por meio da erosão. Estima-se que um sexto do solo mundial já foi degradado pela erosão da água e vento, causando a perda da sua qualidade e impactos na agricultura e no ambiente natural (Favis-Mortlock et al., 1996).

A erosão hídrica é das formas mais sérias de destruição do solo, pois, além de reduzir a capacidade produtiva, causa prejuízos financeiros e ambientais em razão da perda de nutrientes como potássio, cálcio e magnésio. A concentração destes nutrientes na enxurrada da erosão hídrica depende da quantidade existente na camada mais superficial do solo e significa uma perda monetária quando os adubos e calcários adicionados ao solo são levados na erosão (Bertol et al., 2007).

Nos Estados Unidos, aproximadamente 4 bilhões de toneladas de solo e 130 bilhões de toneladas de água são perdidas anualmente, representando um prejuízo de US\$ 27 
bilhões a cada ano, sendo US\$ 20 bilhões para repor os nutrientes e US\$ 7 bilhões para perda de água e aumento da profundidade do solo (Pimentel et al., 1995).

Uma solução para estes casos é o uso da vegetação. As árvores são essenciais para evitar o escoamento acelerado das águas da chuva, servindo de barreira para os ventos e mantendo o solo estável com as raízes. A Tabela 2 indica restrições para os terrenos com declividade acentuada, mostrando que, em inclinações maiores de 30\%, a estabilização do terreno deve ser feita por meio de vegetação.

Tabela 2: Restrições de uso de terrenos com declividade acentuada.

\begin{tabular}{|c|l|}
\hline Declividade (\%) & \multicolumn{1}{c|}{ Limitações de Uso } \\
\hline Até 7 & Pedestres circulam com conforto. \\
\hline Até 8 & $\begin{array}{l}\text { A rega da grama pode ser feita por aspersão, sem perder água por } \\
\text { escorrimento. }\end{array}$ \\
\hline Até 15 & Pedestres podem transitar pela grama sem criar problemas. \\
\hline Até 30 & É possível cortar a grama com máquinas especiais \\
\hline$>30$ & O terreno poderá ser estabilizado só com a ajuda de vegetação. \\
\hline
\end{tabular}

Fonte: Mascaró (1991).

\subsubsection{ASPECTOS DA VIDA HUMANA}

As árvores têm um importante papel social. Proporcionam áreas de integração entre as pessoas, favorecendo o contato social e atividades culturais (Givoni, 1991). Estudos da Universidade do Texas mostram que áreas verdes ajudam na qualidade da saúde das pessoas, abaixando a pressão sanguínea, contribuindo para uma atividade mais relaxada das ondas cerebrais e para a redução dos batimentos cardíacos. Ajudam também na recuperação de pacientes em hospitais por meio dos "jardins de cura" (healing gardens), cuja função é reduzir o estresse, a ansiedade e a depressão, facilitando o tratamento e ajudando na diminuição da quantidade de medicamentos (Ulrich, 2003).

Os pesquisadores Kuo e Sullivan (1998) da Universidade de Illinois, Estados Unidos, desenvolvem pesquisas relacionando o comportamento humano e o meio ambiente. Em seus estudos, eles mostram a importância da vegetação para diminuir os índices de violência nos bairros americanos e melhorar a qualidade do espaço. 
Os autores acreditam que a proximidade com áreas verdes reduz a fadiga mental e conseqüentemente, diminui a agressividade entres os moradores, gerando ambientes familiares mais seguros. Os resultados da pesquisa $^{8}$ influenciaram novas políticas públicas, nas quais foram investidos US\$10 milhões no plantio de 20.000 árvores na cidade de Chicago (Prow, 1999).

A presença de árvores também aumenta o valor das propriedades (Santamouris, 2001). Nas cidades de Emmen, Appledoorn e Leiden, na Holanda, edifícios com vista para um parque aumentaram o valor dos apartamentos em $8 \%$ e a proximidade com uma área verde valoriza a propriedade em 6\%. Da mesma forma, a vista para um lago ou a proximidade com um espelho d'água valoriza a residência em 10\% e 7\%, respectivamente. Por outro lado, a vista para um outro edifício desvaloriza a propriedade em $7 \%$ (Luttik, 2000).

Nos estudos de Taha e Akbari (1992), o valor econômico das residências aumentou entre 3\% e 20\% (Santamouris, 2001). Em Berlim, as áreas residenciais próximas a locais de lazer, como playground, tiveram o valor da terra aumentado em 16\%; já as propriedades com áreas verdes no entorno tiveram um acréscimo de 17\% (Phillips, 2000).

\subsubsection{ASPECTOS RELACIONADOS À FAUNA}

A vegetação promove a integração entre o meio natural e construído, contribuindo, dessa forma, para a manutenção da diversidade genética de espécies animais e vegetais (Forman e Godron, 1986).

As plantas são fontes de comida e habitat para muitas espécies de animais como insetos, pássaros e pequenos mamíferos. Assim, a diversidade das espécies nativas é determinante para se atrair diferentes tipos de animais e a combinação das plantas depende do tipo de solo, da quantidade de água disponível e do clima existente (Borcke, 2006).

\footnotetext{
${ }^{8}$ Relatório "Cooler in Shade", Human-Environment Research Laboratory, Universidade de Illinois, disponível em: 〈http://www.projectevergreen.com/pdf/Technical\%20Bulletin.pdf〉. Acesso em setembo de 2007.
} 
Na Europa, foi criado o projeto Natura $2000^{9}$ pela European Commission, e apoiado pela Eurosite, The European Landowners Organization e EUROPARC Federation, buscando apontar as melhores práticas para manutenção das reservas naturais e habitat da fauna silvestre.

Em São Paulo, preocupados em oferecer um tratamento adequado para as espécies de animais silvestres, a Secretaria do Verde e Meio Ambiente criou a Divisão Técnica de Medicina Veterinária e Biologia da Fauna ${ }^{10}$ - DEPAVE 3, voltado para o cuidado e proteção da fauna existente nos parques da cidade.

O DEPAVE 3 oferece suporte técnico e ajuda no levantamento da fauna em áreas verdes no Município de São Paulo. O estudo de 35 áreas mostrou uma variedade de 294 espécies e os dados estão organizados em um sistema informatizado chamado SISFAUNA. Entre as principais publicações do DEPAVE -3 está o Guia das Aves do Parque Ibirapuera, apresentando 135 espécies de aves identificadas, incluindo as ameaçadas de extinção, endêmicas e migratórias.

\subsection{POLÍTICAS PÚBLICAS DE ARBORIZAÇÃO URBANA}

Considerando-se os benefícios apresentados anteriormente, observa-se a necessidade de implantar novas áreas verdes nas cidades para melhorar a qualidade ambiental dos espaços urbanos. Por outro lado, não basta apenas o plantio de novas mudas, deve-se estabelecer critérios para a disposição correta das árvores para maximizar os seus efeitos positivos.

A necessidade de um planejamento das áreas verdes implica em um estudo mais detalhado das condições da vegetação e sua distribuição na cidade. Assim, algumas cidades americanas, européias, asiáticas e brasileiras, conscientes da importância da arborização para a melhoria da qualidade de vida dos moradores, estão desenvolvendo políticas públicas que proporcionem um manejo adequado das árvores (poda, irrigação, adubação) e a avaliação dos benefícios trazidos pelos estudos da floresta urbana (drenagem das águas, qualidade do ar, melhoria do microclima).

\footnotetext{
${ }^{9}$ Disponível em: < http://www.natura.org/ >.Acesso em fevereiro de 2008.

${ }^{10}$ Depave 3. Disponível em: < http://www.prodam.sp.gov.br/svma/parques/medicina.htm >. Acesso em abril de 2008.
} 
O processo de urbanização mudou a relação entre a sociedade e o ambiente natural (Konijnenjijk, 2000). No século XX, o crescimento das metrópoles reduziu os espaços para as áreas verdes e o ambiente urbano criou vários obstáculos para o plantio de novas mudas como, por exemplo, a compactação do solo, o pouco espaço para o crescimento das raízes, as instalações da rede elétrica e a falta do manejo adequado das árvores (Pauleit, et al., 2002). Na cidade de Liverpool, foi monitorado o crescimento de um grupo de árvores recém plantadas e observou-se que 39\% do total de mudas morriam nos primeiros cinco anos (Gilbertson e Bradshaw, 1990 apud Pauleit, et al., 2002).

As mudanças na sociedade e no ambiente urbano resultaram em alterações na estrutura das áreas de florestas. Em resposta ao processo de urbanização, uma nova abordagem sobre a vegetação nas cidades surge com o conceito de florestamento urbano, Urban Forestry, criado nos Estados Unidos, durante a década de 1960, como um meio de administrar os recursos naturais e oferecer melhores cuidados na preservação das espécies arbóreas. Na Europa, apenas no início dos anos 1990, o conceito de floresta urbana foi incorporado como parte do processo de planejamento urbano e manejo das árvores nas cidades (Konijnenjijk, 2003).

Segundo Miller (1997), florestamento urbano é o manejo das árvores que contribuem para o bem-estar psicológico, sociológico e econômico da sociedade. Fazem parte as florestas, os grupos de árvores ou mesmo um único indivíduo arbóreo, existindo dentro ou próximo às cidades, e em variados locais como ruas, parques e esquinas. Proporciona diversos benefícios (qualidade do ar, absorção das águas, sombreamento) e alguns problemas (destruição das calçadas, queda de galhos).

Uma característica que se destaca nas pesquisas americanas é a preocupação em se quantificar os benefícios gerados pelas árvores e comparar com os custos de manutenção das áreas verdes. A partir dos resultados positivos do custo-benefício da vegetação, houve um grande incentivo por parte das agências e órgãos públicos para a criação de programas de plantio e planejamentos das novas áreas. 
No processo dos estudos dos benefícios das árvores, o San Francisco Board of Supervisors $^{11}$ (2001) realizou uma pesquisa sobre os programas de arborização urbana implementados pelas principais cidades americanas e indicou seis aspectos necessários para o sucesso das propostas:

1. Muitas cidades como Claremont, Modesto e Nova Iorque têm uma agência responsável em gerenciar apenas a conservação das árvores em parques e ruas. Em outras cidades como Los Angeles e Seattle, existem grupos específicos para coordenar os projetos entre diferentes departamentos e facilitar a administração dos programas.

2. Em geral, as verbas necessárias para os programas de arborização e pesquisa são complementados com os recursos provenientes de associações e ONGs ligadas à Prefeitura. Somente a cidade de Seattle consegue financiar os programas sem precisar de ajuda financeira de outras instituições.

3. Algumas cidades como Claremont e Los Angeles criaram um comitê (Advisory Committee) para os assuntos de políticas públicas para as árvores, ajudando na tomada de decisões para promover a melhoria da qualidade das áreas verdes públicas. As cidades sem um comitê próprio tendem a fortalecer as parcerias com entidades privadas e associações de bairro como, por exemplo, em Modesto, Milwaukee e Nova Iorque.

4. Todas as principais cidades americanas desenvolveram um banco de dados sobre a situação de cada área verde com mapeamento das espécies. Os inventários das árvores incluem tipo da espécie, idade, características históricas, tamanho de copa, solo e condição do local. Estas informações ajudaram na manutenção das árvores e definição de cuidados específicos para determinadas áreas. Em São Francisco existe uma base de dados para todas as árvores na vias públicas e outra para as árvores nos parques acima de um determinado diâmetro e altura.

\footnotetext{
${ }^{11}$ Legislative Analyst Report (2001). Disponível em: <http://www.sfgov.org/site/uploadedfiles/bdsupvrs/leganalyst/021-00_Tree\%20_Programs.pdf >. Acesso em março de 2008.
} 
5. A maioria dos municípios tem um conjunto de políticas públicas para organizar os procedimentos de manejo da floresta urbana. Estas leis contêm as responsabilidades dos donos das propriedades em relação à manutenção das árvores.

6. O ciclo regular de manutenção das árvores está presente em todas as cidades, com a exceção de Claremont e Seattle, onde se realizam os serviços conforme os pedidos dos moradores.

7. Além disso, cada programa municipal tem características próprias para incentivar o plantio de novas árvores. Nova Iorque lançou o programa One Stop Capital Shop em que os moradores podem requisitar o plantio por telefone; Los Angeles oferece o programa Adopt-a-Median, incentivando a população a cuidar dos canteiros centrais. A cidade de Chicago tem investido no Programa Green Roofs para coleta e redução da velocidade das águas da chuva e Seattle desenvolveu o Programa Tree Stewards, que proporciona o treinamento de voluntários para a manutenção das árvores.

As políticas européias vêm mudando desde a década de 1990 com uma conscientização cada vez maior na importância de se preservar e melhorar as áreas verdes na cidade. Porém, as pesquisas sobre a floresta urbana se voltam para os estudos relacionados aos benefícios na qualidade de vida dos habitantes, tais como a influência dos parques na saúde e bem-estar das pessoas (Douglas, 2005; Ulrich et al., 199; Grahn, 1994). Existe também uma tendência de se utilizar a vegetação para requalificação de antigos espaços industriais e proporcionar áreas de recreação para os moradores, com ocorre na cidade de Malmö, na Suécia.

Em comparação com os aspectos apresentados pelo San Francisco Board of Supervisors, percebe-se que existe uma estrutura clara de como são desenvolvidas as políticas norte-americanas. Entre os itens, o que mais se aproxima das atividades européias é a criação de instituições que apóiam o desenvolvimento das áreas verdes nas cidades, podendo ser financiadas pela comunidade européia ou pelos próprios governos. Por outro lado, o desenvolvimento das políticas não segue um padrão entre as cidades européias. Segundo Carter (1995), apesar da longa trajetória européia, o conceito de floresta urbana somente foi incorporado ao planejamento urbano a partir da década de 
1970, quando houve um interesse em se desenvolver novas funções estratégicas para as áreas verdes por meio da ecologia urbana (Urban Ecology) e da estrutura verde urbana (Urban Green Infra-Structure).

A partir da década de 1990, os países europeus decidiram rever o planejamento das áreas verdes, iniciando as pesquisas sobre a floresta urbana. O Comitê Forest Research Cooperation - SNS organizou o primeiro workshop sobre floresta urbana entre os países escandinavos e bálticos. A ONG European Forest Institute - EFI desenvolve pesquisas sobre áreas verdes, estabelecendo estudos comparativos sobre políticas públicas, conservação e manutenção da vegetação entre os países europeus.

Em 1997, o instituto Danish Forest and Landscape Research coordenou o Projeto European Cooperation in the Field of Scientific and Technical Research - COST, financiado pela União Européia. Um dos temas abordados foi a "Floresta Urbana e Árvores" no subgrupo COST Action E12, reunindo 100 especialistas de 22 países, no intuito de estabelecer o status das pesquisas e práticas adotadas no planejamento das áreas verdes.

Em 2001, as pesquisas desenvolvidas no Projeto COST resultaram em novas iniciativas como a criação do Centro European Urban Forestry and Information Research ${ }^{12}$ EUFORIC. Este instituto tem como objetivo coordenar e promover pesquisas sobre Floresta Urbana na Europa, além de desenvolver práticas com aplicações nas políticas públicas e educação. Organiza eventos para divulgação dos resultados das pesquisas por meio de conferências como a Forestry Serving Urbanised Societies, em 2002, e a publicação de artigos científicos no Urban Forestry and Urban Greening Journal ${ }^{13}$.

Nos centros urbanos da Alemanha e Reino Unido existe uma cobrança da própria sociedade para o planejamento e melhoria das áreas verdes e, conseqüentemente, foi organizado um conjunto de políticas públicas e programas para incentivar a arborização urbana.

\footnotetext{
${ }^{12}$ EUFORIC. Disponível em: < http://www.sl.kvl.dk/euforic/ >. Acesso em março de 2008.

13 Disponível em: <http://www.elsevier.com/wps/find/journaldescription.cws home/701803/description >. Acesso em março de 2008.
} 
A Alemanha tem uma das mais desenvolvidas infra-estruturas verdes na Europa. Destacam-se as cidades de Munique e Hannover pelos avanços nas estratégias de proteção ambiental e leis que definem parques e áreas verdes (Nilsson e Radrup, 1997).

Apesar de existirem poucas pesquisas sobre o custo-benefício das árvores em cidades européias, o UK National Urban Forestry Unit - NUFU criou o Programa ReLeaf ${ }^{14}$ para realizar estudos que quantifiquem os impactos da vegetação, utilizando o modelo computacional CITYgreen ${ }^{15}$, desenvolvido pela American Forest.

Em países no norte da Europa como Noruega, Suécia e Finlândia a floresta natural é um importante setor na economia nacional e ocupa uma larga extensão do território. Neste sentido, as políticas públicas nestes países estão voltadas, primeiramente, para conservação dos recursos naturais e, num processo mais lento, surgiram os programas para incorporar novas áreas verdes nas cidades. Os centros urbanos representam uma pequena parte na área total destes países, e sempre estiveram próximos das reservas florestais.

Em países no sul da Europa as áreas florestais são fragmentadas e faltam dados sobre as árvores existentes nas cidades, dificultando o planejamento das áreas verdes. Na Itália, o Plano Diretor dos Municípios define padrões para a quantidade de áreas verdes nas áreas privadas: nas unidades residenciais, $50 \%$ da área deve ser reservada para a vegetação e a recreação; e nas indústrias, $10 \%$ da área total deve ser destinada para espaços públicos com árvores (Meriggi, 2002). Porém, não existe ainda um planejamento urbano para interligar as florestas urbanas por meio de uma infra-estrutura verde, apenas leis nacionais para proteção dos parques (Martincigh, 2000). A Grécia definiu diretrizes para a porcentagem das áreas verdes em terrenos privados, mas não apresenta normas de plantio e manejo das árvores.

De forma geral, as pesquisas sobre florestas urbanas na Europa são limitadas. No intuito de juntar as informações já obtidas em diversos estudos foram criados projetos como o

\footnotetext{
${ }^{14}$ ReLeaf. Disponível em: < http://www.infoterra.co.uk/ureleaf/intro.html $>$. Acesso em março de 2008.

${ }^{15}$ CITYgreen. Disponível em: < http://www.americanforests.org/productsandpubs/citygreen// >. Acesso em março de 2008.
} 
Tree-ROUTE-Network ${ }^{16}$. Os objetivos principais são de organizar os dados necessários para o plantio e manejo das áreas verdes e determinar um conhecimento mais aprofundado sobre as árvores nas cidades européias (Nilsson e Radrup, 1997).

Em comparação com as cidades européias, as políticas públicas norte-americanas continuam mais avançadas pela estrutura de grupos e comitês específicos para cuidar das áreas verdes e pela interação com ONGs que realizam pesquisas paralelas e o mapeamento das árvores na cidade. Essa vantagem das políticas norte-americanas também é sentida em relação às cidades na Ásia, mas aos poucos este quadro está mudando.

As políticas públicas asiáticas voltadas para as áreas verdes foram intensificadas a partir da Segunda Guerra Mundial. Na década de 1960, com o avanço da urbanização, observou-se um movimento voltado para a conscientização do papel das áreas verdes nas cidades e sobre como integrar a vegetação com o crescimento vertical urbano. As Conferências sobre o Meio Ambiente, em 1972, em Estocolmo, e em 1992, no Rio de Janeiro, enfatizaram a necessidade do desenvolvimento sustentável para o planejamento das cidades por meio de regulamentos e incentivos do governo.

Cidades como Tóquio e Pequim vêm enfrentando o desafio de criar novas áreas verdes nos centros comerciais de alta densidade e com poucos espaços disponíveis. Um modelo que se destaca são os projetos urbanos na cidade de Cingapura com fachadas cobertas por vegetação, telhados verdes e pátios internos. A proposta é incorporar a vegetação nos edifícios de forma a criar novos espaços que já não existem nas vias públicas.

No Brasil, percebe-se que o inventário das árvores nas vias públicas é fundamental para a definição da estratégia de manutenção e criação de novas áreas verdes. Este processo de cadastramento já está em andamento nas cidades de Maringá, Curitiba e Porto Alegre. Porém, ainda falta uma metodologia mais ampla para facilitar a implantação de políticas públicas para arborização urbana em outras regiões do Brasil e de grupos de apoio ou ONGs que ajudem a levantar recursos para os programas de plantio de novas mudas, além de uma participação mais efetiva da sociedade.

\footnotetext{
${ }^{16}$ Tree-ROUTE-Network. Disponível em: < http://www.forestryguide.de/cgibin/ssgfi/anzeige.pl?db=forst\&nr=000445\&ew=SSGFI $>$. Acesso em março de 2008.
} 
Em seguida serão apresentadas as políticas públicas em destaque, voltadas para a implementação de novas áreas verdes nos Estados Unidos (Sacramento, Davis, São Francisco, Chicago, Los Angeles), na Europa (Munique, Londres, Malmö, Copenhagem), na Ásia (Tóquio, Pequim, Cingapura) e no Brasil (Curitiba, Porto Alegre, Maringá e São Paulo).

\subsubsection{ALGUMAS POLÍTICAS PÚBLICAS NOS ESTADOS UNIDOS}

Em 1999, a cidade de Sacramento iniciou uma pesquisa sobre as necessidades da arborização na cidade e definiu por meio da Organização Não-Governamental Sacramento Tree Foundation ${ }^{17}$ oito principais programas: Community Shade, Shade Tree Program, Mistletoe, Save de Elms Program (STEP), Nature, Seed to Seedling, Neighborwoods e Greenprint.

Os objetivos destes programas são: dobrar a quantidade de cobertura vegetal nos próximos quarenta anos, plantando mais de cinco milhões de novas árvores, quantificar o custo e benefício das árvores, definir políticas de manutenção das árvores e investir na educação e conscientização da população.

O Shade Tree Program (Sacramento Tree Foundation, 2000) quantificou os benefícios por meio de pesquisas realizadas pela USDA Forest Service (Mcpherson et al.,2004) em relação ao consumo de energia, qualidade do ar, redução de carbono, saúde da população, fauna e valor da propriedade.

O resultado do programa Shade Tree Program foi o plantio de 330.000 árvores em 130.000 propriedades, mais 10.000 árvores pelo Community Shade, representando $68 \%$ do objetivo final de 500.000 novas árvores na cidade.

Para um melhor aproveitamento do potencial de sombreamento dos edifícios, a prefeitura publicou o Tree Siting Guidelines ${ }^{18}$ com recomendações para o posicionamento das árvores nas calçadas e o Parking Lot Shading Design Guidelines ${ }^{19}$

\footnotetext{
17 Disponível no site: < http://www.sactree.com/aboutUs/aboutUsOverview.html > Acesso em outubro de 2007.

${ }^{18}$ Necessário pedido pelo correio.

${ }^{19}$ Disponível em:

$<<$ http://www.cityofsacramento.org/parksandrecreation/ppdd/pdf/SHADING_GUIDELINES_06-05-

03.pdf> Acesso em outubro de 2007.
} 
com uma lista de árvores que melhor se adaptam aos estacionamentos e à área de projeção das sombras pelas copas.

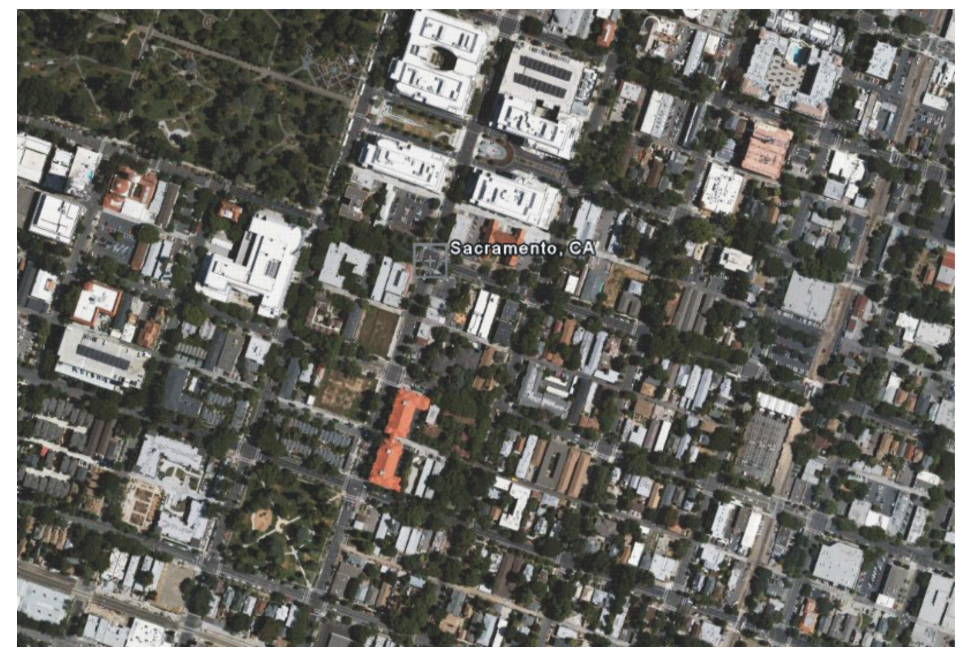

Figura 9: Foto aérea das ruas arborizadas da cidade de Sacramento, Califórnia.

Fonte: Google Earth. Disponível em: http://earth.google.com. Acesso em outubro de 2007.

Já as políticas públicas de Davis estão organizadas segundo uma hierarquia de planos, códigos e diretrizes mais específicas. Em 1963, iniciou-se o Programa de Floresta Urbana $^{20}$ na cidade organizado pelo comitê Street Tree mais tarde denominado Tree Commission. No começo, o principal objetivo do programa era o plantio de novas árvores, visando o sombreamento e a melhoria estética da comunidade.

Atualmente, existe o Community Forest Management Plan ${ }^{21}$ (City of Davis, 2002), a fim de manter as 30.000 árvores distribuídas em parques e ruas da cidade e tem como prioridades: remoção das árvores danificadas, cuidado com as espécies mais antigas, plantio de novas mudas e administração das atividades com o gerenciamento dos recursos.

O plantio acontece nos meses de janeiro e fevereiro. Nos outros meses são feitos levantamentos de novas áreas, onde poderiam ser plantadas árvores em ruas nas quais é preciso substituir as espécies existentes por novas.

\footnotetext{
${ }^{20}$ City of Davis Urban Forestry Program. Disponível em: $<\underline{\text { http://www.city.davis.ca.us/pcs/trees/ }>}$ Acesso em novembro de 2007

${ }^{21}$ Diponível em: < http://cityofdavis.org/pgs/trees/pdfs/CFMP-Final-Sept2002-ch1.pdf >. Acesso em março de 2008.
} 
Quando é feito o plantio, uma placa é colocada para informar sobre o programa e o tipo da espécie. Nas áreas de esquina, a vegetação a ser plantada deve ter altura menor que 1 metro para permitir a visão dos pedestres e ciclistas. Essa política de arborização urbana, desde 1992, já realizou o plantio de 7.000 novas árvores com 2.000 voluntários locais.

Em São Francisco, existem hoje mais de 100.000 árvores nas vias públicas, sendo a Prefeitura responsável por $1 / 3$ da floresta urbana existente (Prefeitura São Francisco, 2006) ${ }^{22}$, enquanto a manutenção e o cuidado da maioria das árvores nas calçadas (72.000) estão sob a responsabilidade do dono da propriedade. Somando-se o número de árvores existentes em praças, parques, vias e residências, tem-se um total de 668.000 unidades.

Em 1997 foi criado o Plano Sustentável, Sustainable Plan, voltado para a implantação de novas áreas públicas, parques e calçadas para pedestres. Estes lugares são parte do tecido urbano e elementos essenciais no desenvolvimento econômico da cidade (Urban Forestry Council, 2006). Este plano também previa formas de arrecadação de recursos para as obras e participação voluntária da comunidade local.

Em 2004, o Urban Forestry Council iniciou um projeto com pesquisadores do Departamento de Agricultura e Serviços Florestais (USDA) para realizar o levantamento da floresta urbana existente em São Francisco utilizando o modelo computacional UFORE - Urban Forest Effect Model $^{23}$. Este modelo foi criado no final da década de 1990 e, utilizando-se uma foto aérea da área, a análise é feita por meio da diferenciação de cores para definição de uso do solo e identificação de materiais e plantas (Nowak et.al., 2005).

Como resultado, estes estudos realizados pelo programa UFORE calcularam a cobertura vegetal na cidade (12\%) e a área ocupada por ruas, calçadas e outros pavimentos (43\%). Os edifícios representaram $26 \%$ da área total de São Francisco. Realizaram também um

\footnotetext{
${ }^{22}$ San Francisco Department of Public Works Community Newsletter, 2006. Disponível em: < http://www.sfgov.org/site/uploadedfiles/sfdpw/director/community newsletters/InTheWorksFall2006Eng lish.pdf $>$. Acesso em novembro de 2007.

${ }^{23}$ Urban Forest Effect Model. Disponível em: < http://www.ufore.org >. Acesso em dezembro de 2007.
} 
estudo detalhado de 106.789 árvores existentes apenas nas vias públicas, um valor que representa $16 \%$ do número total de árvores em São Francisco.

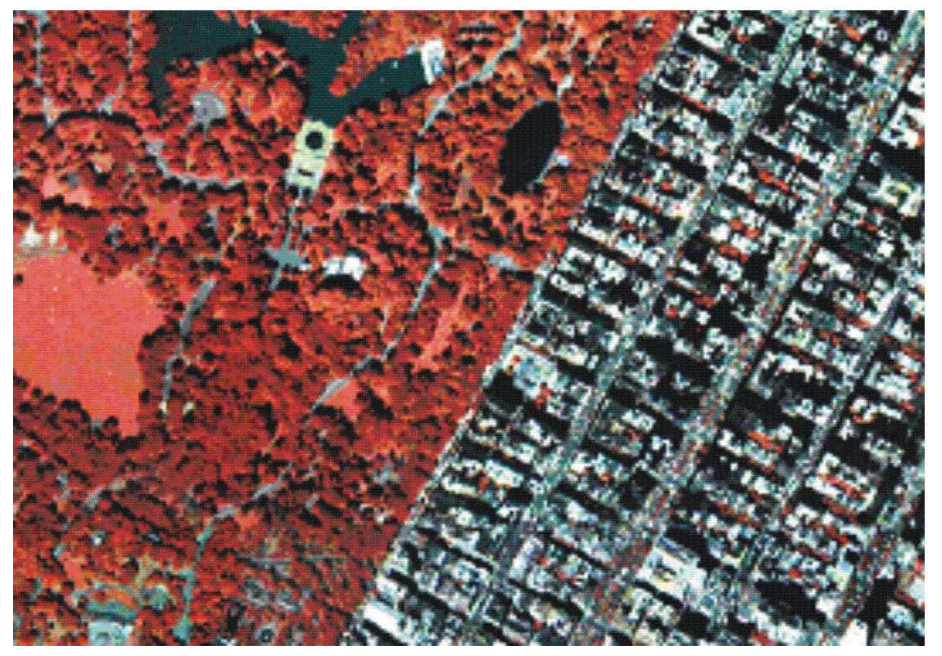

Figura 10: Análise da foto aérea pelo modelo UFORE.

Fonte: Manual UFORE Disponível em: 〈http://www.ufore.org/UFORE_manual.doc > Acesso em dezembro de 2007.

Além do UFORE, em 2007, São Francisco lançou o projeto Urban Tree Map ${ }^{24}$ a partir da parceria entre o Department of Public Works (DPW), Bureau of Urban Forestry (BUF), a ONG Friends of the Urban Forest (FUF) e a empresa Autodesk.

Este grupo de pesquisa teve como objetivo digitalizar a localização de todas as árvores existentes em São Francisco por meio de uma nova tecnologia, o Map Guide Open Source $^{25}$ (Figura 11).

Utilizando-se este programa é possível fazer uma busca por espécies, rua, bairro ou data de plantio da árvore. O programa é interativo, permitindo que o usuário adicione fotos, novas mudas já plantadas e até uma breve história da árvore. Facilita o acesso de informações como as projeções da cobertura vegetal, redução de $\mathrm{CO}_{2}$, fluxo das águas das chuvas, economia de energia e diminuição do efeito de ilha de calor.

\footnotetext{
${ }^{24}$ Urban Tree Map. Disponível em: < http://www.urbanforestmap.org/UrbanForest.pdf >. Acesso em dezembro de 2007.

${ }^{25}$ Mapguide Open Source. Disponível no site: < $\underline{w w w . a u t o d e s k . c o m / m a p g u i d e ~}>$. Acesso em dezembro de 2007.
} 


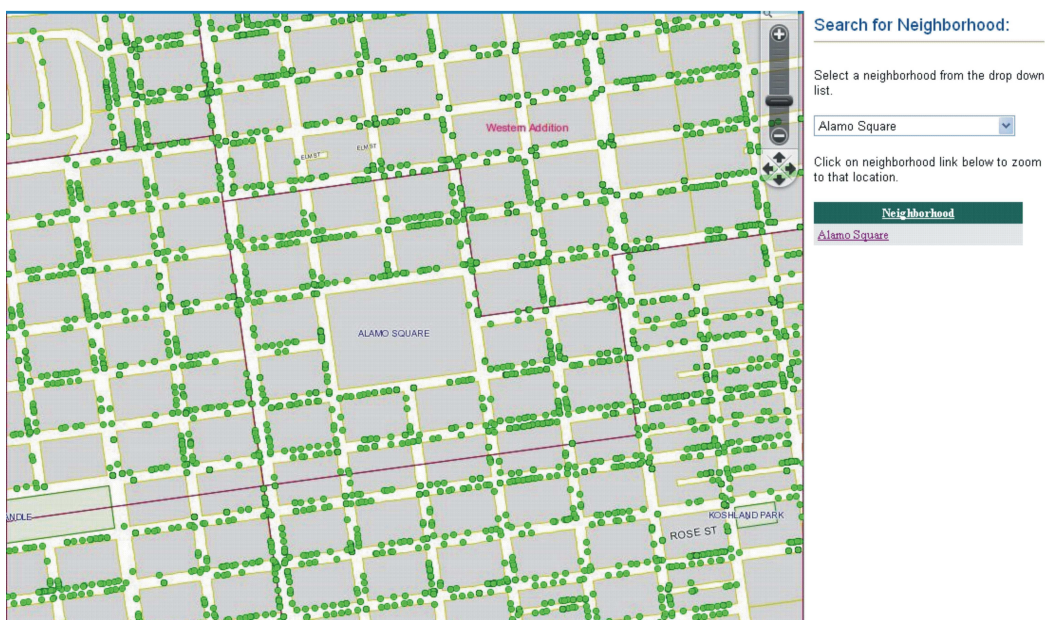

Figura 11: Árvores existentes no bairro Alamo Square por meio do Map Guide Open Source.

Fonte: Urban Tree Map. Disponível em: < http://www.sftreemap.org/>. Acesso em dezembro de 2007.

A Prefeitura de Chicago ${ }^{26}$ também se destaca por oferecer muitos incentivos para a implantação dos telhados verdes sendo que, nos últimos 10 anos, foram instalados aproximadamente 5 milhões de metros quadrados de tetos verdes na cidade. Um exemplo é a cobertura da Prefeitura que recebeu um jardim como forma de captação das águas da chuva (figura 12). Existe inclusive um guia ${ }^{27}$ específico para tratar dos programas de implantação de telhados verdes na cidade.

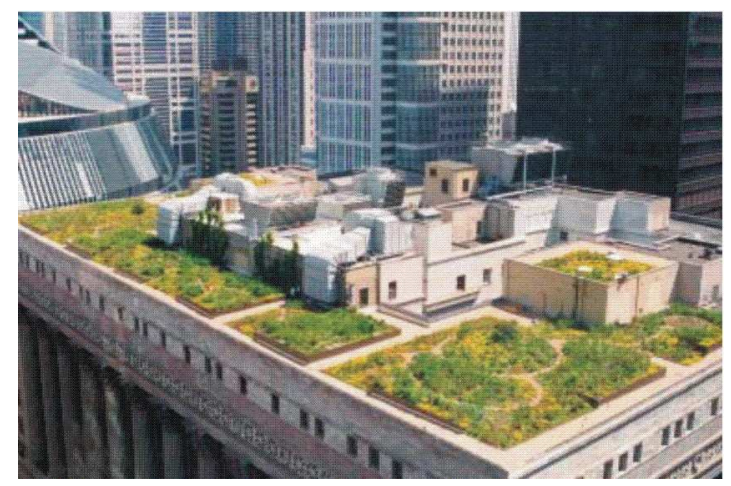

Figura 12: Telhado Verde na cobertura da Prefeitura de Chicago.

Fonte: Prefeitura de Chicago, 2003. Disponível em: <http://egov.cityofchicago.org >. Acesso em dezembro de 2007.

\footnotetext{
${ }^{26}$ Environmental Valuation \& Cost and Benefits News. Disponível em:

<http://envirovaluation.org/index.php?cat=17>. Acesso em dezembro de 2007.

${ }^{27}$ Chicago Green Roofs. Disponível em:




Em Los Angeles há o Million Trees Project. Criado em 2006, tinha com objetivo principal verificar a possibilidade de plantar um milhão de novas árvores na cidade. Dessa forma, foi realizado um estudo pelo USDA Forest Service para estimar a cobertura vegetal total, a quantidade de novas árvores que poderiam ser plantadas e o local (Figura 13).

Segundo a $U S D A^{28}$ (2006), a metodologia utiliza o Sistema de Informações Geográficas e fotos de satélite Quickbird para mapear as árvores existentes e quantificar a vegetação em 11 milhões de árvores. A cobertura vegetal representa 21\% da área de Los Angeles e existe um potencial para plantar mais 2.5 milhões de novas árvores.

De acordo com os resultados, observou-se que os locais com poucas árvores eram as áreas industriais e comerciais com $7 \%$ de cobertura vegetal, enquanto as áreas residenciais chegavam a 37\%. Os benefícios do plantio de um milhão de árvores foram calculados para um período de 35 anos e ficam entre US $\$ 1.3$ a US $\$ 2.0$ bilhões, sendo os benefícios anuais de US\$49 a US\$60 por árvore.

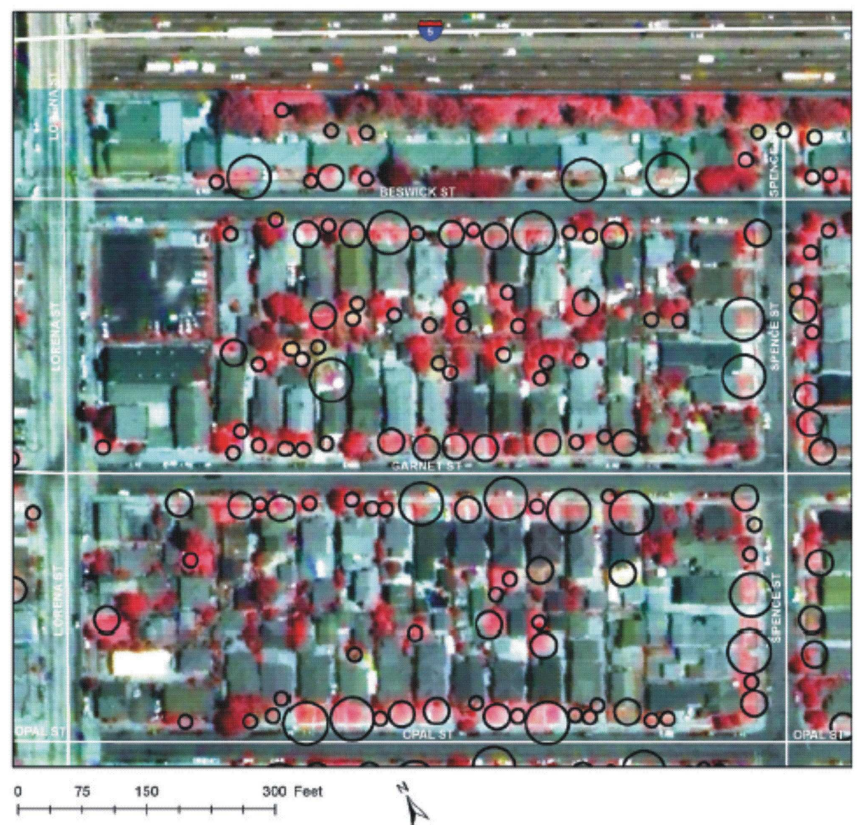

Figura 13: Proposta para Arborização urbana na cidade de Los Angeles, Califórnia. Fonte: USDA, 2003.

\footnotetext{
${ }^{28}$ USDA, 2003. Disponível em: < http://www.milliontreesla.org/mtabout5.htm $>$. Acesso em dezembro de 2007.
} 


\subsubsection{ALGUMAS POLÍTICAS PÚBLICAS NA EUROPA}

As pesquisas sobre a floresta urbana nas cidades européias foram incentivadas pela União Européia com a criação, em 1971, do órgão intergovernamental European cooperation in the field of Scientific and Technical Research - COST, responsável pela coordenação dos trabalhos científicos sobre arborização urbana e qualidade de vida. Atualmente, conta com um grupo de 30.000 pesquisadores de trinta e cinco países (Nielsen e Nilsson, 2007).

Considerando-se a falta de informações suficientes para analisar as ações de plantio e manutenção da vegetação urbana nas cidades européias, o projeto piloto COST Action E12 "Urban Forest and Trees" 29 foi o primeiro estudo que abrangem as principais cidades no continente europeu, possibilitando o levantamento de informações básicas sobre os cuidados com as árvores e diretrizes já estabelecias no período de 1999 a 2001.

Em Munique, a vegetação cobre uma extensão de 18.342 ha, 59\% da cidade, somandose as áreas rurais. Considerando o centro urbano, observa-se $16 \%$ de edifícios, $19 \%$ de superfícies impermeáveis e uma cobertura vegetal de $21 \%$.

Acredita-se que as áreas verdes contribuam com a absorção das águas entre 30\% e 38\%, e que as linhas de trem ajudam no balanço hídrico coletando $17 \%$ do total de chuvas em um ano. Por outro lado, o aumento de $10 \%$ nas superfícies pavimentadas corresponde à redução de 5\% na absorção das águas (Pauleit e Oppermann, 2002).

Em Munique o planejamento urbano das áreas verdes acontece em três etapas:

1. Instrumentos de Planejamento formal: tais como o Plano Diretor Regional e o Atlas Ambiental, publicado em 1990, apresentando os programas regionais de uso do solo, cobertura vegetal, qualidade do ar, energia, transporte e uso da água.

2. Estratégias informais: baseadas no Plano Diretor de Paisagens Ecológicas (Lehrstuhl für Landschaftsökologie - LÖK) e que seguem diretrizes denominadas de "Compacto, Urbano e Verde" (Compact, Urban, Green).

3. Projetos locais: como os projetos de requalificação das margens do rio Isar e o projeto de desenvolvimento sustentável de Messestadt Riem.

\footnotetext{
${ }^{29}$ Cost Action E12 - Disponível em: < http://www.cost.esf.org/ >. Acesso em fevereiro de 2008.
} 
Segundo o Department of Urban Planning and Building Regulation ${ }^{30}$ DUPBR (2005), a estratégia classificada como "Compacto, Urbano e Verde" mostra uma preocupação em se equilibrar o desenvolvimento da cidade com a preservação das florestas urbanas existentes.

$\mathrm{Na}$ escala regional, o objetivo de construção de 6.000 edifícios residenciais por ano, definido pelo conselho da cidade em 2001, segue a orientação de aumento da densidade, a fim de garantir uma meta de 1/3 da área total de Munique com vegetação e espaços públicos de lazer. A Figura 13 apresenta as duas diretrizes definidas para implantação de novas áreas com vegetação na cidade: o cinturão verde (Green Belt), formando um anel na periferia de Munique com atividade de permacultura, e dois corredores verdes que cortam a cidade em pontos estratégicos, sendo que um deles passa pelo centro da cidade e segue paralelo ao rio Isar (Figura 14).

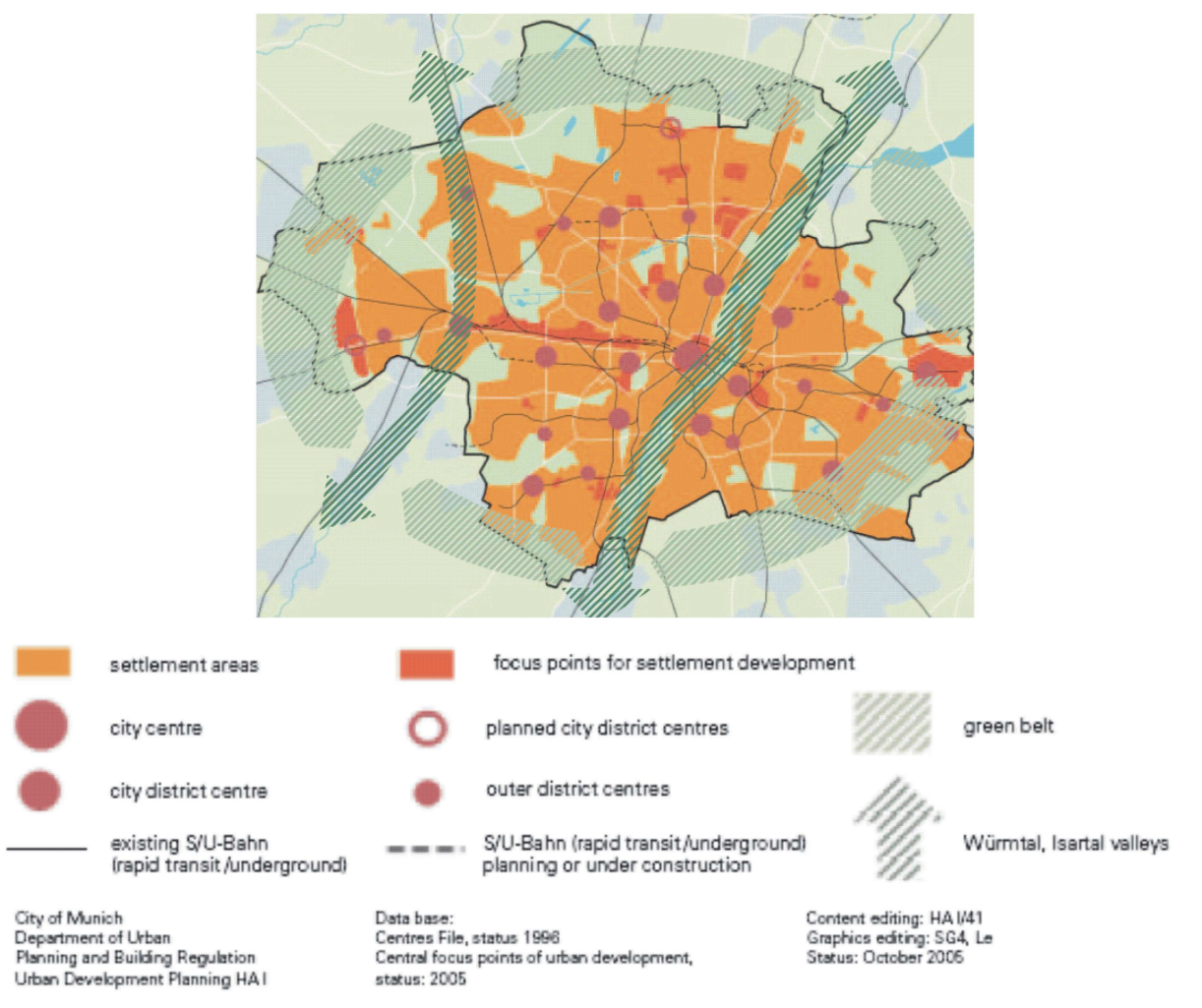

Figura 14: Plano Regional para implantação de novas áreas verdes na cidade de Munique, Alemanha.

Fonte: Development Report City of Munich, 2005.

\footnotetext{
30 Development Report: Shaping the future of Munich. Disponível em: < http://www.muenchen.de > Acesso em fevereiro de 2008.
} 
Em Londres, as reservas florestais ocupam o equivalente a $103.2 \mathrm{~km}^{2}$, correspondendo a $8 \%$ da área total. As principais espécies existentes nas reservas são nativas com folhas largas (80\%); as espécies exóticas representam $15 \%$ e praticamente não existem coníferas. Os plantios feitos em parques florestais são realizados no Thames Chase Community Forest, com objetivos de aumentar em $30 \%$ o número de árvores nos próximos 40 anos (Greater London Authority, 2007).

Em continuidade a este trabalho no Thames Chase, em 2002, o programa East London Green Grid propôs uma rede interligada de espaços públicos que pudessem conectar as diferentes áreas no Thames Gateway ${ }^{31}$ : residências, serviços, transporte, os cinturões verdes e o rio Tâmisa (Mayor of London, 2006).

Este programa está dividido em duas etapas, a primeira delas chamada prime, com um plano básico que aponta as deficiências e potencialidades da área e aplica os conceitos básicos do desenho da infra-estrutura verde. Em um segundo momento, a área é dividida em seis grupos de trabalho, nos quais serão propostas com mais detalhes as novas áreas verdes (Figuras 15 e 16).


Figura 15: Programa East London Green Grid.

Figura 16: Seis Grupos de Trabalho - Programa East London Green Grid.

Fonte: Greater London Authority, 2007.

\footnotetext{
${ }^{31}$ Thames Gateway é a extensão de $60 \mathrm{~km}$ dos dois lados do rio Tâmisa, na área leste da cidade. Formada por 7 sub-regiões de Londres, 3 áreas no lado leste e 2 no sudeste da Inglaterra.
} 
A cidade de Malmö, na Suécia, apresentou em 2001 propostas para manutenção e manejo das áreas verdes em conjuntos habitacionais, com o projeto $\mathrm{Bo} 01^{32}$ - City of Tomorrow, na European Housing Expo (Figuras 17 e 18).

A área de 25 ha localizada em uma região portuária Västra Hamnen foi transformada em um novo distrito com a construção de 559 unidades habitacionais.

Os objetivos principais eram de implantar um novo modelo de cidade com conceitos de sustentabilidade para revitalização desta antiga área industrial e explorar técnicas de construção, reuso das águas e geração de energia renovável. Uma das preocupações era criar um sistema de áreas verdes para captação das águas da chuva, por meio de pátios coletivos no interior das quadras, terraços com vegetação e telhados verdes.
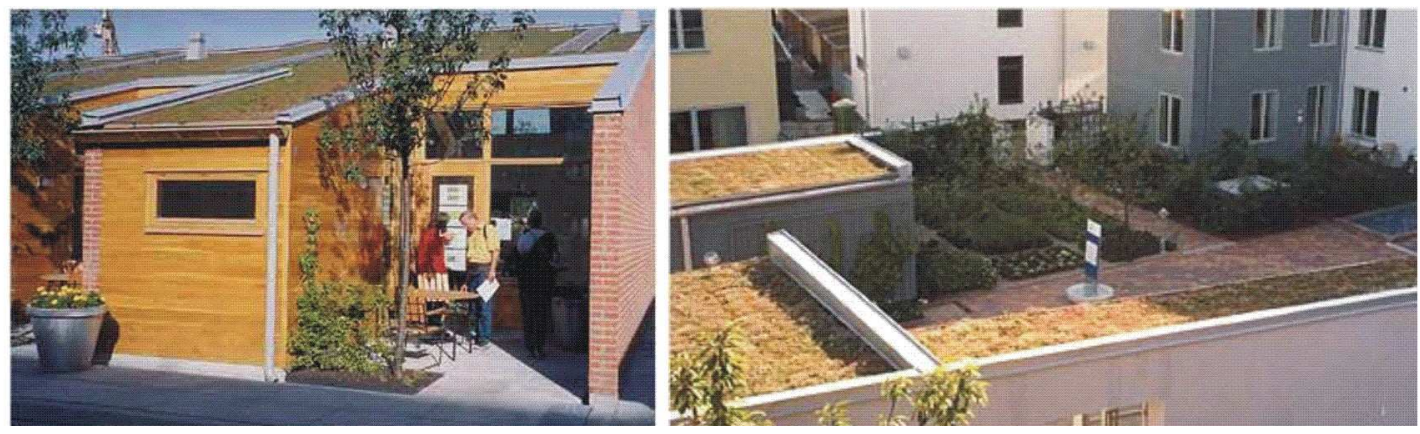

Figura 17: Modelo de residência com telhado verde em Malmö.

Figura 18: Implantação de terraços com vegetação nativa em Malmö.

\section{Fonte: Beer (2001).}

Em 2003, foi criado um Plano de Áreas Verdes (Gröplan for Malmö), pois em comparação com outras cidades suecas, Malmö tem áreas menores com vegetação e florestas naturais. O Plano foi divido em duas partes: a primeira levantou as principais características das áreas verdes como tamanho, localização e conexão com outras áreas (green network) e, a segunda propôs novas áreas, de acordo com a análise feita anteriormente, mas sem um detalhamento do desenho paisagístico. Os objetivos principais são de aumentar a quantidade total de áreas com vegetação e proteger as áreas naturais no desenvolvimento da cidade.

Uma das principais propostas do Plano é a criação de 16 corredores interligando as áreas verdes, sendo cinco corredores ligando o centro com as regiões periféricas (Figura

\footnotetext{
${ }^{32}$ Disponível em: < http://www.bo01.com/eng/start-eng/start-frame.html $>$. Acesso em fevereiro de 2008.
} 
20). Serão criadas mais 33 novas áreas verdes com projetos de recreação para a comunidade local. De acordo com o plano, a cidade terá um aumento de $19 \%$ na cobertura vegetal, a quantidade de áreas verdes por habitante cresce de $33 \mathrm{~m}^{2}$ para $48 \mathrm{~m}^{2}$ e o acesso à vegetação no interior aumenta de $2 \%$ a $33 \%$.
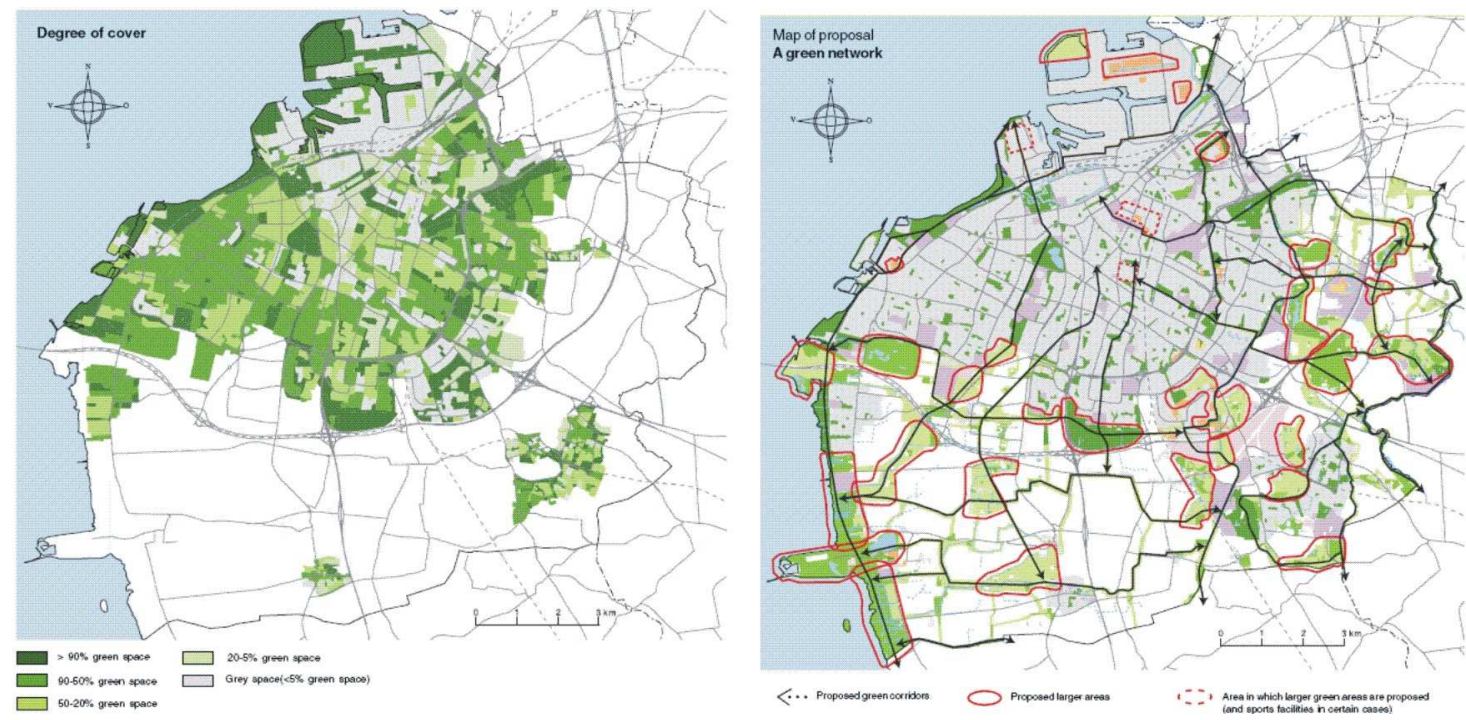

Figura 19: Cobertura vegetal na área mais urbanizada da cidade de Malmö, Suécia.

Figura 20: Proposta para interligação das Áreas Verdes - Green Network.

Fonte: Plano de Áreas Verdes de Malmö (City of Malmö, 2003).

\subsubsection{ALGUMAS POLÍTICAS PÚBLICAS NA ÁSIA}

Na cidade de Tóquio, os primeiros parques foram criados após a Reforma Meiji ${ }^{33}$ e o planejamento urbano em 1888 propôs o estabelecimento de 49 parques em uma área de 333 hectares, inspirados nos modelos europeus como o do Palácio de Buckingham em Londres e o Champs Elysee, em Paris. No entanto, uma revisão nas propostas reduziu o número de parques para 22, distribuídos em uma área de 221 hectares.

Aproximadamente $160 \mathrm{~km}^{2}$ de florestas urbanas da cidade de Tóquio, no Japão, foram destruídas nos ataques durante a Segunda Guerra Mundial. Após a guerra, a quantidade

\footnotetext{
${ }^{33}$ O Período Meiji se inicia em 8 de setembro de 1868, após a restituição do poder às mãos do Imperador Meiji Mutsuhito e termina com sua morte em 30 de julho de 1912. Seu início marca o fim da Era do Shogunato Tokugawa ( Período Edo), o fim do sistema feudal e a implantação das medidas modernizadoras no Japão. Seu processo de implantação é conhecido como Revolução Meiji. Disponível em: < http://www.klepsidra.net/klepsidra4/japao.html >. Acesso em fevereiro de 2009.
} 
de árvores nas vias ficou reduzida de 105.000 para 42.000 devido à falta de cuidados e os cortes ilegais pela população para usar a madeira no aquecimento das residências.

Do período de 1932 a 1939, o plano para as áreas verdes foi criado, segundo os modelos europeus da década de 1920. O plano de 1946 objetivava a criação de boulevards, faixas com árvores ao longo das vias e cinturões verdes nos subúrbios, reservando $10 \%$ da área total para vegetação urbana. No entanto, o novo plano para a cidade de Tóquio foi rejeitado pelas medidas econômicas propostas pelo americano Joseph M. Dogde que buscava reduzir a inflação e equilibrar os gastos do governo.

O crescimento da floresta urbana na cidade aconteceu a partir de 1959 com o evento das Olimpíadas no ano de 1964, propiciando o alargamento das vias e o plantio de novas mudas (Koshizawa, 1991).

Em 2006, preocupados em melhorar a qualidade das áreas verdes da cidade, o Governo Metropolitano de Tóquio (2007) reformulou o Plano Diretor das Áreas Verdes e criou um novo plano para os próximos 10 anos. Os principais objetivos são: formação de uma rede arbórea nas rodovias, conectando importantes áreas verdes; criação de uma ilha verde artificial; desenvolvimento de uma floresta urbana de 1000 hectares que corresponde a uma área de 1.500 campos de futebol; além disso, aumentar o número de árvores nas vias para 1 milhão de unidades.

Em 2005, a quantidade de árvores na vias públicas era de 480.000 e o plano municipal pretende aumentar para 700.000 no final de 2010 e chegar a 1 milhão no ano de 2015 . O processo de criação da rede verde está organizado em três etapas (Figura 21): primeiramente, as árvores serão plantas paralelas às vias, formando eixos verdes que cruzam a cidade. Em seguida, acontecerá a expansão da vegetação para dentro dos quarteirões e, por último, o crescimento e manutenção dessas áreas. Está prevista a retirada dos postes na área central e nos principais distritos comerciais para maior integração com os projetos urbanos de novos edifícios. 

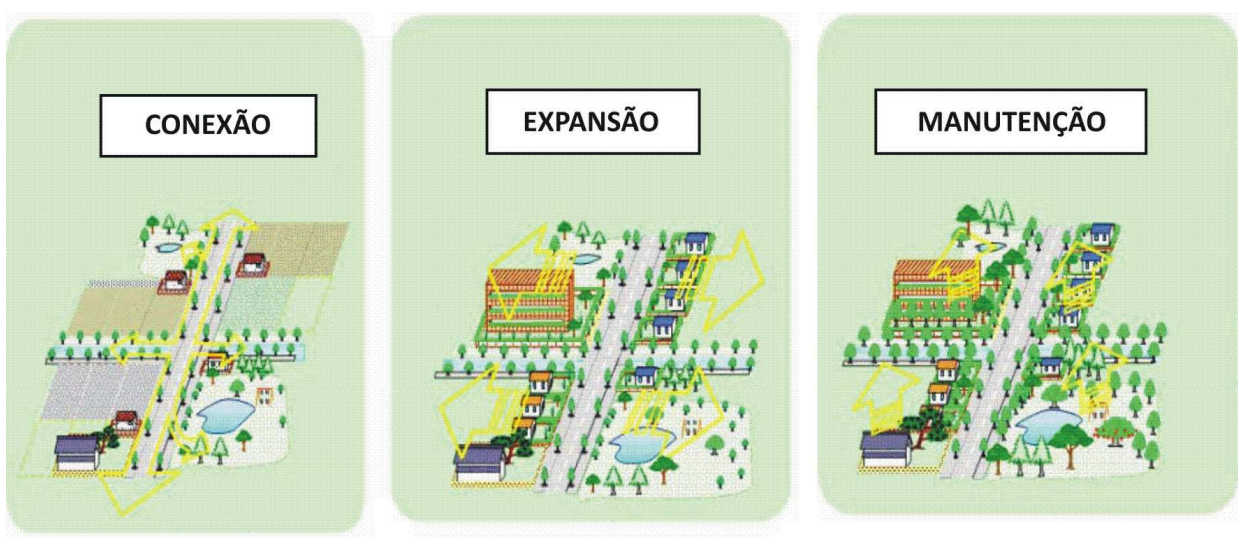

Figura 21: Processo de criação da rede verde na cidade de Tóquio.

Fonte: Governo Metropolitano de Tóquio (2007).

A Figura 22 mostra a forma de plantio na primeira etapa, as árvores e pequeno porte são inseridas entre as árvores de grande porte para obter um maior aproveitamento do espaço. A etapa de expansão está exemplificada na Figura 23, mostrando a integração das áreas verdes no interior da quadra.
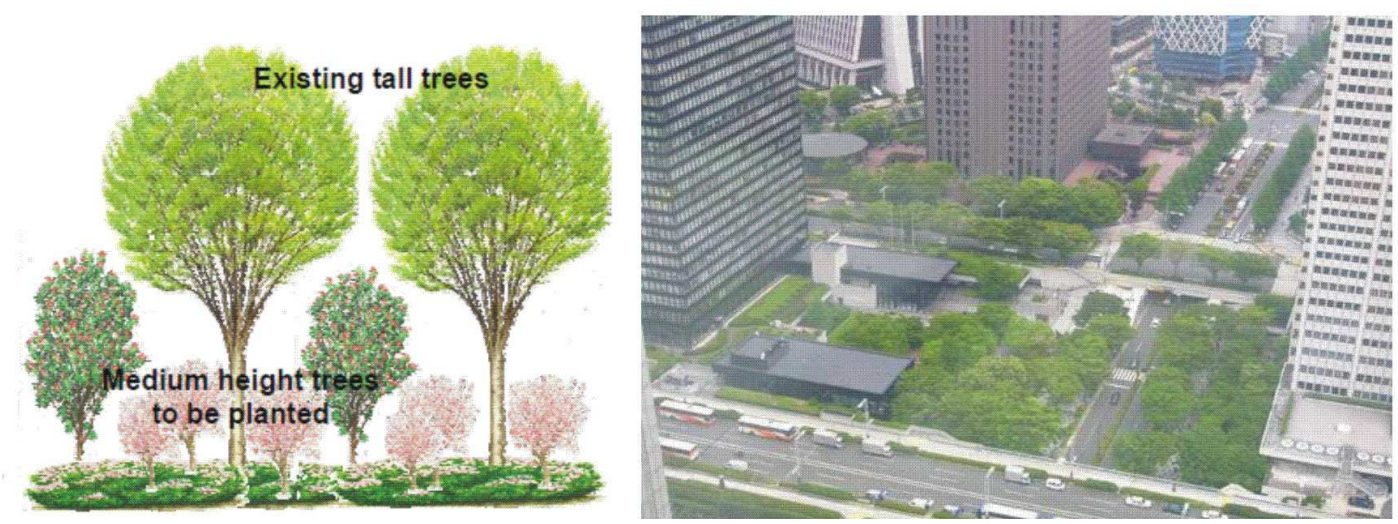

Figura 22: Integração das árvores existentes intercaladas por árvores de médio porte.

Figura 23: Integração das áreas verdes com projetos de edifícios comerciais. Nishi Shinjuku.

Fonte: Governo Metropolitano de Tóquio (2007).

A ilha artificial Umi-no-Mori ${ }^{34}$ (Figura 24) será um grande parque formado por 480.000 árvores distribuídas em uma área cinco vezes e meia o parque Hibiya, com 88 ha e o governo prevê a sua conclusão em 30 anos.

\footnotetext{
${ }^{34}$ Disponível em: < http://www.uminomori.metro.tokyo.jp/index_e.html $>$. Acesso em janeiro de 2009.
} 


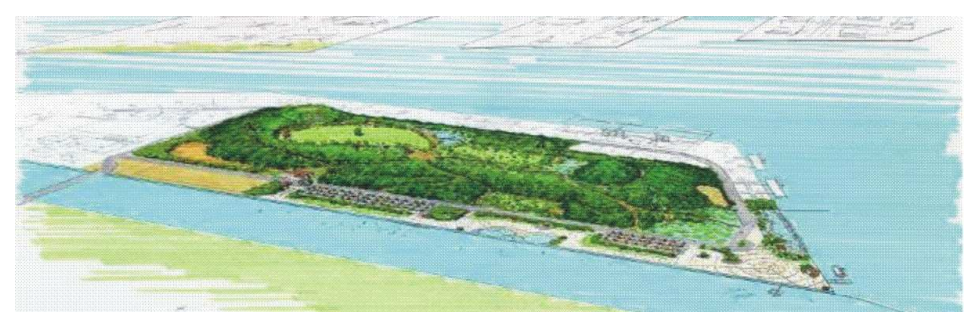

Figura 24: Projeto para a ilha Umi-no-Mori.

Fonte: Governo Metropolitano de Tóquio (2007).

Nos últimos dez anos a cidade de Pequim, na China, tem crescido continuamente, segundo o Plano Diretor de 1992 que determina o sistema rodoviário de seis anéis que começam na cidade proibida, intercalado por cinturões verdes e cidades satélites (Figura 25). Existem dois principais cinturões verdes: o interno, localizado no limite da cidade central e as cidades satélites; e o cinturão mais externo, localizado entre os limites do subúrbio e a área rural.

Até 2000, um terço da área do cinturão foi transformado em unidades residenciais para fazendeiros e existem dificuldades para se manter o restante das áreas como floresta urbana.

Em 2001, quando foi oficialmente anunciado como a sede dos jogos olímpicos de 2008, o governo criou um conjunto de planos a ser realizado em três etapas (Wang et $a$, 2005):

- Até 2008: criar a "Cidade Olímpica Verde", seguindo as diretrizes do Plano Diretor do Meio Ambiente que incluem aspectos sobre energia, transporte, qualidade do ar, água e floresta urbana. Sobre a vegetação, buscava-se atingir uma cobertura vegetal de $40 \%$ na cidade e a criação um cinturão verde de $100 \mathrm{~m}$ em cada lado do $4^{\circ}$ anel rodoviário.

- Até 2020: criar uma "Moderna Cidade Internacional" destacando as características de cada distrito.

- No longo prazo: criação da "Eco Cidade" com um sistema ecológico formado por áreas verdes no formato de cunhas (green wedges), parques e corredores verdes. 


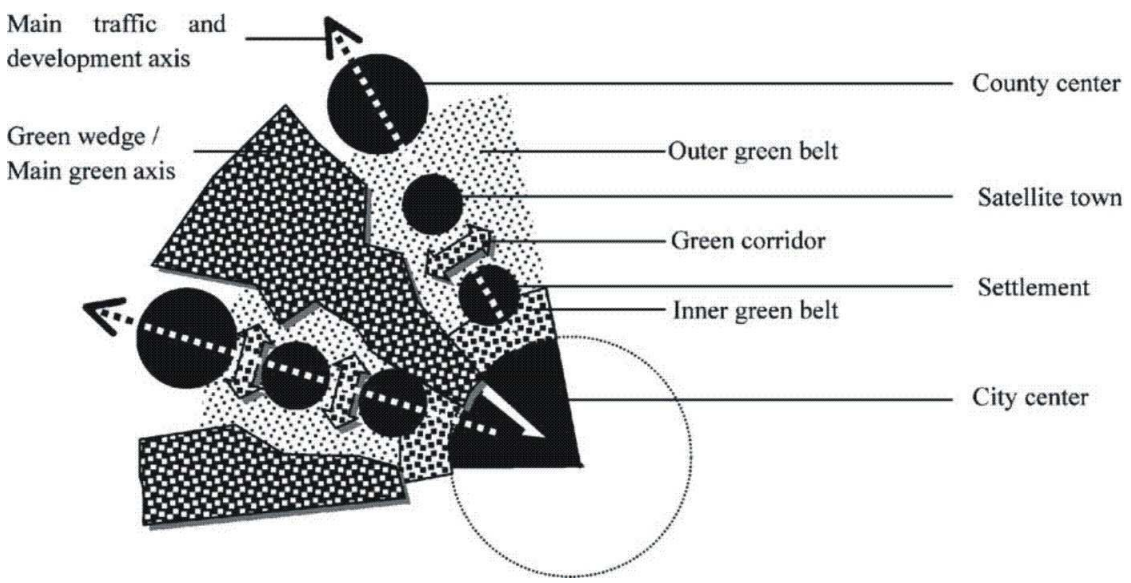

Figura 25: Proposta para construção de novas unidades residenciais e a infraestrutura verde necessária para o desenvolvimento da cidade de Pequim.

Fonte: Wang et al (2004).

As políticas públicas para as áreas verdes em Cingapura iniciaram-se na década de 1960 quando o país crescia com uma rápida urbanização e industrialização. A partir de 1968 o governo definiu algumas propostas de uso de solo e controle da poluição visando tornar Cingapura uma grande “cidade jardim”. Na década de 1980, as preocupações com o aquecimento global e o efeito de ilha de calor na cidade resultaram na criação do Plano Verde que descreveu diretrizes para transformar a cidade em um modelo de cidade sustentável até o ano 2000.

Em 2002, foram lançadas novas diretrizes para os próximos 10 anos no Plano Verde ${ }^{35}$ da cidade, com os seguintes objetivos:

- Mudanças Climáticas e qualidade do ar: manter o índice bom no padrão de poluição em $85 \%$ do ano e médio nos $15 \%$ restantes. Reduzir as partículas poluentes (PM $2,5)^{36}$ para uma média anual de $15 \mathrm{mg} / \mathrm{Nm}^{3}$ até 2014 .

- Água: aumentar a permeabilidade da superfície do solo em $67 \%$ da área total da cidade. Diminuir o consumo per capita para 155 litros por dia.

- Manejo do lixo: aumentar a reciclagem em 60\% até 2012.

\footnotetext{
${ }^{35}$ Singapure Green Plan 2012. Disponível em: < http://www.mewr.gov.sg/sgp2012/ >. Acesso em janeiro de 2009 .

${ }^{36}$ PM 2, 5 - São micro partículas (Particulate Matter) suspensas no ar com um diâmetro de 2,5 $\mu$. Disponível em: < http://www.greenfacts.org/glossary/pqrs/PM10-PM2.5-PM0.1.htm >. Acesso em janeiro de 2009.
} 
- Conservação da floresta urbana: criar novos parques e corredores verdes.

As propostas possibilitaram um crescimento da cobertura vegetal de 36\% em 1986 para 47\% em 2007. Esse resultado foi alcançado por meio de estratégias específicas como, por exemplo, o plantio de espécies de rápido crescimento nas vias, substituição do concreto nos estacionamentos e criação de $360 \mathrm{~km}$ de corredores verdes fazendo a ligação entre os parques existentes na cidade.

No entanto, a grande contribuição das políticas públicas na cidade é o incentivo na implantação de telhados verdes, fachadas com vegetação e incorporação de pátios vegetados (sky garden) no interior dos edifícios. Podem-se citar a o telhado verde da Faculdade Artes e Design da Universidade Tecnológica Nanyang (Figura 26), o projeto Fusionopolis do arquiteto Ken Yeang (Figura 27) com edifícios residências de 1,4km de altura e jardins internos interligando as áreas públicas que será concluído até 2010 (Figuras 28 e 29) e o projeto South Beach, por Norman Foster (Figuras 30 e 31), com edifícios comercias e residenciais no centro da cidade que incorporam aspectos da arquitetura bioclimática e utilizam átrios internos com vegetação.

As Figuras 32 e 33 mostram outros exemplos de integração das áreas verdes na cidade de Cingapura.

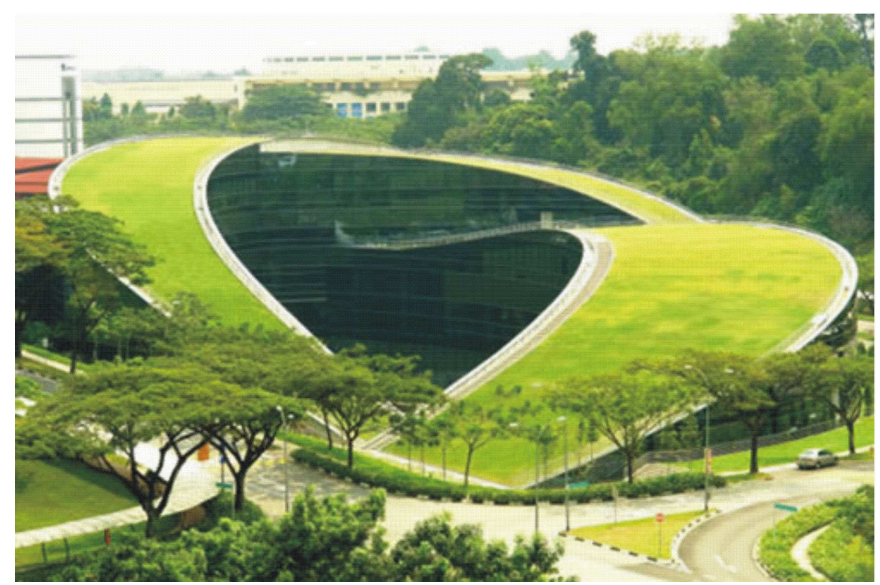

Figura 26: Telhado verde na Universidade Tecnológica Nanyang em Cingapura

Fonte: Disponível em: < http://www.neatorama.com/2008/01/23/green-roof-of-nanyangtechnological-university-in-singapore/ >. Acesso em janeiro de 2009. 

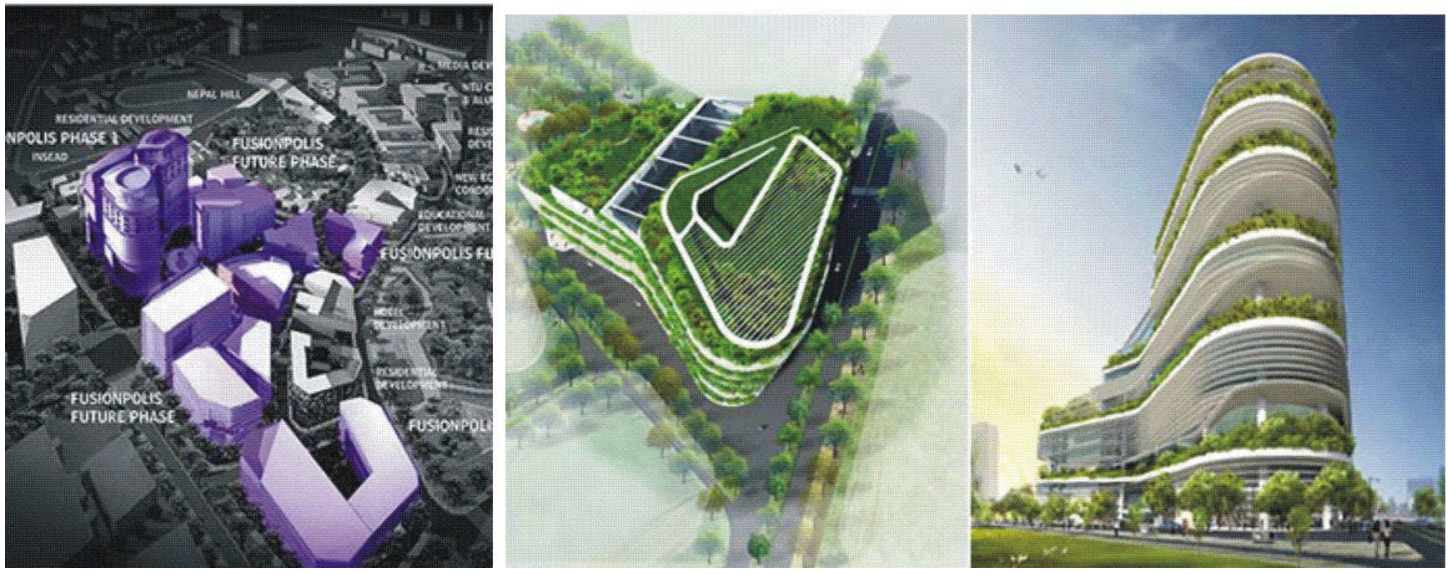

Figura 27: Proposta urbana do Fusionolopis

Figura 28: Construção de telhados verdes na cobertura dos esdifícios. Projeto Fusinopolis.

Figura 29: Lateral de um dos edifícios com vegetação na fachada. Projeto Fusionopolis.

Fonte: Disponível em: < http://landscapeandurbanism.blogspot.com/2008/07/fusionopolisby-ken-yeang.html >. Acesso em janeiro de 2009.
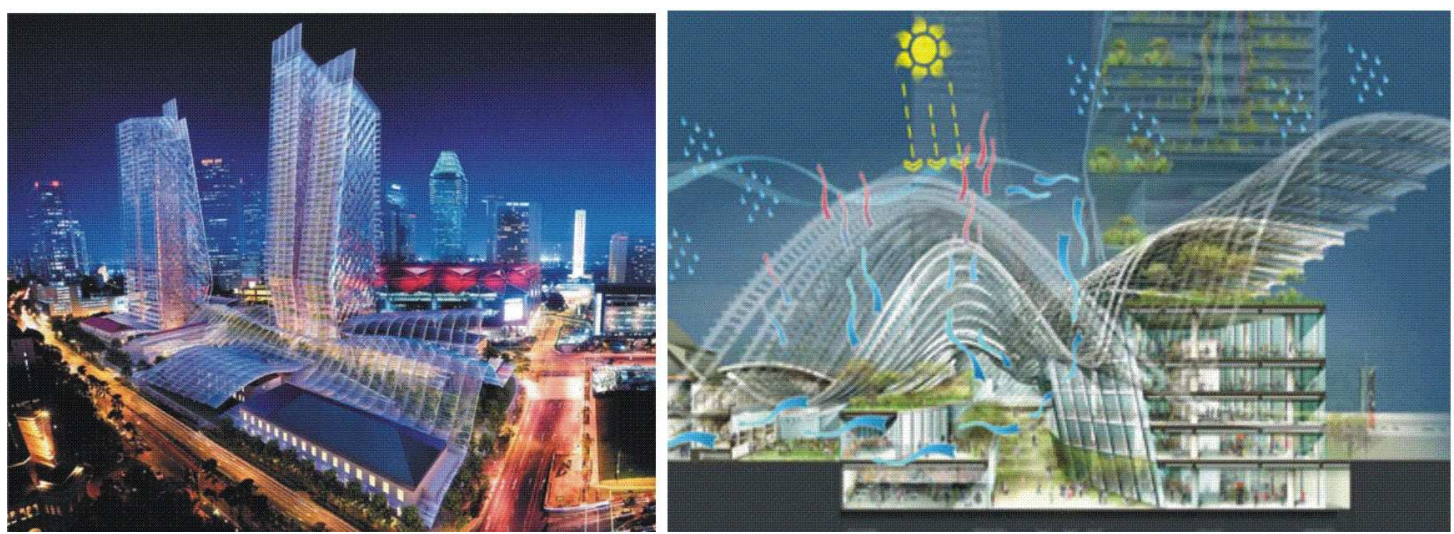

Figura 30: O Projeto South Beach no centro de Cingapura.

Figura 31: Estratégias bioclimáticas no projeto South Beach.

Fonte: Disponível em: 〈http://www.ura.gov.sg/skyline/skyline07/skyline0705/text/02.htm>. Acesso em janeiro de 2009. 

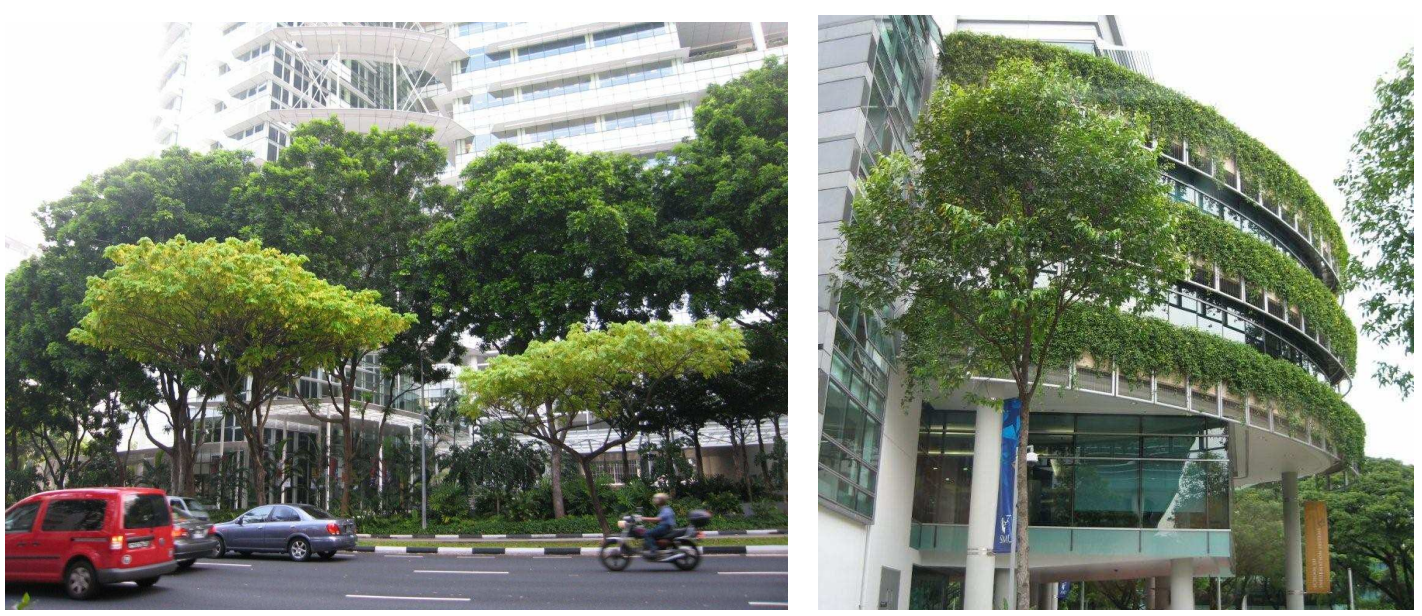

Figura 32: Arborização urbana na cidade de Cingapura (Foto: D. Duarte).

Figura 33: Fachada com vegetação. Cidade de Cingapura (Foto: D. Duarte).

\subsubsection{ALGUMAS POLÍTICAS PÚBLICAS NO BRASIL}

Segundo a Prefeitura de Curitiba (2007), a cobertura florestal, em 2005, era de 49.02 $\mathrm{m}^{2}$ por habitante, mantendo-se estável nos últimos 18 anos. Somando-se com a vegetação nas vias públicas, a cidade chega a $51.5 \mathrm{~m}^{2}$ de área verde por habitante. Assim, observa-se que $17.97 \%$ da superfície do município são ocupados por vegetação arbórea.

Estima-se hoje um total de 300.000 árvores plantadas nas vias públicas, sendo a maior parte realizada pela Administração Municipal. Estas ações foram incentivadas, primeiramente, com a criação do Plano Diretor de Arborização, em 1974. Em 1996, a Secretaria Municipal do Meio Ambiente - SMMA iniciou o processo para recensear a arborização viária através de um financiamento do Fundo Municipal de Meio Ambiente - FMMA, levantando um terço das árvores existentes na cidade.

Em 2005, a Fundação Ministério do Meio Ambiente- FMMA investiu no Censo Arbóreo das ruas, no qual a primeira etapa foi concluída com o cadastro de 75.000 árvores em 17 bairros. Espera-se completar os 75 bairros nos próximos anos, realizando em cada área o Plano de Ação que inclui plantios, remoções, podas e substituições.

Nas ruas de Porto Alegre foram encontradas 173 espécies arbóreas, dentre as quais 18 são predominantes, totalizando $83,53 \%$ da população arbórea viária. O manejo e preservação da arborização viária não constituem uma atividade simples. Para promover um correto manejo das áreas verdes foi elaborado o Plano Diretor de Arborização 
Urbana, em 2000, com a função de estruturar métodos e medidas adotadas para preservação, manejo e expansão das árvores nas cidades, de acordo com as demandas técnicas e as manifestações de interesse das comunidades locais (SMAM, 2008).

Assim, foi levantado um inventário das árvores da cidade para facilitar a definição das diretrizes de planejamento, produção, implantação, conservação e administração das árvores públicas, incluídas no Plano Diretor de Arborização Urbana.

Pensando na conscientização das pessoas para a importância da vegetação nas cidades, criou-se a campanha Porto Alegre, Cidade da Educação Ambiental, em 2005, no intuito de promover a participação efetiva das crianças e jovens de diferentes comunidades, incentivando a conservação do meio ambiente, através de um processo educativo efetivo e comprometido com a adoção dos princípios e práticas da educação ambiental.

Segundo a Secretaria de Serviços Públicos e Meio Ambiente (2003), o progresso da cidade de Maringá aconteceu harmoniosamente sem perder as características de cidade planejada. São $40 \mathrm{~m}^{2}$ de área verde por habitante, sendo $27 \mathrm{~m}^{2}$ correspondentes à arborização de ruas e praças e $13 \mathrm{~m}^{2}$ reservas e parques, no perímetro urbano.

Em 1999, a Secretaria Municipal do Meio Ambiente - SEMA contabilizava 77.273 árvores de 80 espécies diferentes. Assim, por possuir uma das mais altas taxas de concentração de área verde com $27 \mathrm{~m}^{2} /$ hab, passou a ser considerada a "cidade verde" ou "cidade ecológica" no Brasil. A Figura 34 mostra a vista aérea de Maringá e o desenvolvimento da arborização na cidade.

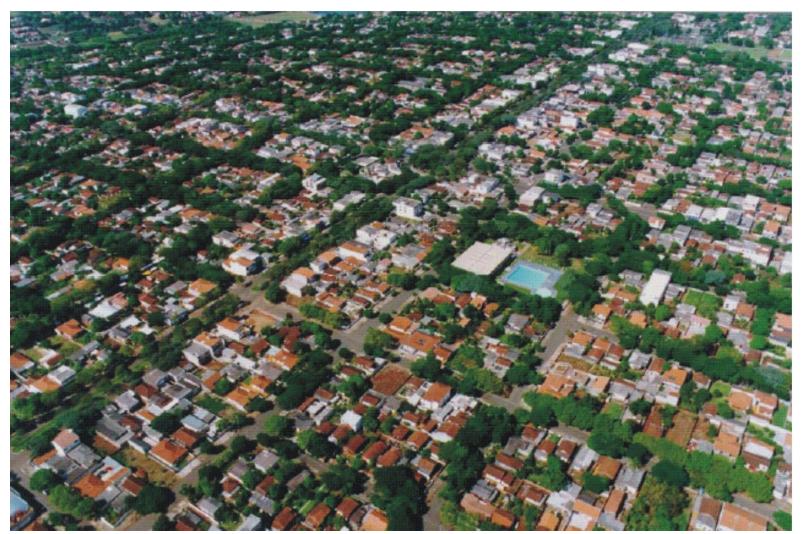

Figura 34: Arborização nas vias de Maringá.

Fonte: Silva (2006). 
Em relação aos projetos destinados à manutenção e criação novas áreas verdes, a Universidade Estadual de Maringá (UEM) criou o Censo da Árvore, em parceria com a Centro Universitário de Maringá - Censumar e com as empresas Gelita do Brasil e Copel, para estudar as árvores e verificar as condições de plantio. A maior contribuição do Censo da Árvore foi a criação do Instituto da Árvore. Este órgão conta com mais de 100 associados, sendo responsável pela elaboração do Plano Diretor da Árvore que define os trabalhos de manejo, forma de substituição e onde serão plantadas as novas mudas. Um primeiro resultado do desenvolvimento do Plano Diretor da Árvore é o plantio de 208 mudas no centro da cidade, o que foi viabilizado através de uma parceria com a Associação Comercial e Empresarial de Maringá -ACIM (Gatti, 2007).

O projeto RG da Árvore ${ }^{37}$ é um programa de pesquisa, patrocinado pela ONG Tudo Verde $^{38}$ em que cada árvore terá um número de cadastro com as principais informações e foto, podendo ser acessado pela Internet. Em 139 dias mais de oito mil árvores foram cadastradas e pretende-se realizar a atualização dos dados a cada 12 meses (O Diário do Norte do Paraná, 2007).

A partir da Legislação Municipal, a Prefeitura da cidade de São Paulo vem desenvolvendo programas de arborização para incentivar o aumento da cobertura vegetal na cidade. As iniciativas acontecem em dois níveis: a arborização das vias públicas e criação de novos parques.

Em relação à cidade de São Paulo, a SVMA, em parcerias com as subprefeituras, visa ampliar a arborização e a permeabilidade do solo por meio do Projeto Calçadas Verdes e Permeáveis $^{39}$, em vigor desde janeiro de 2007. As Subprefeituras deverão apresentar projetos à SVMA, atendendo aos itens de libertação da base das árvores com espaços adequados ao seu crescimento nos canteiros, abertura de faixa permeável nas calçadas e colocação de grama ou forração na faixa permeável.

\footnotetext{
${ }^{37}$ Programa RG da Árvore. Disponível em: < http://www.rgdaarvore.com/>. Acesso em maio de 2008.

${ }^{38}$ ONG Tudo Verde. Disponível em: < http://www.tudoverde.org.br/>. Acesso em maio de 2008.

${ }^{39}$ Disponível em: < http://portal.prefeitura.sp.gov.br/noticias/sec/meio_ambiente/2007/01/0006> Acesso em outubro de 2007.
} 
Esta iniciativa dá continuidade ao Projeto Passeios Livres ${ }^{40}$, de novembro de 1995 , definindo novos padrões para as calçadas. Em situações com calçadas maiores que 2,0m houve a divisão em três faixas: acesso do pedestre, passeio livre e uma última faixa para colocação de equipamentos e plantio de árvores. Já foram implantados $144 \mathrm{~km}$ do novo calçamento, e estavam previstos mais de $100 \mathrm{~km}$ até o final de 2007.

Em paralelo aos programas de arborização urbana foi criado o Projeto dos Parques Lineares $^{41}$ pela Lei $n^{\circ} 13.430 / 2002$, como sugestão do Plano Estratégico da Cidade (Figuras 35 e 36 ).

O principal objetivo é de recuperar fundos de vale e cursos d'água, resgatando o papel dos fundos de vale como parte do sistema de drenagem natural, e acrescentando-lhes função social. A meta era implantar 22 parques lineares até 2008, sendo os cinco primeiros financiados pelo Fundo de Desenvolvimento Urbano (Fundurb), dois parques com recursos da própria SVMA e os demais por meio do Termo de Compensação Ambiental.
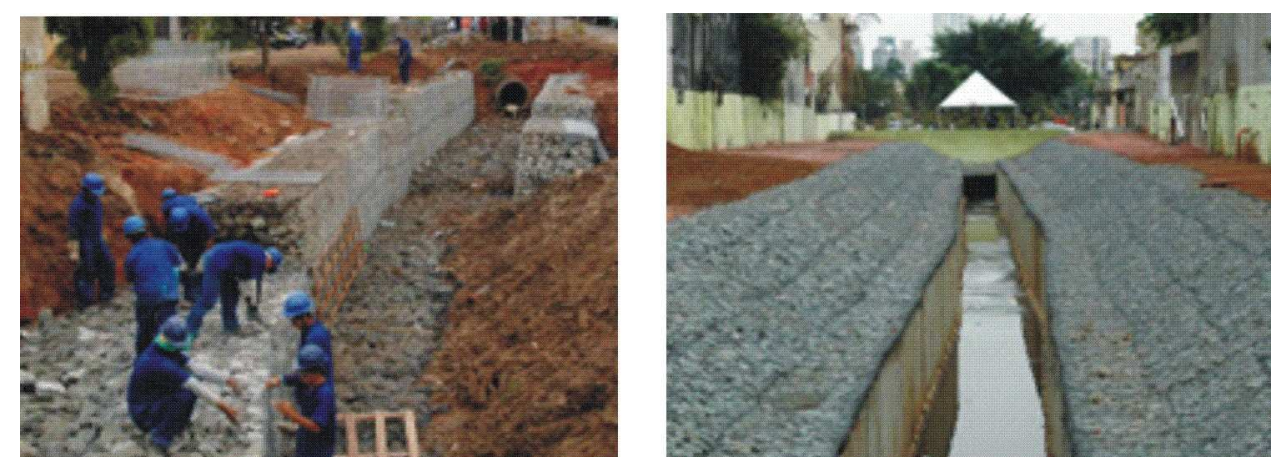

Figura 35: Andamento das obras do Parque Linear do Sapé, no Butantã.

Figura 36: Andamento das obras do Parque Linear da Invernada, em Santo Amaro.

Fonte: Prefeitura de São Paulo. Disponível em:

<www.prefeitura.sp.gov.br/portal/a_cidade/noticias $>$ Acesso em outubro de 2007.

Em janeiro de 2008, a Prefeitura lançou o Projeto 100 Parques para São Paulo ${ }^{42}$, planejando criar mais 25 novos parques até o final de 2008 e, somando-se os 41 parques

\footnotetext{
${ }^{40}$ Disponível em: < http://ww2.prefeitura.sp.gov.br/passeiolivre/conheca.asp $>$ Acesso em outubro de 2007.

${ }^{41}$ Disponível no site: < http://www.prefeitura.sp.gov.br/portal/a_cidade/noticias/index.php?p=15453> Acesso em outubro de 2007.
} 
municipais existentes, a cidade terá um total de 66 parques. Isto corresponde a uma área total aproximada de 18.6 milhões de $\mathrm{m}^{2}$ e não inclui os parques estaduais e nem as Áreas de Proteção Ambiental. Nos próximos anos a SVMA espera construir outros 34 parques para completar o projeto.

${ }^{42}$ Prefeitura de São Paulo. Disponível em: $<$ http://www.prefeitura.sp.gov.br/portal/a cidade/noticias/index.php?p=21205 > Acesso em fevereiro de 2008. 


\section{O EFEITO DA VEGETAÇÃO NO MICROCLIMA URBANO E ALGUNS MODELOS DE CÁLCULO MAIS REPRESENTATIVOS}

Inserir a vegetação em áreas urbanas é uma das principais estratégias para reduzir o efeito de Ilha de Calor, uma vez que as plantas representam um importante papel de regular o clima urbano (Yu, 2006). Para ser mais preciso, a vegetação reduz o efeito de Ilha de Calor, não por meio da redução das temperaturas, mas pelo fato de aquecer menos o ar (Dimoundi e Nikolopoulou, 2000).

Os estudos de Sailor (1995) mostram que o albedo dos materiais e o uso da vegetação influenciam diretamente o microclima urbano, chegando a reduzir as temperaturas do ar em $1.3^{\circ} \mathrm{C}$ ao aumentar em $14 \%$ as áreas verdes na cidade de Los Angeles, Estados Unidos.

Os efeitos das árvores afetam o microclima urbano em dois níveis: no conforto humano e na energia consumida pelos edifícios (Miller, 1988 apud Carter, 1995). Segundo Oke (1989), o efeito mais importante é a prevenção do aquecimento dos canyons urbanos, promovendo um alívio nos ganhos de calor pela radiação solar por meio da combinação de absorção e evaporação (Emmanuel, 2005).

Segundo Wilmers (1988), esta interação em diferentes áreas urbanas depende da rugosidade do material, das estruturas urbanas e da porcentagem de vegetação existente. Em seus estudos comparou arranjos urbanos com e sem vegetação e diferentes níveis de saturação de água. Em condições ideais de água a evapotranspiração pode atingir $80 \%$ em áreas verdes, enquanto que em áreas com pouca vegetação a influência do fluxo de calor sensível e do solo é mais significativa que o fluxo de calor latente. Segundo Santamouris (2001), a relação entre o fluxo de calor sensível e o fluxo de calor latente é representada pela razão de Bowen $^{43}$ sendo o valor 5 típico para áreas urbanas, 110 para áreas de deserto e 0.1 sobre os oceanos tropicais (Taha, 1997 apud Santamouris, 2001).

As condições climáticas de temperatura e umidade são influenciadas pela troca de energia entre os elementos na superfície do solo e do ar. O processo de troca de energia

\footnotetext{
${ }^{43}$ A razão de Bowen é a proporção do calor sensível H em relação ao calor latente E: $\mathrm{Fl}=\mathrm{H} / \mathrm{E}$, sendo $<0.1$ para superfícies úmidas e $>10$ para superfícies secas.
} 
é complexo em ambientes homogêneos e muito mais complicado nos ambientes urbanos com estruturas de características heterogêneas. Porém, a energia disponível na superfície do solo, em termos de radiação e outras fontes de energia, são equilibradas com o fluxo de calor e vapor de água no ar, sendo propagada na atmosfera por meio da dispersão da ventilação (Jansson, 2006).

A relação entre o fluxo de energia e o clima pode ser ilustrada segundo a primeira lei da termodinâmica (conservação de energia), em que a energia não é criada ou destruída, apenas convertida a partir de uma forma para a outra. Isso significa que esse sistema tem duas possibilidades (Oke, 1987):

1. Energia de entrada = Energia de Saída

2. Energia de entrada $=$ Energia de Saída + Energia Armazenada

Assim, para um único elemento na superfície, o balanço de energia é dado por:

$\mathbf{Q}=\mathbf{Q}_{\mathbf{H}}+\mathbf{Q}_{\mathbf{E}}+\mathbf{Q}_{\mathbf{G}}$

Onde:

$\mathbf{Q}=$ radiação total

$\mathbf{Q}_{\mathbf{H}}=$ fluxo de calor sensível

$\mathbf{Q}_{\mathbf{E}}=$ fluxo de calor latente

$\mathbf{Q}_{\mathbf{G}}=$ calor transportado do solo ou para o solo

A vegetação tem um importante papel devido às suas propriedades especiais no balanço de energia, dependendo do processo de evapotranspiração, a cobertura vegetal e a superfície com água diminuem os picos de temperatura durante o dia.

Segundo Wilmers (1991), o microclima existente dentro das áreas verdes foi relatado por diversas pesquisas que mediram os valores de temperatura e umidade. Porém, poucos são os estudos que comprovam o efeito da vegetação no microclima, pois cada cobertura vegetal tem diferentes valores para a razão de Bowen. De acordo como o balanço hídrico, a radiação é convertida em energia para transpiração e o fluxo de calor sensível é menor. O efeito das áreas verdes pode ser percebido em pequenas distâncias entre 50m e 
$100 \mathrm{~m}$, com diferenças de temperaturas de até $2^{\circ} \mathrm{C}$, reduzindo ainda mais a influência da vegetação com a ação dos ventos.

A superfície coberta com vegetação é a mais eficiente em transformar a energia. Assim quando maior a área de exposição das folhas, maior o efeito. Neste sentido os índices de área foliar $\mathrm{LAI}^{44}$ tem uma relação direta com a quantidade de luz, energia e consumo de $\mathrm{CO}_{2}$. Segundo Trowbridge e Bassuk (2004) uma copa de densidade média (LAI=4) tem uma perda média diária de água no período de verão de até 118 litros (31 galões). Sob a influência da vegetação, as diferenças na temperatura de superfície são maiores do que na temperatura do ar. Este fato depende do balanço de energia, principalmente da condutividade térmica entre a superfície e a camada de ar acima dela.

\subsection{PROPRIEDADES TÉRMICAS DAS FOLHAS}

Segundo Oke (1987), as propriedades radiativas das folhas dependem do comprimento de onda. Os valores da reflexão, transmissão e absorção são definidos pela estrutura interior das folhas e as propriedades radiativas dos principais pigmentos das plantas (clorofila e carotenóides ${ }^{45}$ ).

Estes pigmentos absorvem com maior intensidade nas faixas: azul $(0.40$ a $0.51 \mu \mathrm{m}) \mathrm{e}$ vermelha $(0.61$ a $0.70 \mu \mathrm{m})$ na parte visível do espectro eletromagnético e representam a principal faixa de comprimento de onda para realização do processo de fotossíntese. Neste sentido, a banda entre 0.40 e $0.70 \mu \mathrm{m}$ é denominada Photosyntetically active radiation - PAR e apresenta uma absorção de $85 \%$ da radiação, $9 \%$ de reflexão e $6 \%$ de transmissão (Oke, 1987).

A Tabela 2 mostra os coeficientes médios de absorção, reflexão e transmissão para quatro principais bandas de comprimento de onda: PAR, Near infra-red radiation -

\footnotetext{
44 Índice de Área Foliar (Leaf Area Index) é a relação da quantidade de folhas e sua distribuição ao longo da copa das árvores. Informação mais detalha sobre o conceito, aplicação e método de medição do LAI estão presentes no Capítulo 5 - Medições de Campo.

${ }^{45}$ Quando os carotenóides e as clorofilas estão na mesma folha, esta capta luz azul-esverdeada e azul. A luz refletida pela folha é verde, funcionando os carotenóides como um pigmento acessório. A energia luminosa captada pelos carotenóides é transferida para as clorofilas, que as usam na fotossíntese. Os carotenóides permanecem nas folhas mesmo quando a clorofila desaparece. Disponível em:

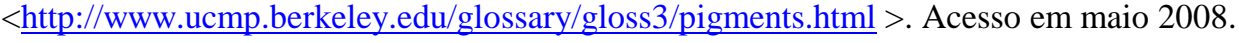


$\operatorname{NIR}^{46}(0.71-4.0 \mu \mathrm{m})$, radiação de onda curta $(0.35-3.0 \mu \mathrm{m})$ e radiação de onda longa (3.0- $100 \mu \mathrm{m})$. De acordo com os resultados, observa-se que a radiação solar de onda curta é absorvida pela folha em $50 \%$, sendo os valores da reflexão e da transmissão, $30 \%$ e $20 \%$, respectivamente.

Tabela 2: Coeficientes médios para absorção, reflexão e transmissão em quatro principais bandas de comprimento de onda.

\begin{tabular}{|c|c|c|c|c|}
\hline & $\begin{array}{l}\mathrm{PAR}^{\dagger} \\
(0.38-0.71 \\
\mu \mathrm{m}) \S\end{array}$ & $\begin{array}{l}\mathrm{NIR}^{\ddagger} \\
(0 \cdot 71-4 \cdot 0 \\
\mu \mathrm{m})\end{array}$ & $\begin{array}{l}\text { Short-wave } \\
(0.35-3.0 \\
\mu \mathrm{m}) \S\end{array}$ & $\begin{array}{l}\text { Long-wave } \\
(3 \cdot 0-100 \\
\mu \mathrm{m})\end{array}$ \\
\hline Reflection & 0.09 & 0.51 & $0 \cdot 30$ & 0.05 \\
\hline Transmission $(\Psi)$ & 0.06 & $0 \cdot 34$ & $0 \cdot 20$ & 0.00 \\
\hline Absorption & 0.85 & $0 \cdot 15$ & 0.50 & 0.95 \\
\hline
\end{tabular}

\section{Fonte: Ross (1975) apud Oke (1987).}

A reflexão depende do comprimento de onda, tipo da espécie, idade, superfície acima (atmosfera) e abaixo (solo), posição em relação à entrada da radiação, posição da copa, condições do ambiente (árido ou fértil), estação do ano e altitude. A transmissão pelas folhas depende da sua estrutura e espessura. De acordo com a espessura (variando para cada folha) as folhas tendem a ter as mesmas propriedades ópticas e térmicas (Holm, 1989).

A Figura 37 apresenta a relação entre o comprimento de onda e os valores de transmissão, reflexão e absorção na folha. Percebe-se que após a faixa PAR (a partir de $0.71 \mu \mathrm{m})$ a absorção é reduzida até o comprimento de $1.5 \mu \mathrm{m}$, favorecendo a reflexão e transmissão da radiação, uma vez que esta energia não contribui para o processo de fotossíntese.

\footnotetext{
${ }^{46}$ As ondas infravermelhas estão divididas em três regiões espectrais: próxima, média e distante. A próxima tem comprimento de 0.71 e $4.0 \mu \mathrm{m}$, a média está entre 5 e (25-40) $\mu \mathrm{m}$ e a distante entre (25-40) e (200-350) $\mu \mathrm{m}$. Disponível em: < http://www.ipac.caltech.edu/Outreach/Edu/Regions/irregions.html >. Acesso em maio de 2008.
} 


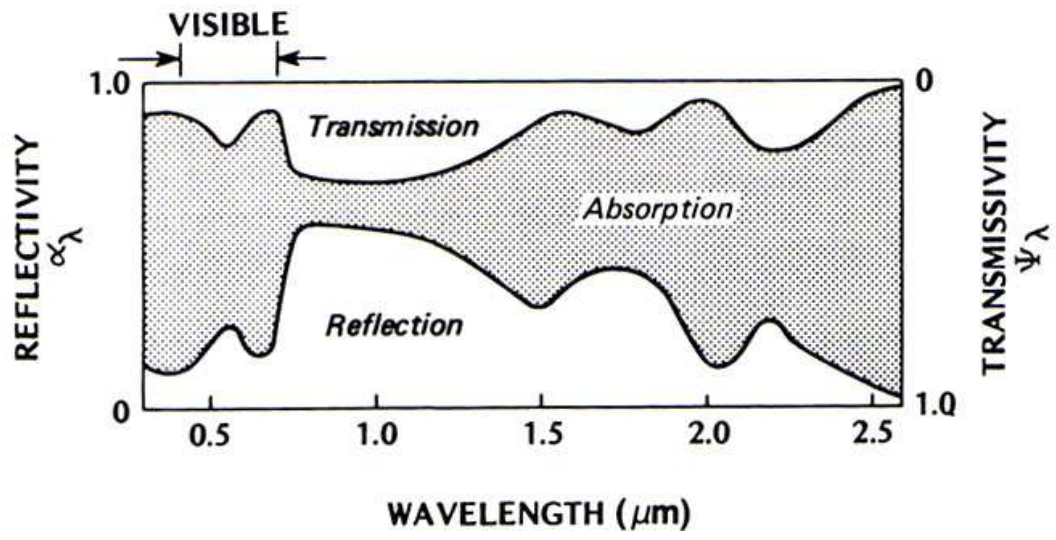

Figura 37: A relação entre o comprimento de onda e os valores de transmissão, reflexão e absorção.

\section{Fonte: Oke (1978) apud Monteith (1965).}

Segundo Ometo (1981), o balanço de radiação de uma folha é decorrente da posição que ela ocupa na copa, sendo, portanto, um parâmetro extremamente variável. Deve-se considerar que, além da posição, a idade, a estrutura e a coloração influenciam nos processo de absorção, reflexão e transmissão. $\mathrm{O}$ autor descreve os principais elementos que compõem o balanço de radiação para uma folha externa e interna:

- Uma folha disposta externamente à planta recebe em sua superfície superior radiação solar direta e difusa, como ondas curtas, e radiação atmosférica, como ondas longas. Por sua vez reflete parte desta radiação que sobre ela incide e emite radiação de ondas longas em função de sua temperatura e deixa que parte de sua radiação seja transmitida. Na superfície inferior, recebe radiação difusa e resultante do albedo do solo e das folhas vizinhas, como radiação de ondas curtas. Recebe radiação de ondas longas provenientes da emissão do solo e das folhas vizinhas e, por sua vez, reflete parte dessas radiações e emite radiação de onda longa.

- Se a folha se encontra no interior de uma planta, ela recebe como radiação de onda curta, em ambas as faces, somente a radiação solar difusa, além da radiação refletida pela superfície e pelas folhas vizinhas. A radiação de onda longa chega na forma de emissão atmosférica e das folhas vizinhas, refletindo parte dessa energia e também emitindo ondas longas em função de sua temperatura. 
Portanto, o balanço da radiação que acontece na parte superior e inferior da folha (Figura 38) é:

$\mathrm{Q}^{*}{ }_{\text {leaf }}=\left[\left(\mathrm{K}_{\mathrm{in}(\mathrm{t})}+\mathrm{K}_{\mathrm{in}(\mathrm{b})}\right)(1-\Psi-\alpha)\right]+\left[\left(\mathrm{L}_{\mathrm{in}(\mathrm{t})}-\mathrm{L}_{\mathrm{out}(\mathrm{t})}\right)+\left(\mathrm{L}_{\mathrm{in}(\mathrm{b})-} \mathrm{L}_{\mathrm{out}(\mathrm{b})}\right)\right]$

$\mathrm{Q}^{*}{ }_{\text {leaf }}=\mathrm{K}^{*}{ }_{(\mathrm{t})}+\mathrm{K}^{*}{ }_{(\mathrm{b})}+\mathrm{L}_{(\mathrm{t})}^{*}+\mathrm{L}^{*}{ }_{(\mathrm{b})}$

$\mathbf{Q}^{*}{ }_{\text {leaf }}=\mathbf{K}^{*}{ }_{\text {leaf }}+\mathbf{L}^{*}{ }_{\text {leaf }}$

Onde:

$\mathbf{K}_{\text {in(t) }}=$ Total da radiação que chega durante o dia (parte superior da folha).

$\mathbf{K}_{\text {in(b) }}=$ Total da radiação que chega durante o dia (parte inferior da folha).

$\mathbf{L}_{\mathbf{i n}(\mathbf{t})}=$ Total da radiação que chega durante a noite (parte superior da folha).

$\mathbf{L}_{\mathbf{i n}(\mathbf{b})}=$ Total da radiação que chega durante a noite (parte inferior da folha).

$\mathbf{L}_{\text {out(t) }}=$ Total da radiação que sai durante a noite (parte superior da folha).

$\mathbf{L}_{\text {out(b) }}=$ Total da radiação que sai durante a noite (parte inferior da folha).

$\boldsymbol{\Psi}=$ transmissão

$\boldsymbol{\alpha}=$ reflexão

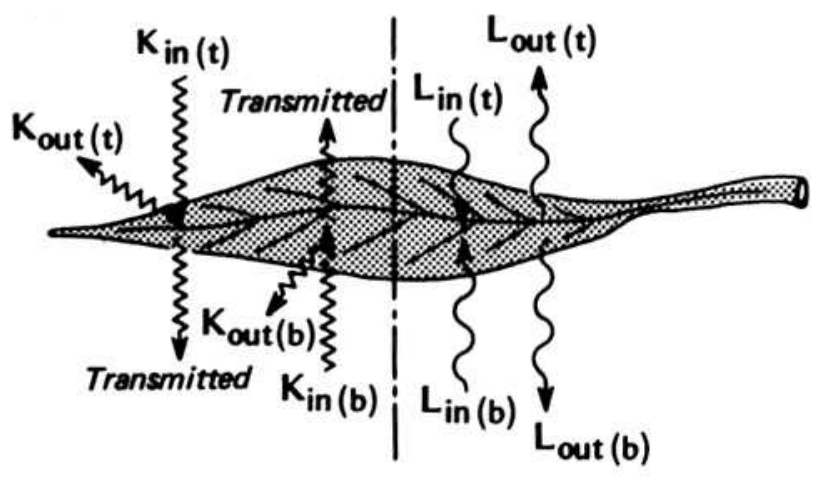

Figura 38: Balanço da radiação que acontece na parte superior e inferior da folha.

Fonte: Oke (1978).

As folhas desenvolveram alguns mecanismos para evitar o stress térmico em ambientes com temperaturas elevadas, por meio de altos valores de albedo ou da diminuição da área de superfície voltada para a direção dos raios solares. 
Altos valores de albedo reduzem a quantidade de radiação solar absorvida pelo material, mantendo a temperatura das superfícies mais frias. A redução da temperatura das superfícies diminui a emissão de radiação de onda longa para a atmosfera. Este fato tem um significativo impacto no consumo de energia para sistemas de ar condicionado, principalmente para cidades de clima quente (Taha, 1997).

O albedo de áreas vegetadas é um importante fator para regular a circulação atmosférica, sendo uma característica presente em muitos processos ecológicos como evapotranspiração e fotossíntese. O albedo da superfície é um parâmetro chave para as interações radiação solar-superfície e balanço energético (Yin, 1997).

Em pesquisa recente patrocinada pelo Departamento Americano de Energia (DOE) e a Agência de Proteção Ambiental (EPA), foram investigados os albedos de materiais como concreto e asfalto. Os resultados indicam que um asfalto novo tem albedo entre 0.05-0,10; o albedo do cimento cinza fica entre 0.35-0.40, enquanto o albedo do cimento branco é de 0.70-0.80 (American Concrete Pavement Association ${ }^{47}$ ).

Os valores de albedo para as folhas variam entre 0.25-0.30. No entanto, devem-se considerar algumas adaptações ecológicas para espécies em ambientes de climas quentes e secos, com baixos índices pluviométricos, que podem resultar em albedos mais elevados. Nos estudos em Atenas por Dimoudi e Nikolopoulou (2003), o albedo utilizado para as árvores decíduas foi de 0.30 , podendo-se definir 0.25 para árvores que não perdem as folhas.

A metodologia para se obter os valores de albedo de árvores é mais complexa do que para as superfícies de asfalto e demais pavimentos inertes, uma vez que a superfície da copa é irregular e depende da distribuição das folhas. Segundo Yin (1997), as principais metodologias para medição do albedo em plantas são:

- Estudos teóricos que têm como foco o comportamento da superfície em relação à geometria da copa e tendem a ter limitações na sua aplicabilidade devido ao uso de parâmetros específicos.

\footnotetext{
${ }^{47}$ Disponível em: $<$ http://www.lehighcement.com/Education/PDFs/Albedo\%20ACPA\%20Pavement\%20Reflectance\%20(R T3.05).pdf $>$ Acesso em junho de 2007.
} 
- Nos estudos descritivos o albedo é medido por pontos fixos no nível do solo, por vôos de avião ou por imagens de satélites. As medições no solo são mais confiáveis, uma vez que as imagens de satélite e de avião têm um controle limitado no seu campo de visão. As medidas são feitas em um único momento e podem apresentar erros.

- Além das duas metodologias citadas, existem modelos computacionais como o Radiation Transfer Model Intercomparison ${ }^{48}$ - RAMI (Pity et al. 2004) que simulam a refletância de copas heterogêneas de árvores e superfícies do solo, organizado pela Joint Research Centre - JRC em Ispra, Itália.

\subsection{BALANÇO DE ENERGIA DA FOLHA}

A equação que define o balanço de energia da folha está descrita a seguir (Oke, 1978):

$\mathrm{Q}^{*}{ }_{\text {leaf }}=\left(\mathrm{Q}_{\mathrm{H}(\mathrm{t})}+\mathrm{Q}_{\mathrm{H}(\mathrm{b})}\right)+\left(\mathrm{Q}_{\mathrm{E}(\mathrm{t})}+\mathrm{Q}_{\mathrm{E}(\mathrm{b})}\right)$

$Q^{*}{ }_{\text {leaf }}=Q_{H(\text { leaf })}+Q_{E}($ leaf $)$

Onde:

$\mathbf{Q}_{\mathbf{H}(\mathbf{t})}=$ Fluxo de Calor Sensível (parte superior da folha).

$\mathbf{Q}_{\mathbf{H}(\mathbf{b})}=$ Fluxo de Calor Sensível (parte inferior da folha).

$\mathbf{Q}_{\mathbf{E}(\mathbf{t})}=$ Fluxo de Calor Latente (parte superior da folha).

$\mathbf{Q}_{\mathbf{E}(\mathbf{b})}=$ Fluxo de Calor Latente (parte inferior da folha).

Esta equação não considera a taxa líquida de calor armazenado $\left(\Delta \mathrm{Q}_{S}\right)$ e a taxa líquida de calor bioquímico armazenado $\left(\Delta \mathrm{Q}_{\mathrm{P}}\right)$ por apresentar, em relação ao total da radiação, valores pequenos de $6 \mathrm{Wm}^{-2}$ (Monteith, 1973) e $16 \mathrm{Wm}^{-2}$, respectivamente (Oke, 1987). A fim de reduzir as cargas de calor recebidas durante o dia, as folhas contam com a ação dos ventos para diminuir os ganhos de calor sensível $\left(\mathrm{Q}_{\mathrm{H}}\right)$ e a evaporação $(\mathrm{E})$ da água pelos estômatos.

\footnotetext{
${ }^{48}$ Disponível em: < http://rami-benchmark.jrc.it/HTML/Home.php〉. Acesso em junho de 2007.
} 
A transferência de calor sensível tem a seguinte representação:

$\mathbf{Q}_{\mathrm{H}}=\mathbf{C}_{\mathrm{a}}\left(\mathbf{T}_{\mathbf{o}}-\mathbf{T}_{\mathrm{a}}\right) / \mathbf{r}_{b}$

Onde:

$\mathbf{Q}_{\mathbf{H}}=$ Fluxo de Calor Sensível (parte superior da folha).

$\mathrm{Ca}=$ Capacidade térmica do ar

$\mathbf{T}_{\mathbf{0}}=$ Temperatura da superfície da folha

$\mathbf{T}_{\mathbf{a}}=$ Temperatura do ar

$\mathbf{r}_{\boldsymbol{b}}=$ resistência do Laminar Bondary Layer.

O Laminar Boundary Layer é a camada logo acima da folha, exercendo resistência para a ação do vento. $O$ valor de $\mathbf{r}_{b}$ aumenta com tamanho da folha, pois a camada do Laminar Boundary Layer aumenta proporcionalmente com a distância (Figura 39), poucos ventos e a redução na diferença da temperatura entre o ar e a superfície da folha.

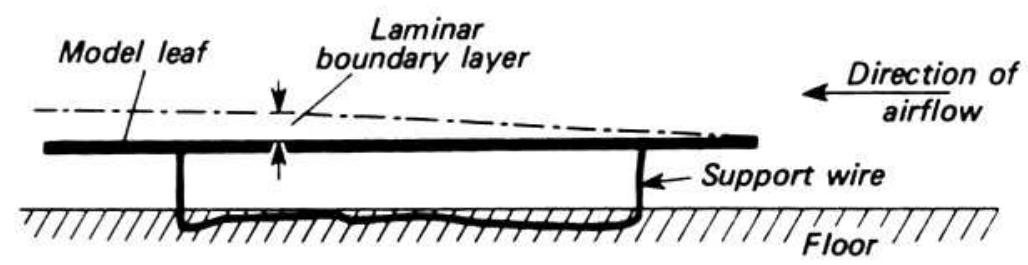

Figura 39: Laminar Boundary Layer sobre a folha.

Fonte: Oke (1978).

A evaporação também colabora na redução das cargas de calor, sendo um fenômeno físico de mudança da fase líquida para vapor da água presente em condições naturais, necessitando de uma energia equivalente a 590 calorias disponíveis a cada grama de água pura, quando esta se encontra na condição de zero grau centígrado e a uma atmosfera de pressão. A fonte quase exclusiva da energia consumida na evaporação natural da água é a radiação solar (Ometo, 1981).

O conceito teórico de evaporação das águas pelas plantas e solo foi elaborado por H.L. Penman no período de 1942-1943. Em seus estudos, o autor buscava prever a umidade 
da superfície do solo sem precisar da medição direta em campo, e a abordagem inicial usou o balanço de energia da superfície de evaporação e a radiação solar como principal fonte de calor. No entanto, a influência dos ventos não entrou como parâmetro na equação (Karvonen $\left.{ }^{49}, 2003\right)$.

A equação que descreve a evaporação de uma superfície, segundo Penman (1948) é:

$\mathbf{E}=(\Delta \mathbf{H} / \mathbf{5 9}+\gamma \mathbf{E a}) /(\Delta+\gamma)$

Onde:

$\Delta=$ Tangente da curva de tensão de vapor d'água.

H/ 59 = Radiação líquida disponível em milímetros de evaporação equivalente.

$\gamma=$ Constante psicrométrica

$\mathbf{E a}=$ Déficit de saturação

Mais tarde essa equação sofreu modificações por Monteith (1965) que inseriu o efeito da resistência dos estômatos. A equação final de Penman-Monteith para o cálculo da evaporação potencial:

$\mathbf{E}=\left[\boldsymbol{\sigma} \times \mathbf{c}_{\mathrm{p} \times}\left(\mathbf{e}_{\mathrm{s}}-\mathbf{e}_{\mathrm{a}}\right)\right] /\left[\gamma \times\left(\mathbf{r}_{\mathrm{s}}+\mathbf{r}_{\mathrm{a}}\right)\right]$

Onde:

$\boldsymbol{\sigma}=$ Densidade do ar

$\mathbf{c}_{\mathbf{p}}=$ Calor específico do ar

$\mathbf{e}_{\mathbf{s}}=$ Umidade relativa nos estômatos

$\mathbf{e}_{\mathbf{a}}=$ Umidade relativa do ar

$\gamma=$ Constante psicrométrica

$\mathbf{r}_{\mathbf{s}}=$ Resistência dos estômatos

$\mathbf{r}_{\mathbf{a}}=$ Resistência da superfície em relação à atmosfera

\footnotetext{
${ }^{49}$ Disponível em: < http://www.water.tkk.fi/wr/kurssit/Yhd-12.135/kirja/evapo.htm >. Acesso em maio 2008.
} 
Em uma abordagem mais direta, Oke (1987) considerou a evaporação como uma relação da densidade de vapor saturado com a resistência estomática existente entre o ar e a cavidade interna dos estômatos. Assim, a equação que define esta relação tem a seguinte representação:

$\mathbf{E}=\left(\boldsymbol{\rho}_{\mathrm{v}(\mathrm{To})}-\boldsymbol{\rho}_{\mathrm{va}}\right) /\left(\mathbf{r}_{b}+\mathbf{r}_{\mathrm{st}}\right)$

Onde:

$\boldsymbol{\rho}_{\mathbf{v}(\mathbf{T o})}=$ Densidade de vapor saturado na superfície da folha

$\boldsymbol{\rho}_{\mathbf{v a}}=$ Densidade do ar

$\mathbf{r}_{b}=$ Resistência do Laminar Bondary Layer.

$\mathbf{r}_{s t}=$ Resistência dos estômatos

De acordo com a equação 7 , percebe-se que a taxa de evaporação é proporcional à densidade de vapor saturado na superfície da folha, isto é, quanto mais saturado estiver o ar, menor será a perda de água pela superfície da folha. Além disso, a resistência dos estômatos é fundamental no processo de evapotranspiração, sendo representado pela seguinte equação (Jacobs, 1994):

$$
\mathbf{r}_{s t}=1 / g_{\mathrm{s}} \times 1000
$$

Sendo a variável $\mathbf{g}_{\mathbf{s}}$ descrita da seguinte forma:

$$
g_{s}=1.6 \times A_{n} / C_{s} C_{i}
$$

Onde:

$\mathbf{A}_{\mathbf{n}}=$ taxa de fotossíntese

$\mathbf{C}_{\mathbf{s}}=$ concentração de $\mathrm{CO}_{2}$ na superfície da folha

$\mathbf{C}_{\mathbf{i}}=$ concentração de $\mathrm{CO}_{2}$ dentro da folha

O cálculo da resistência estomática mostra que o comportamento dos estômatos é diretamente influenciado por várias condições ambientais externas e fatores da própria 
planta (Jacobs, 1994). Entre os fatores externos estão: $\mathrm{CO}_{2}$, luz, temperatura (ar, solo), umidade de saturação do ar, umidade do solo, concentração de ar no solo e poluição (ar, solo). Por sua vez, os fatores internos da planta são: temperatura da folha, quantidade de água, tipos de hormônios, idade da folha, estágio de desenvolvimento e condições de crescimento. A figura 40 mostra como o seu funcionamento permite as trocas gasosas de $\mathrm{CO}_{2}$ e vapor d'água.

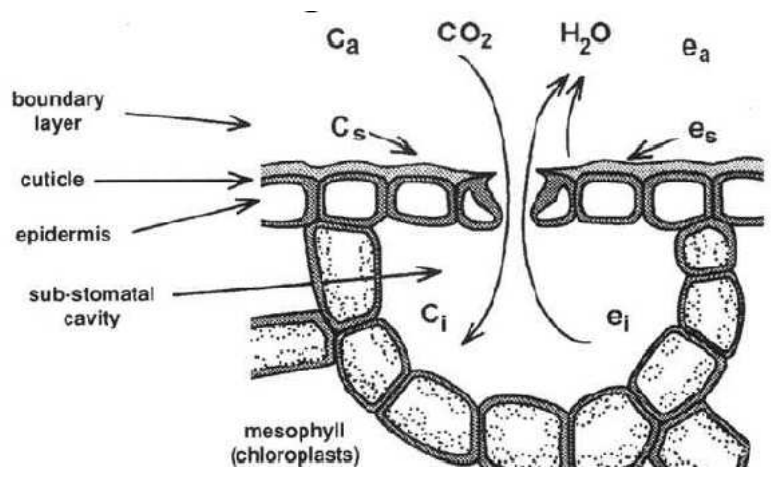

Figura 40: Trocas gasosas pela abertura dos estômatos na superfície da folha.

Fonte: Oke (1978).

A abertura dos estômatos estimula o processo de trocas gasosas entre a folha e o ar, podendo o fechamento parcial ou total impedir o estresse da planta por déficit de água no solo. A resistência dos estômatos cresce quando a temperatura da folha aumenta ou diminui em relação à temperatura do ar de $25^{\circ} \mathrm{C}$ (Dimoudi e Nikolopoulou, 2000). A figura 41 mostra a distribuição dos estômatos nas folhas, sendo que a densidade dos estômatos varia de 300 a 800 estômatos/mm (Rowland e Bamford et.al., 1990, Woodward 1987, Kimball et.al., 1986).


Figura 41: Presença de estômatos nas folhas (fotos: P. Shinzato) 


\subsection{PROPRIEDADES TÉRMICAS DAS ÁRVORES}

Segundo McClenon, (1983), uma árvore absorve em média de 60 a 90\% da energia solar total, podendo variar de acordo com a densidade e tipo de folha. Uma árvore densa chega a absorver de $75-80 \%$ da radiação solar, transmitir 5\% e refletir de $15-20 \%$ (Geiger, 1983).

A radiação de onda longa ocorre entre 3 a $100 \mu \mathrm{m}$ e depende basicamente da temperatura das superfícies no entorno. Durante o dia, as sombras das árvores reduzem o ganho de calor pela radiação de onda longa para as fachadas dos edifícios e pela radiação de onda curta para o solo. No período noturno, as temperaturas próximas ao solo são mais baixas, devido ao efeito do sombreamento durante o dia, resultando em uma redução na carga de radiação liberada pelas superfícies (Dimoundi e Nikolopoulou, 2003).

As camadas de folhas mais externas na superfície da copa atuam como um filtro, enquanto as camadas internas têm a função de um material isolante. Uma vez que as copas apresentam espessuras maiores que $1.5 \mathrm{~m}$, a característica de isolante torna-se dominante (Holm, 1989).

Segundo Campbell (1977), durante o dia, a temperatura da folhas é maior que a temperatura do ar. Se houve ventos fortes e pequena entrada de radiação (dia nublado), a transpiração pode reduzir a temperatura da folha em relação à temperatura do ar. No entanto, a condição de ventos calmos e um forte ganho por radiação solar direta pode aumentar a temperatura da folha entre $9^{\circ} \mathrm{C}$ e $11^{\circ} \mathrm{C}$, mesmo considerando que a elevada temperatura cause uma redução na transpiração, gerando um resfriamento significativo.

O balanço positivo da radiação causa o aumento da temperatura das folhas em relação ao ar; por outro lado, o balanço negativo gera a diminuição da temperatura, dependendo de dois fatores: as trocas realizadas entre a atmosfera e o processo de evapotranspiração (Geiger, 1983). A diminuição nos ganhos de radiação durante a noite resulta em uma redução na temperatura da folha em relação ao ar de $2-3^{\circ} \mathrm{C}$.

O processo de evapotranspiração compreende a perda associada de água, que ocorre pela evaporação da superfície do solo e pela transpiração estomática e cuticular da 
planta. A equação que descreve o cálculo da evapotranspiração é (Penman- Monteith, 1965):

$$
L E=\frac{\left[\operatorname{SRn}+\sigma \operatorname{cp}\left(\mathbf{e}_{\mathrm{d}}-\mathbf{e}_{\mathrm{a}}\right) / \mathbf{r}_{\mathrm{a}}\right]}{\mathrm{S}+\gamma\left(1+\mathbf{r}_{\mathrm{s}} / \mathbf{r}_{\mathrm{a}}\right)}
$$

Onde:

$\mathbf{S}=$ Taxa de mudança da saturação da umidade específica com a temperatura do ar

$\mathbf{R n}=$ Radiação Global

$\boldsymbol{\sigma}=$ Densidade do ar

$\mathbf{c}_{\mathbf{p}}=$ Calor específico do ar

$\mathbf{e}_{\mathbf{d}}=$ Umidade relativa nos estômatos

$\mathbf{e}_{\mathbf{a}}=$ Umidade relativa do ar

$\gamma=$ Constante psicrométrica

$\mathbf{r}_{\mathrm{s}}=$ Resistência dos estômatos

$\mathbf{r}_{\mathbf{a}}=$ Resistência da superfície em relação à atmosfera

Segundo Oke (1978), o balanço de radiação de uma planta é um processo mais complexo do que o cálculo para uma única folha, pois mesmo que a superfície da árvore seja o principal local para as trocas de calor, existe uma significativa absorção, reflexão e transmissão na parte interna da copa. A transmissão da radiação de onda curta pela copa das árvores é em geral calculada com base na lei de Beer que descreve a relação entre quantidade disponível de luz e índice de área foliar - $\mathrm{LAI}^{50}$, sendo:

$$
\mathbf{A L}=\mathrm{e}^{-\mathbf{L A I} k}
$$

Onde:

$\mathbf{A L}=$ a luz que chega no ponto $\mathrm{i}$

$\mathbf{i}$ = ponto localizado a uma determinada altura do solo. Por exemplo, $\mathrm{i}=20$ significa $20 \mathrm{~m}$ acima do solo.

\footnotetext{
${ }^{50}$ O Índice de Área Foliar está descrito com mais detalhes no item 5.2: Medições do Índice de Área Foliar - LAI
} 
$\mathbf{e}=$ base para um logaritmo natural.

A equação 11 mostra que a quantidade luz varia segundo a altura na copa e a quantidade de folhas. O ângulo das folhas também influencia na quantidade de luz que chega ao solo. Em florestas decíduas temperadas ( $\mathrm{LAI}=3-5)$, a quantidade de luz que chega ao solo, após passar pela copa, é de 1.0-5.0\%; em florestas de pinheiros (LAI = 2-4) o valor é de $10-15 \%$; e em florestas tropicais (LAI =6-10), entre $0.25-2.0 \%$.

O albedo da vegetação costuma ser menor do que o albedo para folhas individuais, pois a reflexão depende não apenas das propriedades radiativas dos componentes da superfície, mas variam de acordo com forma da copa e o ângulo de incidência do sol. Estes dois últimos controlam a quantidade de penetração, radiação retida no interior e sombreamento mútuo entre as copas (Oke, 1978).

A Figura 42 mostra a relação entre o albedo da vegetação e sua altura. Observa-se que para plantas com altura de $50 \mathrm{~cm}$ o albedo é de 0.26 , ao invés de 0.30 obtido para uma única folha. Em árvores com $5 \mathrm{~m}$ de altura, o albedo diminui para 0.20.

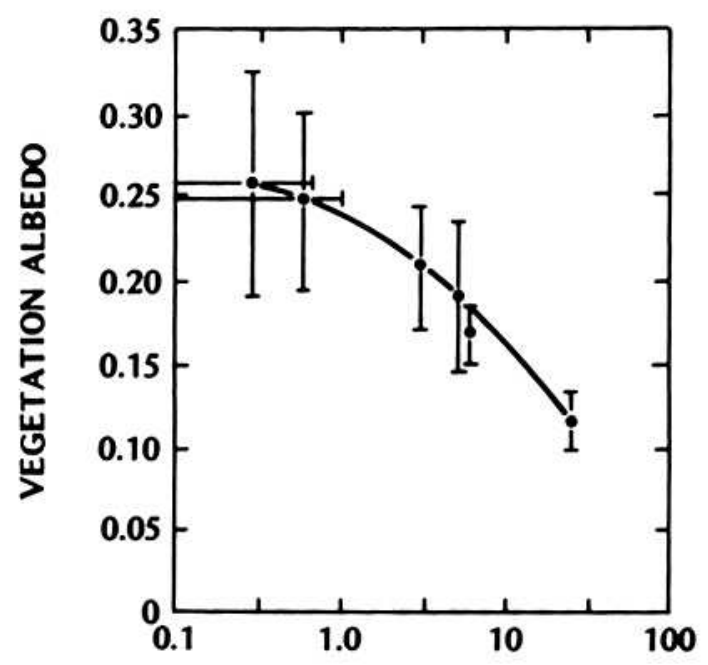

Figura 42: Relação entre o albedo da vegetação e sua altura.

Fonte: Oke (1978) 


\subsection{BALANÇO DE ENERGIA DA VEGETAÇÃO}

A equação que define o balanço de energia da vegetação está descrita a seguir (Oke, 1978):

$\mathbf{Q}^{*}=\mathbf{Q}_{\mathbf{H}}+\mathbf{Q}_{\mathbf{E}}+\Delta \mathbf{Q}_{\mathbf{S}}+\Delta \mathbf{Q}_{\mathbf{P}}$

Onde:

$\mathbf{Q}_{\mathbf{H}}=$ Fluxo de calor sensível

$\mathbf{Q}_{\mathbf{E}}=$ Fluxo de calor latente

$\Delta \mathbf{Q}_{\mathrm{S}}=$ Taxa líquida do calor físico armazenado pelas substâncias do sistema.

$\Delta \mathbf{Q}_{\mathbf{P}}=$ Taxa líquida de calor bioquímico armazenado

A taxa de calor físico armazenado muda os valores de absorção e emissão de calor pelo ar, solo e planta (folhas, galhos, tronco). A taxa de calor bioquímico armazenado ocorre pelo processo de fotossíntese das plantas, mudando os valores de acordo com a taxa de $\mathrm{CO}_{2}$ assimilado pela vegetação. Dependendo da natureza do ambiente de entorno podese adicionar o termo $\Delta \mathbf{Q}_{\mathbf{A}}$ sobre a ação dos ventos que considera a energia de ganhos e perdas pelo transporte horizontal do calor sensível e latente.

Além do balanço de energia é importante considerar o balanço hídrico que contabiliza toda a água envolvida entre os sistemas solo, planta e atmosfera, podendo oferecer a qualquer instante a quantidade de água disponível contida em um perfil de solo prédeterminado (Ometo, 1981).

Os parâmetros que definem o balanço hídrico estão descritos a seguir (Ometo, 1981):

$\mathbf{P}+\mathbf{I}+\mathbf{E t}+\Delta \mathbf{M}+\mathbf{F}+\mathbf{D}=\mathbf{0}$

Onde:

$\mathbf{P}=$ Precipitação

I= Irrigação

$\mathbf{E t}=$ Evapotranspiração

$\Delta \mathbf{M}=$ Variação de armazenamento de água no perfil considerado 
$\mathbf{F}=$ Deflúvio superficial para o terreno inclinado

$\mathbf{D}=$ Drenagem profunda

Uma vez que o armazenamento de água ocorre, em $80 \%$ dos casos, na camada onde se situa o sistema radicular da planta, a drenagem profunda é contabilizada como excesso e não precisa ser considerada.

Oke (1978) descreve de forma mais simplificada o balanço hídrico a partir da equação do balanço de energia para a vegetação:

$p=\mathbf{E}+\Delta r+\Delta s$

Onde:

$\boldsymbol{p}=$ Balanço hídrico

$\mathbf{E}=$ Evapotranspiração

$\Delta \boldsymbol{r}=$ Deflúvio superficial

$\Delta s$ = Água total armazenada no ar (umidade), planta (interceptação das chuvas pela vegetação) e solo.

A Figura 43 mostra a interação entre os parâmetros considerados para o balanço de energia da vegetação e balanço hídrico do mesmo sistema.
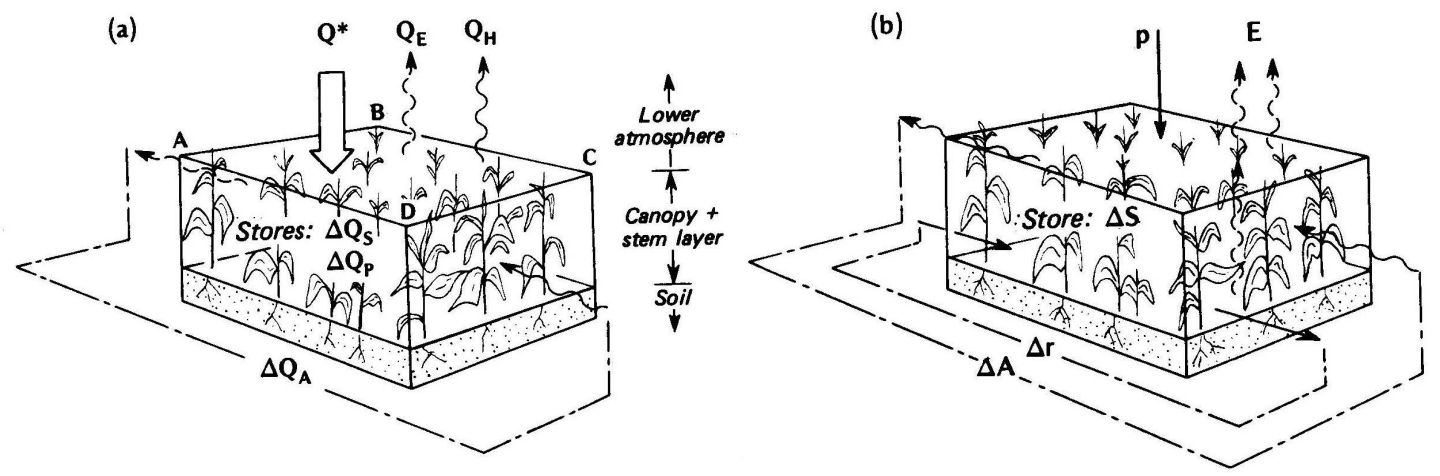

Figura 43: Fluxo esquemático envolvendo o balanço de energia da vegetação (a) e o balanço hídrico para o volume ar-planta- solo (b).

Fonte: Oke (1978). 


\subsection{MODELOS QUE SIMULAM O IMPACTO DA VEGETAÇÃO SOBRE O MICROCLIMA}

Segundo Jansson (2006), os mais utilizados modelos 1D para áreas urbanas são os de transferência de energia que calculam o fluxo acima da subcamada de rugosidade ${ }^{51}$, como por exemplo, Town Energy Balance - TEB de Masson (2000), o Local-Scale Urban Meteorological Parameterization Scheme - LUMPS por Grimmond e Oke (2002), FMV por Martelli et al. (2002).

O modelo Town Energy Balance - TEB simula os fluxos turbulentos em áreas urbanas e calcula o balanço de energia das superfícies (paredes, ruas, telhados), uma vez que incorpora representações do tecido urbano, geometria dos canyons, além de permitir a adição de bases de dados climáticas e de radiação (Masson, 2002). Em seus estudos, autor aplicou o programa em duas áreas: o centro histórico da Cidade do México com edifícios de seis andares e fachada de pedra; e um centro industrial na cidade de Vancouver, Canadá, com galpões térreos.

Os resultados indicaram que dois terços da radiação total são armazenados ao longo do dia, tendo um fluxo turbulento de calor sensível à medida que o calor é liberado no período noturno. Os valores de temperatura superficial estão próximos das medições feitas nas duas áreas.

O Programa LUMPS (Grimmond e Oke, 2002) baseia-se em uma série de equações interligadas que permitem o cálculo do armazenamento de calor e do fluxo de calor sensível e latente, por meio das informações sobre a radiação total, das características da superfície (vegetação, edifícios, materiais impermeáveis) e da morfologia (rugosidade do tecido urbano, densidade e altura). A área de estudo é definida pelo LUMPS como uma "caixa" de comprimento entre 100 a 10000 metros, nas duas dimensões, com altura aproximada de 102-104 m denominada Surface Layer e que contém o Urban Canopy Layer, Roughnes Sublayer e Inercial Sublayer (Figura 44).

\footnotetext{
51 Subcamada de rugosidade (roughness sublayer) é a mais baixa camada atmosférica, apresentando elementos de rugosidade do tecido urbano como árvores e prédios. A camada inicia-se na superfície do solo e pode se estender por duas até cinco vezes a altura dos elementos rugosos (Rotach, 1999).
} 


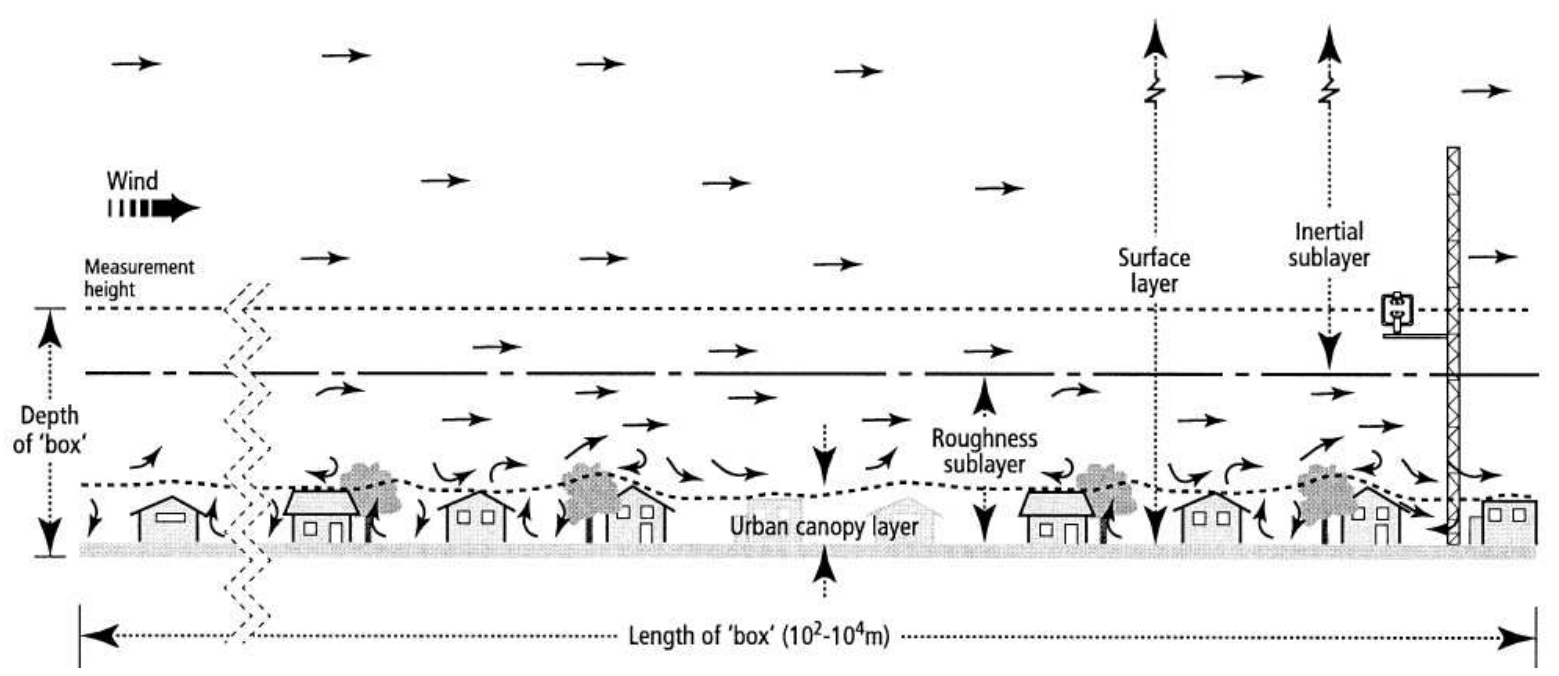

Figura 44: Características da escala local determinada pelo modelo LUMPS.

Fonte: Grimmond e Oke (2002).

O cálculo do balanço de energia segue a equação:

$\mathbf{Q}^{*}=\mathbf{Q}_{\mathrm{H}}+\mathbf{Q}_{\mathrm{E}}+\Delta \mathbf{Q}_{\mathbf{S}}$

Onde:

Q* = Radiação Total

$\mathbf{Q}_{\mathbf{H}}=$ Fluxo de Calor Sensível

$\mathbf{Q}_{\mathbf{E}}=$ Fluxo de Calor Latente

$\Delta \mathbf{Q}_{\mathrm{s}}=$ Fluxo de Calor Armazenado

O modelo FMV (Martelli et al.,2002). descreve as trocas dinâmicas e termodinâmicas na superfície das áreas urbanas, o autor desenvolveu estudos na cidade de Atenas, Grécia, a fim de comparar a qualidade das simulações com métodos mais tradicionais.

Apesar de realizarem o balanço de energia satisfatório para as áreas urbanas, estes três modelos citados estimam os fluxos de mesoescala, generalizando as características do tecido urbano e da vegetação.

Por outro lado, existem modelos 1D que calculam o efeito da vegetação com mais detalhes, como por exemplo, o CoupModel (Jansson e Moon, 2001), baseado no 
transporte de vapor de água e calor. A parte mais importante do modelo descreve o transporte vertical de água e calor entre as camadas do solo, mostrando a interação do sistema solo - vegetação - atmosfera com diferentes propriedades em cada elemento. $\mathrm{O}$ efeito da vegetação é calculado por meio da abordagem de Penman-Monteith que define a transpiração das árvores segundo a equação (Monteith, 1965):

$$
\begin{aligned}
T= & \underline{S}\left(\mathbf{R}_{\underline{n}}-\mathbf{G}\right)+M \underline{\rho}_{a} \underline{C p} \underline{D}_{a} \underline{\mathbf{r}_{a}} \underline{\underline{a}} \\
& \lambda\left[\mathbf{S}+\gamma\left(1+\mathbf{r}_{\mathrm{s}} / \mathbf{r}_{\mathbf{a}}\right)\right.
\end{aligned}
$$

Onde:

S: Declividade da curva de pressão de saturação do ar à temperatura do ar $\boldsymbol{t}$

$\mathbf{R}_{\mathbf{n}}:$ : Balanço de radiação

G: Fluxo de calor do solo

M: Fator de ajuste de escala

$\boldsymbol{\rho}_{\mathbf{a}}$ : Densidade média do ar

Cp: Calor específico do ar

$\mathbf{D}_{\mathbf{a}}$ : Déficit de pressão do vapor de água no ambiente

$\mathbf{r}_{\mathrm{s}}$ : Resistência dos estômatos

$\mathbf{r}_{\mathbf{a}}$ : Resistência aerodinâmica

$\lambda$ : Calor Latente de vaporização

$\gamma$ : Constante psicrométrica

Shashua e Hoffman (2002) criaram o modelo The Green CTTC Model para quantificar o efeito da vegetação na temperatura do ar e estimar o efeito do resfriamento passivo através da sombra das árvores nas ruas de Tel-Aviv, Israel. Este modelo analítico baseia-se nos princípios do Cluster Thermal Time Constant Model (CTTC) com novos parâmetros para a superfície das fachadas e o sombreamento das árvores.

Segundo Williamson e Erell (2001), apesar de o modelo CTTC apresentar resultados satisfatórios para a temperatura do ar, existem algumas restrições no que se refere: 
- Às condições climáticas de céu aberto e ventos moderados.

- À homogeneidade espacial dos edifícios e da superfície.

- Aos processos térmicos que ocorrem na cobertura e que não contribuem em variações na temperatura do ar ao longo do dia na camada de cobertura urbana, Urban Canopy Layer (do solo ao nível médio das coberturas).

- Aos efeitos da vegetação que não estão inclusos.

- Ao fato de que não existe influência do calor antropogênico na camada de cobertura urbana, Urban Canopy Layer.

No modelo Green CTTC, a temperatura do ar resultante da geometria urbana considera as fontes externas como radiação solar total, a emissão do calor antropogênico e o efeito da vegetação. A equação simplificada para obter a temperatura do ar em um determinado tempo $(\mathrm{t})$ é:

$T(t)=T o+\ddot{A} T_{\text {SOLAR }}(t)-\ddot{A} T_{N L W R}(t)-\ddot{A} T_{G R E E N}(t)+\ddot{A} T_{A H R}(t)$

Onde:

To = temperatura média diária medida em uma Estação Meteorológica representativa.

$\ddot{\mathbf{A}} \mathbf{T}$ SOLAR $(\mathbf{t})=$ contribuição da radiação solar direta para a variação de temperatura.

$\ddot{\mathbf{A}} \mathbf{T}_{\text {NLWR }}(\mathbf{t})=$ contribuição do fluxo de radiação de onda longa para o resfriamento do ar.

$\ddot{\mathbf{A}} \mathbf{T}_{\text {GREEN }}(\mathbf{t})=$ contribuição do resfriamento da vegetação para a temperatura do ar.

$\ddot{\mathbf{A}} \mathbf{T}_{\mathrm{AHR}}(\mathbf{t})=$ contribuição do calor antropogênico para a temperatura do ar.

O valor de $\ddot{A}_{\text {GREEN }}(\mathrm{t})$ é estimado considerando-se o efeito da penetração da radiação solar e o processo de evapotranspiração. Por exemplo, a espécie arbórea Ficus sp reduz em média $40 \%$ da radiação solar total incidente na copa da árvore (Shashua e Hoffman, 2002).

O modelo Green CTTC criado por Shashua-Bar e Hoffman (2002) proporciona a simulação do efeito da vegetação no ambiente urbano, porém tem como limitações as 
restrições na geometria da modelagem, permitindo o desenho de um canyon simples e oferece como dados de saída apenas a temperatura do ar (Johansson, 2006).

O laboratório Centre de Recherche Méthodologique d'Architecture - CERMA ${ }^{52}$ realizou o estudo da vegetação urbana por meio do modelo computacional SOLENE (Miguet, 1998). Este programa gera cálculos para temperatura de superfície e trabalha em conjunto com outro modelo, o N3S para simulação dos fluxos de vento e temperatura do ar. O comportamento térmico da vegetação segue a equação definida por PenmanMonteith:

$$
\mathbf{E P}^{*}=\Delta \mathbf{H} / \mathbf{5 9}+\gamma \mathbf{E a}
$$

$$
\Delta+\gamma
$$

Onde:

EP* = evapotranspiração de uma superfície livre de água em milímetros

H/59 = radiação líquida disponível em milímetros de evaporação equivalente

$\gamma=$ constante psicrométrica

$\Delta=$ mudança da pressão de vapor saturado com a temperatura $\left(\mathrm{kPa} \mathrm{K}^{-1}\right)$

$\mathbf{E a}=$ Parcela evaporativa em função do vento e déficit de saturação

Nos dias de céu claro e radiação solar alta, os estômatos se fecham, bloqueando a evapotranspiração nas folhas. Este fato resulta no aumento da temperatura de superfície da folha (Vinet et al., 2000).

Os trabalhos de Dimoudi e Nikolopoulou (2000) tratam da vegetação como um parâmetro que influencia as características do clima urbano. A investigação do efeito da vegetação foi realizada inicialmente por meio do programa Mathematical Plant: Transpiration, criado por Terence Murphy da Universidade da Califórnia, Davis. Este modelo calcula a taxa de transpiração da planta, o balanço de energia, a disponibilidade de água, as mudanças na temperatura da folha e a abertura dos estômatos. Sua

\footnotetext{
${ }^{52}$ Escola de Arquitetura de Nantes, França.
} 
importância está em se verificar a influência de diferentes parâmetros microclimáticos em áreas vegetadas.

Numa segunda fase, foram feitos estudos paramétricos com o programa CFD PHOENICS a fim de se investigar o impacto no conforto térmico e redução da temperatura do ar por meio da presença de vegetação nas ruas de Atenas, Grécia.

Mills (1997) desenvolveu um modelo para simular diferentes características térmicas na camada de cobertura urbana, Urban Canopy Layer (UCL). Em contraste com outros modelos, este programa inclui volumes fechados (edifícios) e abertos (canyons). A proposta deste modelo é comparar os impactos climáticos de acordo com diferentes configurações espaciais.

De acordo com Williamson e Erell (2001), Mills (1997) e Bruse (1998) discutem dois modelos preditivos que descrevem o impacto de um grupo de edifícios no microclima urbano. O modelo de Mills permite a configuração de diferentes agrupamentos de edifícios e densidades. O modelo ENVI-met, criado por Bruse, analisa o efeito das mudanças em pequena escala no desenho urbano com a inserção de novos materiais e vegetação.

O programa ENVI-met está detalhado no capítulo seguinte e foi utilizado nos estudos experimentais deste trabalho, simulando os efeitos da vegetação a partir de modelos paramétricos. O programa possibilitou criar modelos preditivos e avaliar o potencial microclimático das áreas verdes de acordo com o clima local.

\subsection{RELEVÂNCIA DO ENVI-MET PARA ESTA PESQUISA}

O modelo ENVI-met foi adotado nesta pesquisa por apresentar vantagens em relação a outros modelos numéricos de simulação climática. Primeiramente, o modelo é um dos poucos que permite a colocação da vegetação na modelagem do tecido urbano e considera a fisiologia das árvores nos cálculos de balanço de energia, na temperatura do ar e superficial (Ali-Toudert, 2005).

O modelo tem uma interface simplificada que permite organizar os dados de entrada com mais eficiência, não exigindo um conhecimento muito aprofundado em simulação computacional. Por outro lado, exige um conhecimento mais preciso das informações sobre climatologia urbana a fim de se obter resultados próximos da realidade 
(Johansson, 2006). O programa exige poucos dados de entrada e oferece mais de quarenta opções de dados de saída (Ali-Toudert, 2005).

A escala da modelagem gerada pelo ENVI-met possibilita inserir diferentes desenhos urbanos, devido à resolução espacial de cada célula da grade ter o valor mínimo de $1 \mathrm{~m} \mathrm{x}$ 1m. Este fato possibilita um detalhamento da modelagem de acordo com as necessidades espaciais do projeto a ser avaliado.

Apesar de existirem outros modelos, como mostra este capítulo anterior, o ENVI-met é uma ferramenta acessível aos pesquisadores em conforto ambiental urbano, sendo o modelo mais conhecido que faz a interação superfície-vegetação-atmosfera e considera não apenas o efeito de sombreamento das árvores, mas também o processo fisiológico de fotossíntese e abertura dos estômatos. 


\section{APLICAÇÕES DO MODELO ENVI-MET NESTA PESQUISA}

\subsection{O MODELO ENVI-MET 3.0}

O modelo computacional a ser utilizado durante a pesquisa é o ENVI-met ${ }^{53}$, um modelo tridimensional para simular as interações entre superfície-vegetação-atmosfera. $\mathrm{O}$ objetivo é analisar, numa perspectiva de micro-escala, a interação entre o desenho urbano e o microclima.

No intuito de se avaliar os benefícios da vegetação, Bruse (1998) implementou computacionalmente esse modelo numérico para o cálculo dos principais fatores relacionados à vegetação: transpiração, evaporação, fluxo de calor sensível, fluxos turbulentos de calor e vapor; resistência dos estômatos, balanço energético da folha e balanço de água do sistema solo-vegetação.

O modelo calcula o balanço de energia para ondas curtas e longas por meio das variáveis: radiação, reflexão de edifícios e vegetação, fluxo do ar, temperatura, umidade, turbulência local e sua taxa de dissipação. Também determina as temperaturas de superfície (pisos e envoltória dos edifícios), as trocas de água e calor no solo e parâmetros biometeorológicos, como a temperatura efetiva e o Predicted Mean Vote PMV (Fanger, 1972).

Em relação à vegetação, este modelo determina a temperatura média nas folhas por meio do cálculo do balanço térmico que considera a condição climática e fisiológica da planta. O cálculo do fluxo de radiação inclui sombreamento, absorção e reemissão da radiação por outras partes da planta.

A Tabela 3 mostra os principais aspectos relacionados à arquitetura e o ambiente externo que o ENVI-met se propõe a calcular. Trata-se, portanto, de um modelo complexo que busca visualizar o comportamento de um ambiente (interno ou externo) por meio de diferentes condições climáticas e arquitetônicas.

53 Este programa é gratuito e está disponível em http://www.geographie.ruhr-unibochum.de/agklima/envimet/. Acesso em agosto de 2007. 
Tabela 3: Principais Variáveis utilizadas pelo ENVI-met.

\begin{tabular}{|c|c|c|c|c|c|}
\hline Atmosphere & Soil System & Vegetation & Surfaces & Biometeorology & $\begin{array}{l}\text { Behind the } \\
\text { scenes }\end{array}$ \\
\hline Wind & Temperature & Foliage & Ground Surface & \multirow{7}{*}{$\begin{array}{l}\underline{\text { PMV-Value }} \\
\text { The climBOTs }\end{array}$} & \multirow{7}{*}{$\begin{array}{c}\text { The } \\
\text { Mathematics }\end{array}$} \\
\hline Temperature & $\underline{\text { Water Flux }}$ & temperature & $\underline{\text { Fluxes }}$ & & \\
\hline Vapor & \multirow[t]{5}{*}{ Water Bodies } & Heat exchange & Fluxes at Walls / & & \\
\hline$\underline{\text { Turbulence }}$ & & $\underline{\text { Vapor exchange }}$ & $\underline{\text { Roofs }}$ & & \\
\hline$\underline{\text { Pollutants }}$ & & $\underline{\text { Water }}$ & $\underline{\text { Heat transfer through }}$ & & \\
\hline & & Interception & $\underline{\text { Walls }}$ & & \\
\hline & & $\underline{\text { Water Transport }}$ & & & \\
\hline
\end{tabular}

Fonte: ENVI-met 3.0 Manual. Disponível em. http://envi-met.com. Acesso em agosto de

2007.

Além dos modelos de cálculo para vegetação, o ENVI-met também aborda:

- Cálculo de radiação de onda longa e curta considerando os efeitos de sombreamento, reflexão e re-emissão dos edifícios e vegetação.

- Temperatura de superfície e paredes para cada ponto da grade do modelo.

- Trocas de calor e água dentro do sistema do solo escolhido.

- Dispersão dos gases e partículas poluentes incluindo a sedimentação de partículas nas superfícies e folhas.

O modelo Envi-met permite avaliar o microclima de uma determinada área que sofre influência das condições climáticas tais como radiação solar, orientação dos ventos e umidade do ar. Possibilita também avaliar o comportamento de materiais existentes em edifícios e ruas, analisa a dispersão dos poluentes e determina o fluxo de calor entre os materiais.

Dentre todas as possibilidades oferecidas pelo modelo, esta pesquisa buscou como foco principal o desempenho dos modelos voltados para vegetação e a resposta para diferentes situações no funcionamento interno das plantas.

A Figura 45 mostra uma parte explicativa do programa que apresenta os tipos de análises possíveis pela vegetação: temperatura da folha, troca de calor, troca de vapor e transporte interno de água. 


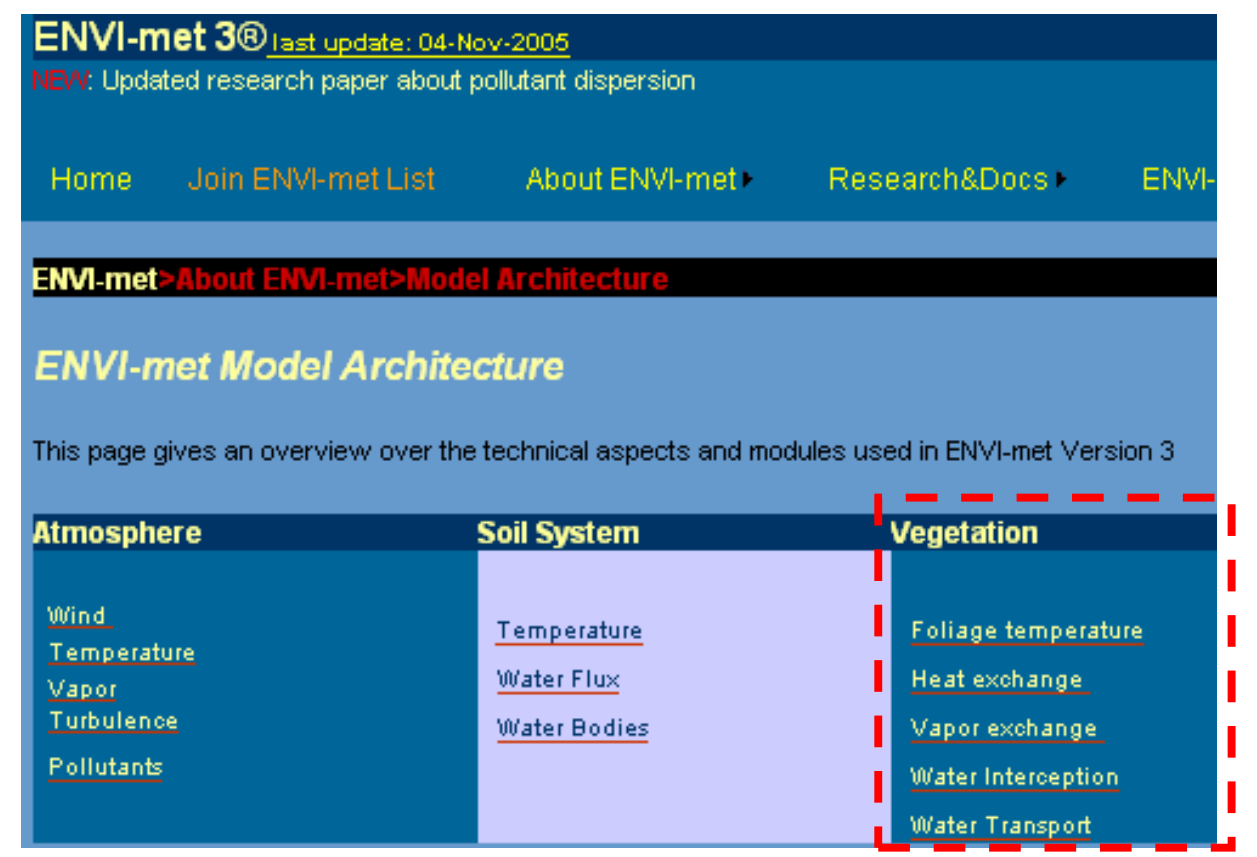

Figura 45: Apresentação das principais ferramentas oferecidas pelo Envi-met para análise da vegetação.

Fonte: ENVI-met 3.0 Manual. Disponível em. http://envi-met.com, acesso em junho de 2007.

Chatzidimitriou et al. (2005) avaliaram o uso do modelo para uma avenida muito movimentada em Thessaloniki, Grécia. A partir da situação existente foram propostas intervenções por meio da inserção de vegetação e áreas sombreadas para passagem de pedestres. As propostas foram sugeridas com base nas simulações feitas pelo modelo ENVI-met e comparadas com as medições locais realizadas no período de verão.

Yu e Hien (2005) aplicaram o modelo ENVI-met para avaliar os benefícios dos parques urbanos na cidade de Cingapura. As medições foram feitas para os parques e outras áreas próximas considerando-se os seguintes parâmetros: temperatura do ar, umidade relativa, velocidade dos ventos, quantidade de chuva e radiação solar. Estes valores foram incorporados no modelo ENVI-met e os resultados mostraram a influência da vegetação no resfriamento da temperatura do ar e a redução do consumo de energia pelo sistema de ar condicionado.

Existem muitos trabalhos que aplicaram o modelo ENVI-met para cidades européias e asiáticas. Por outro lado, existe um potencial a ser explorado quanto ao uso do modelo nos trópicos. Baseando-se nas metodologias já utilizadas, foi feito um estudo do 
programa e foram levantadas formas de aplicação para as condições microclimáticas da cidade de São Paulo.

\subsection{APLICAÇÃO DO MODELO}

O processo de simulação ocorre segundo três fases principais: definição da modelagem, definição dos dados de entrada e escolha dos dados de saída.

\subsubsection{DEFINIÇÃO DA MODELAGEM}

O ENVI-met é um modelo 3D e está organizado de acordo com uma grade (grid) nos eixos x, y e z (Figura 46). O primeiro passo é configurar a dimensão de cada célula da grade, sendo o valor mínimo de $1 \mathrm{~m}$ x $1 \mathrm{~m}$. A altura máxima do modelo é de $2.500 \mathrm{~m}$, permitido uma distribuição de três formas: eqüidistantes (células verticais de tamanho igual), telescópico e telescópico com fator de extensão. Nesta última opção, as células estão distribuídas conforme a equação:

$\Delta \mathbf{z}(\mathbf{k})=[1+(\mathbf{S} / \mathbf{1 0 0})]^{\mathrm{k}-1} \cdot \Delta \mathbf{z}_{\text {start }}$

Onde,

$\mathbf{S}=$ Fator de extensão

$\Delta \mathbf{z}_{\text {start }}=$ tamanho do primeiro grid .

Além dos limites do modelo definido, é possível acrescentar células bidimensionais (eixo $\mathrm{x}, \mathrm{y}$ ) chamadas nesting grids. A função dos nesting grids é criar uma área de transição em volta do modelo para os fluxos de vento e radiação e evitar problemas nos cálculos das bordas do modelo. 


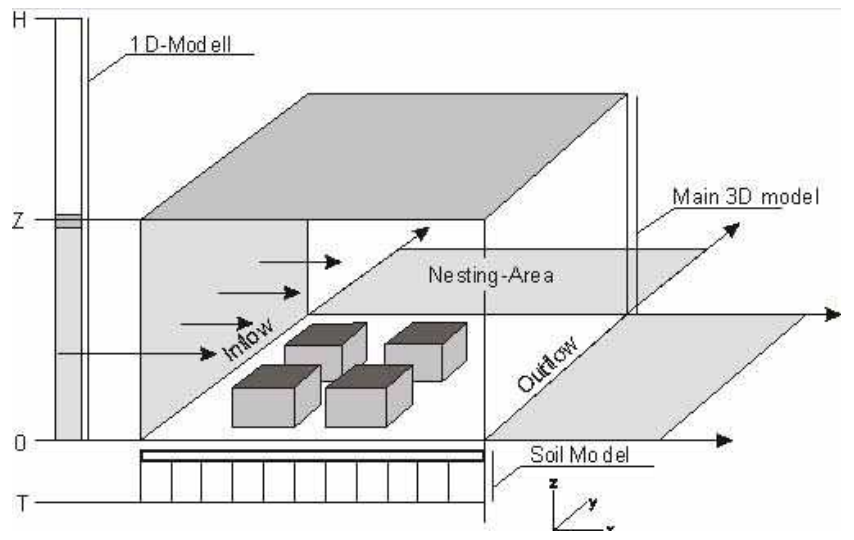

Figura 46: Layout básico do modelo ENVI-met.

Fonte: ENVI-met 3.0 Manual. Disponível em. 〈http://envi-met.com/>. Acesso em agosto de 2007.
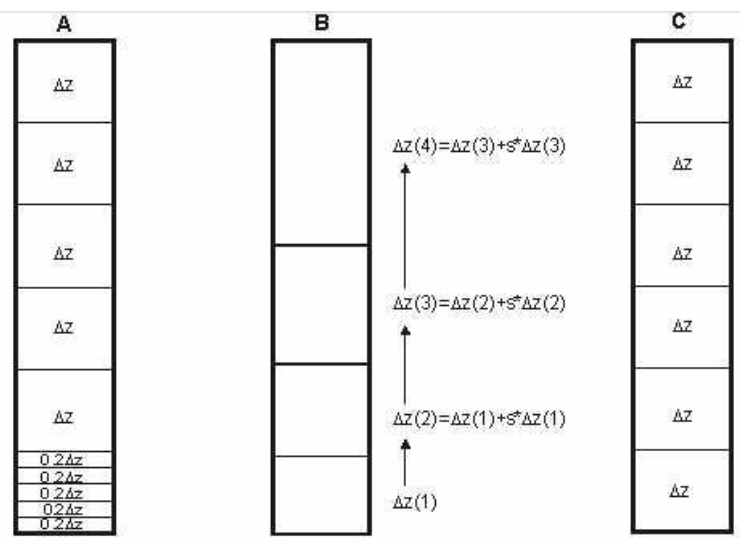

Figura 47: Distribuição das alturas: Eqüidistante (A), Telescópico com fator de extensão (B) e Telescópico (C).

Fonte: ENVI-met 3.0 Manual. Disponível em. http://envi-met.com/. Acesso em agosto de 2007.

Definidos os limites e o tamanho das células do modelo, é possível criar a geometria urbana da área de estudo utilizando-se os bancos de dados de solo, materiais e vegetação. $\mathrm{O}$ banco de dados de solo apresenta vinte tipos de solo com a descrição das principais características: condutividade do material, capacidade térmica, volume de água existente e potencial de saturação. $\mathrm{O}$ banco de dados de materiais tem os seguintes tipos: piso impermeável, asfalto, cimento, solos arenosos, argilosos e corpos d'água. Cada material tem características específicas quanto ao albedo, rugosidade e emissividade da radiação de onda longa. Os cálculos matemáticos dos modelos atmosféricos, solo e vegetação estão descritos com mais detalhes no item 4.3. 




Figura 48: Modelagem 3D no Envi-met

Fonte: Disponível em http://www.geographie.ruhr-uni-bochum.de/agklima/envimet/ .

Acesso em agosto de 2007.

\subsubsection{DEFINIÇÃO DOS DADOS DE ENTRADA - Configuration Editor}

Os principais parâmetros de simulação estão organizados da seguinte forma:

- Dados de simulação: nome do arquivo de entrada e saída; tempo de início e término das simulações, armazenamento dos dados com intervalos determinados.

- Condições ambientais do modelo: temperatura inicial do ar, umidade do ar a $2 \mathrm{~m}$ e 2500m de altura, velocidade e intensidade dos ventos, rugosidade da superfície, posição geográfica (latitude, longitude, zonas), nesting grids, tipo de céu (posicionamento de nuvens) e concentração de partículas poluentes.

- Condições internas do modelo: dados de solo, materiais e plantas; propriedades dos edifícios, emissão de calor antropogênico. A análise mais detalhada do modelo pode ser feita por meio da colocação de receptores que fornecem dados específicos de umidade e temperatura do ar e superfície.

\subsubsection{ESCOLHA DOS DADOS DE SAÍDA}

A dimensão do modelo, baseada no número de grids definidos e no tamanho de cada célula, determina o tipo do formato para se iniciar a simulação. O modelo apresenta seis opções de formato para processar a simulação (Figura 49). Quanto maior a resolução, maior o tempo necessário para se gerar os resultados. 


\begin{tabular}{|l|l|}
\hline $60 \times 60 \times 30$ Grids & 128 Mbytes \\
\hline $80 \times 80 \times 30$ Grids & 128 Mbytes \\
\hline $120 \times 120 \times 30$ Grids & 256 Mbytes \\
\hline $130 \times 130 \times 30$ Grids & 256 Mbytes \\
\hline $200 \times 200 \times 25$ Grids & 512 Mbytes \\
\hline $250 \times 250 \times 25$ Grids & 1 GByte \\
\hline
\end{tabular}

Figura 49: Opções do formato final a ser simulado no modelo ENVI-met.

Fonte: Disponível em http://www.geographie.ruhr-uni-bochum.de/agklima/envimet/ .

Acesso em agosto de 2007.

O ENVI-met oferece mais de quarenta opções de dados de saída, dentre elas: fluxo de ar, intensidade dos ventos, umidade específica, temperatura do ar, radiação direta, radiação difusa, radiação refletida, fator de visão de céu, água nas folhas, valores de PMV, resistência dos estômatos, fluxo de $\mathrm{CO}_{2}$ nas plantas e valor absoluto de $\mathrm{LAD}^{54}$.

Os arquivos do ENVI-met têm formato EDT e EDI, podendo-se exportá-los para as planilhas de cálculo, tais como o Excel. Outra forma de visualização é por meio do modelo Leonardo ${ }^{55}$ no formato 2D e 3D (Figura 50 e 51).
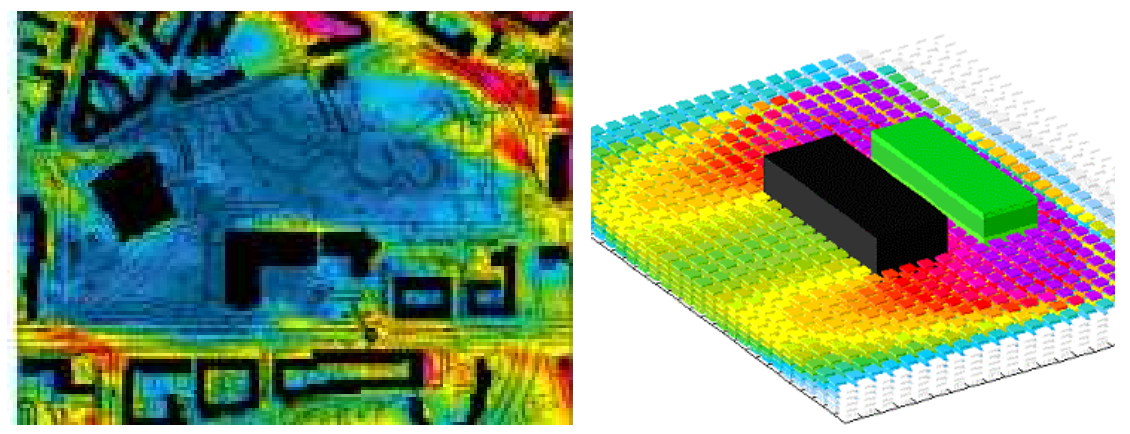

Figura 50: Resultados de simulações geradas pelo Leonardo (2D)

Figura 51: Resultados de simulações geradas pelo Leonardo (3D)

Fonte: Disponível em < http://www.envi-met.com >. Acesso em agosto de 2007.

\footnotetext{
${ }^{54}$ O Índice de Densidade Foliar ou Leaf Area Density - LAD é definido pela relação entre a área total de folhas pelo volume das camadas na copa $\left(\mathrm{m}^{2} / \mathrm{m}^{3}\right)$, segundo Hosoi e Omasa (2006). Esse índice está descrito com mais detalhes no item 5.2: Medições do Índice de Área Foliar - LAI

${ }^{55}$ Disponível em http://www.geographie.ruhr-uni-bochum.de/agklima/envimet/\#walls, acesso em ago de 2007.
} 


\subsection{MODELO DE CÁLCULO DA VEGETAÇÃO NO ENVI-MET}

A influência da vegetação ocorre de duas principais formas: direta, quando se consideram os desvios na direção dos ventos pelas árvores e o sombreamento de áreas laterais adjacentes, e indireta, que ocorre pelo processo de evapotranspiração das plantas.

A influência direta pode ser determinada por cálculos matemáticos, a partir da geometria da árvore e a altura do sol de acordo com os horários do dia ou mesmo por simulações experimentais em túnel de vento para se verificar as mudanças na orientação dos ventos por um certo grupo de árvores.

Por outro lado, os cálculos para se determinar a influência do processo de evapotranspiração envolvem parametrizações complexas que consideram o sistema fisiológico da planta e as condições externas como temperatura, umidade relativa e quantidade de $\mathrm{CO}_{2}$ existente na atmosfera.

O modelo Envi-met apresenta dois modelos de cálculo da transpiração das plantas, sendo um primeiro método baseado no trabalho publicado por J. W. Deardorff em 1978 e um segundo método de cálculo elaborado por C. M. J. Jacobs (1994).

Ambos os estudos têm como base de cálculo a resistência dos estômatos; porém, a principal diferença entre os dois métodos está nas condicionantes que cada um utilizou, sendo que nas equações de Deardorff os valores máximos estimados dependem da radiação solar e da quantidade de água, enquanto Jacobs considera o controle dos estômatos e a quantidade de $\mathrm{CO}_{2}$.

Outro fator que influencia os cálculos do ENVI-met é o tipo da vegetação escolhida. Todas as informações de cada espécie estão contidas no arquivo PLANTS. DAT, banco de dados de vegetação com doze tipos de espécies.

A Figura 52 apresenta um quadro de configuração para a escolha do método de cálculo a ser utilizado na simulação; o próprio Envi-met sugere o uso do modelo A-gs de Jacobs (em default) ao invés dos estudos de Deardorff, pelo fato de Jacobs adaptar-se melhor aos conceitos fisiológicos das plantas. 
Em seguida, o programa permite alterar a concentração de $\mathrm{CO}_{2}$ na atmosfera ou manter o valor médio de $350 \mathrm{ppm}$, lembrando que esta quantidade apenas influencia nos resultados do modelo A-gs.

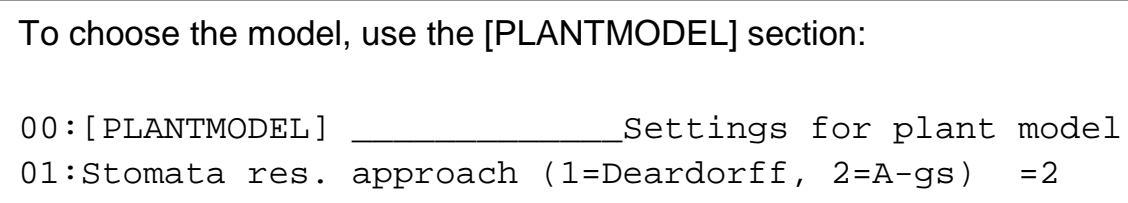

Figura 52: Quadro de Configuração do Modelo de Cálculo da Vegetação.

Fonte: Configurações do ENVI-met. Disponível em: < http://envi-met.com/>. Acesso em agosto de 2007.

Os modelos de cálculo também possibilitam determinar o fluxo de calor entre a planta e o meio externo, a partir de uma única folha até uma simulação mais ampla que inclua o fator de sombreamento, absorção, reflexão para o ambiente e para outras partes da planta.

O balanço de energia é definido pelas trocas de calor, dada a temperatura superficial da folha e o controle da entrada e saída de gases, principalmente $\mathrm{CO}_{2}$. Desta forma, a taxa de fotossíntese é determinante para o equilíbrio final do balanço energético da planta, pois depende da entrada e saída de gases (vapor, $\mathrm{CO}_{2}$ e $\mathrm{O}_{2}$ ) e energia (radiação solar).

O processo de fotossíntese também necessita da presença de água para ocorrer, ao mesmo tempo em que, de acordo com a temperatura externa, haverá uma maior perda de água pela evaporação na superfície das folhas.

Assim, todo o transporte, o armazenamento e a absorção da água da chuva serão considerados pelo ENVI-met como um modelo independente dentro dos métodos de cálculo.

As equações de cada modelo matemático estão descritas com maior detalhe nos itens a seguir, comparando-se os principais conceitos de cada método matemático adotado pelo programa. 


\subsubsection{O MODELO DE DEARDORFF}

Ainda se sabe muito pouco sobre o comportamento dos estômatos (Mott, 1990; Wolfe, 1994).

Conforme explicado anteriormente, o controle de abertura está diretamente relacionado com os fatores que possibilitam o processo de fotossíntese como, por exemplo, a quantidade de água, a radiação solar e o $\mathrm{CO}_{2}$.

Os estudos de Deardorff são extremamente importantes para se compreender quais são as variáveis que influenciam no comportamento da folha, tais como a temperatura superficial, o fluxo de calor sensível e a taxa de evapotranspiração, além de identificar correlações gerais entre as variáveis por meio de equações matemáticas e coeficientes estimados com base nas observações experimentais dos estudos.

A equação que define o cálculo para a resistência dos estômatos é:

$R s=2\left[S_{\max } /\left(S+0.03 S_{\max }\right)+S+\left(W_{\text {wilt }} / W_{S}\right)^{2}\right]$

Onde:

Rs $=$ resistência dos estômatos

$\mathbf{S}_{\mathbf{m a x}}=$ máximo ganho de radiação solar ao meio dia.

$\mathbf{S}=$ valor de radiação solar

$\mathbf{W}_{\text {wilt }}=$ valor da pior condição de umidade do solo, quando comparado ao valor de saturação máxima.

$\mathbf{W}_{\mathrm{s}}=$ valor de umidade do solo na zona de onde se encontram as raízes.

No cálculo da resistência dos estômatos, o valor da radiação solar como variável na equação foi sugerida por Cline e Campbell (1976), Waggoner e Reifsnyder (1968) e Monteith et al. (1965).

Numa segunda abordagem, Deardorff considera a geometria da planta, relacionando a temperatura embaixo da copa da árvore com a temperatura no topo da árvore, e a densidade das folhas que impedem a chegada da radiação de onda curta no solo. 
Como resultado, tem-se que:

$C_{H g}=\left(1-\sigma_{f}\right) C_{H 0}+\sigma_{f} C_{H h}$

Onde:

$\mathbf{C}_{\mathbf{H g}}=$ coeficiente de transferência de calor e umidade na superfície do solo, logo abaixo da copa da árvore.

$\mathbf{C}_{\mathbf{H} \mathbf{0}}=$ coeficiente de transferência de calor e umidade na superfície do solo não coberta pela copa da árvore.

$\mathbf{C}_{\mathbf{H h}}=$ coeficiente de transferência de calor e umidade na superfície do topo da copa da árvore.

$\sigma_{\mathrm{f}}=$ coeficiente de densidade da copa da árvore, sendo que os limites são:

$0<\sigma_{\mathrm{f}}<1 ;$ ( 0 significando árvores sem folhagem e 1 para copas muito densas $)$.

\subsubsection{O MODELO DE JACOBS}

A base do modelo de Jacobs é o processo fisiológico das plantas. De acordo com a descrição dos cálculos utilizados no modelo Envi-met, Bruse (2006) acredita que o modelo mais adequado para demonstrar o real comportamento das folhas é aquele que considera a concentração de $\mathrm{CO}_{2}$ e os efeitos causados por partículas poluentes.

Uma das principais desvantagens do modelo de Deardorff está no tratamento independente das variáveis que não permitem uma dinâmica adaptação a novas situações, ao mesmo tempo em que se baseia em valores estatísticos provenientes dos trabalhos experimentais.

Em geral, a maioria dos modelos considera a planta como uma única grande folha exposta às condições de um microclima estável, e obtém valores médios em seus resultados finais. Assim, estes resultados pouco esclarecem sobre as mudanças microclimáticas em determinados momentos do dia e o real comportamento das folhas a partir de diversas condicionantes como radiação, ventilação, quantidade de água, $\mathrm{CO}_{2}$, índice de sombreamento, etc. 
Neste sentido, o modelo ENVI-met sugere o sistema de cálculo de Jacobs (1994), chamado A-gs, a fim de se obter resultados mais precisos nas simulações.

Considerando-se que os processos de transpiração e fotossíntese utilizam o mesmo caminho para transportar vapor de água e dióxido de carbono até os estômatos, fica claro que a descrição fisiológica da condução de água e nutrientes pelo corpo das plantas possibilita modelos e resultados conceitualmente mais próximos da situação real (Bruse, 2004).

Jacobs indica uma diferença na terminologia em que os fisiologistas utilizam mais o termo "condução" (conductance) ao invés de "resitência" (resistance). Nos seus trabalhos, os dois termos foram colocados para diferenciar a escala de estudo; quando se trata da folha, é utilizado o termo condução (condução dos estômatos) e, para a copa, o termo resistência (resistência da superfície).

Proposto por Jacobs, o Modelos Ag-s é a junção de dois modelos: um para a condução dos estômatos $\left(\mathrm{g}_{\mathrm{s}}\right)$ e outro para a taxa do processo de fotossíntese $\left(\mathrm{A}_{\mathrm{n}}\right)$. Este modelo faz uma parametrização da resposta dos estômatos em relação à umidade e como isso afeta a concentração do $\mathrm{CO}_{2}(\mathrm{Ci})$ interno e $\mathrm{CO}_{2}$ externo $(\mathrm{Cs})$.

Este modelo pode ser descrito da seguinte forma:

$$
\mathrm{g}_{\mathrm{s}}=1.6 \text { An }
$$

$$
\mathbf{C}_{\mathrm{s}} \mathbf{C}_{\mathrm{i}}
$$

Onde:

$\mathbf{g}_{\mathrm{s}}=$ condução dos estômatos

$\mathbf{A}_{\mathbf{n}}=$ taxa de fotossíntese

$\mathbf{C}_{\mathbf{s}}=$ concentração de $\mathrm{CO}_{2}$ na superfície da folha

$\mathbf{C}_{\mathbf{i}}=$ concentração de $\mathrm{CO}_{2}$ dentro da folha 
A condução dos estômatos $\left(\mathrm{g}_{\mathrm{s}}\right)$, que considera a interação entre as trocas de $\mathrm{CO}_{2}$ e $\mathrm{H}_{2} \mathrm{O}$, está em $\left[\mathrm{mms}^{-1}\right]$. Assim, para se converter em resistência dos estômatos, deve-se realizar o seguinte cálculo:

$$
\text { Rs }=1 / g_{s} \times 1000
$$

O modelo JS por Javis (1979) e Stewart (1988) usado em pesquisas micrometeorológicas, modelos de mesoescala e modelos climáticos, ajudou como base para desenvolver o Modelo Ag-s, pois indicava os fatores para controle do comportamento dos estômatos durante um determinado período de tempo (Jacobs, 1994).

Segundo seus estudos, os principais problemas apresentados pelo modelo JS são:

- Considera pequenos valores para concentração de $\mathrm{CO}_{2}$ na atmosfera, prejudicando os resultados e as relações entre os fatores internos da planta.

- A maior parte dos resultados é gerada para o período noturno, quando os estômatos estão, em geral, fechados.

- Não consideram a relação entre $\mathrm{CO}_{2}$ e o comportamento dos estômatos.

\subsection{LIMITAÇÕES DO MODELO ENVI-MET}

Segundo Johansson (2006), as principais limitações do modelo são:

- Não considera massa térmica na fachada dos edifícios, sendo a capacidade térmica apenas presente no solo. Este fato subestima o efeito do fluxo da radiação de onda longa, uma vez que não existe o acúmulo de calor pelas fachadas das construções.

- Outra questão é a temperatura interna dos edifícios que se mantém constante durante todo o período de simulação. Esta limitação do programa afeta diretamente os resultados da temperatura de superfície das fachadas e indiretamente a temperatura média radiante e temperatura do ar.

- Os desenhos das áreas urbanas no ENVI-met devem seguir o formato da grade ortogonal. Assim o formato das quadras e ruas precisa ser adaptado, sem considerar as curvas e linhas com inclinações diferenciadas. 


\section{MEDIÇÕES DE CAMPO}

\subsection{MEDIÇÕES MICROCLIMÁTICAS NA ÁREA DA LUZ}

As medições de variáveis climáticas na região da Luz foram feitas pelo grupo de pesquisa do LABAUT - Laboratório de Conforto Ambiental e Eficiência Energética da Faculdade de Arquitetura da Universidade de São Paulo para subsidiar diferentes pesquisas do grupo em andamento (impacto da vegetação em microclimas urbanos, efeito da temperatura superficial nos pavimentos, sensação de conforto térmico dos usuários, etc). O objetivo geral dessas medições era gerar uma base de dados de temperatura do ar, umidade do ar, radiação e intensidade dos ventos para poder avaliar como as condições climáticas variam de acordo com diferentes situações urbanas. Para esta pesquisa em especial, foram realizadas medições microclimáticas nas áreas de estudo, no nível do pedestre, nos períodos de dezembro de 2006 e abril de 2007, para alimentar as simulações computacionais no ENVI-met. Para esta etapa contou-se com o apoio da equipe do LABAUT, que já tem experiência em trabalhos de campo similares (SOUZA, DUARTE, 2004; PRATA, 2005; DUARTE, GONÇALVES, 2006), e dos equipamentos existentes no laboratório, parte deles adquiridos com recursos da FAPESP (1995/5597-5) e o processo de doutorado da Alessandra Prata FAPESP (02/07513-9).

\subsubsection{ESCOLHA DOS PONTOS}

A escolha dos pontos na área da Luz ocorreu em função de diversidade de situações urbanas que podem ser exploradas quanto às condições climáticas. No Atlas Ambiental de São Paulo (SVMA, 2000), observa-se a diferença de temperatura superficial existente na cidade de São Paulo. A figura 53 mostra a área do Parque da Luz com temperaturas superficiais mais reduzidas do que em outras regiões centrais como Pari, Brás e Belém. Esse efeito se repete tanto para o Parque da Água Branca, na região da Barra Funda, zona oeste de São Paulo, como para o Parque Trianon, na Av. Paulista. Estes resultados representam as condições para as 9h57 do dia 03/ 09/ 1999. 


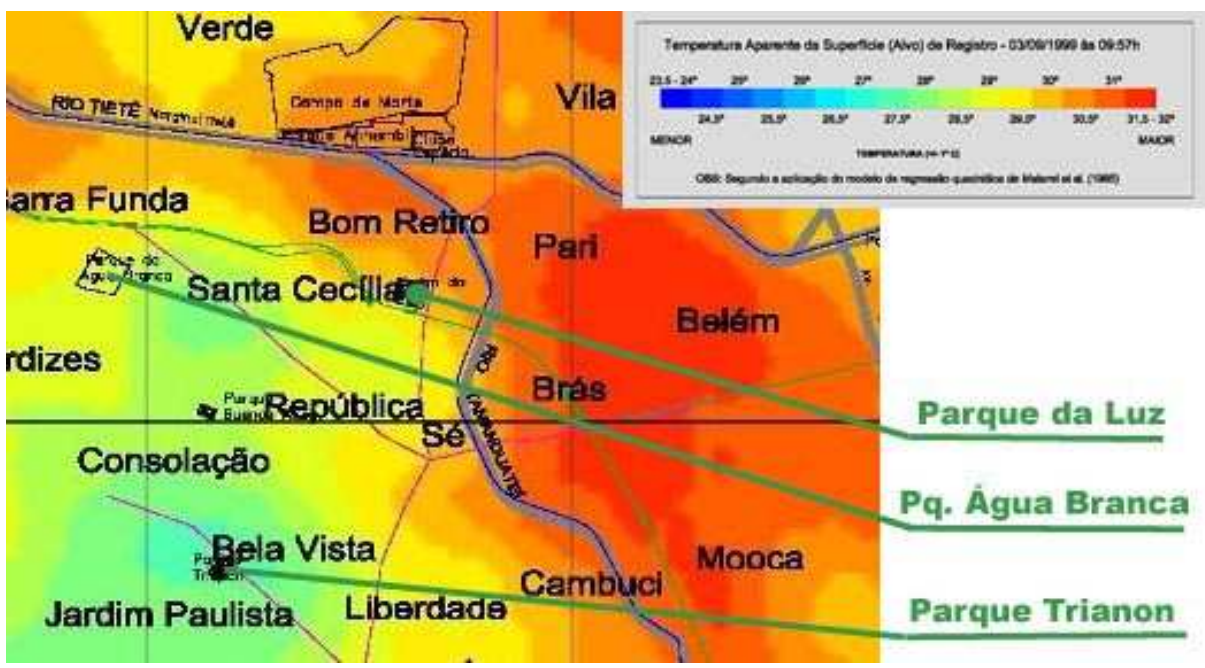

Figura 53: Imagem do mapa de Temperatura Aparente da Superfície - 03/09/1999 às 9:57 - com indicação dos principais parques na região central.

Fonte: Atlas Ambiental da SVMA - 2000.

A primeira etapa de medição foi realizada no dia 19 de dezembro de 2006 . A fim de se verificar com mais detalhes a influência da vegetação no microclima da área da Luz, escolheu-se o Parque que funciona como um oásis na parte central da cidade para verificar qual a sua real contribuição para a redução da temperatura no período de verão.

Contrário a este quadro buscou-se uma outra área sem arborização nas calçadas e com características de canyon, mais adensada e com prédios altos. Assim definiu-se um segundo ponto de medição na Rua dos Andradas, com grande fluxo de veículos e pedestres interessados no comércio local. Em parte, este fluxo é causado pela proximidade com a Rua Santa Efigênia, caracterizada pelo comércio de eletrônicos.

E como terceira opção, foi interessante verificar uma área intermediária entre as duas situações anteriores. Estabeleceu-se a área da Praça da Luz, em frente à Sala São Paulo, que apresenta um grande movimento principalmente de pedestres que saem do metrô, sendo a área mais exposta à radiação solar direta e aos ventos, uma vez que não tem obstáculos, sejam árvores ou edifícios. Esta praça tem áreas de passagem impermeáveis para a travessia dos pedestres e também alguma área permeável com árvores mais esparsas e pouco densas. 
A expectativa nos resultados das medições estava em se verificar as diferenças entre áreas vegetadas, pouco vegetadas e canyons, $e$ como estas condições urbanas afetam o microclima local.

Algumas restrições foram estabelecidas a fim de garantir a segurança dos equipamentos e do grupo. Verificou-se a presença de seguranças no caso do parque, postos da polícia para a praça e estacionamentos para evitar expor os equipamentos de medição e os computadores na área do canyon. Mesmo com um grande interesse em continuar as medições no período da noite, isso não foi possível devido à falta de segurança no local.

A figura 54 mostra os três pontos fixos de medição: Ponto 1, localizado dentro do Parque da Luz, próximo à Pinacoteca; Ponto 2, na Praça da Luz em frente à Sala São Paulo e o Ponto 3, na rua dos Andradas.

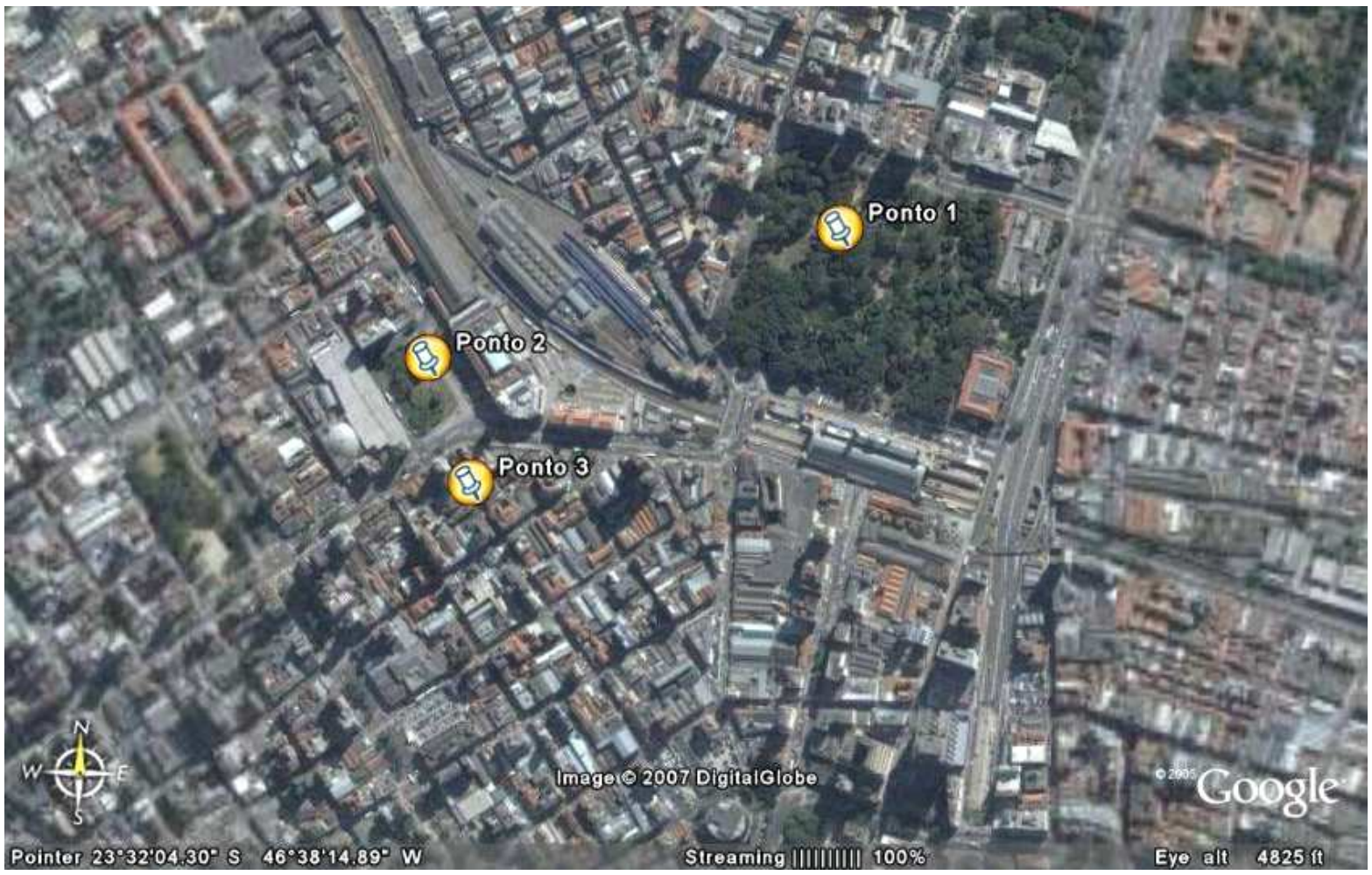

Figura 54: Localização dos três pontos de medição na área da Luz na primeira etapa.

Fonte: Google Earth. Acesso em maio de 2007.

A segunda etapa de medição foi realizada no mês de maio de 2007, e teve como objetivo verificar os efeitos da vegetação do Parque da Luz no seu entorno próximo. Para isso, estabeleceram-se três pontos fixos de medição: Ponto 1, localizado dentro do 
Parque da Luz, próximo ao coreto principal; Ponto 2, também dentro do Parque da Luz, porém próximo ao portão em frente à Estação da Luz e o Ponto 3, na calçada da Estação da Luz, próximo ao Parque. Além desses três pontos foi realizado um transecto na Avenida Casper Líbero que passou por 3 pontos, tendo início na Rua Mauá e fim próximo à Rua Washington Luís ( Figura 55).

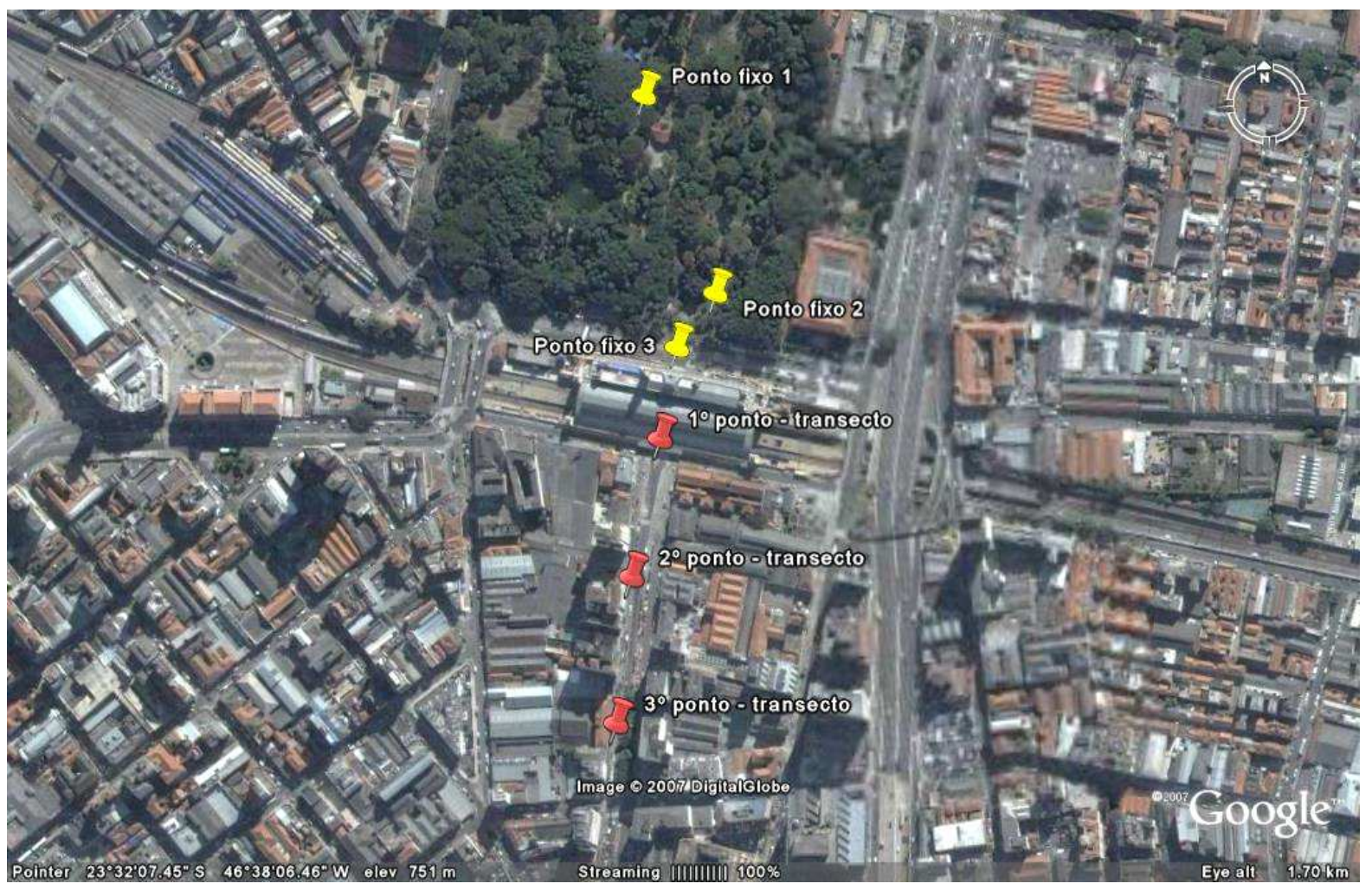

Figura 55: Localização do pontos fixos e do transecto na área da Luz na segunda medição. Fonte: Google Earth. Acesso em julho de 2007.

\subsubsection{EQUIPAMENTOS}

Os equipamentos utilizados nas medidas de campo pertencem ao Laboratório de Conforto e Eficiência Energética LABAUT-FAUUSP e tiveram a seguinte distribuição:

\section{Primeira Medição:}

- Ponto 1 - Estação Meteorológica Huger WM 918 com comunicação direta para o laptop. Os instrumentos deste ponto foram complementados por um termômetro de globo, uma bússola e um sensor HOBO Onset, com canais para temperatura do ar, umidade e iluminância. 

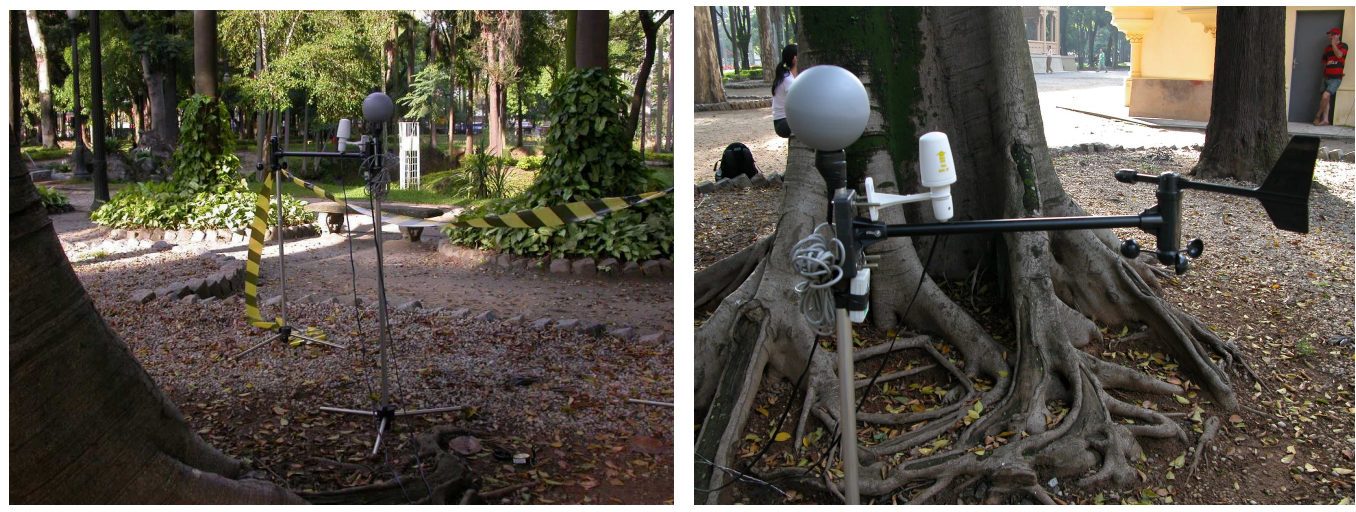

Figura 56: Localização e posicionamento do equipamento no Parque da Luz (fotos: D. Duarte e L. Monteiro)
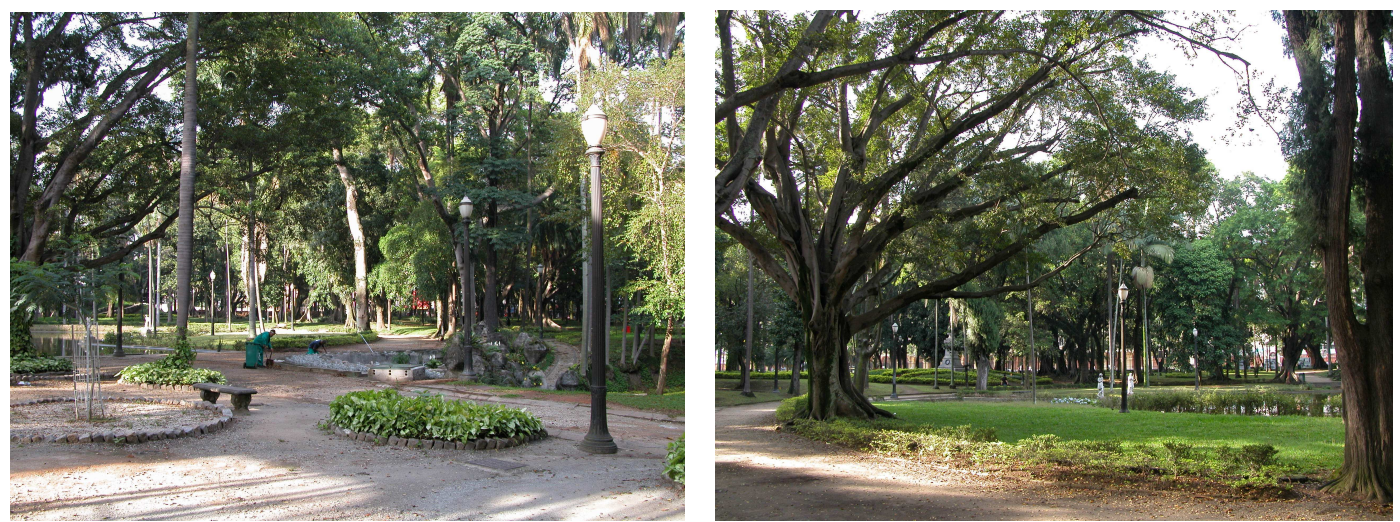

Figura 57: Entorno da área do ponto 1 (fotos: D. Duarte e L. Monteiro).

- Ponto 2 - Estação Meteorológica ELE MM900, adquirida com recursos do processo FAPESP 1995/5597-5, com sensores de temperatura e umidade do ar, direção e velocidade dos ventos e radiação. Também foram utilizados um termômetro de globo e um sensor HOBO Onset, com canais para temperatura do ar, umidade e iluminância.
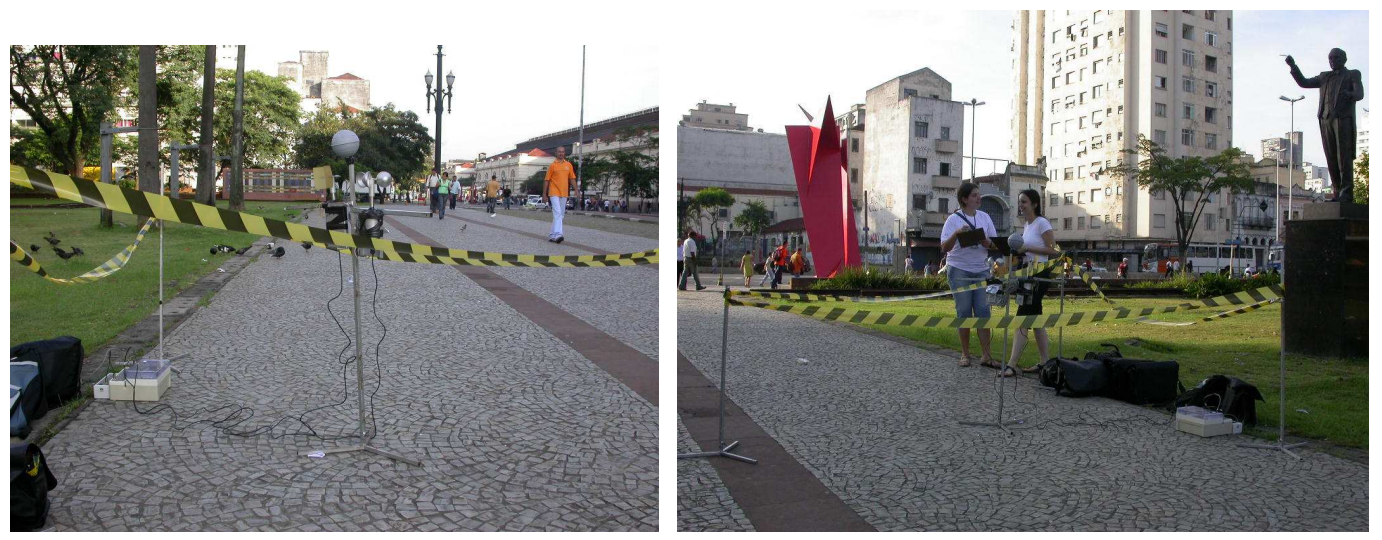

Figura 58: Localização e posicionamento do equipamento na praça (fotos: L. Monteiro). 

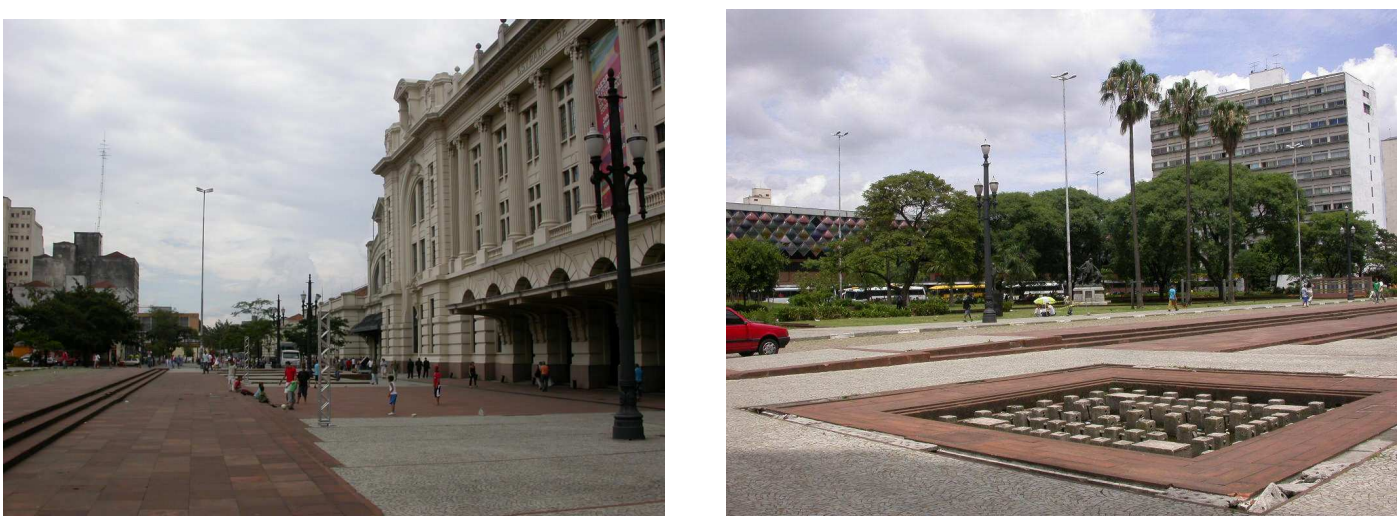

Figura 59: Entorno da área do ponto 2 Estação da Luz e Shopping Luz (fotos: L.

Monteiro).

- Ponto 3 - Estação Meteorológica Oregon Scientific WM 968 com comunicação via freqüência de rádio com laptop, adquirida com recursos do processo FAPESP 02/07513-9. Utilizaram-se também dois sensores HOBO Onset.


Figura 60: Localização e posicionamento do equipamento no canyon (fotos: L. Monteiro).
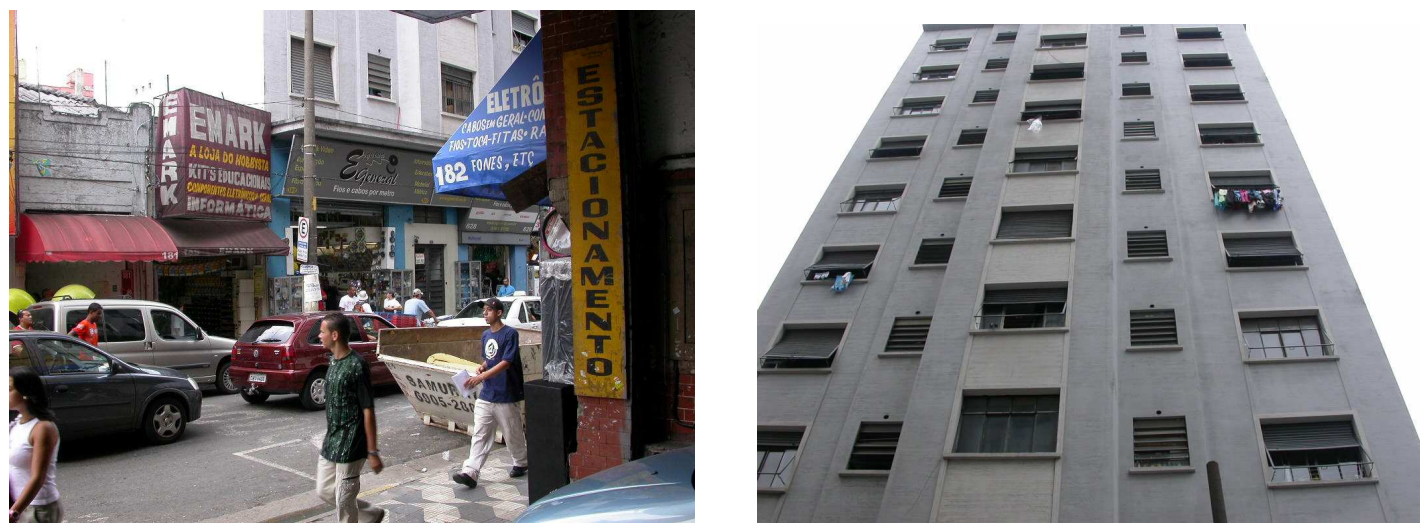

Figura 61: Entorno da área do ponto 3 estabelecimentos comerciais e edifícios altos residenciais (fotos: L. Monteiro). 
Ao longo dos dias de medição foram tiradas fotos de fator de visão de céu para cada ponto de medição com a máquina fotográfica digital Nikon COOLPIX 4500 com lente grande angular (olho-de-peixe) acoplada.

A figura 62 mostra as diferentes visões do céu dos três pontos da primeira medição. As duas primeiras fotos têm o fator de visão de céu reduzido. Na primeira, essa redução é causada pela copa das árvores do Parque; na segunda, pelos edifícios altos do entorno. Apenas na última situação, da praça, tem-se uma ampla visão de céu e pouca obstrução pelos edifícios.
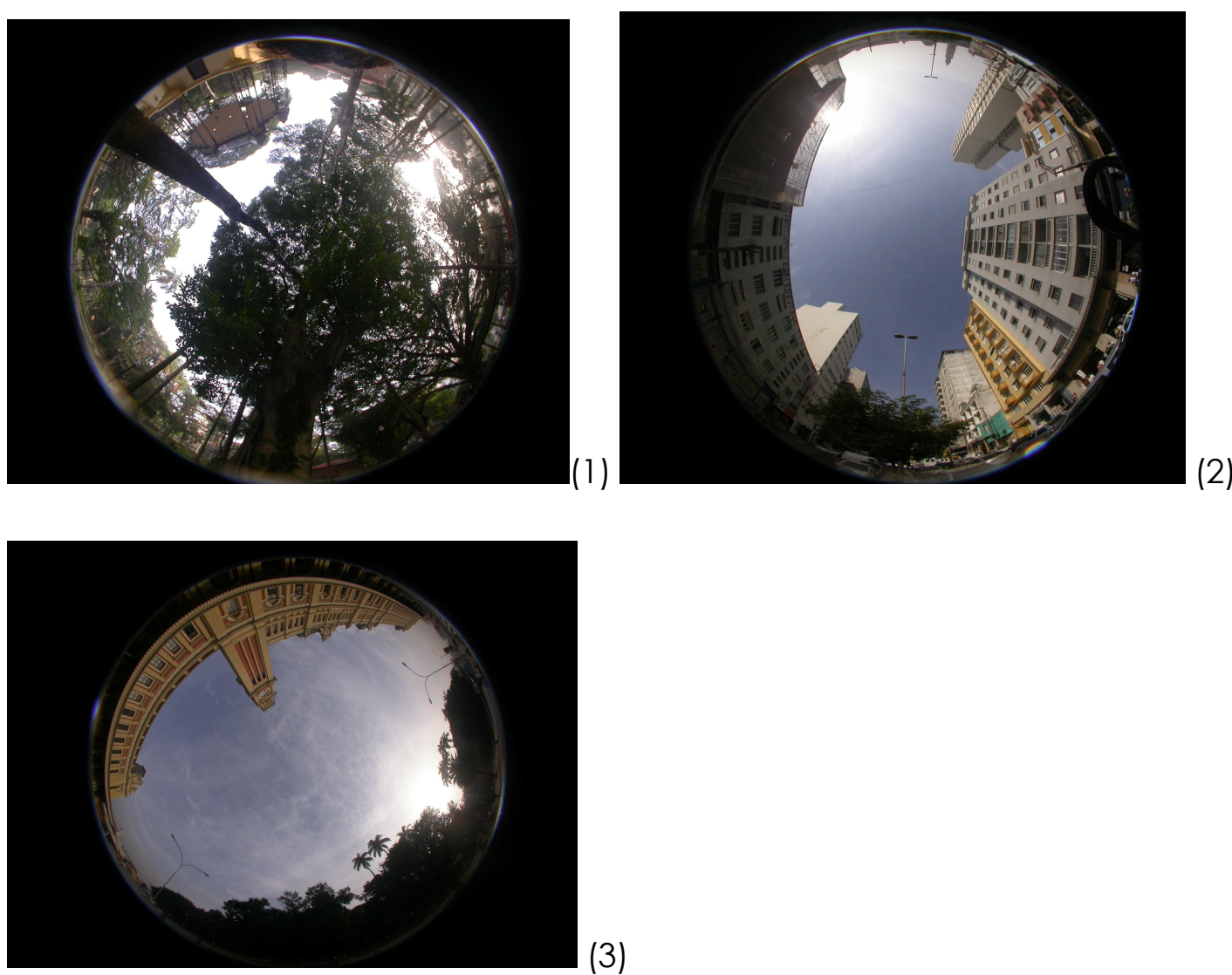

(3)

Figura 62: Foto grande angular do parque da luz (1); foto grande angular da praça (2); foto grande angular do canyon (3) - primeira etapa (fotos: L. Monteiro).

\section{Segunda Medição:}

Os kits de equipamentos montados para a segunda medição foram os mesmos da primeira etapa, porém foram definidos novos pontos, com o objetivo de explorar as diferenças de temperatura do ar e superfície dentro do parque e suas proximidades, ficando da seguinte maneira: 
- Ponto 1 - Estação Meteorológica Huger WM 918 com comunicação direta para o laptop, termômetro de globo, bússola e um sensor HOBO Onset, com canais para temperatura do ar, umidade e iluminância.

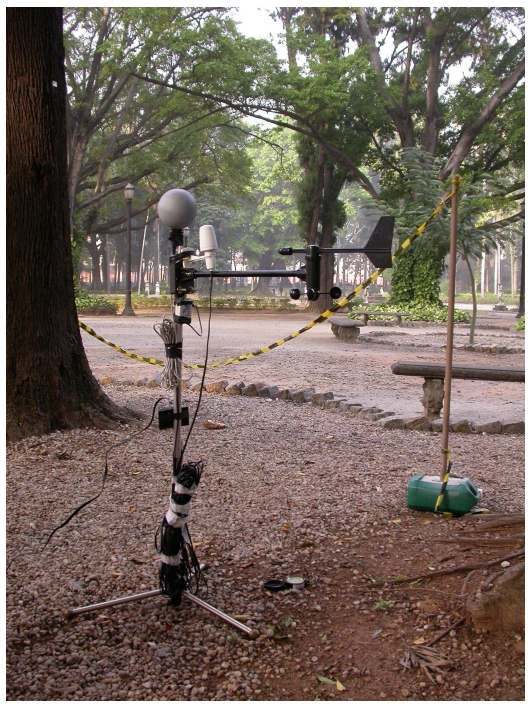

Figura 63: Localização e posicionamento do equipamento no parque P1 (fotos: L. Monteiro).

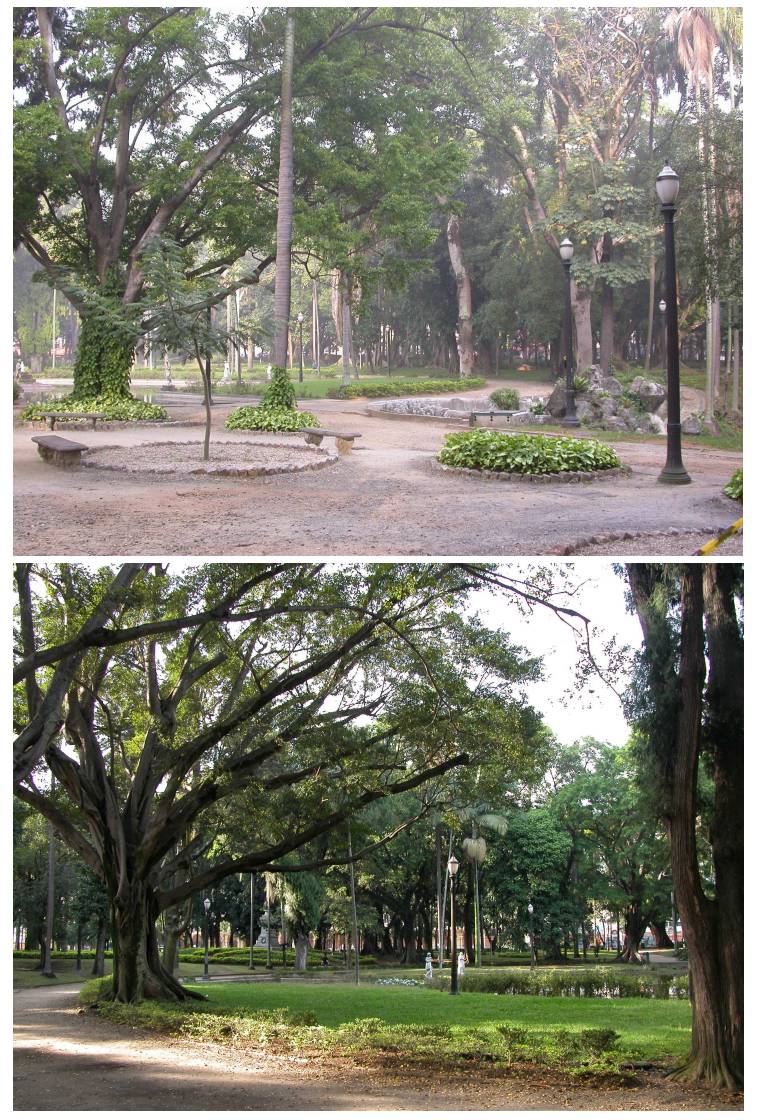

Figura 64: Entorno da área do ponto 1 (fotos: D. Duarte e L. Monteiro). 
- Ponto 2 - Estação Meteorológica Oregon Scientific WM 968 com comunicação via freqüência de rádio com laptop, sensores HOBO Onset e o termômetro de globo.

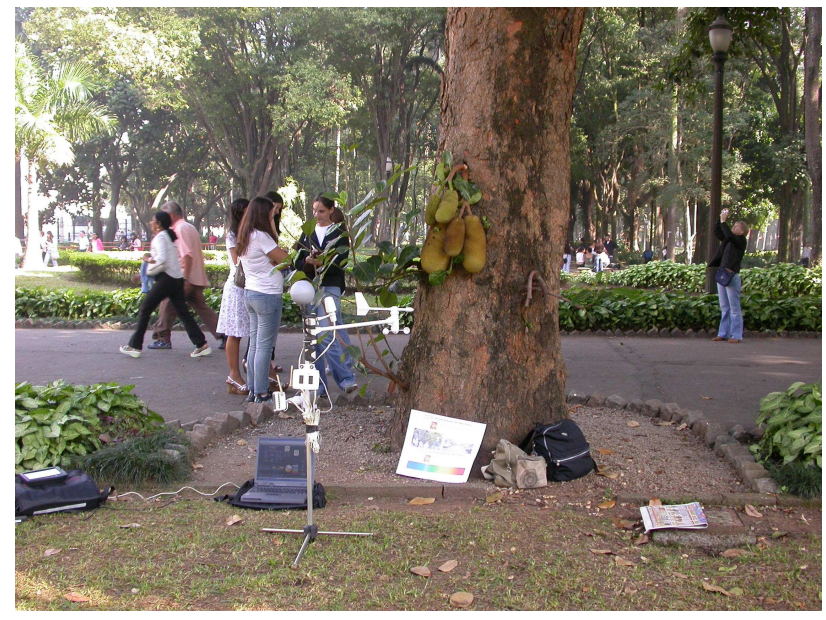

Figura 65: Localização e posicionamento do equipamento no parque P2 (fotos: L. Monteiro).
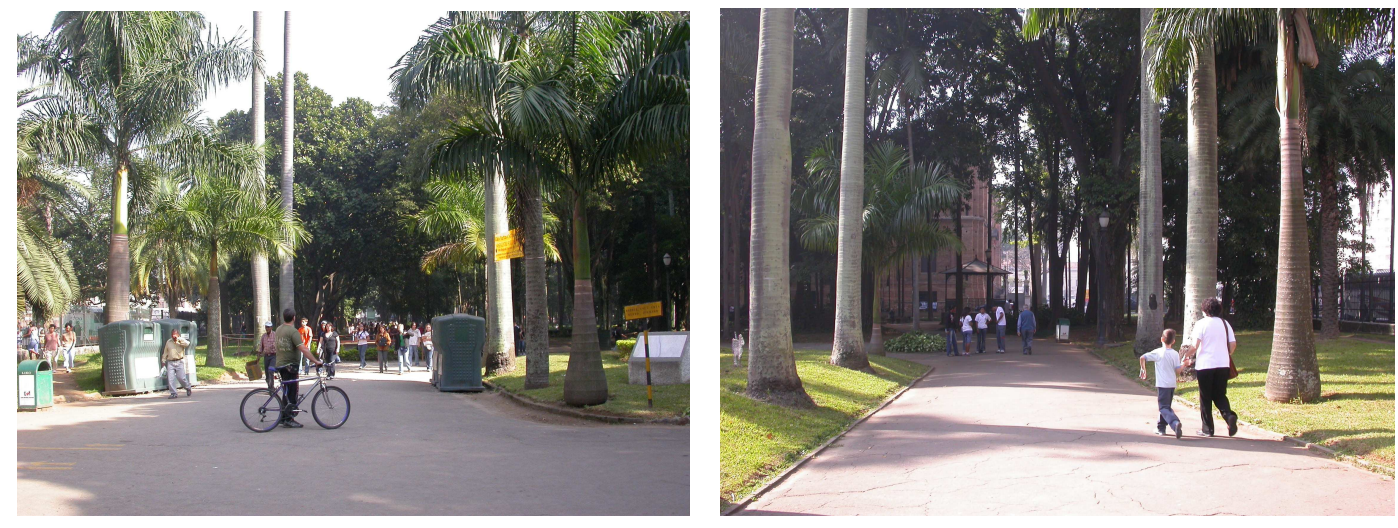

Figura 66: Entorno da área do ponto 2 (fotos: L. Monteiro).

- Ponto 3 - Estação Meteorológica ELE MM900, com sensores de temperatura e umidade do ar, direção e velocidade dos ventos, radiação, um termômetro de globo e um sensor HOBO Onset, com canais para temperatura do ar, umidade e iluminância. 




Figura 67: Localização e posicionamento do equipamento na calçada da Estação da Luz P3 (fotos: L. Monteiro).
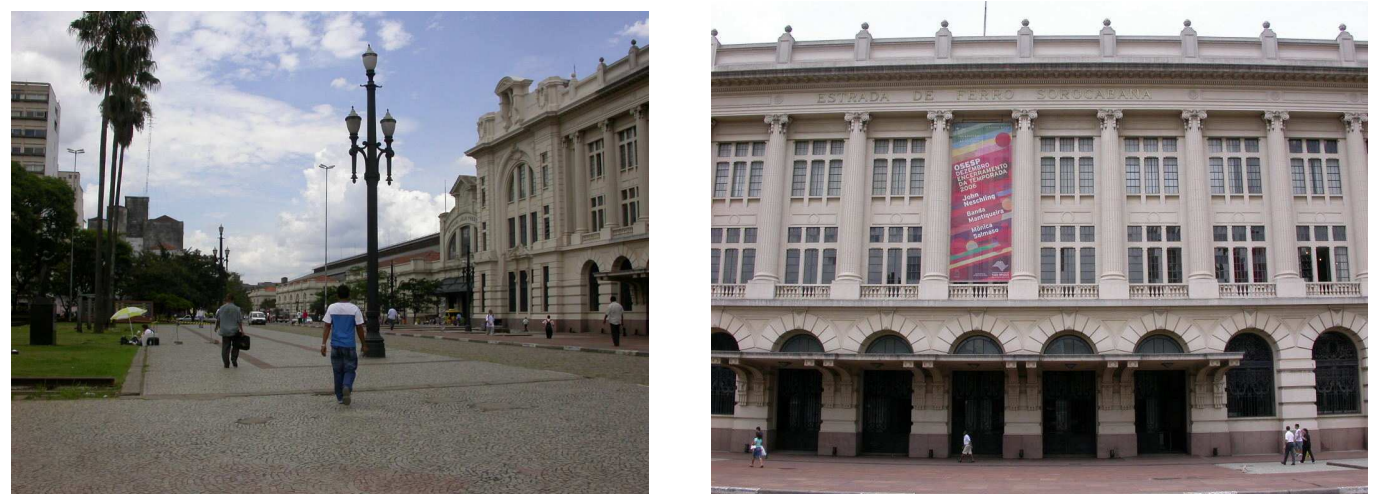

Figura 68: Localização e posicionamento do equipamento na calçada da Estação da Luz P3 (fotos: L. Monteiro).

Além disso, o transecto foi realizado com um sensor HOBO Onset para os dados de temperatura e umidade ao longo da Avenida Casper Líbero (Figura 69).

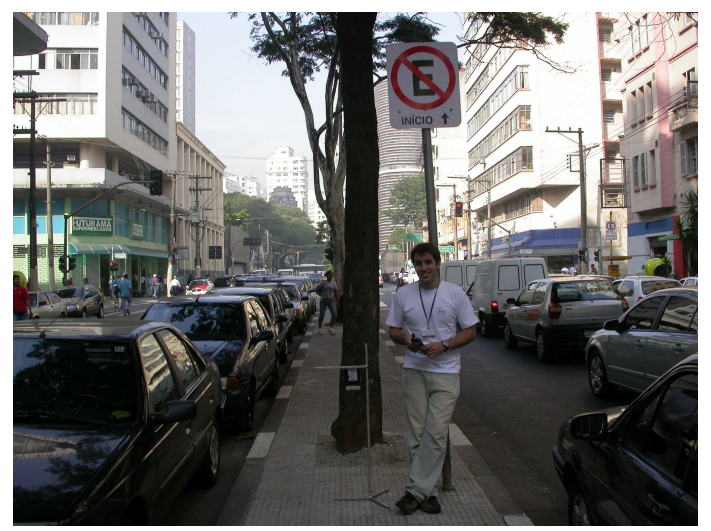

Figura 69: Localização e posicionamento do equipamento no transecto na Avenida Casper Líbero (fotos: L. Monteiro). 
Na segunda medição foram tiradas fotos de fator de visão de céu para cada ponto de medição com a máquina fotográfica digital Nikon COOLPIX 4500 com lente grande angular (olho-de-peixe) acoplada.

A figura 70 mostra as diferentes visões do céu dos três pontos escolhidos para a medição. As duas primeiras fotos têm o fator de visão de céu reduzido pela copa das árvores do Parque; na última situação, pela cobertura da Estação da Luz.
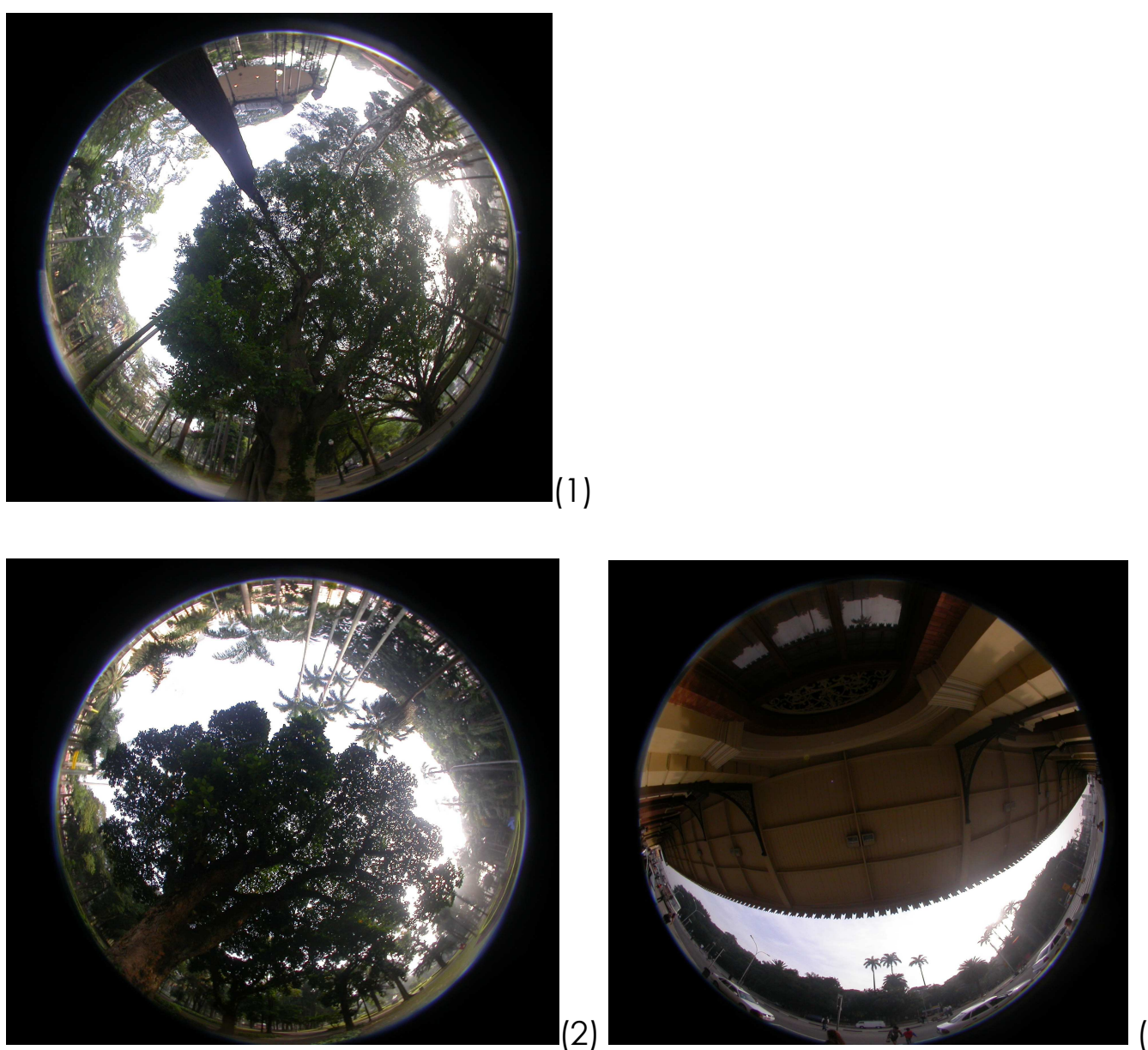

(3)

Figura 70: Foto grande angular do parque da luz (1); foto grande angular no portão do parque (2); foto grande angular da Estação da Luz (3) (fotos: L. Monteiro).

\subsubsection{PROCESSO DE MEDIÇÃO}

Em ambas as medições, os equipamentos foram instalados às $6 \mathrm{~h} 30$ em cada ponto, tomando-se os cuidados com o posicionamento da haste da ventoinha voltado para norte, marcado pela bússola, e corrigindo-se cerca de $18^{\circ}$ à direita, em direção ao norte 
verdadeiro, para a cidade de São Paulo. As medições foram realizadas para os seguintes horários: $7 \mathrm{~h}, 10 \mathrm{~h}, 13 \mathrm{~h}, 16 \mathrm{~h}, 19 \mathrm{~h}$, durante o período de uma hora cada, sendo o registro das medidas feito a cada 10 segundos.

Na segunda etapa de medição o trabalho teve que ser interrompido às $17 \mathrm{~h}$ devido à falta de segurança na região. Os registros brutos dos dados foram armazenados em arquivos separados ao final de cada horário, e a tabulação dos dados foi feita no programa Excel, após as medições.

É importante considerar que, até mesmo por questões de segurança, cada ponto contou com três pessoas para organizar os equipamentos e fazer todos os registros necessários, além de mais duas pessoas de apoio, num total de 11 participantes sob a coordenação das professoras Denise Duarte, Joana Carla Soares Gonçalves e Márcia Peinado Alucci.

Os preparativos para os dias de medição foram feitas em reuniões prévias para se definir o propósito e o método a ser utilizado para as medições, os grupos de pesquisa envolvidos e os possíveis locais de medição e de apoio na região da Luz. Os equipamentos foram montados e testados previamente em laboratório. Finalmente, no máximo dois dias antes de cada etapa montaram-se os kits de cada grupo, checando-se o funcionamento dos instrumentos, as baterias, os programas nos computadores portáteis e a programação dos HOBO Onset.

Na última semana, foram confirmadas as autorizações com os responsáveis pelo Parque da Luz ${ }^{56}$ e pela Sala São Paulo ${ }^{57}$ para entrada dos carros e instalação dos equipamentos.

Os dados obtidos em cada etapa de medição foram tabulados e, a partir destes, gerados gráficos para cada uma das variáveis climáticas: temperatura do ar, umidade relativa do ar, intensidade dos ventos e direção dos ventos.

\subsubsection{ANÁLISE DOS RESULTADOS}

Por meio dos gráficos apresentados, observam-se os seguintes resultados:

\footnotetext{
${ }^{56}$ Edna Ribeiro - Assessora de Imprensa da SVMA - ecribeiro@prefeitura.sp.gov.br

${ }^{57}$ Arquiteto Reinaldo responsável na Sala São Paulo.- reinaldo@osesp.art.br
} 


\section{Primeira etapa de medição}

- As temperaturas iniciais, às $7 \mathrm{~h}^{58}$, foram praticamente iguais nos três pontos de medição, com valores entre $21.6^{\circ} \mathrm{C}$ e $22.6^{\circ} \mathrm{C}$.

- No período da manhã, o ponto de medição na praça aberta apresentou uma rápida elevação na temperatura, chegando a atingir valores a cima de $30^{\circ} \mathrm{C}$ a partir das 10h. Da mesma forma, o canyon apresentou elevadas temperaturas de $28^{\circ} \mathrm{C}$ às $10 \mathrm{~h}$ e valores maiores de $30^{\circ} \mathrm{C}$ a partir das $11 \mathrm{~h}$. Por outro lado, os resultados no parque indicaram um aumento mais lento da temperatura, com $26^{\circ} \mathrm{C}$ às $10 \mathrm{~h}$, e valores a cima de $30^{\circ} \mathrm{C}$ somente a partir das $12 \mathrm{~h} 30$.

- No período da tarde, o ponto de medição na praça aberta e o canyon atingiram a temperatura máxima às $16 \mathrm{~h}$, com valores de $35^{\circ} \mathrm{C}$ e $34^{\circ} \mathrm{C}$, respectivamente. Enquanto isso, o parque apresentou para o mesmo horário a temperatura de $32.1^{\circ} \mathrm{C}$. Esses resultados mostram o efeito benéfico da vegetação na redução da temperatura do ar em relação a outros materiais como cimento e asfalto.

- Entre as $8 \mathrm{~h}$ e as $16 \mathrm{~h}$, a umidade relativa do ar seguiu um padrão decrescente, por definição inverso ao aumento da temperatura do ar, para os três casos, sendo que, na situação do canyon e da praça, a umidade oscilou na faixa dos $30 \%$ a $40 \%$. No entanto, a área do parque manteve valores de umidade entre $40 \%$ e $60 \%$. A partir das $17 \mathrm{~h}$, a umidade aumentou chegando a chover logo após o término das medições.

- Em relação à ventilação, tanto no parque como no canyon o vento predominante foi o nordeste (NE), com velocidade média de $0.95 \mathrm{~m} / \mathrm{s}$ e $1.72 \mathrm{~m} / \mathrm{s}$, respectivamente. $\mathrm{Na}$ praça, a direção predominante dos ventos foi noroeste (NO), com velocidade média de $1.5 \mathrm{~m} / \mathrm{s}$.

\footnotetext{
${ }^{58}$ Estávamos em horário de verão.
} 


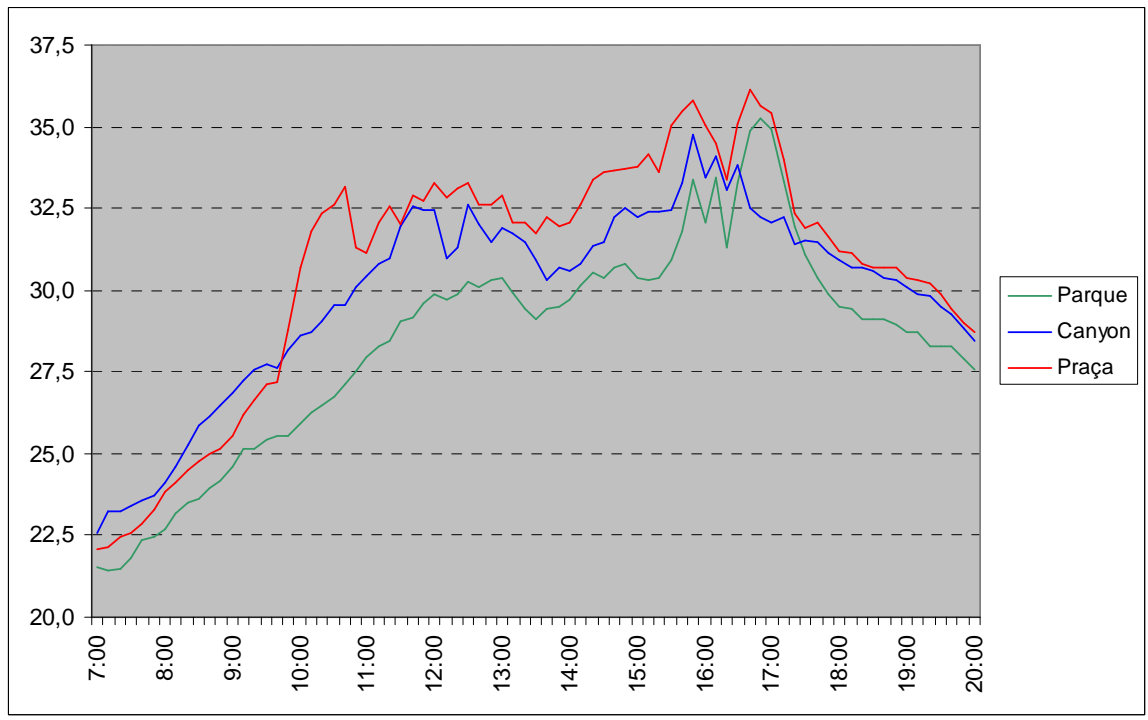

Gráfico 1: Comparativo das temperaturas do ar obtidas na primeira etapa de medição $\left(\mathrm{em}^{\circ} \mathrm{C}\right)$.



Gráfico 2: Comparativo das umidades relativas ao ar obtidas na primeira etapa de medição $(\mathrm{em} \%)$.

\section{Segunda etapa de medição}

- $\quad$ Às $7 \mathrm{~h}$, no inicio da medição ${ }^{59}$, os três pontos apresentam a mesma temperatura, de aproximadamente $17^{\circ} \mathrm{C}$.

- Observa-se que a temperatura do ponto da calçada sofreu uma rápida elevação entre o período entre as $7 \mathrm{~h}$ e as $10 \mathrm{~h}$, atingindo já neste horário a casa dos $30^{\circ} \mathrm{C}$. A diferença significativa deste resultado em relação aos valores obtidos nos dois

\footnotetext{
${ }^{59} \mathrm{Na}$ segunda medição estávamos em horário normal.
} 
pontos do Parque da Luz indica que o ponto da calçada estava recebendo outros ganhos de calor, provavelmente pela fachada da Estação (orientação norte), superestimando a temperatura do ar. Mesmo com o isolamento do sensor, houve o aquecimento do equipamento. Por este motivo, não foram considerados válidos os registros feitos para o ponto da calçada.

- Já nos outros dois pontos no parque a temperatura do ar apresentou uma elevação similar de temperatura, sendo que a do ponto do portão foi aproximadamente até $1^{\circ} \mathrm{C}$ mais elevada do que a do ponto no interior do parque.

- As temperaturas sofreram uma lenta elevação ao longo dia, até as $15 \mathrm{~h}$, atingindo máximos de $27,7^{\circ} \mathrm{C}$ no portão às $14 \mathrm{~h} 40$ e $27,5^{\circ} \mathrm{C}$ no interior do parque, nesse mesmo horário.

- A partir das $15 \mathrm{~h}$, as temperaturas começaram a sofrer uma queda significativa nos três pontos, chegando aproximadamente ao mesmo valor na calçada e no portão, $21^{\circ} \mathrm{C}$, e no parque, a $20^{\circ} \mathrm{C}$.

- As umidades relativas do ar nos três pontos começaram também com valores aproximados de $80 \%$. Observou-se ao longo do dia uma queda brusca na umidade nos três pontos, porém foi evidente o distanciamento dos valores do ponto da calçada para os outros dois. Esse ponto atingiu valores mínimos de $28 \%$, perto do meio dia, enquanto nos outros dois pontos as umidades relativas mínimas não foram inferiores a $40 \%$.

- A partir das $15 \mathrm{~h}$, as umidades relativas do ar começam a subir novamente, atingindo às $17 \mathrm{~h}$ valores similares para os três pontos, de aproximadamente $75 \%$. Os valores absolutos foram calculados também para comparação de resultados.

- Com relação à ventilação, a intensidade média do vento no parque e no portão foi de $0,6 \mathrm{~m} / \mathrm{s}$ e de $0,4 \mathrm{~m} / \mathrm{s}$ na calçada. 


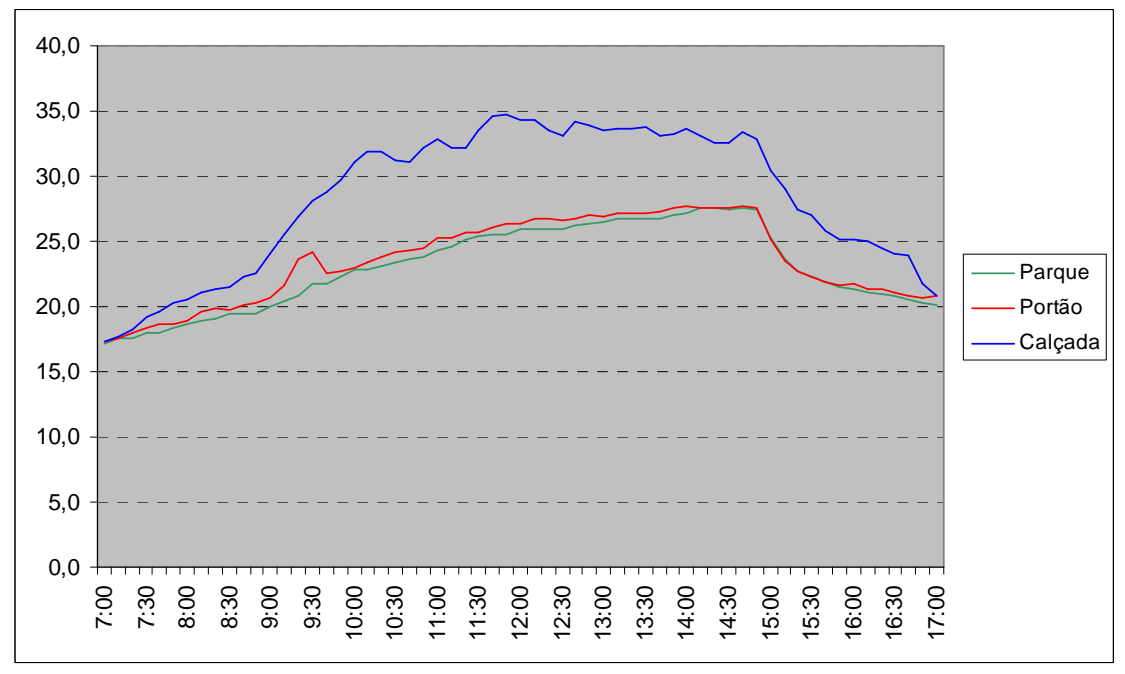

Gráfico 3: Comparativo das temperaturas obtidas na segunda etapa de medição (em $\left.{ }^{\circ} \mathrm{C}\right)$.



Gráfico 4: Comparativo das umidades relativas do ar obtidas na segunda etapa de medição (em\%).

Portanto, com base nestes resultados pode-se verificar o efeito positivo da vegetação no que se refere à amenização das condições climáticas no verão, uma vez que esta contribuiu para a redução da temperatura e aumento da umidade do ar. A situação do canyon e da praça, na primeira etapa, e da calçada, na segunda, demonstram que a substituição das áreas verdes e permeáveis por edifícios e áreas pavimentadas resulta em alterações nos microclimas urbanos, causando, por sua vez, desconforto ambiental para os pedestres em clima tropical. Essas alterações são caracterizadas principalmente pelo 
rápido aumento de temperatura do ar e das superfícies urbanas, enquanto a umidade mantém-se muito baixa. No ponto do portão pode-se observar uma situação intermediária, com condições parecidas com o interior do parque, porém com uma maior redução na umidade relativa do ar e temperatura levemente mais elevada, principalmente no meio do dia.

\subsection{MEDIÇÕES DO ÍNDICE DE ÁREA FOLIAR - LAI}

Foram feitas medições para obtenção dos valores de LAI para duas principais espécies existentes na cidade de São Paulo, segundo a metodologia de Peper e McPherson (1998), a fim de se adaptar o banco de dados do modelo ENVI-met às condições brasileiras. Estas medições foram organizadas juntamente com os pesquisadores Dr. Erik Johansson e MSc. Jörg Spangenberg e apoiada pelo grupo de pesquisa do Laboratório de Conforto Ambiental e Eficiência Energética - LABAUT.

\subsubsection{DEFINIÇÕES DO ÍNDICE DE ÁREA FOLIAR - LAI}

O Índice de Área Foliar ou Leaf Area Index - LAI corresponde à relação da superfície total das folhas da copa $\left(\mathrm{m}^{2}\right)$ pela área de superfície do solo $\left(\mathrm{m}^{2}\right)$ na projeção de copa. Um importante parâmetro para se para verificar a interação entre atmosfera e superfície do solo é a troca de energia pelas folhas das árvores (Meir, 2000). O LAI é um número adimensional e ajuda a medir o crescimento da planta, influenciando diretamente na interceptação e absorção da luz na copa, assim como no balanço das trocas de calor e taxas de evaporação com a atmosfera (Figura 72).

Segundo Ometo (1981), à medida que a cultura vai crescendo aumenta o número de folhas e, dessa maneira, com o aumento da superfície foliar e do número de folhas utilizadas na fotossíntese, cresce a absorção de $\mathrm{CO}^{2}$, estimulando cada vez mais a evapotranspiração, resultando em acréscimo de matéria seca, que sintetiza todas as relações planta-meio.

Este índice está relacionado a uma série de processos ecológicos como fotossíntese e evapotranspiração, possibilitando a previsão das taxas de trocas de energia entre vegetação e atmosfera, a curva de crescimento futuro e as diferenças na estrutura da copa devido à poluição do ar e mudança climática (Ong, 2002). Assim, este índice está muito ligado à fisiologia e aos processos biológicos da folha e influenciam diretamente 
no microclima local por meio das trocas de calor latente e do processo de evapotranspiração.
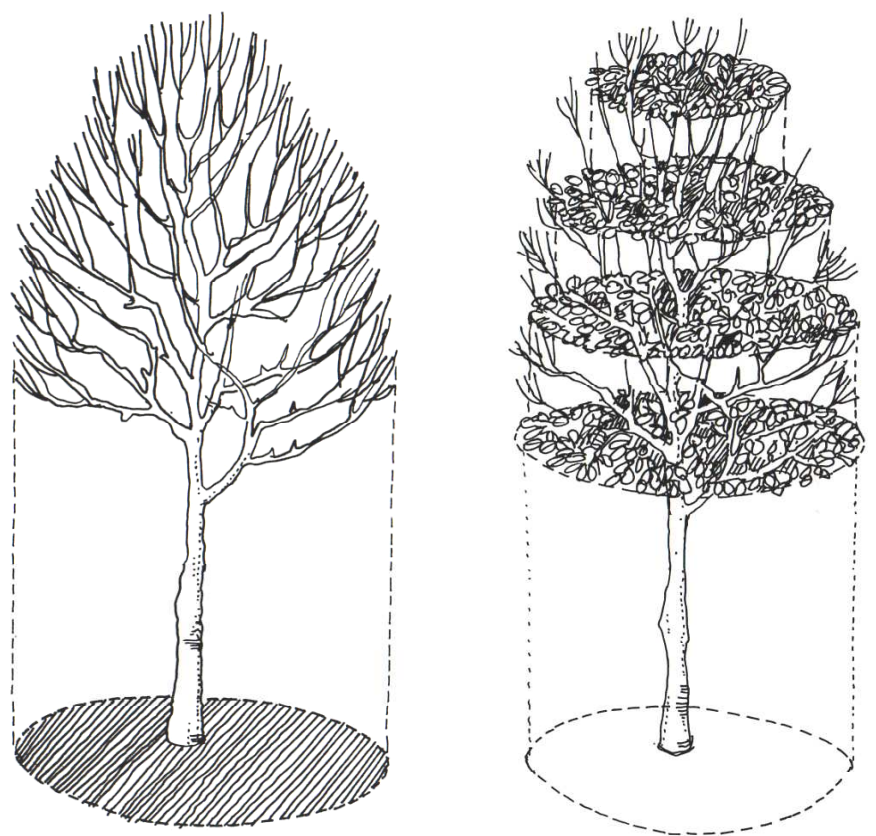

Figura 71: Projeção do diâmetro da copa.

Figura 72: Exemplo de LAI - Distribuição da quantidade de folhas em relação ao diâmetro da copa.

Fonte: Townbridge e Bassuk (2004).

Além disso, este índice tem aplicações práticas no planejamento urbano como demonstra Ong (2002) em projetos na China e Cingapura e baseados no conceito do Green Plot Ratio (Relação Área Verde/ Área).

O Green Plot Ratio, GPR, é definido como uma média do LAI em uma determinada área arborizada. Também equivale à relação da área total de folhas existentes pela área total. O GPR é um indicador do efeito da vegetação, mais efetivo do que o cálculo da cobertura vegetal, pois está diretamente relacionado com a quantidade de folhas que realizam fotossíntese no local (Ong, 2002).

\subsubsection{DEFINIÇÕES DA DENSIDADE DE ÁREA FOLIAR - LAD}

O Índice de Densidade Foliar ou Leaf Area Density - LAD é determinado pela distribuição vertical das folhas em camadas horizontais; o LAD é definido pela relação entre a área de folha pela quantidade total de folhas em $1 \mathrm{~m}^{3}$ de copa e, de acordo com 
Hosoi e Omasa, (2006) para um determinado tamanho de copa, a área total das folhas depende da média do LAD e de sua distribuição, sendo uma importante influência no regime de radiação solar. O LAD depende de diferentes macro-componentes (densidade que depende da relação tipo dos galhos) e micro-componentes (o comprimento da copa, número de folhas pela dimensão da copa e tamanho das folhas) e sua resposta em relação ao regime da radiação local (Lalic e Mihailovic, 2004).

A distribuição espacial do LAD é o parâmetro chave para se descrever as características das copas de árvores e mostrar o forte impacto no seu balanço de radiação e trocas de energia com a atmosfera (Lalic e Mihailovic, 2003). Da mesma forma, os valores de $\mathrm{LAD}$, além de indicarem processos fisiológicos da planta (devido à concentração das folhas), também informam sobre a atenuação da radiação solar. Este fator contribui para o sombreamento e tem um efeito no conforto térmico dos pedestres, principalmente em cidades de clima tropical.

O modelo ENVI-met, ao invés de utilizar diretamente os valores do LAI das árvores, trabalha com o os valores da Densidade de Área Foliar, LAD, (Leaf Area Density) nos cálculos de evapotranspiração e balanço de energia. No banco de dados de vegetação do programa, o LAI total é soma da densidade foliar existente em cada camada da árvore. A Figura 73 mostra um exemplo de árvore em que a copa começa $4 \mathrm{~m}$ acima do solo e somando os valores de cada camada, tem-se um LAI = 10 .

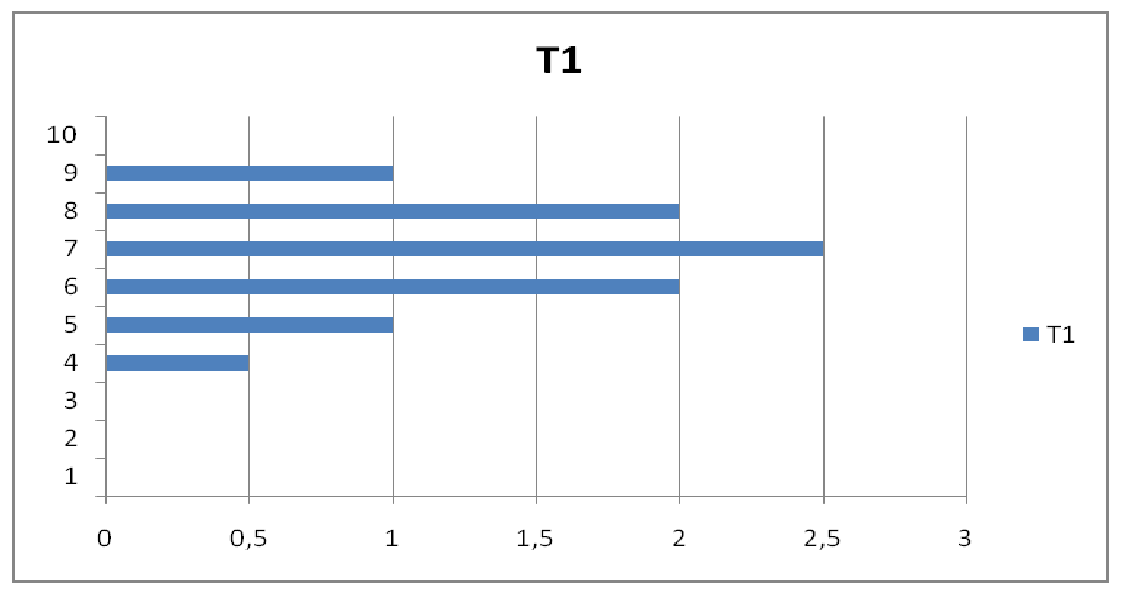

Figura 73: Perfil do LAD proposto para uma árvore com $L A I=10$. No eixo $x$ os valor de LAD e no eixo y a altura da cada camada em metros. 


\subsubsection{METODOLOGIAS DE CÁLCULO DO LAD E LAI}

O ENVI-met sugere o cálculo estimado do LAD por meio da distribuição do valor máximo de $\mathrm{LAD}$ de acordo com a altura da árvore. No caso de valores mais precisos o modelo indica duas metodologias: medições e métodos analíticos (Bruse, 2003).

Considerando que o LAD é calculado segundo a diferença entre o LAI medido a uma altura $(\mathrm{H})$ e o valor do LAI a uma altura $(\mathrm{H}-1 \mathrm{~m})$, pode-se deduzir os valores de LAD baseados nas medidas de LAI ao longo da copa. Nesse sentido, foram estudadas as principais metodologias para se determinar o LAI de diferentes espécies.

Os métodos de medição do LAI podem ser classificados em duas principais categorias: métodos destrutivos diretos e métodos não-destrutivos indiretos. $\mathrm{O}$ método direto baseia-se no cálculo da área média de folhas individuais coletadas e, a partir destes dados, estima-se o LAI para toda a copa da árvore. O método indireto envolve medidas de transmissão de luz através da copa das árvores e medições por sensores remotos do albedo.

Nas medições, o LAI pode ser obtido por meio de métodos ópticos. Apesar de rápido, este método não mostra a distribuição vertical das folhas. Por meio de métodos empíricos é possível se chegar ao valor do LAI, usando sensor óptico em diferentes alturas da copa.

Yu e Hien (2005) obtiveram os índices de LAI por meio de medições de campo com o equipamento LAI-2000 Plant Canopy Analyzer. Este equipamento calcula o LAI pelas medidas de radiação feita com um sensor óptico acoplado a uma lente grande angular $\left(148^{\circ}\right)$. As medidas são feitas acima e abaixo da copa para se determinar a interceptação da luz em cinco ângulos, sendo o LAI gerado por meio de modelos de transferência de radiação nas copas das árvores. Apesar do método ser não-destrutivo e da automática estimativa do LAI, o LAI-2000 Plant Canopy Analyzer (Figura 74) considera a distribuição das folhas de forma aleatória, o que gera uma baixa estimativa quando as folhas estiverem mais agrupadas ou sobrepostas. Além disso, os cálculos são precisos apenas para a luz indireta que atravessa a copa, sendo que a luz direta induz a erros nessas estimativas (Hosoi e Omasa, 2006). 


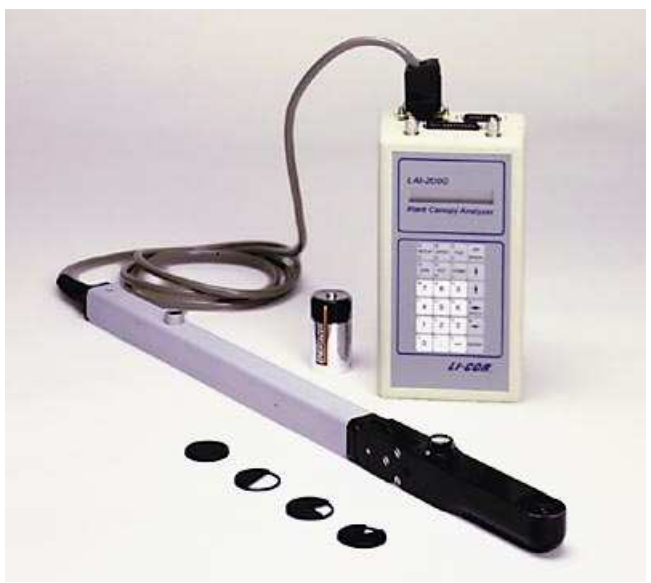

Figura 74: Equipamento LAI-2000 Plant Canopy Analyzer.

Fonte: Disponível em http://www.licor.com/env/Products/AreaMeters/lai2000/2000_intro.jsp. Acesso em agosto de 2007.

Hosoi e Omasa (2006) aplicaram a técnica 3D de sensores remotos com o instrumento Lidar (light detection and ranging) acoplado em aviões que fazem o levantamento de uma área florestal emitindo e recebendo impulsos a laser. Esta técnica vem sendo utilizada para estimar o perfil vertical da superfície das copas das árvores. Junto com as informações obtidas em grande escala, um sistema Lidar portátil foi colocado no nível do solo para complementar dos dados obtidos pelo avião e gerar os perfis de LAI mais exatos possíveis.

Além dos métodos direto e indireto, Ometo (1981) indica o cálculo do LAI a partir de fotografias hemisféricas. A foto deve ser feita num dia com radiação difusa e utiliza corpo de máquina de filme 24 x $35 \mathrm{~mm}$ e lente olho-de-peixe com $180^{\circ}$ de visão. $\mathrm{O}$ autor sugere no mínimo 10 fotos por parcela para se estimar o LAI.

Segundo Ong (2002), existem três principais formas de se obter o valor de LAI:

- O valor estimado para o LAI pode ser obtido pela Lei de Beer-Lambert, que define uma relação empírica entre a absorção da luz e as propriedades dos materiais por onde a luz passa. A Lei de Beer-Lambert assume que a luz é atenuada exponencialmente ao atravessar a copa de uma árvore e segundo um coeficiente $k$. A luz medida embaixo da copa está relacionada com a luz sobre a copa, e o LAI é dado pela seguinte equação:

$$
Q i=Q o \mathrm{e}^{-\mathrm{kLAI}}
$$




\section{Onde:}

$Q \boldsymbol{Q}=$ embaixo da copa

$Q \boldsymbol{Q}=$ luz sobre a copa

LAI = leaf área index

- Baseados nos estudos de Peper e McPherson (1998), o método fotográfico pode determinar os valores de LAI pelo perfil das árvores. Os vazios existentes nas copas permitem a passagem da luz e sua intensidade é comparada com outras partes da copa até se chegar na penetração média do raio solar. Os resultados mostram a distribuição média das folhas e determinam os valores estimados de LAI.

- Os trabalhos de Green and Clark (2000) mostram o uso imagens de satélite por sensores remotos, relacionando o Índice da Diferença Normalizada da Vegetação (Normalized Difference Vegetation Index, NDVI) e o LAI. O NDVI é calculado segundo os valores das bandas vermelha e infravermelha, entre 666.5 e $752.8 \mathrm{~nm}$, das fotografias de satélites.

\subsubsection{PROCESSO DE MEDIÇÃO DO LAI UTILIZADOS E}

\section{RESULTADOS}

A obtenção dos valores de LAI nesta pesquisa seguiu os seguintes passos:

1. Foram fotografadas duas espécies arbóreas individualmente em dois lados perpendiculares com câmera Canon a uma distância entre 15 e 25 m, tendo sempre ao lado uma referência em relação à altura (bastão em madeira de $2.0 \mathrm{~m}$ ) e área (quadrado em papelão de $25 \mathrm{~cm}$ x $25 \mathrm{~cm}$ ). Estas referências servem para definir os dados de altura, diâmetro da copa (Figura 75). Estas fotos foram feitas no Parque Ibirapuera no período da primavera (dia 22/ 10/ 2007).

2. Cada imagem foi tratada com a ajuda do programa Adobe Photoshop, eliminandose o fundo e deixando-se apenas a copa. (Figura 76).

3. O cálculo do LAI é determinado pela equação:

$$
\mathrm{LAI}=\left(\begin{array}{lll}
\mathrm{SA} & \mathrm{x} & \mathrm{CFA}
\end{array}\right) / \mathrm{PCA}
$$

Onde: 
SA = Silhouette Area . É definida como a porcentagem da imagem que representa a copa da árvore na foto, sendo este valor obtido pela relação da quantidade de pixels na copa pelo total de pixels na foto. O programa Sigma $S c a n^{60}$ foi utilizado na contagem dos pixels (Figura 77)

PCA= Projection Crown Area (Projeção da copa em $\mathrm{m}^{2}$ ).

CFA= Crown Frame Area. Ao se definir uma moldura que contém a área total da copa (Figura 72), o CFA é determinado por meio da equação:

$\mathrm{CFA}=[(\mathrm{L} \times \mathrm{d}) / \mathrm{c1}] \times[(\mathrm{A} \times \mathrm{d}) / \mathrm{c} 2]$

Onde:

L: largura da copa na moldura

d: distância em relação à árvore

c1: comprimento focal da câmera em relação à largura da foto

c2: comprimento focal da câmera em relação à altura da foto

A: altura da copa na moldura
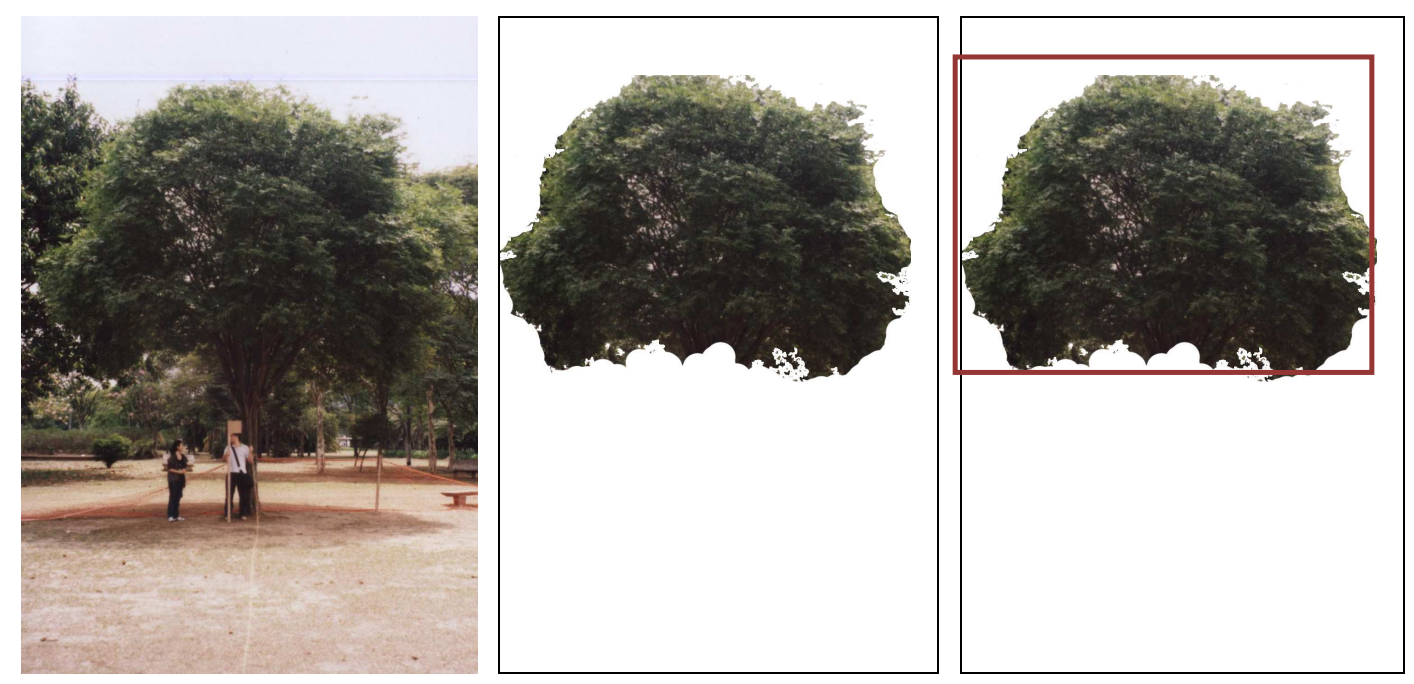

Figura 75: Medição LAI - Fotografia da árvore inteira a uma distância de 20m.

Figura 76: Medição LAI - Tratamento da foto, deixando apenas a copa.

Figura 77: Medição LAI - Criação da moldura no entorno da copa.

${ }^{60}$ Sigma Scan. Disponível em: < http://www.systat.com/products/SigmaScan/ $>$. Acesso em junho de 2008. 
Como resultados da aplicação da metodologia de Peper e McPherson (1998) para as espécies arbóreas, foram obtidos LAI 3 para o alecrim-de-campinas (Holocalyx balansae) e LAI 1 para o pau ferro (Caesalpinia leiostachya), no período da medição.

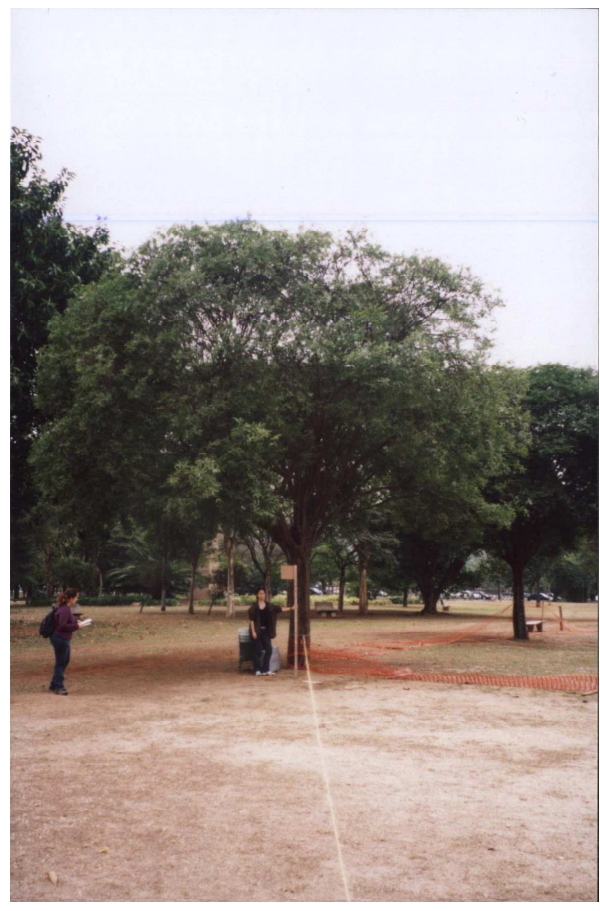

Alecrim-de-campinas LAI $=3$

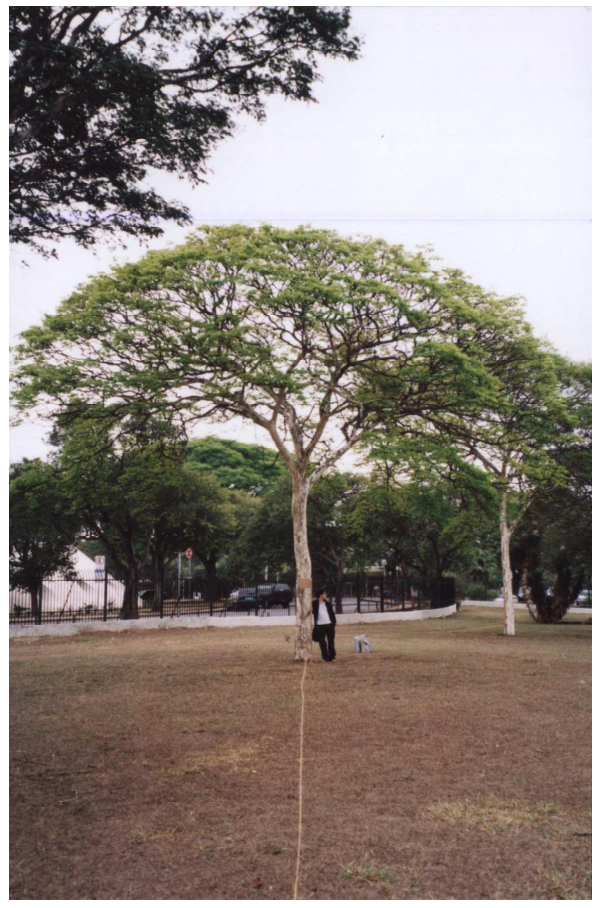

Pau ferro LAI $=1$

Essas espécies foram definidas segundo o levantamento das árvores de médio e grande porte aconselhadas para o plantio nas vias públicas pela Prefeitura Municipal de São Paulo. Os pesquisadores da ESALQ, coordenados pelo prof. Dr. Demóstenes Ferreira da Silva Filho, contribuíram na discussão sobre as possíveis metodologias de medição do LAI e escolha das espécies. O grupo de pesquisa de silvicultura urbana da ESALq tem desenvolvidos projetos voltados para a avaliação da qualidade da arborização urbana e nesse sentido o índice de área foliar é um importante parâmetro para verificar o crescimento das árvores e quantificar seus benefícios. 


\section{SIMULAÇÕES PARAMÉTRICAS NO ENVI-MET SEM VEGETAÇÃO}

Os estudos dos modelos paramétricos foram desenvolvidos por meio do programa ENVI-met e com a colaboração dos pesquisadores Dr. Erik Johansson e MSc. Jörg Spangenberg, do LABAUT.

Johansson (2006), vinculado à Lund University, na Suécia, concluiu recentemente o programa de Pós-doutorado na FAUUSP, sob a supervisão da prof. Dra. Denise Duarte. Em seus estudos de doutoramento aplicou o modelo ENVI-met para avaliar a influência de diferentes parâmetros climáticos no projeto urbano, avaliando o conforto térmico em canyons urbanos para cidades de clima quente, dando continuidade às aplicações feitas anteriormente para Fez (Marrocos) e Colombo (Sri-Lanka).

Spangenberg (2004), vinculado à Bauhaus Universität, na Alemanha, e atualmente cursando o doutorado em programa sanduíche no LABAUT/FAUUSP, sob a orientação da Prof. Dra. Márcia Alucci, desenvolve estudos sobre alterações climáticas provocadas pela presença de vegetação na cidade de São Paulo, utilizando também o modelo ENVImet. Em função de contatos anteriores na Alemanha com o autor do modelo, Prof. Michael Bruse, a pesquisa de Spangenberg vai introduzir modificações no programa que se fazem necessárias para simulações sob condições tropicais, com a colaboração do autor. A pesquisa anterior de Spangenberg, desenvolvida no programa de Mestrado na PUC - Pontifícia Universidade Católica do Rio de Janeiro, sobre vegetação urbana na cidade do Rio, teve como tema: Improvement of urban microclimate in tropical metropolis- A case study Maracanã.

\subsection{MODELAGEM}

Os resultados das medições na área da Luz serviram com base para organizar as simulações no ENVI-met. A partir do estudo da área foi definida inicialmente uma geometria simplificada de quatro quarteirões de $60 \mathrm{~m}$ x $60 \mathrm{~m}$, com edifícios de $26 \mathrm{~m}$ de altura (8 pavimentos). A área entre os edifícios é de $12 \mathrm{~m}$, sendo $3 \mathrm{~m}$ de calçada e $6 \mathrm{~m}$ de rua. A relação de H/W é de 2. Apesar dessa configuração homogênea não ser similar ao encontrado no bairro da Luz, ajudou a avaliar os uso de materiais na superfície dos edifícios e das vias. 
A configuração do modelo está dividida em de células com dimensões de $3 \mathrm{~m}$ x $3 \mathrm{~m}$ x $3.75 \mathrm{~m}$ e $27 \mathrm{~m}$ de nesting grid em cada lado da área de estudo. $\mathrm{O}$ tamanho total do modelo ficou com $186 \mathrm{~m}$ x $186 \mathrm{~m}$ e $62,5 \mathrm{~m}$ de altura.

\subsection{ESTUDOS INICIAIS}

As primeiras experiências no ENVI-met utilizaram valores aproximados para ajustar os dados de entrada e, em cada simulação, apenas um parâmetro era alterado de cada vez, possibilitando verificar o efeito de cada variável no resultado final.

O objetivo dos estudos preliminares foi de ajustar os valores obtidos nas medições com os resultados gerados pelo ENVI-met ainda sem a inclusão da vegetação. Antes de iniciar as simulações de vegetação urbana era fundamental definir um modelo compatível com as condições microclimáticas do local. Os resultados de umidade, temperatura do ar e de superfície foram comparados com as medições do canyon em 19 de dezembro de 2006. Três receptores (R1, R2, R3) foram colocados em pontos estratégicos do modelo para fornecer informações detalhadas da temperatura do ar e da superfície.

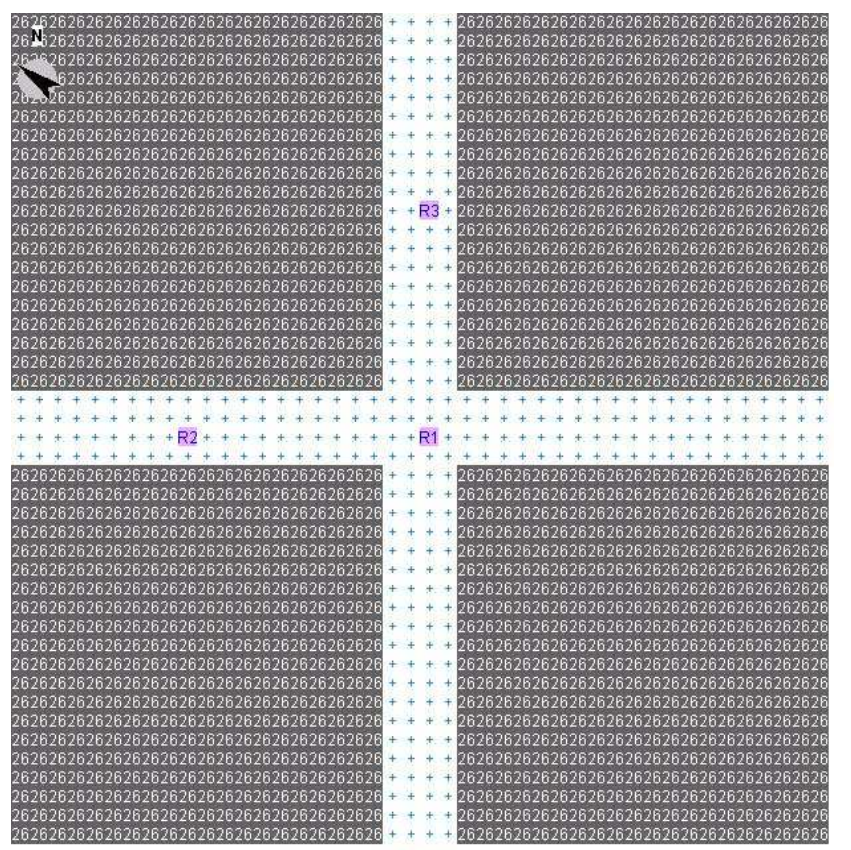

Figura 78: Modelo de Simulação com três receptores.

Foram feitas investigações nos seguintes parâmetros: 
- Velocidade dos Ventos

- Umidade Relativa (com altura de $2 \mathrm{~m}$ e $2500 \mathrm{~m}^{61}$ )

- Área dos nesting grids (tipos de materiais)

- Temperatura inicial do ar

- Temperatura dentro dos edifícios

- Albedo (solo, fachada e cobertura dos edifícios)

- Coeficiente global de transmissão térmica das fachadas dos edifícios

\subsection{RESULTADOS}

A primeira simulação do modelo paramétrico no ENVI-met teve como configuração de entrada os dados obtidos nas medições realizadas em dezembro de 2006. De início surgiram dúvidas para se definir as propriedades dos materiais (albedo, tipo de solo) e outras variáveis climáticas (velocidade dos ventos, temperatura inicial e umidade relativa).

Observa-se uma significativa diferença nas curvas de temperatura do ar (figura 79) e de superfície (figura 80), ao se comparar os resultados da simulação com os valores medidos na Luz. Neste sentido as simulações preliminares serviram para investigar as principais variáveis e ajustar os dados de entrada do ENVI-met.

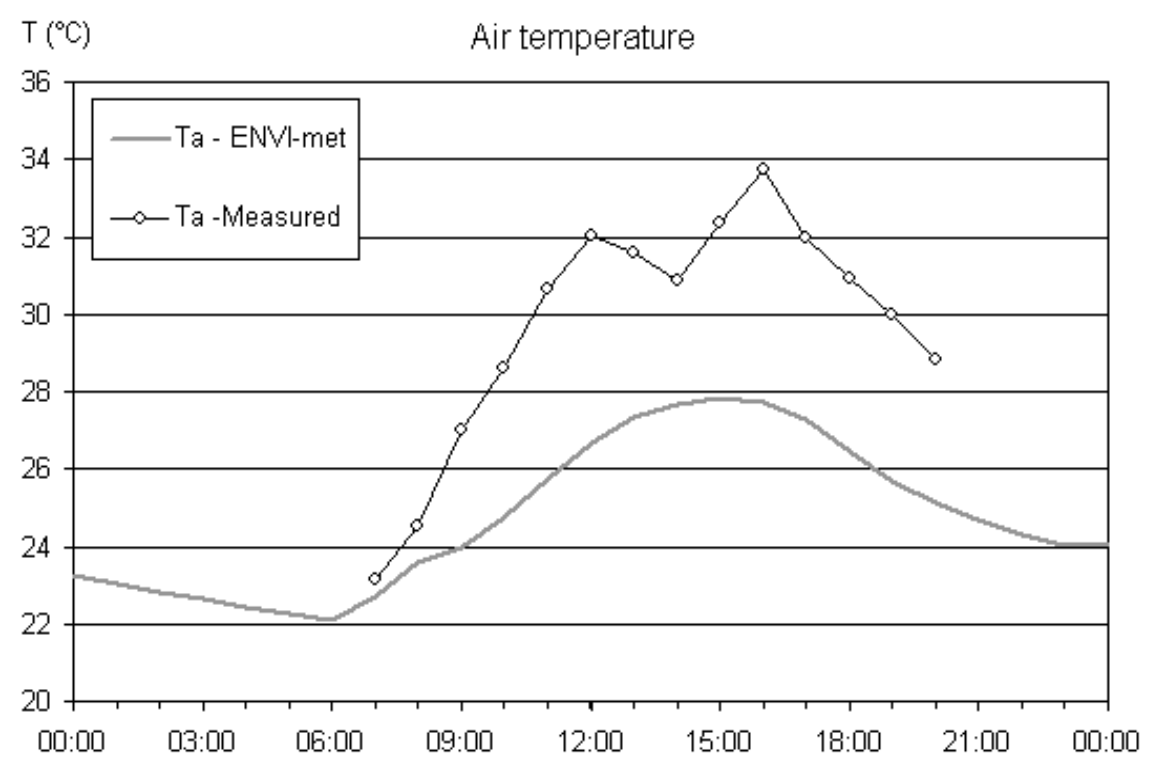

Figura 79: Comparação das temperaturas do ar medidas e simuladas (configuração inicial).

\footnotetext{
${ }^{61}$ A altura de $2500 \mathrm{~m}$ foi uma exigência do programa.
} 


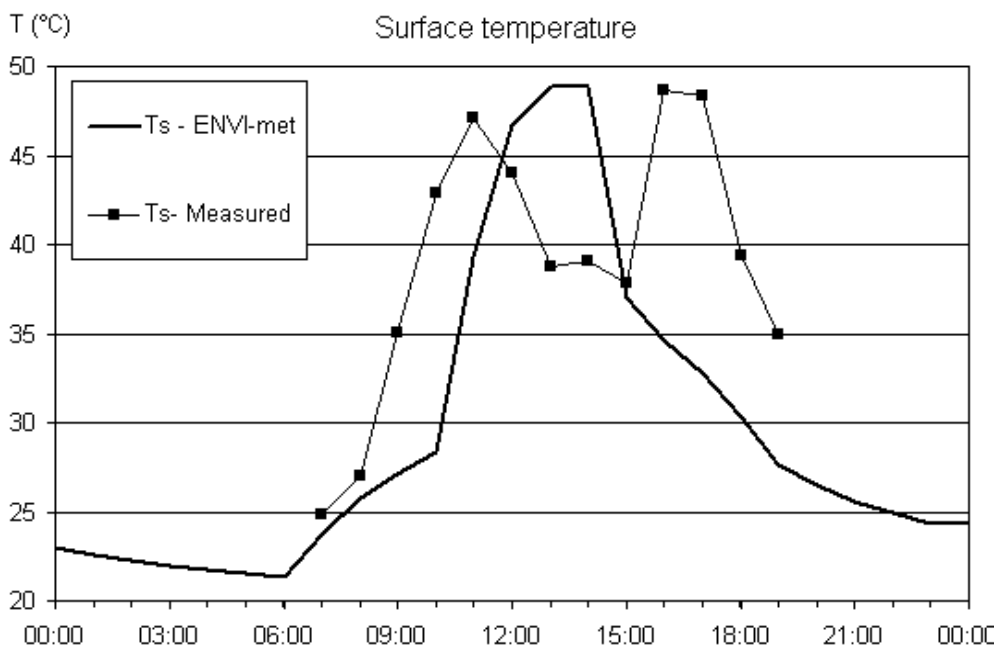

Figura 80: Comparação das temperaturas de superfície medidas e simuladas (configuração inicial).

As principais variáveis que influenciaram diretamente nos resultados obtidos nas simulações para temperatura do ar foram os valores da velocidade dos ventos, nesting grids, temperatura inicial e umidade relativa do solo.Os valores de umidade relativa do solo foram aplicados apenas nos nesting grids e a intenção era de influenciar na temperatura superficial do modelo e, por sua vez, na temperatura do ar.

\subsubsection{Velocidade dos Ventos}

Nas primeiras simulações realizadas, o valor da velocidade do vento adotado era de 1.6 $\mathrm{m} / \mathrm{s}$. Este valor foi definido a partir do cáculo da velocidade média do vento durante o dia da medição. Com esse dado de entrada, a curva de temperatura do ar simulado no ENVI-met não alcança os $28^{\circ} \mathrm{C}$ medidos no canyon, apresentando uma diferença de de cerca de $4^{\circ} \mathrm{C}$.

Com o objetivo de diminuir esta diferença, foram sugeridas quatro novas situações, variando-se apenas a intensidade dos ventos. Os valores propostos de $0.5 \mathrm{~m} / \mathrm{s}, 0.8 \mathrm{~m} / \mathrm{s}$, $1.0 \mathrm{~m} / \mathrm{s}$ e $2.0 \mathrm{~m} / \mathrm{s}$ foram definidos para se avaliar o comportamento do modelo urbano e qual a influência dos ventos nos estudos paramétricos.

A figura 81 mostra os resultados obtidos para a temperatura do ar. Observa-se que a curva para a velocidade de $0.5 \mathrm{~m} / \mathrm{s}$ não aparece, pois a simulação ficou instável e não conseguiu gerar os resultados. As curvas de temperatura seguem a mesma configuração e os valores mais elevados ocorrem quando os ventos estão menos intensos. Mesmo 
assim existe uma diferença de $3^{\circ} \mathrm{C}$ com a tempertura medida na Luz para o mesmo horário (15h). Comparando-se estes resultados com as medições, as curvas dos ventos de $0.8 \mathrm{~m} / \mathrm{s}$ e $1.0 \mathrm{~m} / \mathrm{s}$ são as que mais se aproximam dos valores medidos.

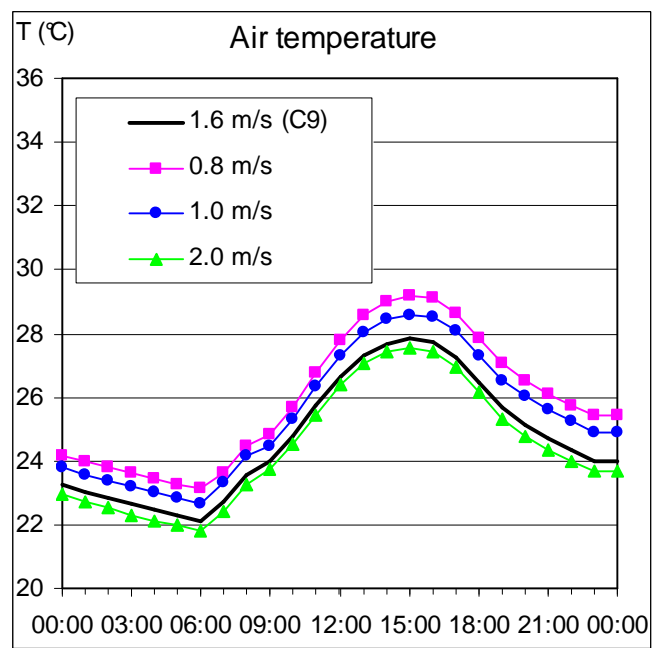

Figura 81: Resultados de temperatura do ar para as diferentes velocidades do vento.

\subsection{2 Área dos Nesting Grids}

A área dos nesting grids são expansões laterais em volta do modelo para se evitar a instabilidades nas bordas e na sua configuração. Existe a possibilidade de se inserir dois tipos de materiais com uma distribuição no formato de tabuleiro de xadrez. Dependendo do tipo e das propriedades, o material escolhido pode gerar um maior aquecimento do solo e influenciar as temperaturas internas do modelo.

Foram propostas três novas situações: primeiramente, uma supefície de asfalto e terra; a segunda com asfalto e concreto e a última somente com solo seco. A figura 82 mostra os resultados para a temperatura do ar, sendo que a situação com asfalto e solo tem maior potencial de aquecimento, chegando a quase $32^{\circ} \mathrm{C}$. A curva de temperatura do ar para o solo seco gerou resultados muito acima dos valores obtidos na medição, uma diferença acima de $20^{\circ} \mathrm{C}$. 


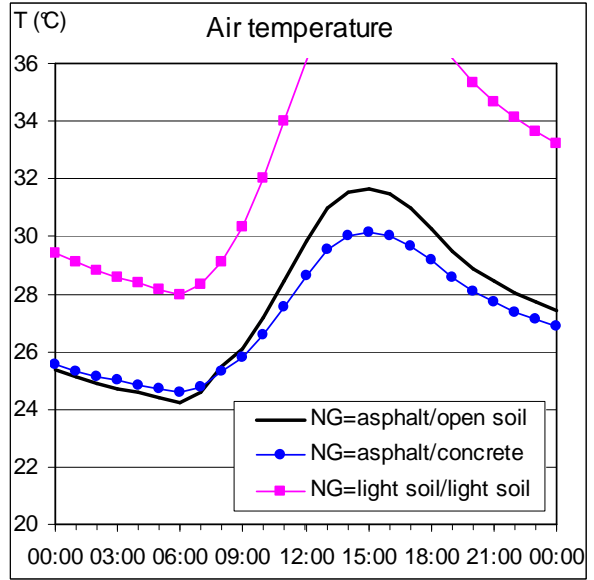

Figura 82: Resultados de temperatura do ar para os diferentes tipos de nesting grids.

\subsubsection{Temperatura Inicial da Atmosfera}

A temperatura do ar medida às $8 \mathrm{~h}$ foi de $23{ }^{\circ} \mathrm{C}(296 \mathrm{~K})$. Foram propostas novas situações, em que as temperaturas iniciais são de $18^{\circ} \mathrm{C}(291 \mathrm{~K})$ e $27^{\circ} \mathrm{C}(300 \mathrm{~K})$.

O objetivo desta investigação era saber o comportamento da curva de temperatura do ar e de superfície, verificando-se a possibilidade de aumentar a amplitude térmica para se aproximar dos valores medidos.

A figura 83 mostra o resultado das temperturas do ar, indicando que as curvas seguem a mesma configuração e amplitude térmica.

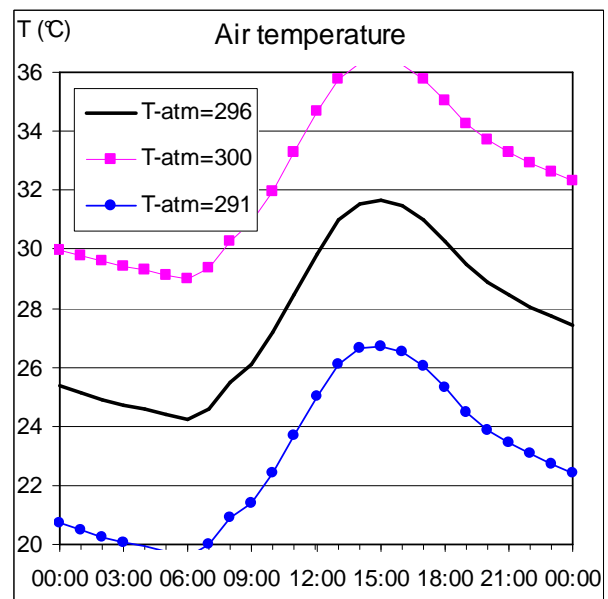

Figura 83: Resultados de temperatura do ar para diferentes valores de temperatura inicial da atmosfera. 


\subsubsection{Umidade Relativa do Solo}

A umidade do solo influencia na sua temperatura superficial e, por sua vez, na temperatura do ar. Os valores de umidade relativa do solo de $25 \%$ e $100 \%$ foram aplicados apenas nos nesting grids. A figura 84 mostra que o aumento nos valores de umidade do solo resulta em maiores amplitudes térmicas ao longo do dia, sendo que a diferença entre os valores máximos às $16 \mathrm{~h}$ é de quase $4{ }^{\circ} \mathrm{C}$. É importante lembrar que o modelo ENVI-met recomenda valores da umidade do solo acima de $40 \%$ em lugares onde existe vegetação. Caso contrário as folhas param o processo de evapotranspiração, fechando os estômatos para evitar a perda de água.

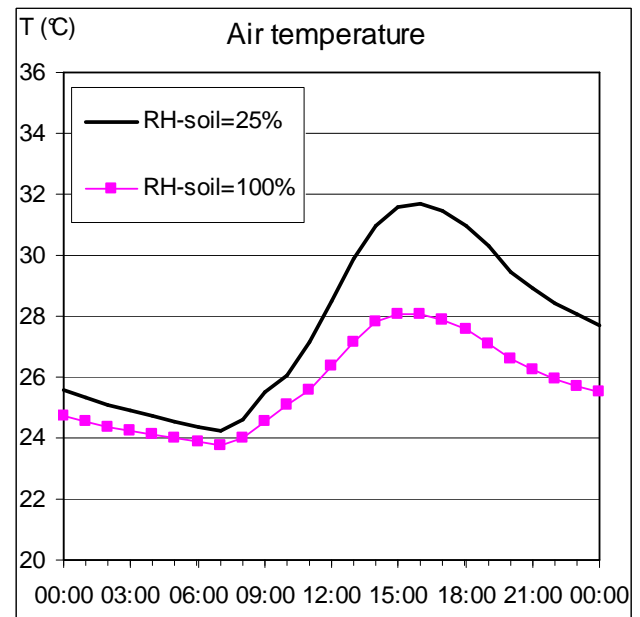

Figura 84: Resultados de temperatura do ar para diferentes valores de umidade relativa do solo.

Por outro lado, os resultados de temperatura do ar para os parâmetros: umidade relativa do ar a $2 \mathrm{~m}$ de altura, temperatura interna dos edifícios, albedo do solo, fachada e cobertura dos edifícios não produziram mudanças em relação à primeira simulação com os dados medidos em campo.

Um dos motivos é a área total dos nesting grids em relação ao modelo, que influencia os resultados mais do que os próprios parâmetros internos. Essa questão foi importante para se verificar o papel dos nesting grids e propor modelos com áreas superiores às bordas externas. 


\subsection{RESULTADOS FINAIS}

Baseados nas simulações preliminares, os dados de entrada do novo modelo, Base Case1 (B1), tiveram a seguinte configuração das variáveis climáticas:

Tabela 4: Descrição dos dados de entrada do modelo ENVI-met.

\begin{tabular}{|l|r|}
\hline Atmosfera & \\
\hline Início das simulações & $7: 00$ \\
\hline Velocidade dos ventos a $10 \mathrm{~m}$ [m/s] & 0.8 \\
\hline Direção dos ventos (em graus) & 170 \\
\hline Temperatura inicial do ar [K] & 297 \\
\hline Umidade Específica a 2500 m [g /kg] & 9.0 \\
\hline Fator de ajuste solar & 0.9 \\
\hline Umidade relativa do ar a 2m [\%] & 70 \\
\hline Edifícios & \\
\hline Albedo das paredes & 0.4 \\
\hline Albedo da cobertura & 0.3 \\
\hline Rua & 0.2 \\
\hline Albedo do solo & \\
\hline
\end{tabular}

A figura 85 mostra os resultados obtidos com o B1 em comparação como os resultados das medições de dezembro de 2006 na área do canyon urbano. 


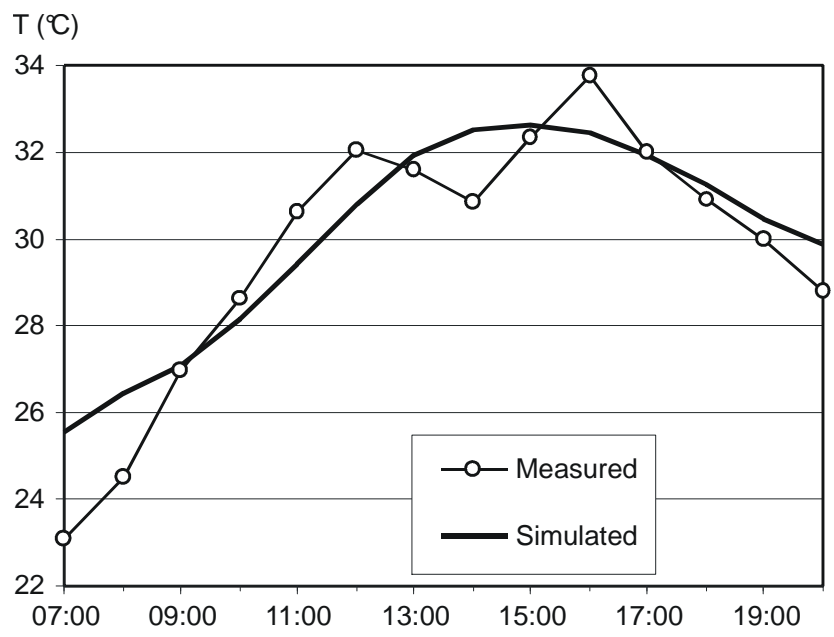

Figura 85: Comparação das temperaturas do ar medidas e simuladas (configuração final B1).

Houve uma aproximação da curva de temperatura do ar do modelo B1 em relação às medições de campo; no entanto, os valores medidos indicam um rápido aumento da temperatura até as $16 \mathrm{~h}$ e resfriamento a partir desse horário. A simulação de B1 apresenta um atraso no aquecimento e resfriamento das temperaturas do ar. Spangenberg (2004) já havia observado este atraso nas simulações do modelo ENVImet durante a pesquisa de mestrado para a área próxima ao Maracanã, no Rio de Janeiro $^{62}$.

Pode-se fazer as seguintes considerações a respeito das limitações do Modelo ENVImet, verificadas durante as simulações preliminares:

- A modelagem urbana está restrita ao formato de grades, não permitindo formas arredondas ou curvas. O modelo também não considera a topografia da área.

- O modelo não permite a armazenagem de calor pelas fachadas dos edifícios, reduzindo a emissão da radiação de onda longa no final do dia.

- Os valores do albedo (parede e cobertura) têm pouca influência no aumento da temperatura do ar.

A próxima etapa foi realizar simulações com modelos paramétricos em diferentes escalas para se verificar o efeito da vegetação segundo diferentes distribuições.

${ }^{62}$ Informação verbal 


\section{SIMULAÇÕES PARAMÉTRICAS NO ENVI-MET COM VEGETAÇÃO}

As simulações paramétricas podem ser divididas em dois grupos: pequena e média escala. Nesses estudos, duas tipologias arbóreas foram utilizadas, uma espécie de copa muito densa T4 (LAI 10) e outra com copa pouco densa e mais permeável T3 (LAI 3). Estes perfis foram obtidos com base nos valores de LAD do banco de dados de vegetação do ENVI-met. Ambas as espécies tem altura total de 10 metros e iniciam sua densidade foliar a partir dos $3 \mathrm{~m}$, a fim de não barrar o fluxo dos ventos no nível do pedestre, até $9 \mathrm{~m}$ acima do solo (Figura 86).
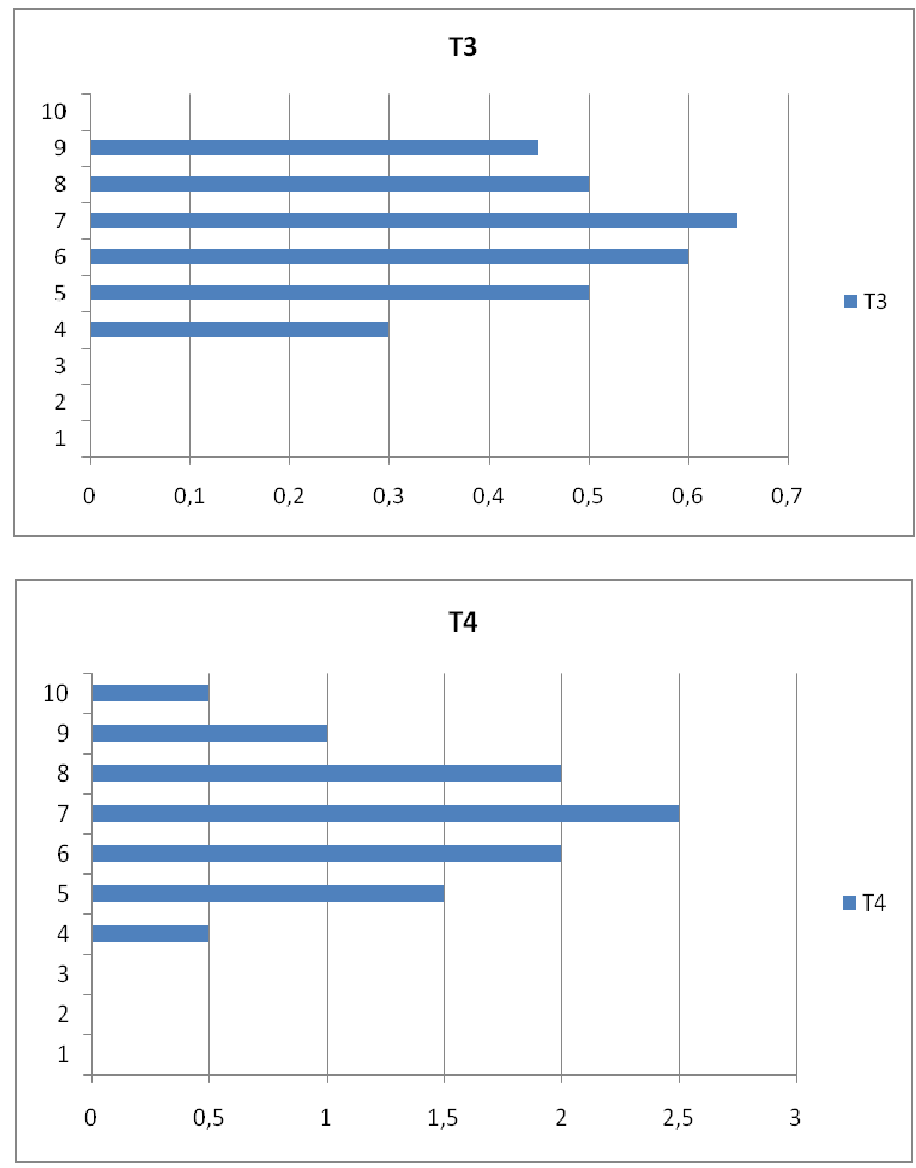

Figura 86: Perfil do LAD proposto para dois tipos de árvores (T3 e T4), no eixo x os valor de LAD e no eixo y a altura da cada camada em metros. 


\subsection{SIMULAÇÕES EM PEQUENA ESCALA}

Os modelos em pequena escala são no total três cenários propostos para se verificar o efeito das gramíneas e das espécies arbóreas T3 e T4, com poucos edifícios no entorno e como os Índices de Área Foliar interferem nos resultados da vegetação.

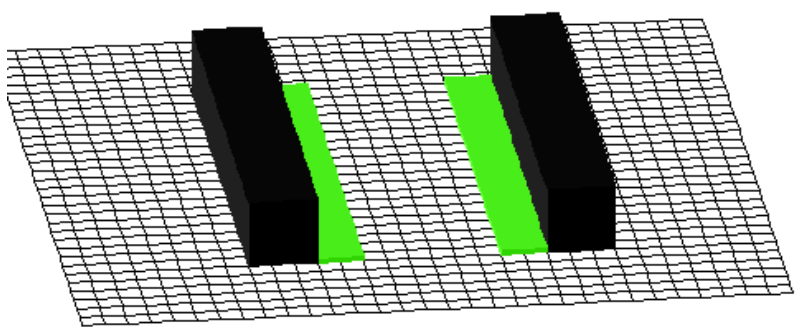

Figura 87: Um canyon formado por edifícios de $24 \mathrm{~m}$ de altura e duas faixas de $160 \mathrm{~m}^{2}(4 \mathrm{~m}$ x 40m) com gramíneas.

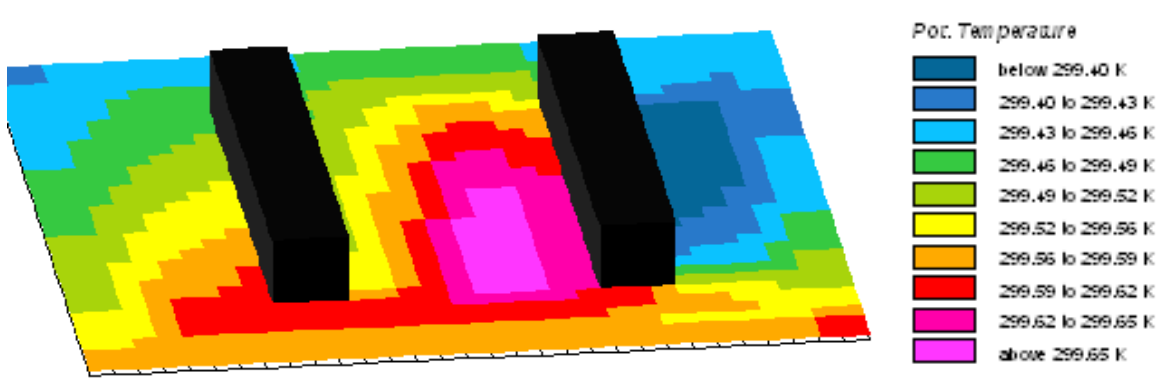

Figura 88: Resultado da simulação ENVI-met para temperatura do ar no cenário 1 às $14 \mathrm{~h}$.
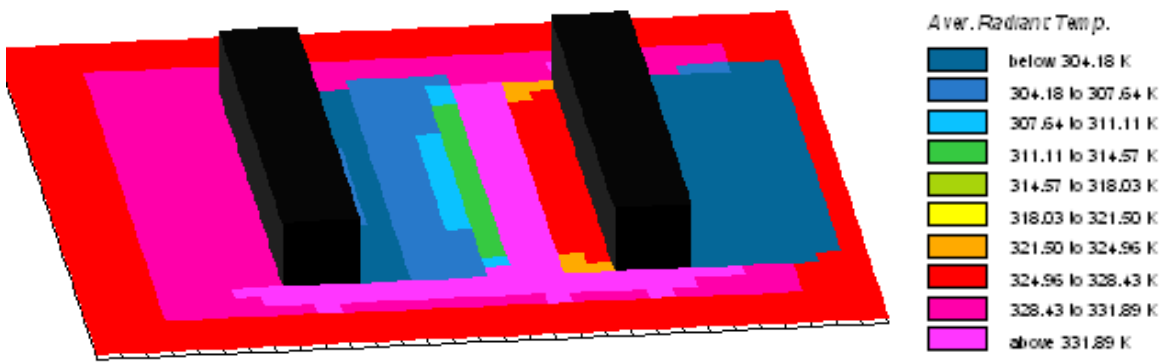

Figura 89: Resultado da simulação ENVI-met para temperatura superficial no cenário 1 às $14 h$.

A Figura 88 mostra os resultados simulados para temperatura ar, no cenário 1 às $14 \mathrm{~h}$. Esse horário foi escolhido por apresentar um dos valores mais altos da temperatura do ar nas medições. Observa-se que a temperatura do ar fica em torno $\operatorname{dos} 26^{\circ} \mathrm{C}$ e existe pouca 
diferença nos valores, no máximo de $0.15^{\circ} \mathrm{C}$, entre a temperatura do ar sobre as gramíneas e a rua. Essa mínima variação ocorre pela constante movimentação do ar.

A simulação seguinte indica que a temperatura superficial da rua chega a $58^{\circ} \mathrm{C}$. A faixa de gramíneas à direita apresenta os melhores resultados com $31^{\circ} \mathrm{C}$, pois combinam os efeitos de evapotranspiração da vegetação com o sombreamento dos edifícios (Figura 89).

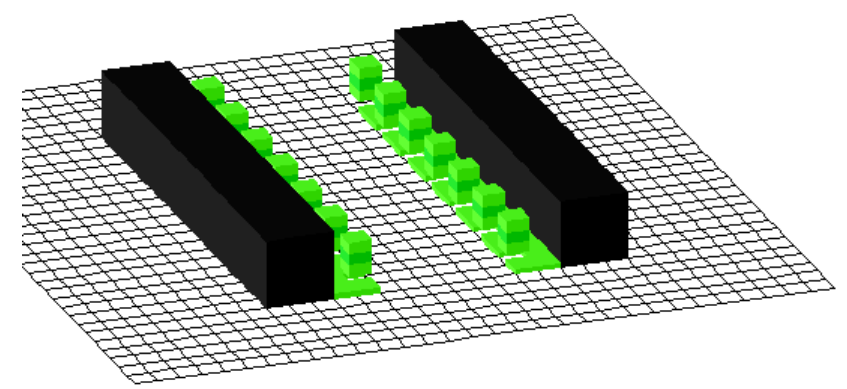

Figura 90: Um canyon formado por edifícios de $24 \mathrm{~m}$ de altura e duas faixas de $160 \mathrm{~m}^{2}(4 \mathrm{~m}$ x 40m) com gramíneas e espécies arbóreas pouco densas (T3), colocadas a cada 4m.
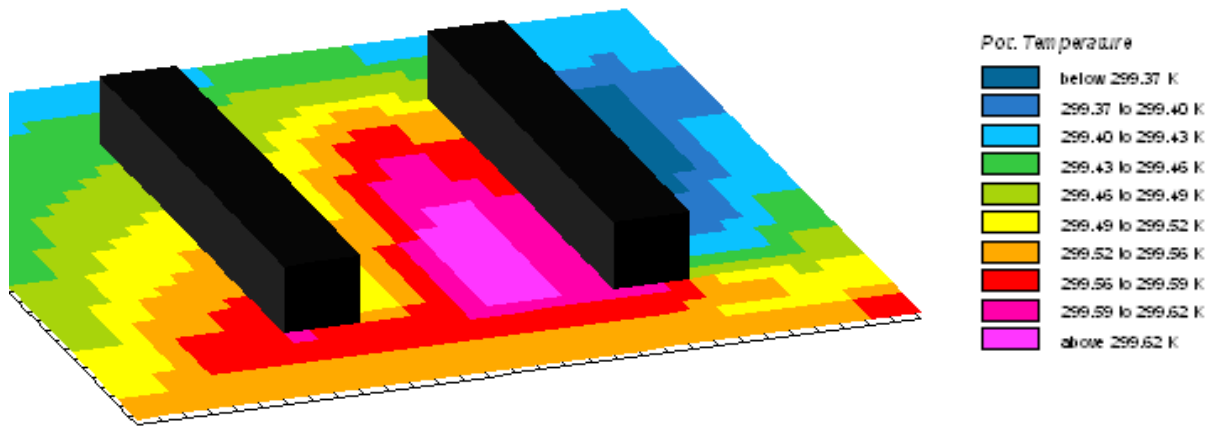

Figura 91: Resultado da simulação ENVI-met para temperatura do ar no cenário 2 às 14 h.

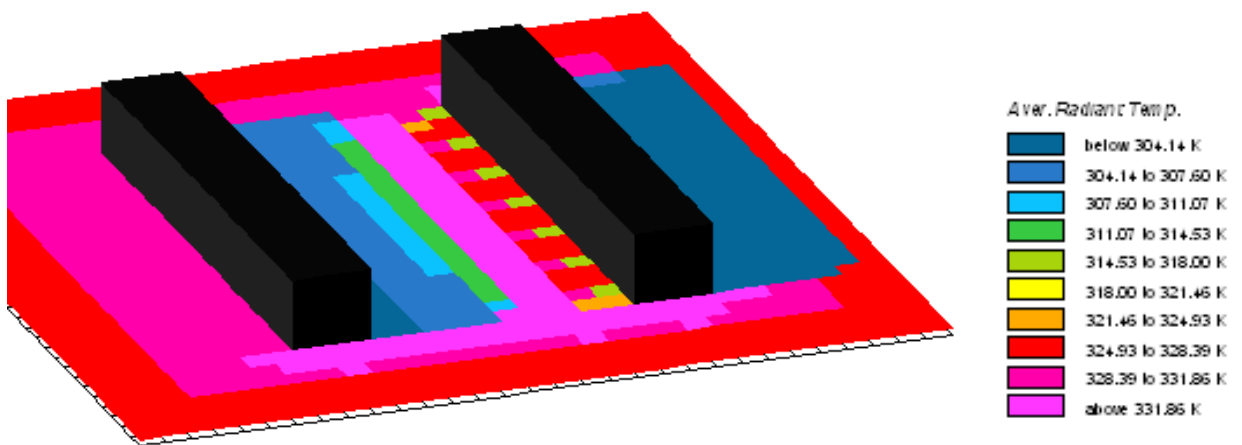

Figura 92: Resultado da simulação ENVI-met para temperatura superficial no cenário 2 às 14h. 
Os resultados para a temperatura do ar mantêm-se basicamente nos $26^{\circ} \mathrm{C}$. Já os valores para temperatura superficial apresentam quatro principais resultados: nas ruas, têm-se os valores mais altos com $58^{\circ} \mathrm{C}$; nas áreas de gramíneas pode-se verificar temperaturas de $52^{\circ} \mathrm{C}$ (sem sombra) e $31^{\circ} \mathrm{C}$ (com a sombra dos edifícios); e nos espaços com árvores $\mathrm{T} 3$, a temperatura é de $41^{\circ} \mathrm{C}$.

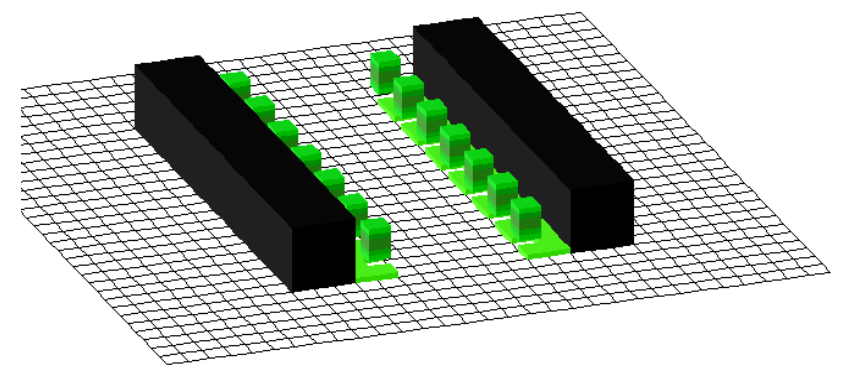

Figura 93: Um canyon formado por edifícios de $24 \mathrm{~m}$ de altura e duas faixas de $160 \mathrm{~m}^{2}(4 \mathrm{~m}$ x 40m) com gramíneas e espécies arbóreas muito densas (T4), colocadas a cada 4m.
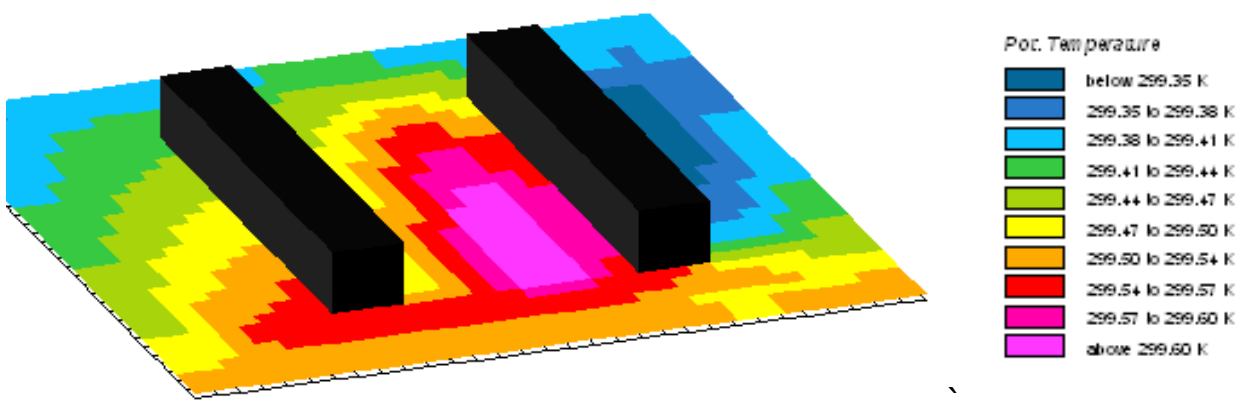

Figura 94: Resultado da simulação ENVI-met para temperatura do ar no cenário 3 às $14 \mathrm{~h}$.

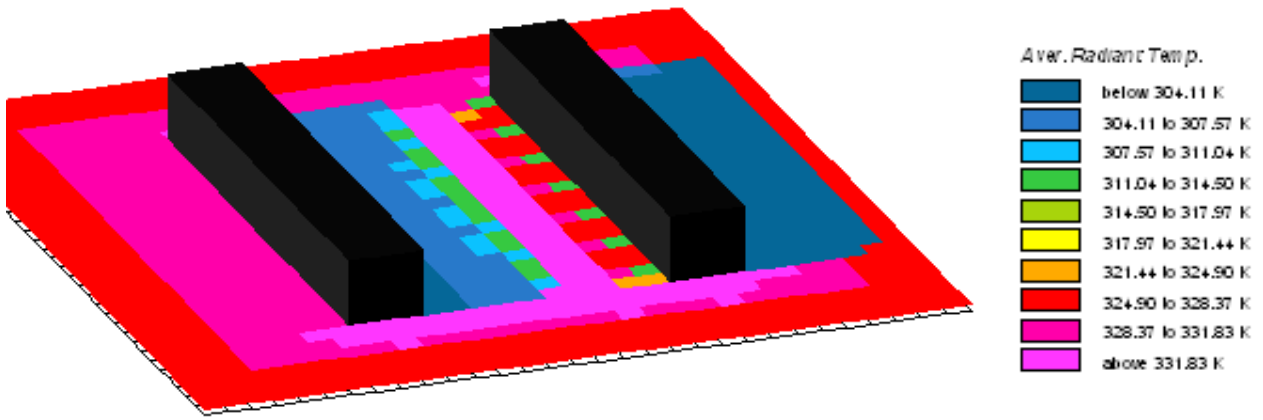

Figura 95: Resultado da simulação ENVI-met para temperatura superficial no cenário 3 às $14 h$. 
No cenário 3, a temperatura do ar permanece a $26^{\circ} \mathrm{C}$ (Figura 94). Os resultados de temperatura superficial são iguais aos obtidos no cenário 2: ruas com $58^{\circ} \mathrm{C}$ e gramíneas entre $52^{\circ} \mathrm{C}$ e $31^{\circ} \mathrm{C}$. Porém, a temperatura superficial para as áreas com árvores T4 é de $38^{\circ} \mathrm{C}$.

Esse resultado mostra a diferença no efeito da vegetação de acordo com a densidade foliar. As gramíneas têm uma influência reduzida, pois não possibilitam o sombreamento pelas copas. Nas árvores, quanto maior o LAI, menor será a temperatura superficial. 


\subsection{SIMULAÇÃO EM MÉDIA ESCALA}

A fim de se explorar os efeitos da vegetação e considerando-se os resultados satisfatórios obtidos nos estudos paramétricos anteriores, foram definidas novas situações de distribuição da vegetação.

A modelagem do Base Case foi definida com base nos parâmetros fornecidos por Brandão (2007), com estudos de dimensão média das quadras, taxa de ocupação e altura média no Bairro de Moema. Estes dados foram adaptados para o tipo de grade existente no ENVI-met, sendo que o modelo final apresenta valores aproximados às informações fornecidas por Brandão (2007) sobre a área edificada de Moema. Esta região foi escolhida apenas para fornecer os dados médios de tamanho das quadras e altura dos edifícios o que não estava disponível para a área da Luz. O modelo é formado por nove quadras de $9600 \mathrm{~m}^{2}$ sem vegetação, com a taxa de ocupação de 0.66 e edifícios com altura de $24 \mathrm{~m}$.

\begin{tabular}{|c|c|c|c|}
\hline Área Média das Quadras $\left(\mathrm{m}^{2}\right)$ & 11432.17 & & 9600 \\
\hline Dimensão $1(\mathrm{~m})$ & 124,15 & & 120 \\
\hline Dimensão 2 (m) & 88.59 & $\begin{array}{l}\text { Dados } \\
\text { adaptados } \\
\text { para o }\end{array}$ & 80 \\
\hline Taxa de Ocupação & 0.53 & ENVI-met & 0.66 \\
\hline Altura Média dos Edifícios (m) & 22.8 & & 24 \\
\hline
\end{tabular}

Figura 96: Definição dos parâmetros de modelagem do Base Case, baseados nos estudos de Fonte: Brandão (2007).

O Base Case manteve a mesma configuração das variáveis climáticas levantadas para a área da Luz, na primeira medição realizada pelos pesquisadores do LABAUT, em dezembro de 2006. A Tabela 5 mostra os principais dados de entrada utilizados.

A partir do Base Case, cinco cenários foram criados com distribuição diferenciada da vegetação: o Cenário 4 com um parque central ocupando uma quadra inteira; o Cenário 5 apresenta um parque linear com um espelho d'água ocupando três quadras 
centrais; o Cenário 6 com pequenos parques presentes em cada quadra; o Cenário 7 com árvores em todas as vias; e o Cenário 8 com vegetação na parte interna da quadra. Nos cenários foram utilizadas árvores densas T4 (LAI=10). Com exceção do Cenário 5, todos os demais tem a mesma quantidade de vegetação, apenas mudando a distribuição. A Figura 97 mostra a estrutura dos cenários propostos para esta simulação.

Tabela 5: Descrição dos dados de entrada do modelo ENVI-met - Modelo Paramétrico com nove quadras

\begin{tabular}{|l|c|}
\hline Start Simulation at Day & 18.12 .2006 \\
\hline $\begin{array}{l}\text { Wind Speed in } 10 \mathrm{~m} \text { ab. Ground } \\
\text { [m/s] }\end{array}$ & 0.8 \\
\hline $\begin{array}{l}\text { Wind Direction } \\
(0: \mathrm{N} .90: \text { E..180:S..270:W..) }\end{array}$ & 170 \\
\hline Initial Temperature Atınosphere [K] & 297 \\
\hline $\begin{array}{l}\text { Specific Humidity in 2500 } \mathrm{m} \\
\text { [g Water/kg air] }\end{array}$ & 9.00 \\
\hline \begin{tabular}{l} 
Relative Humidity in 2m [\%] \\
\hline $\begin{array}{l}\text { Initial Temperature Upper Layer } \\
(0-20 \mathrm{~cm}) \text { [K] }\end{array}$
\end{tabular} & 295 \\
\hline $\begin{array}{l}\text { Relative Humidity Upper Layer } \\
(0-20 \mathrm{~cm}) \text { [\%] }\end{array}$ & 50 \\
\hline
\end{tabular}






Figura 97: Proposta dos cenários para a simulação no ENVI-met.

\subsubsection{RESULTADOS DAS SIMULAÇÕES}

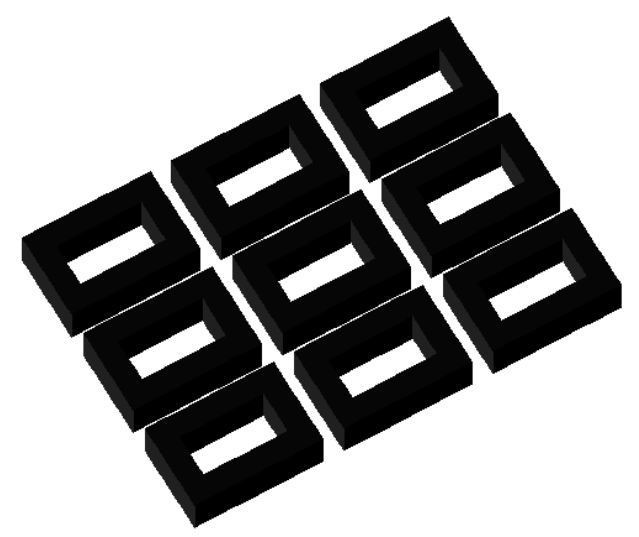

Figura 98: Modelo 3D do Cenário Base Case sem vegetação. Apresenta 9 quadras com $\mathbf{2 4 m}$ de altura no formato perimetral e sem vegetação

As simulações foram feitas para o dia 19 de dezembro às 14h. A Figura 99 mostra o resultado da simulação, em que a temperatura do ar na área asfaltada da rua ficou em torno de $28^{\circ} \mathrm{C}$ e a parte interna da quadra em concreto chegou a $26.8^{\circ} \mathrm{C}$. A temperatura superficial atingiu $59^{\circ} \mathrm{C}$ nas vias e nos espaços entre os edifícios. A temperatura superficial de $33.6^{\circ} \mathrm{C}$ ocorreu nas áreas sombreadas pelos edifícios. 


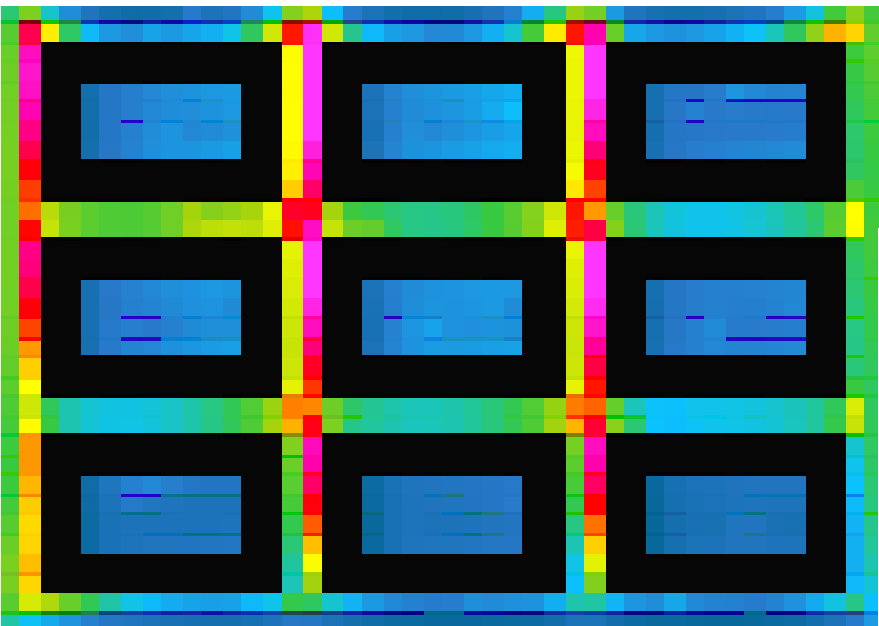

Temperatura do Ar

Figura 99: Simulação Cenário Base Case - Temperatura do Ar às 14h.

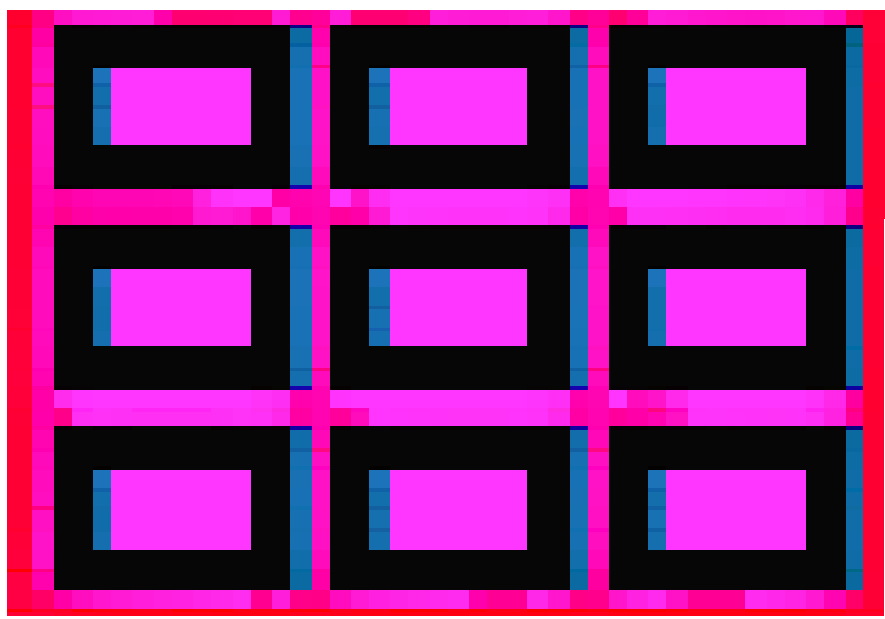

Temperatura Superficial

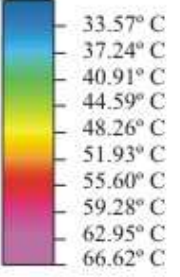

Figura 100: Simulação Cenário Base Case - Temperatura Superficial às 14h.

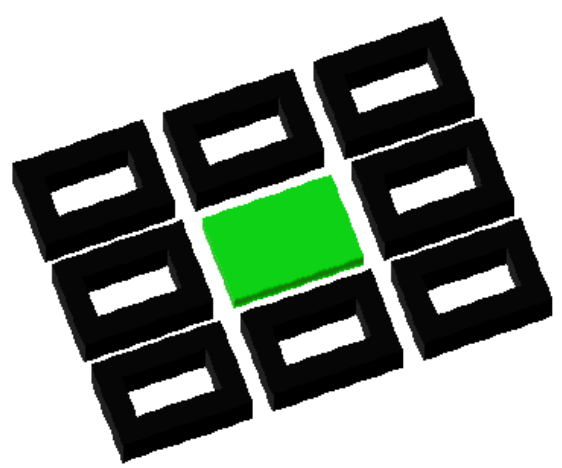

Figura 101: Modelo 3D do Cenário 4 com vegetação na quadra central. Formado por 8 quadras com edifícios com $24 \mathrm{~m}$ de altura e 1 quadra com árvores T4 (LAI=10). 
Os resultados do Cenário 4 para temperatura do ar nas vias públicas estão entre $27.5^{\circ} \mathrm{C}$ e $28^{\circ} \mathrm{C}$. Os valores nas área do parque central estão ligeiramente menores do que no Base Case. A temperatura superficial nas áreas vegetadas ficou em torno de $31^{\circ} \mathrm{C}$, enquanto que nas áreas sombreadas pelos edifícios foi de $34^{\circ} \mathrm{C}$ e, nas vias, $56^{\circ} \mathrm{C}$.

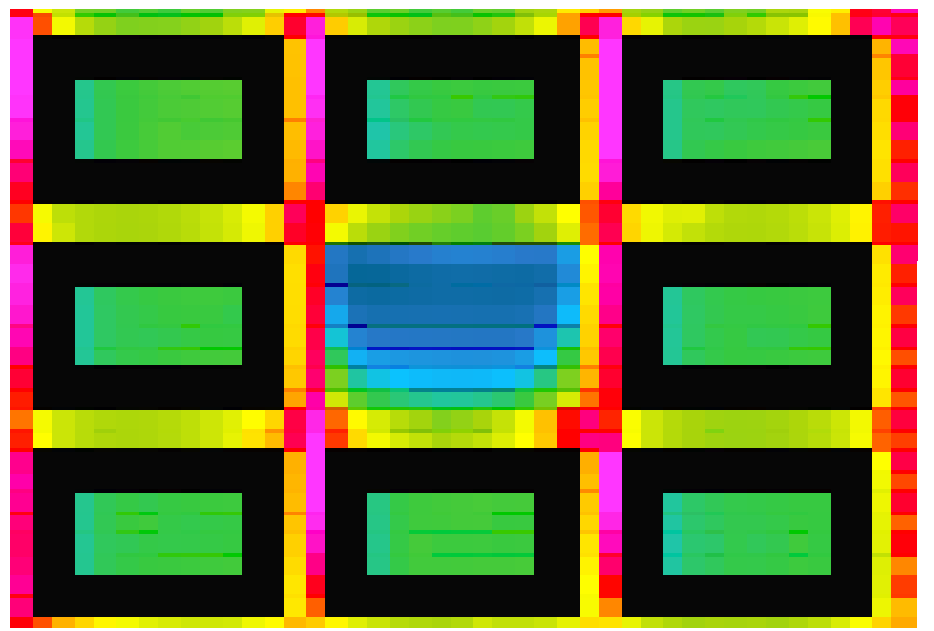

\section{Temperatura do $\mathrm{Ar}$}

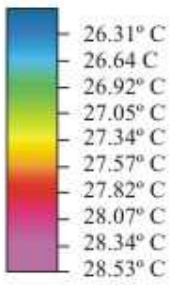

Figura 102: Simulação Cenário 4 - Temperatura do ar às 14h.

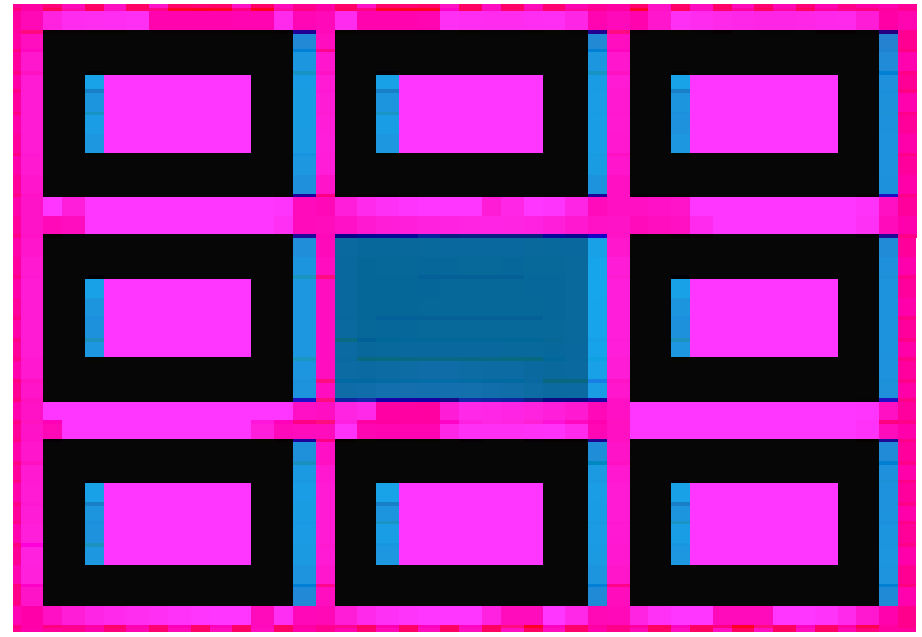

Temperatura Superficial

Figura 103: Simulação Cenário 4 - Temperatura Superficial às 14h. 


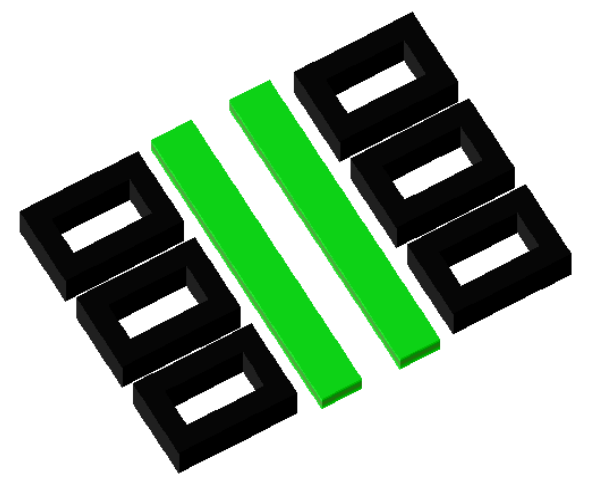

Figura 104: Modelo 3D do Cenário 5 com vegetação de forma linear. Formado por 6 quadras com edifícios de 24m de altura, 3 quadra com árvores T4 (LAI=10) e espelho d'água na parte central.

Os resultados do Cenário 5 para temperatura do ar estão entre $25.3^{\circ} \mathrm{C}$ e $27.8^{\circ} \mathrm{C}$. Além de apresentar os melhores resultados de temperatura, com esta configuração também se consegue a melhor distribuição do efeito climático das áreas verdes. O vento que atravessa as árvores ameniza as temperaturas das ruas atrás do parque linear. A combinação do sombreamento das árvores com a densidade foliar das copas favorece a redução em $1^{\circ} \mathrm{C}$ em relação às áreas pavimentadas do Base Case.

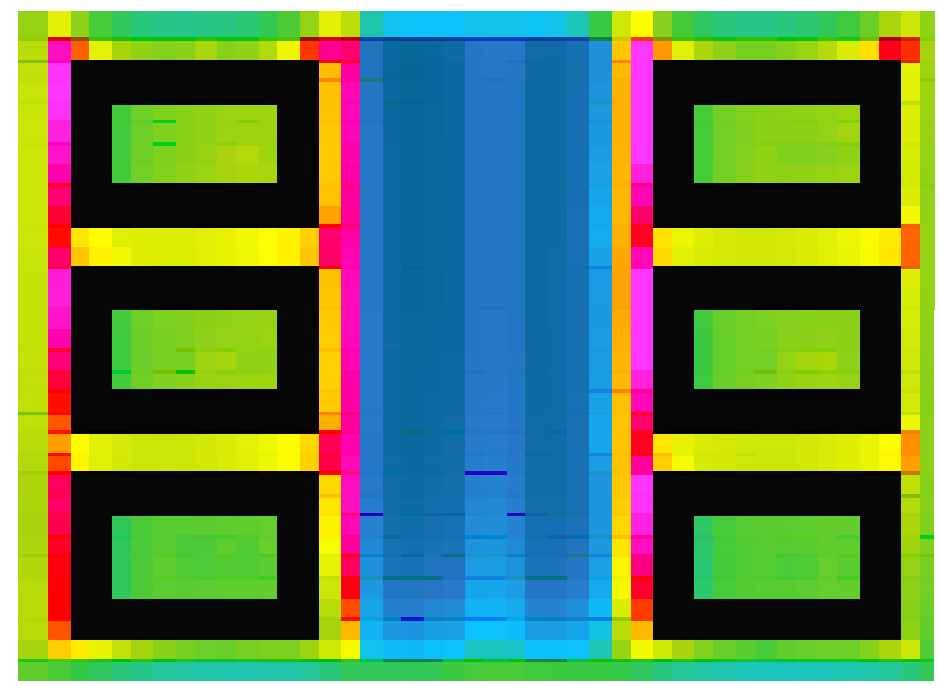

Temperatura do $\mathrm{Ar}$

Figura 105: Simulação Cenário 5 - Temperatura do Ar às $14 \mathrm{~h}$. 




Temperatura Superficial

Figura 106: Simulação Cenário 5 - Temperatura Superficial às 14h.

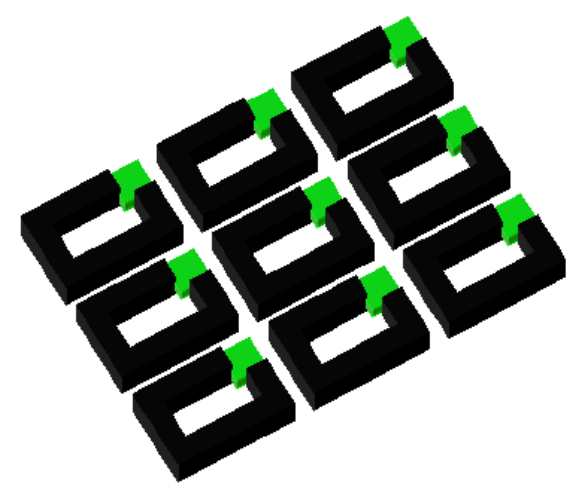

Figura 107: Modelo 3D do Cenário 6 com pequenos parques. Formado por 9 quadras com edifícios de $24 \mathrm{~m}$ de altura e 9 pequenos parques com árvores $\mathrm{T} 4$ (LAI=10).

Os resultados do Cenário 6 para temperatura do ar estão entre $26.3^{\circ} \mathrm{C}$ e $28.52^{\circ} \mathrm{C}$. A composição espacial em pequenos parques permite uma melhor distribuição do efeito climático das áreas verdes e mostra vantagens em relação ao desenho do parque central. As diferenças das temperaturas acontecem nos limites do parque e esse cenário apresenta temperaturas menores do que no Base Case. 


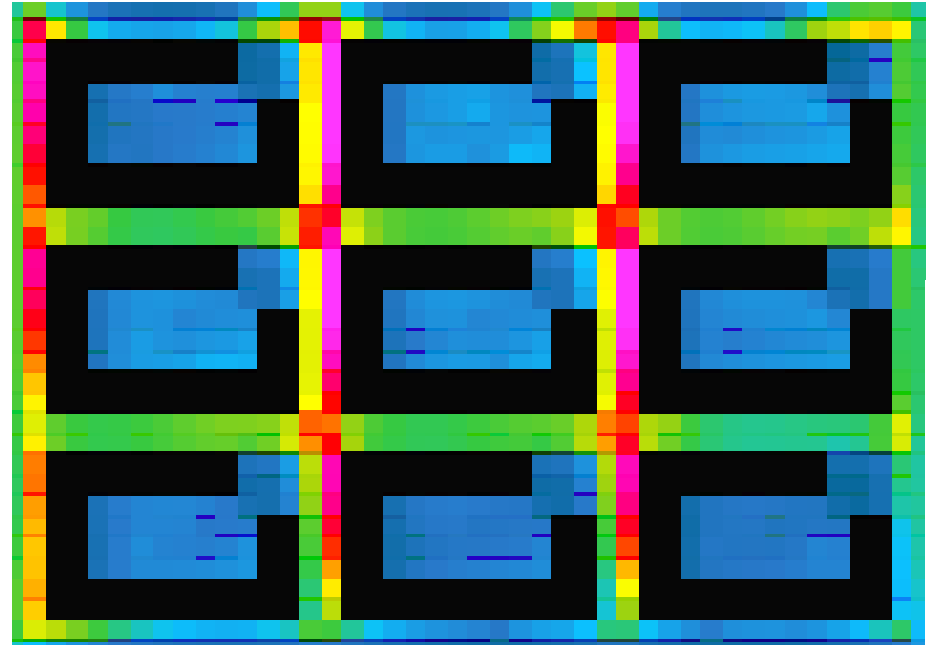

Temperatura do $\mathrm{Ar}$

Figura 108: Simulação Cenário 6 - Temperatura do Ar às 14h.

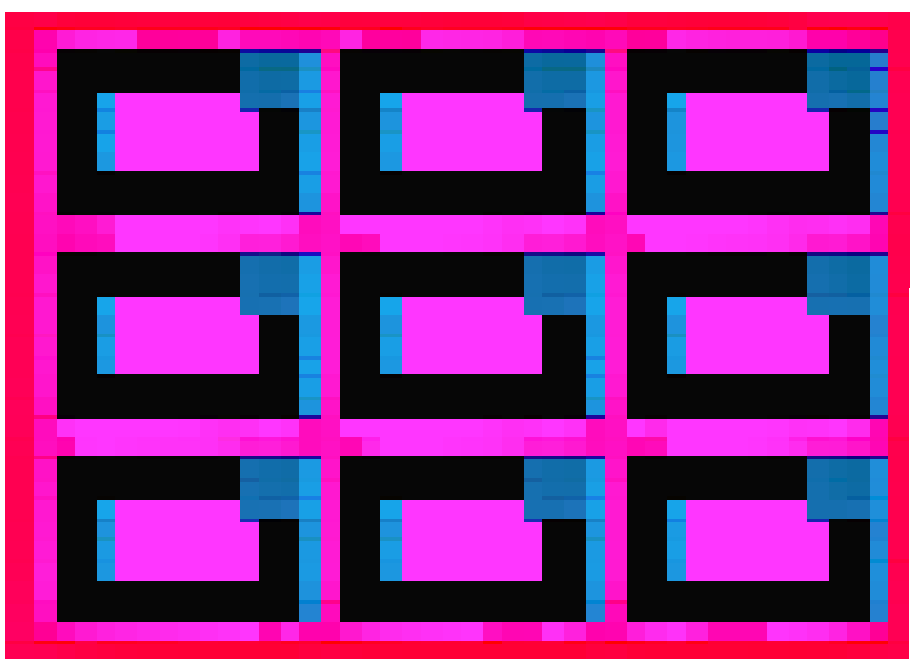

Temperatura Superficial

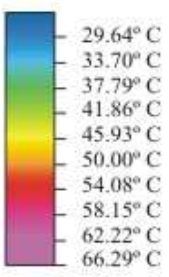

Figura 109: Simulação Cenário 6 - Temperatura Superficial às 14h.

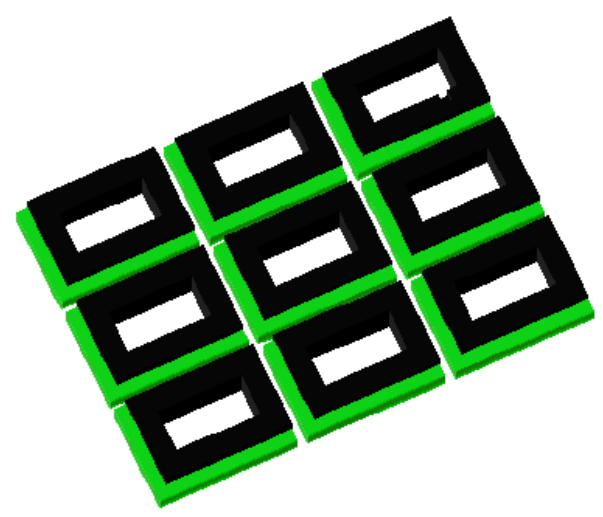

Figura 110: Modelo 3D do Cenário 7 com arborização nas vias. Formado por 9 quadras com edifícios de $24 \mathrm{~m}$ de altura e árvores $\mathrm{T} 4(\mathrm{LAI}=10)$ nas calçadas. 
No Cenário 7, a presença de vegetação nas calçadas reduziu a temperatura do ar em até $2.5^{\circ} \mathrm{C}$ em relação aos resultados obtidos no Base Case. A temperatura superficial nas vias com vegetação ficou entre $30^{\circ} \mathrm{C}$ e $34^{\circ} \mathrm{C}$; no entanto, nas ruas sem árvores a temperatura chegou a $55^{\circ} \mathrm{C}$.

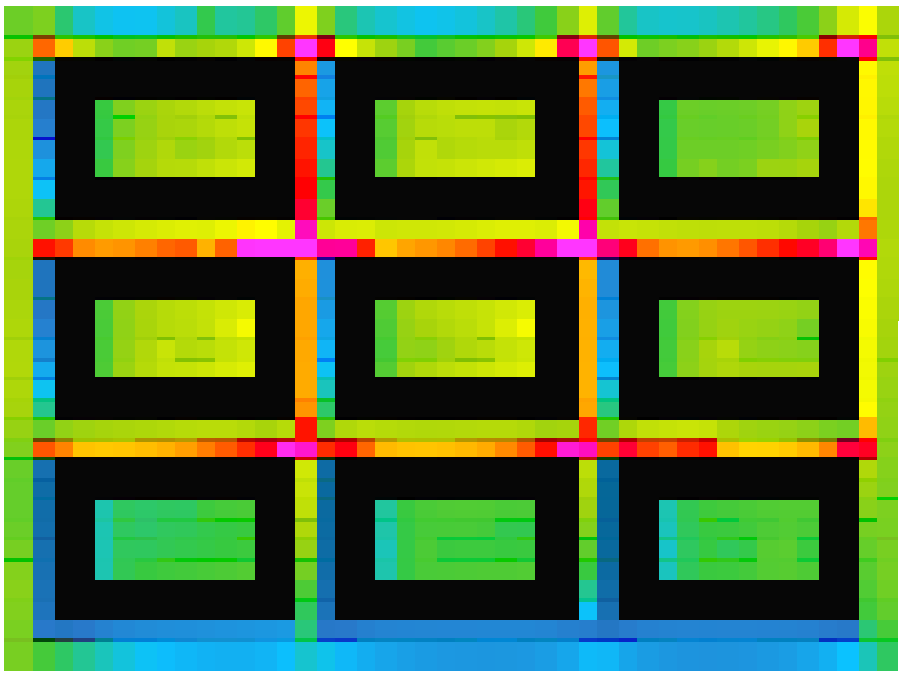

Temperatura do Ar

Figura 111: Simulação Cenário 7 - Temperatura do Ar às 14h.

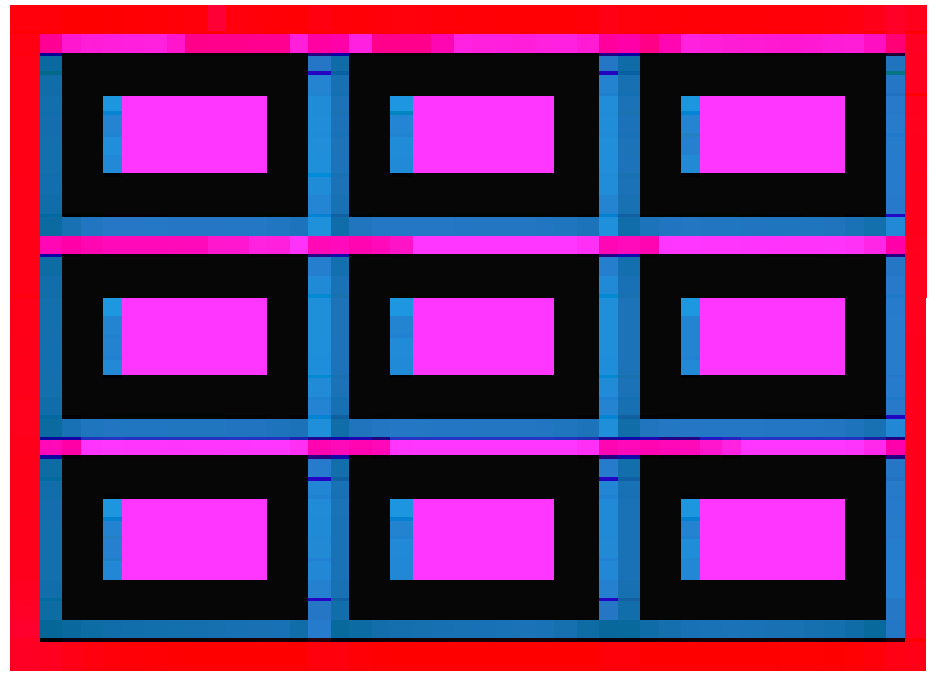

Temperatura Superficial

Figura 112: Simulação Cenário 7 - Temperatura Superficial às 14h. 


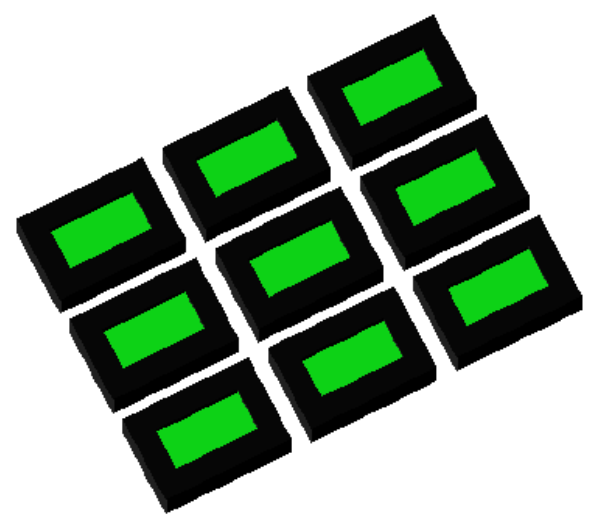

Figura 113: Modelo 3D do Cenário 8 com arborização nas vias. Formado por 9 Quadras com edifícios de 24m de altura e árvores T4 (LAI=10) no miolo de quadra.

O Cenário 8 simulou o efeito da vegetação no interior da quadra, que nos cenários anteriores era uma superfície impermeabilizada em concreto. No Base Case, a temperatura do ar ficou em torno de $27^{\circ} \mathrm{C}$ e, com a presença das áreas verdes, os valores foram reduzidos para $25.7^{\circ} \mathrm{C}$.

A temperatura superficial nas ruas manteve-se em $55^{\circ} \mathrm{C}$; no interior das quadras, chegou-se a $25.7^{\circ} \mathrm{C}$ e, nas áreas sombreadas, $34.5^{\circ} \mathrm{C}$.

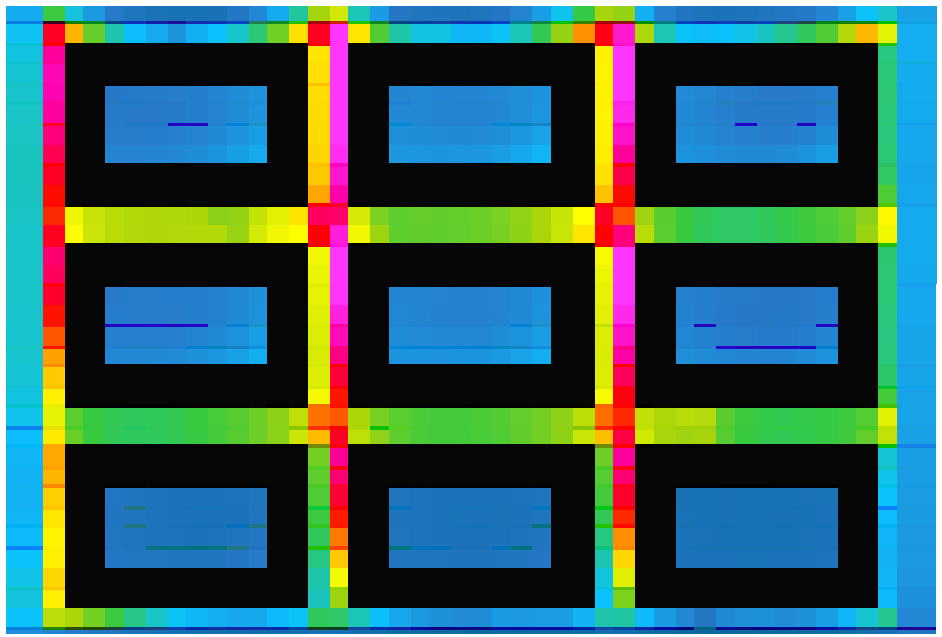

Temperatura do $\mathrm{Ar}$

Figura 114: Simulação Cenário 8 - Temperatura do Ar às 14h. 


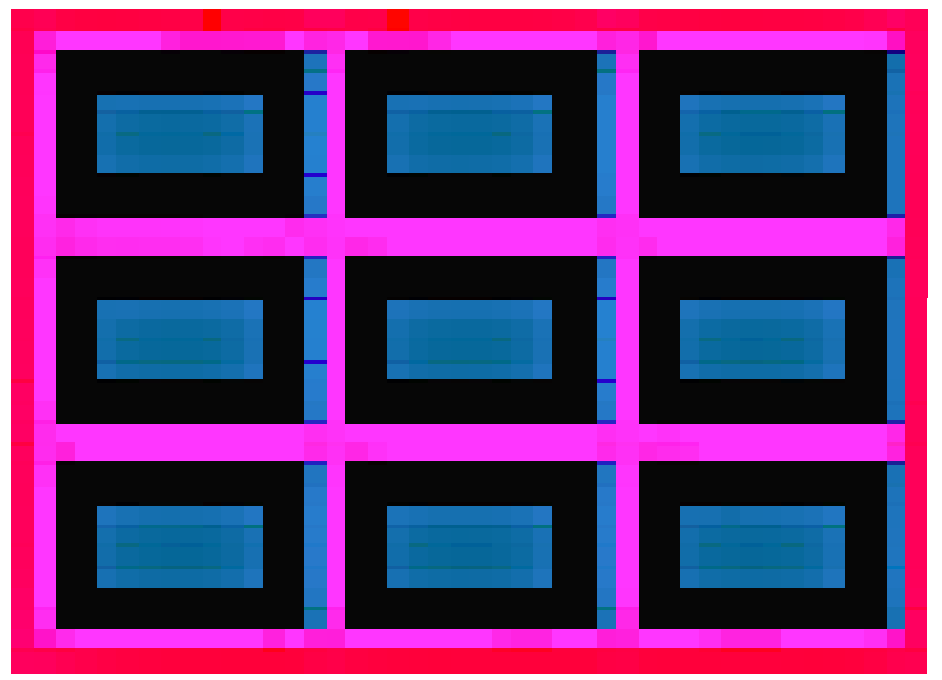

Temperatura Superficial

Figura 115: Simulação Cenário 8 - Temperatura Superficial às 14h.

\subsection{SIMULAÇÃO PARA A ÁREA DA LUZ}

A partir das simulações paramétricas, foi escolhida uma área real no Bairro Luz formada por oito quadras e localizada em frente à Estação da Luz, no Centro de São Paulo. A Figura 116 mostra a situação existente com duas praças pouco arborizadas, uma em frente à Estação da Luz e a outra localizada na avenida Rio Branco. Na proposta, ambas as praças receberam áreas verdes com árvores T4 $(\mathrm{LAI}=10)$. Além disso, foi inserida vegetação nos vazios existentes no interior das quadras (Figura 117).

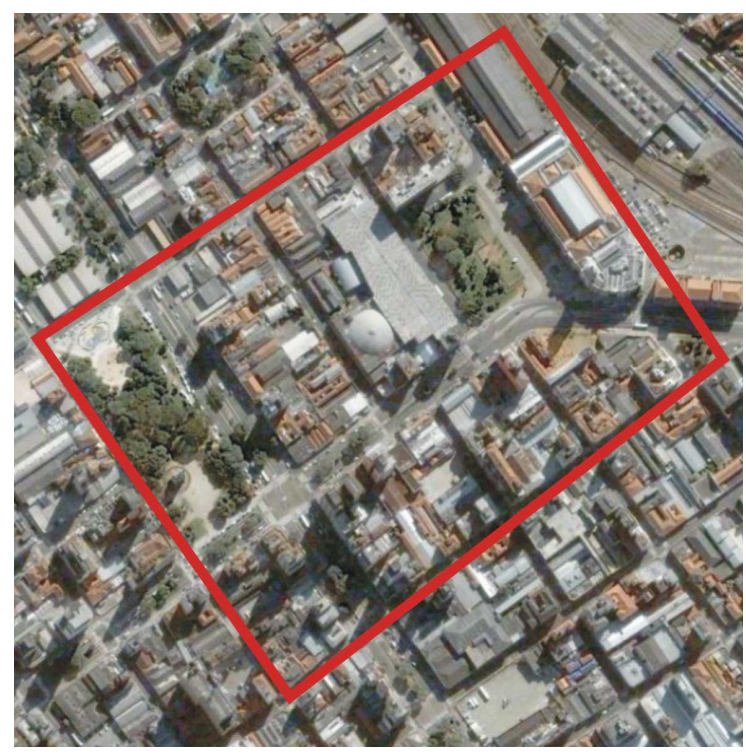

Figura 116: Área definida para simulação no ENVI-met.

Fonte: Google Earth. Disponível em: < http://earth.google.com/ >. Acesso em janeiro de 2009. 


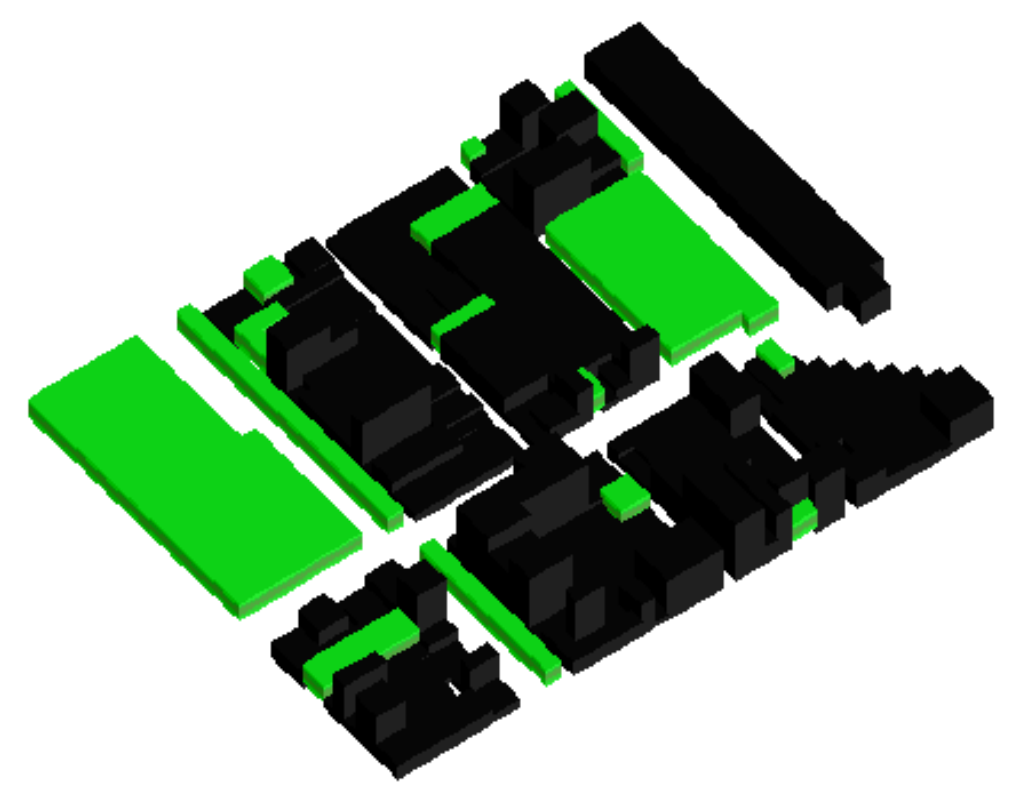

Figura 117: Proposta de inserção da vegetação na área da Luz.

A Figura 118 apresenta os resultados simulados pelo ENVI-met, indicando que nas áreas vegetadas das praças a temperatura do ar ficou em torno dos $25.5^{\circ} \mathrm{C}$ e, nos vazios arborizados, $25.7^{\circ} \mathrm{C}$. Nas ruas próximas às áreas vegetadas a temperatura do ar é de $27^{\circ} \mathrm{C}$ e, nas vias públicas sem árvores, existe um pequeno aumento para $27.8^{\circ} \mathrm{C}$

A Figura 119 mostra significativas diferenças nas temperaturas superficiais entre as áreas com e sem vegetação. Nas praças arborizadas os valores variam entre $23^{\circ} \mathrm{C}$ e $27^{\circ} \mathrm{C}$, enquanto nas ruas asfaltadas a temperatura chega a $50^{\circ} \mathrm{C}$.

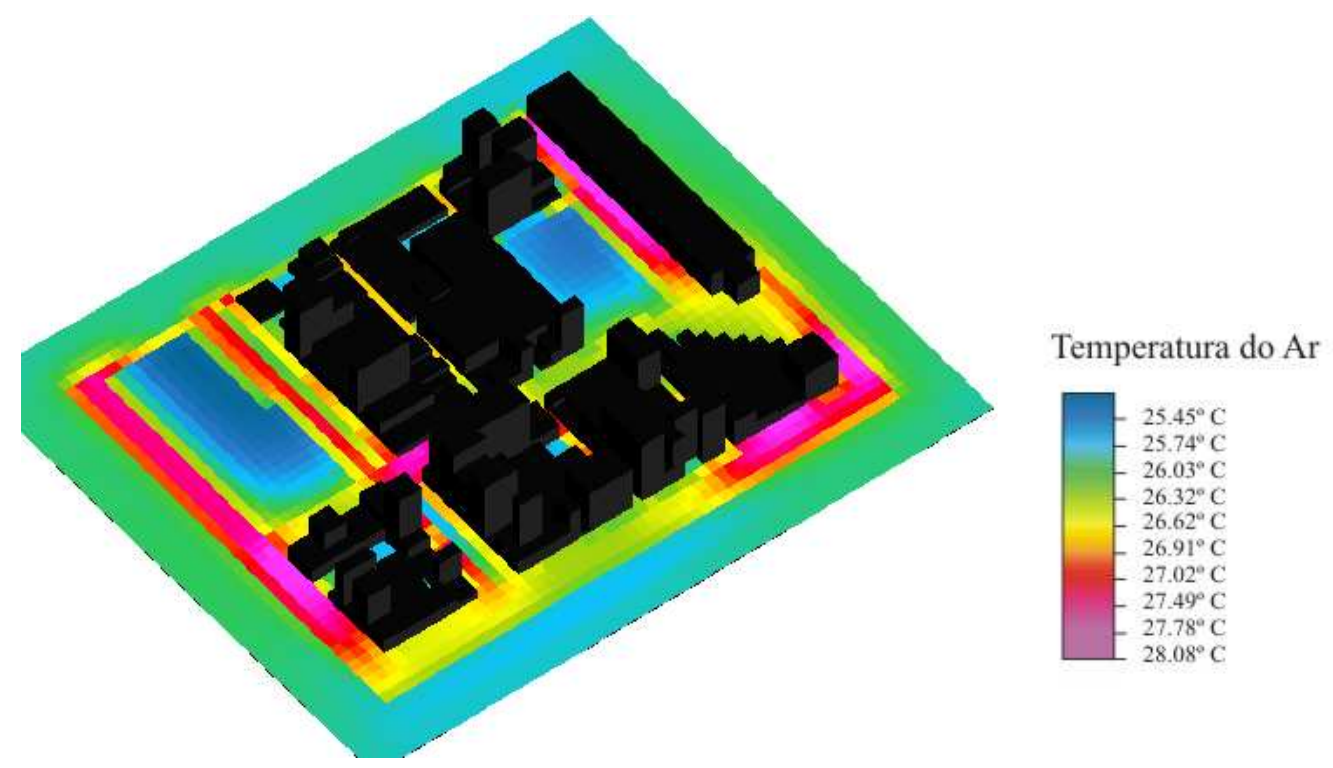

Figura 118: Simulação Proposta Área da Luz - Temperatura do Ar às 14h. 
PAULA SHINZATO

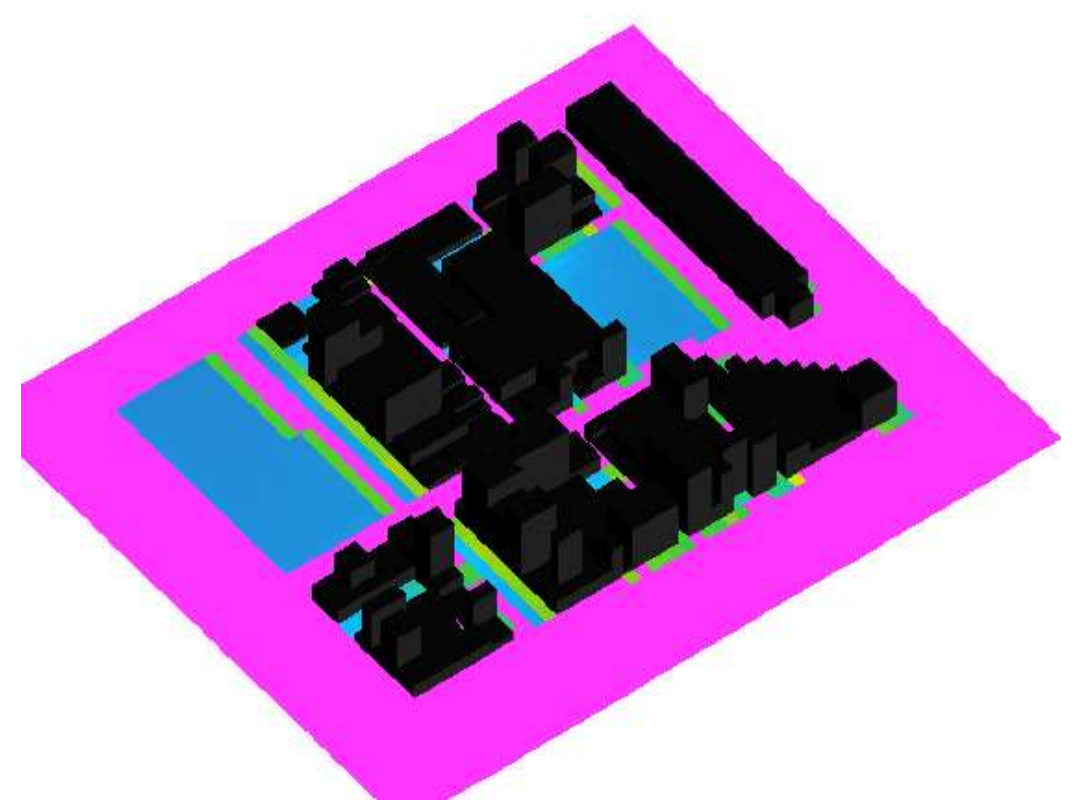

Temperatura Superficial

Figura 119: Simulação Proposta Área da Luz - Temperatura Superficial às 14h. 


\section{ANÁLISE DOS RESULTADOS, CONSIDERAÇÕES FINAIS E CONCLUSÕES}

\subsection{ANÁLISE DOS RESULTADOS}

Em função das respostas obtidas a partir dos cenários simulados no ENVI-met observam-se os seguintes resultados:

\subsubsection{CENÁRIOS PEQUENA ESCALA (CANYON)}

- Nas simulações de temperatura do ar, todos os cenários comportam-se da mesma forma e apresentam valores iguais a $26^{\circ} \mathrm{C}$.

- O uso da grama não tem o mesmo efeito se comparado com as árvores. A diferença está na densidade foliar que contribui nos processos de evapotranspiração e sombreamento.

- Nas simulações de temperatura superficial, conforme esperado, as gramíneas se aquecem menos do que o asfalto, com diferenças de até $6^{\circ} \mathrm{C}$. Embaixo das árvores, a diferença da temperatura superficial no solo aumenta para $17^{\circ} \mathrm{C}$ em espécies $\mathrm{T} 3$ $(\mathrm{LAI}=3)$ e $20^{\circ} \mathrm{C}$ para as espécies $\mathrm{T} 4(\mathrm{LAI}=10)$.

- As comparações anteriores também ajudam caracterizar o efeito das árvores com diferentes valores de LAI. As espécies com copas mais densas (LAI=10) barram a passagem da radiação solar direta e resultam em temperaturas superficiais do solo abaixo da árvore menores em até $3^{\circ} \mathrm{C}$ em relação às copas pouco densas $(\mathrm{LAI}=3)$.

\subsubsection{CENÁRIOS MÉdIA ESCALA (NOVE QUADRAS)}

- Os valores da temperatura do ar apresentam poucas diferenças, comparando-se os cenários com as árvores densas e o Base Case (sem vegetação). As áreas com asfalto têm uma média de temperatura do ar de $27.5^{\circ} \mathrm{C}$ às $14 \mathrm{~h}$, já os espaços pavimentadas em concreto têm valores em torno de $26.8^{\circ} \mathrm{C}$. As áreas verdes reduzem a temperatura do ar em até $1.5^{\circ} \mathrm{C}$ em relação às áreas com asfalto.

- As temperaturas do ar mais baixas ocorreram nas áreas verdes do Cenário 5, em que o desenho linear do parque favoreceu a canalização dos ventos e a retirada do calor acumulado. A temperatura do ar ficou em torno dos $25.3^{\circ} \mathrm{C}$. 
- Em relação à temperatura superficial os casos com árvores também apresentam valores menores que o Base Case, pois evitam o aquecimento das superfícies do solo pela radiação solar direta. Em média, as áreas arborizadas apresentam temperaturas entre $28.5^{\circ} \mathrm{C}$ e $31^{\circ} \mathrm{C}$. Nas ruas, a temperatura superficial variou de $55^{\circ} \mathrm{C}$ a $58^{\circ} \mathrm{C}$, uma diferença de até $29^{\circ} \mathrm{C}$ se comparado com as áreas verdes arborizadas.

- O efeito das árvores com solo coberto em terra apresentou temperaturas superficiais mais baixas que o sombreamento dos edifícios, com diferenças de até $4^{\circ} \mathrm{C}$.

\subsection{3 ÁREA DA LUZ}

- Conforme observado nos estudos paramétricos, o valor de temperatura do ar para as ruas ficou em torno dos $27^{\circ} \mathrm{C}$ e, nas áreas verdes, $25.6^{\circ} \mathrm{C}$.

- O efeito das árvores com solo coberto por terra apresentou na temperatura superficial valores significativos, chegando a reduzir $23^{\circ} \mathrm{C}$ em relação à temperatura nas ruas.

- Por outro lado, o efeito da vegetação é local e não ocorre uma influência significativa muito além dos limites das áreas verdes.

\subsection{CONSIDERAÇÕES FINAIS}

Segundo Givoni (1991 apud Duarte 2000), a influência de parques urbanos e espaços abertos no clima urbano se estendem somente a uma curta distância nos arredores densamente construídos. Santamouris (2001) avançou no sentido de realizar medições da temperatura do ar nas áreas internas e externas a um parque na cidade de Atenas, Grécia. O resultado indicou que a variação das temperaturas do ar no interior do parque foi de no máximo $1.5^{\circ} \mathrm{C}$ e a diferença entre o parque e o entorno durante o dia foi de aproximadamente $3^{\circ} \mathrm{C}$.

Bruse (2004) estudou o efeito de um parque em Melborne, Austrália, utilizando o programa ENVI-met e demonstrou que as temperaturas do ar entre o parque e a rua foi de no máximo $2^{\circ} \mathrm{C}$. Agora este trabalho acrescenta novos dados com simulações realizadas para as condições microclimáticas da cidade de São Paulo e indicou uma diferença média de $1.5^{\circ} \mathrm{C}$ entre as temperaturas do ar nas áreas verdes arborizadas e as 
ruas adjacentes, além de quantificar as diferenças nas temperatura superficiais embaixo da copa e nas vias, com diferenças de $23^{\circ} \mathrm{C}$, em média.

\subsection{CONCLUSÃO}

A pesquisa tinha como objetivo quantificar a intensidade e a distribuição espacial dos efeitos microclimáticos da vegetação. Por meio das medições de campo e das simulações realizadas pelo programa computacional ENVI-met pode-se quantificar a importância da vegetação nos aspectos climáticos.

Conforme mencionado no Capítulo 2, a vegetação permite o resfriamento e o aumento da umidade do ar pelo processo de evapotranspiração. Isso foi observado nos modelos paramétricos que indicaram temperaturas mais baixas nas áreas verdes, porém, a intensidade é pequena, sendo no máximo $1.5^{\circ} \mathrm{C}$.

Em relação à intensidade do efeito da vegetação, o sombreamento pelas árvores com LAI 10 mostrou resultados significativos com redução de temperaturas superficiais do solo, com cobertura em terra, de até $29^{\circ} \mathrm{C}$ nas áreas verdes e de $4^{\circ} \mathrm{C}$ para as áreas sombreada por edifícios.

Esse resultado indica que o uso das árvores é uma estratégia para amenizar o efeito de ilha de calor nas metrópoles, pois evita o aquecimento de materiais como asfalto e concreto e a liberação do calor acumulado durante a noite. A densidade da copa é o principal fator para a qualidade do sombreamento.

No entanto, a abrangência dos efeitos microclimáticos da vegetação urbana é limitada e, segundo as medições de campo, a influência das árvores é sentida embaixo das copas e, no máximo, nas áreas de projeção das sombras. Nesse sentido, pensando no conforto do pedestre, é preferível distribuir a vegetação em pequenos grupos do que implantar um único e grande parque.

As diferentes configurações espaciais para distribuição da vegetação (linear, pequenos e grandes agrupamentos) mostraram que o desenho também é importante para maximizar o efeito da vegetação, pois os modelos no formato linear e a arborização nas calçadas obtiveram os melhores resultados na temperatura do ar uma vez que facilitaram a passagem dos ventos. 


\section{REFERÊNCIA S BIBLIOGRÁFICAS}

AKBARI, H. Energy Saving Potentials and Air Quality Benefits of Urban Heat Island Mitigation. Lawrence Berkeley National Laboratory. 2005. Disponível em: < http://www.osti.gov/bridge/servlets/purl/860475-UlHWIq/860475.PDF >. Acesso em março de 2009.

AKBARI, H. Shade Trees Reduce building energy use and CO2 emission from power plants. Heat Island Group, 2001. Disponível em: <http://eetd.lbl.gov/HeatIsland/PUBS/PUBSLIST.html > Acesso em: 21 março de 2006.

AKBARI, H.et. al. Paiting the town white and green. Heat Island Group, 1997. Disponível em: < http://eetd.lbl.gov/HeatIsland/PUBS/PAINTING/> Acesso em: 21 março de 2006.

ALI- TOUDERT, F. Dependence of outdoor thermal comfort on street design in hot and dry climate. Berichte des Meteorologischen Institutes der Universität Freiburg n. 15, 2005.

ALVAREZ DOMINGUEZ, S. et al. Control Climático em Espacios Abiertos. El Proyecto EXPO'92. Sevilha: CIEMAT, 1992.

ALUCCI, M.P.; MONTEIRO, L. M. Climate and thermal Stress in outdoor spaces. In: Passive Low Energy Architecture, 21, Eindhoven, 2004. Proceedings. Built environments and environmental buildings. Eindhoven: PLEA, 2004 (CD-ROM).

ALUCCI, M. P. Coberturas têxteis; determinação de características termo-luminosas. São Paulo: LABAUT, CNPq, 2005.

ASSIS, E. S. Mecanismos de desenho urbano apropriado à atenuação da ilha de calor urbana: análise de desempenho de áreas verdes em clima tropical. Rio de Janeiro, 1990. Tese (Mestrado em Arquitetura) Faculdade de Arquitetura e Urbanismo, Universidade Federal do Rio de Janeiro, 1990.

ASSIS, E. S. Impacto da forma urbana na mudança climática: método para previsão do comportamento térmico e melhoria do desempenho do ambiente urbano. São Paulo, 2000. Tese (Doutorado em Arquitetura) Faculdade de Arquitetura e Urbanismo, Universidade de São Paulo, 2000.

ASSIS, E. S. Abordagem do Clima Urbano e Aplicações no Planejamento: Reflexões sobre uma trajetória. In: VIII Encontro Nacional sobre Conforto no Ambiente Construído, 2005, Maceió, Alagoas. Anais. Maceió, Alagoas: ENCAC -ELACAC, 2005. 
BAKER, N; RATTI, C. Simplified Urban Climate Models from Medium-Scale Morphological Parameters. In: Passive Low Energy Architecture, 17, Proceedings. International Passive and Low Energy Architecture Conference. Cambridge: PLEA, 2000. Proceedings.

BARTHOLOMEI, C. L. B. Estudo da Atenuação da Radiação Solar incidente por diferentes espécies arbóreas. 1998. Tese (Mestrado em Engenharia Civil). Universidade Estadual de Campinas, Fundação de Amparo à Pesquisa do Estado de São Paulo, 1998.

BARTHOLOMEI, C. L. B. Influência da vegetação no conforto térmico urbano e no ambiente construído. 2003. Tese (Doutorado em Engenharia Civil). Universidade Estadual de Campinas, Fundação de Amparo à Pesquisa do Estado de São Paulo, 2003.

BERTOL et al. Aspectos financeiros relacionados às perdas de nutrientes por erosão hídrica em diferentes sistemas de manejo do solo.Revista Brasileira de Ciência do Solo, v. 31, n.1, 2007. Disponível em: < http://www.scielo.br/scielo.php?pid=S0100-

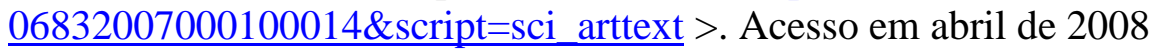

BORCKE, C. V. Sustainable Urban Design: An Environmental Approach. Spon Press.2006.

BRANDÃO, Rafael Silva. Acesso ao sol e à luz natural: Avaliação do impacto de novas edificações no desempenho térmico, luminoso e energético no seu entorno. 2004. Dissertação (Mestrado em Arquitetura) Faculdade de Arquitetura e Urbanismo, Universidade de São Paulo, 2004.

BRUSE, M.Simulating the Effects of Urban Environmental on Microclimate with a Three-Dimensional Numerical Model. In: Climate and Environmental Change, Conference Meeting of the Commission on climatology, Evora, 1998.

BRUSE M. Modelling and Strategies for improved urban climates. In: Proceedings International Conference on Urban Climatology and International Congress of Biometeorology, Sydney, 1999.

BRUSE, M. ENVI-met implementation of the Jacobs A-gs. Model to calculate the stomata conductance. Bochum, 2004. Disponível no site: <http://www.geographie.ruhruni-bochum.de/agklima/envimet/> Acesso em: março de 2006.

BRUSE, M. ENVI-met 3.0 Manual. 2003. Disponível em:: < http://envi-met.com > Acesso em: agosto de 2006.

CAMPBELL, G. S. An Introduction to Environmental Biophysics, Heidleberg Science Library, Springer-Verlag, New York, 1977, p.159.

CARTER, J. Food and Agriculture Organization - FAO, The potencial of Urbana Forestry in developing countries, 1995. Disponível em: 
〈http://www.fao.org/docrep/005/t1680e/T1680E00.htm\#TOC >. Acesso em maio de 2008.

CAVALHO, C. São Paulo tem 500 pontos que alagam, temperatura subiu e ventos mudaram. Jornal O Globo Online, 2007. Disponível em: <http://oglobo.globo.com/sp/mat/2007/03/15/294943263.asp>. Acesso abril de 2007.

CHATZIDIMITRIOU, A.; CHRISSOMALLIDOU, N. YANNAS, S. In: International Passive and Low Energy Architecture Conference, 22, Beirut, 2005. Proceedings. 2005. Beirut: PLEA, 2005.

CITY OF DAVIS. Community Forest Management Plan, 2002. Diponível em: < http://cityofdavis.org/pgs/trees/pdfs/CFMP-Final-Sept2002-ch1.pdf >. Acesso em março de 2008.

CORBELLA, O.; YANNAS, S. Em busca de uma arquitetura sustentável para os trópicos. Conforto Ambiental. Editora Revan Rio de Janeiro, 2003.

CREMONESI, J. F. Ruído Urbano. Dissertação (Mestrado em Arquitetura e Urbanismo) Faculdade de Arquitetura e Urbanismo, Universidade de São Paulo, São Paulo, 1984.

DEARDORFF, J.W. Efficient Prediction of Ground Surface Temperature and Moisture with a Inclusion of a Layer of Vegetation. Journal of Geophysical Research, Colorado, v.83, n.C4, 1978.

DIMOUNDI, A; NIKOLOPOULOU, M. Vegetation in the Urban Environment: Microclimatic Analysis and Benefits. Energy and Buildings, vol.35, n.1, 2003.

DOUGLAS, I. Urban greenspace and mental heath. UK MAB Urban Forum. Manchester, 2005.

DUARTE, D. LABAUT - Laboratório de Conforto Ambiental e Eficiência Energética. Pós. Revista do Programa de Pós-Graduação em Arquitetura e Urbanismo da FAU, São Paulo, n. 15, junho 2004, p. 132-141.

DUARTE, D. Padrões de Ocupação do solo e microclimas urbanos na região de clima tropical continental. 2000. Tese (Doutorado em Arquitetura e Urbanismo). Faculdade de Arquitetura e Urbanismo, Universidade de São Paulo, São Paulo, 2000.

DUARTE, D.; SERRA, G. Urban Occupation Patterns and Microclimates. An index for decision-making. In: SB 2002 - SUSTAINABLE BUIDING, Oslo, 2002. Sustainable Building. The Challenge. The Knowledge. The Solutions. Oslo: The Norwegian EcoBuild Program, 2002.

DUARTE, D., SERRA, G. Padrões de ocupação do solo e microclimas urbanos na região de clima tropical continental. Correlações e proposta de um indicador. Ambiente Construído, Porto Alegre, v. 3, n. 2, p. 7-20, 2003. 
DUARTE, D.; SOUZA, T. Urban Occupation Patterns and Microclimates in Sao Paulo - Brazil. In: SB 2005 - SUSTAINABLE BUIDING, 2005, Tokyo. The 2005 World Sustainable Building Conference. 2005.

DUARTE, D., GONÇALVES, J. Environment and Urbanization: Microclimatic Contrasts at a Brownfield Site in São Paulo, Brazil. In: PLEA - Passive Low Energy Architecture, 23, Geneva, 2006. Proceedings. Geneva: PLEA, 2006 (no prelo).

ENVIRONMENTAL PROTECTION AGENCY- EPA. Protecting Water Quality from Urban Runoff. 2003. Disponível em: < http://www.eustis.org/npdes/Urbanfacts.pdf $>$ Acesso em outubro de 2007.

FANGER, P.O. Thermal comfort, analysis and application in environmental engineering. New York: McGraw Hill, 1972.

FORMAN, R. T. T.; GODRON, M.. Landscape Ecology. John Wiley, New York, 1986.

FAVIS-MORTLOCK, D.T.; QUINTON, J.N.; DICKINSON, W.T. The GCTE validation of soil erosion models for global change studies. Journal of Soil and Water Conservation, v.55, n.5, 1996, p.397-403.

GATTI, M. Patrimônio da cidade passa a receber tratamento especial. Revista Acim, 469. ed , setembro, 2007.Disponível em: < http://funverde.wordpress.com/2007/09/15/patrimonio-da-cidade-passa-a-recebertratamento-especial/ > .Acesso em março de 2008.

GEIGER, R. 1965. The climate near the ground. Harvard University Press, USA.

GILBERTSON, P.; BRADSHAW, A.D. The survival of newly planted trees in inner cities. Arboricultural Journal, v.14, 1990, p.287-309.

GIVONI, B. Climate Considerations in Urban and Building Design. New York: John Wiley \& Sons, 1998.

GIVONI, B. Impact of Planted Areas on Urban Environmental Quality- A review. Atmosferic Environment, vol. 25, n.3, 1991, p.289-299.

GONÇALVES, J. C. S. A sustentabilidade de edifícios altos: uma nova geração de edifícios altos e sua inserção urbana. 2003. Tese (Doutorado em Arquitetura e Urbanismo) Faculdade de Arquitetura e Urbanismo, Universidade de São Paulo, São Paulo, 2003.

GUERRA MACHO, J. J. et al. Control Climático em Espacios Abiertos. Evaluacíon del Proyecto EXPO'92. Sevilha: CIEMAT, 1994. 
GRAHN, P. Green structures - The importance for health of nature areas and parks. European Regional Planning, n. 56, 1994, p. 89-112.

GREATER LONDON AUTHORITY. Summary of Social Trends 2007 - From the Office for National Statistics publication. 2007. Disponível em:

$<$ www.london.gov.uk/gla/publications/factsandfigures/dmag-briefing-2007-10.pdf $>$. Acesso em fevereiro de 2008.

GREEN, E. P; CLARK, C.D. Assessing Mangrove Leaf Area Index and Canopy Closure. In: Alasdair, J. Edwards (Ed.), Remote Sensing Handbook for Tropical Coastal Manegement Sourcebooks 3. Part 5. Quantitative Measurement of Ecological Parameteres and Marine Resource Assessment, CSI, UNESCO, 2000.

GRIMMOND, C.S.B; OKE, T. Variability of Evapotranspiration Rates in Urban Areas. In: Passive Low Energy Architecture, 17, Proceedings. International Passive and Low Energy Architecture Conference. Cambridge: PLEA, 2000. Proceedings.

GRIMMOUND, C. S. B., OKE, T.R. Turbulent heat fluxes in urban areas: Observations and Local-Scale Urban Meteorological Parameterization Scheme (LUMPS). Journal of Applied Meteorology.,vol. 41, p.792-810, 2002.

GROLEAU, D., MIGUET, F. Solène et la simulation des éclairements directs et diffus des projets architecturaux et urbains. IBPSA France '98. Sophia Antipolis, 1998, p.6165 .

JACOBS, C.M.J. Direct Impact of Atmospheric $\mathrm{CO}_{2}$ Enrichment on Regional Transpiration. Tese.Wageningen Agricultural University, Netherland, 1994.

JANSSON, C. URBAN MICROCLIMATE AND SURFACE HYDROMETEOROLOGICAL PROCESSES. Tese (Doutorado em Arquitetura), KTH Architecture and Built Environment, Estocolmo, 2006.

JANSSON, P.E.; MOON, D.S. A coupled model of water, heat and mass transfer using object orientation to improve flexibility and functionality. Environmental Modelling \& Software,v. 16, 2001, p. 37-46.

AVIS, P.G; Stomata Control of Transpiration: Scaling Up from Pore to Paddock. In: C. Rosenzweig \& R. Dickinson (Eds), Climate Vegetation Ineteraction, Proceedings of a woakshop held at NASA/ Goddard Space Fight Center, Greenbelt, Maryland, 1986.

JOHANSSON, Erik. Urban Design and Outdoor Thermal Comfort in Warm Climates.Int J. Biometorol. 2006

HARAZONO, Y, et. al. Effect of Rooftop Vegetation using Artificial Substrates on the Urban Climate and the Thermal Load of Buildings. Energy and Buildings, Netherlands, n.15-16, 1990/91, p. 443-446. 
HOLM, R. G. et al. Surface reflectance factor retrieval from Thematic Mapper data. Remote. Sensing. Environment, v. 27, 1989, p.47-57.

HONJO, T.; TAKAKURA, T. Simulation of thermal effects of urban green areas on the surroundings areas. Energy and Buildings, Netherlands, n.15-16, 1990/91, p. 435-442.

HOSOI, F. OMASA, K. Voxel-based 3-D modeling of individual trees for estimating leaf area density using high-resolution portable scanning lidar. IEEE Transactions on Geoscience and Remote Sensing, v. 44, 2006, p.3610-3618.

KARVONEN, P. Influence of global climatic change on different hydrological variables, 2003. Disponível em: < http://www.water.tkk.fi/wr/kurssit/Yhd-

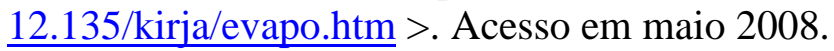

KATZSCHNER, L. Urban climate studies as tools for urban planning and architecture. In: IV Encontro Nacional de Conforto no Ambiente Construído, 1997, Salvador. Anais. Salvador: FAUUUFBA/LACAM-ANTAC, 1997, p.49-58.

KIMBALL, B.A., et al. Effects of increasing atmospheric $\mathrm{CO}_{2}$ on the growth, water relations, and physiology of plants grown under optimal and limiting levels of water and nitrogen. In: Response of Vegetation to Carbon Dioxide. US DOE, Carbon Dioxide Research Division, USDA-ARS, Washington DC, N. 39, 1986.

KONJINEDIJK, C.C., RANDRUP, T.B., NILSSON, K., Urban forestry research in Europe: an overview. Journal of Arboriculture, v.26, n.3, p. 152-161, 2000.

KONJINEDIJK, C.C. A decade of Urban Forestry in Europe. Forest Policies and Economics, v.5, p.173-186, 2003.

KOSHIZAWA, A., 1991. Tokyo doshikekaku monogatari (História do planejamento urbano de Tóquio). Nihhon Keizai Hyorun-Sha Publishers, Tokyo.

KUHNS , M. Planting Trees For Energy Conservation: The Right Tree in the Right Place. Utah State of University. 2008. Disponível em: < http://extension.usu.edu/forestry/HomeTown/Energy_TreesandEnergy.htm >. Acesso em janeiro de 2009.

KUO, F. E.; SUlLIVAN, W. C.; COLEY, R. L. ; BRUSON, L. Fertile ground for community: inner-city neighborhood common spaces. American Journal of Community Psychology, v. 26, n.6, 1998, p.823-851.

LABORATÓRIO DE CONFORTO E EFICIÊNCIA ENERGÉTICA - LABAUT. Sustainable Urban Spaces. Intermediate report: context studies and the strategy for environmental/ sustainable urban design. Colaboração Internacional Brasil-UK. (Relatório de Pesquisa de acesso restrito). FAUUSP. São Paulo, 2006. 
LALIC, B; MIHAILOVIC, D. T. An empirical relation describing leaf-area density inside the forest for environmental modelling, J.Appl. Met., 2004.

LANDSBERG, H. E. The Urban Climate. New York: Academic Press, 1981.

LAURIE, M. Clima y Microclima. Barcelona: Gustavi Gili, 1983.

LOMBARDO, M. Ilha de calor nas metrópoles. São Paulo: Hucitec, 1985.

LUTTIK, J. The value of trees, water and openspaces as reflected by house prices in the Netherlands.Landscape and Urban Planning, Vol. 48, 2000, p.161-167.

MASSON, V. A physically-based scheme for the urban energy balance in atmospheric models. Bound.-Layer Meteor. V. 94, 2000.

MASSON, V. et al. Evaluation of the Town Energy Balance (TEB) Scheme with Direct Measurements from Dry Districts in Two Citie. Journal of Applied Meteorology, 2002, p. 1011-1026.

MARTINCIGH, L. Planning Policy on Urban Greenspaces in three EU countries, 2000. Disponível em: < http://www.map21ltd.com/Citynat/nat-pol.htm >. Acesso em fevereiro 2008.

MARTILLI et al. On the impact of urban surface exchange parameterisations on air quality simulations: the Athens case. Atmospheric Environment, vol. 37, n. 30, p. 42174231, 2002.

MAYER, H. e HOPPE, P. Thermal Comfort of man in different urban environments. Theoretical and Applied Climatology. n38. 1987. p.43-49.

MAYOR OF LONDON. East London Green Grid - Prime, 2006.

MCPHERSON, E.G. et al. Desert Southwest Community Tree Guide: Benefits, Costs and Strategic Planting. Phoenix, AZ: Arizona Community Tree Council, 2004. Disponível

em: <http://www.fs.fed.us/psw/programs/cufr/products/001_cufr542_72dpiDsrtSWCommTr eeGd04.pdf > . Acesso em maio de 2007.

MCPHERSON, E.G. et al. Desert Southwest Community Tree Guide: Benefits, Costs and Strategic Planting. Phoenix, AZ: Arizona Community Tree Council, 2004. Disponível em: <http://www.fs.fed.us/psw/programs/cufr/products/001_cufr542_72dpiDsrtSWCommTr eeGd04.pdf > . Acesso em maio de 2007.

MEIR, P; GRACE, J.; MIRANDA, A.C. Photographic method to measure the vertical distribution of leaf area density in forests. Agricultural \& Forest Meteorology. n.102. 2000. p.105-111. 
MERIGGI, M. Gren Structure. IN ITALIAN PLANNING - LAWS, POLICIES, CHALLENGES - COST Report, 2002. Disponível em: < http://www.map21ltd.com/COSTC11/italy.htm >. Acesso em março de 2008.

MILLER, R.W. Urban Forestry Planning and Managing Urban Greenspaces, Prentice Hall, New Jersey, 1988.

MILLER, R.W. Urban Forestry: Planning and Managing Urban Greenspaces. 2.ed. Upper Saddle River, NJ: Prentice Hall, 1997.

MILLS, G. An Urban Canopy-Layer Climate Model, Theoretical and Applied Climatology vol. 57, n. (3-4), 229-244, 1997.

MONTEIRO, C. A. F.; MENDONÇA, F.Clima Urbano. São Paulo: Universidade de São Paulo, Série Teses e Monografias, n..25. 1976.

MONTEITH, J.L. et al. The measurement and control of stomatal resistance in the field. Journal Appy. Ecology, v. 2, 1965, p. 345-355.

MONTEITH, J.L. Principles of environmental physics. Londres: Edward Arnold Ltd. 1973, p.241.

MOTT, K.A. Sensing of atmospheric $\mathrm{CO}_{2}$ by plants. Plant, Cell Environ, v.13, 1990, p.731-737.

NIKOLOPOULOU, M.. Designing open spaces in the urban environment: $a$ Bioclimatic approach. Ruros: Rediscovering the Urban Realm and Open Spaces. CRES - Centre for Energy Resources, Department of Buildings, Greece, 2004.

NIKOLOPOULOU, M. Vegetation in the Urban Environment. The Integration of Renewable Energy Sources in Buildings and the Urban Environment, (eds.) CRES, ALTENER, Atenas, 2003.

NIKOLOPOULOU, M; BRUSE, M. Urban Green Space in Europe: New approaches for practitioners. In: 3rd GREENCLUSTER International Conference, Utrecht, 2004.

NIELSEN, A. B.; NILSSON, K. Urban forestry for human health and wellbeing. Urban Forestry Urban Greening, v.6, 2007, p. 195-197.

NILSSON, K.; RANDRUP, T. B. Urban and peri-urban forestry. In: XI World Forestry Congress, 1997, Antalya, Turkey, v.1.

NOWAK, D. et.al. The Urban Forest Effects (UFORE) Model: Field Data Collection Manual, 2005. Disponível em: < www.fs.fed.us/ne/syracuse/Tools/downloads/UFORE_Manual.pdf >. Acesso em dezembro de 2008. 
O DIÁRIO NORTE DO PARANÁ. Árvores de Maringá ganham RG.2007. Disponível em: < http://www.rgdaarvore.net/news.php?id=8 >. Acesso em janeiro de 2009.

OKE, Tim R. The energetic basis of the urban heat island. Quartely Journal of the Royal Meteorology Society, vol..108, n.455, p.1-24, jan.1982.

OKE, Tim R. Boundary Layer Climates. 2ed. Routledge and John Wiley \& Son; London, New York, 1987.

OKE, Tim R. The Micrometeorology of the Urban Forest. J. Phil. R. Sec. Land. B324, 1989.

OKE, Tim R. Evapotranspiration in urban areas and its implication for urban climate planning. In: Conference Teaching the Teachers on Building Climatology. Proceedings. The Nacional Swedish Institute for Building Research, v.2, 1973.

ONG, Boon Lay. Green Plot Ratio: An Ecological Measure for Architecture and Urban Planning. Landscape and Urban Planning, vol.63, p.197-211, 2002.

OMETO, J. C. Bioclimatologia Vegetal. Agronômica Ceres. São Paulo, SP. 1981.

PAULEIT, S. et al. Tree establishment practice in towns and cities Results from a European survey. Urban Forestry Urban Greening, v.1, p.83-96, 2002.

PENMAM H.L. Natural evaporation from open water, bare soil and grass. In: Proceedings of the Royal Society of London, v.A193, p.120-146, 1948.

PEPER, P.J; MCPHERSON, E.G. Comparison of five methods for estimating leaf area index of open-grown deciduous trees. Journal Arboriculture, vol.24 , n.2, p.98-111, 1998.

PHILLIPS, P. L. Real Estate Impacts of Urban Parks. Economic Research Associates. 2000.

PIMENTEL, D. et al. Environmental and economic costs of soil erosion and conservation benefits. Science, v.267, 1995, p.1117-1123. Disponível em: < http://www.sciencemag.org/cgi/content/abstract/sci;267/5201/1117 >. Acesso em janeiro 2008.

PINTY B., et al. Radiation Transfer Model Intercomparison (RAMI) exercise: Results from the second phase, Journal Geophys. Res., vol.109, D06210, 2004.

PRATA, A. R. Dimensionamento do impacto da altura de edifícios nas condições de ventilação natural do meio urbano simulando em túnel de vento: o caso de Santos. 2005. Tese (Doutorado em Arquitetura e Urbanismo) Faculdade de Arquitetura e Urbanismo, Universidade de São Paulo, São Paulo, 2005. 
PREFEITURA DE CURITIBA. Plano Municipal de Controle Ambiental $e$ Desenvolvimento Sustentável. 2007. Disponível em: < http://www.curitiba.pr.gov.br/servicos/MeioAmbiente/PlanoAmbiental/DIAGNOSTIC O_AMBIENTAL_DO_MUNICIPIO_DE_CURITIBA.pdf $>$. Acesso em Janeiro de 2008.

PROW, T. Power of Trees. Illinois Steward, v. 7, n.4. 1999. Disponível em: < http://www.lhhl.uiuc.edu/media/thepoweroftrees.htm >. Acesso em janeiro 2009.

RONINETE, G. O. Plant, people and environmental quality. Washington D.C. Department of the interior, National Park Service, 1972.

ROSS, J; ROSS, V; KOPPEL, A. Estimation of leaf area and its vertical distribution during growth period, Agri. Forrest Met., 2000.

ROTACH, M. W. On the influence of the Urban Roughness Sublayer on turbulence and dispersion. Atmospheric Environment, vol. 33, n. 24-25, p. 4001-4008, 1999.

ROWLAND-BAMFORD, A.J.; NORDENBROCK, C.; BAKER, J.T.; BOWES, G.; ALLEN, L.H. Jr. Changes in stomatal density in rice grown under various $\mathrm{CO}_{2}$ regimes with natural solar irradiance. Envir. Exp. Bot. v.30, 1990. p.175-180.

SACRAMENTO TREE FOUNDATION. State of Trees Report. 2000. Disponível em: $<$ http://sactree.com/aboutUs/state-of-trees.pdf > Acesso em outubro de 2007.

SAILOR, D. J. Simulated urban climate response to modifications in surface albedo and vegetative cover. Journal of Applied Meteorology, v.34, 1995.

SAN FRANCISCO BOARD OF SUPERVISORS. Legislative Analyst Report, 2001. Disponível em: <http://www.sfgov.org/site/uploadedfiles/bdsupvrs/leganalyst/02100_Tree\%20_Progra ms.pdf >. Acesso em março de 2008.

SANTAMOURIS, M.Energy and Climate in the Built Environment. James and James, London, 2001.

SÃO PAULO. Secretaria Municipal de Planejamento Urbano. Atlas Ambiental do Município de São Paulo. São Paulo, 2000: SEMPLA, 1985, 358p. Disponível em: <http://atlasambiental.prefeitura.sp.gov.br/> Acesso em: 10 mar 2006.

SAXENA, M. Microclimate modification: Calculating the effect of trees on air temperature, 2001. Disponível em: <http://www.sbse.org/awards/docs/Saxena.pdf\#search='SAXENA\%2C\%20Mudit. $\% 20$ Microclimate\%20modification>.

SECRETARIA MUNICIPAL DO MEIO AMBIENTE. Plano Diretor de Arborização Urbana. $2008 . \quad$ Disponível em:

$\quad<$ 
http://lproweb.procempa.com.br/pmpa/prefpoa/smam/usu_doc/resolucaoo_5_comam_re publicacao_final.pdf $>$.Acesso em fevereiro de 2008.

SHASHUA-BAR, L.; HOFFMAN, M. E. Quantitative Evaluation of trees effects on diurnal air temperatura cooling in urban streets. 2002.

SIMPSON, J. R., Mcpherson, E. G. Estimating cost effectiviness of residential yard trees for improving air quality in Sacramento, California, using existing models. Atmosferic Environment, vol.32, n.2, 1998, p.75-84.

SHASHUA- Bar, L; SWAID, H; HOFFMAN, M. E. On the Correct Specification of the Analytical CTTC Model for predicting the Urban Canopy Layer Temperature. Energy and Buildings, vol. 36, n.9, p. 975-978, 2004.

SOUZA, S.R. et al. Emissão por folhas de Ficus beijamina L. (Moraceae) de compostos orgânicos voláteis oxigenados. Revista Brasil. Bot., vol. 25, n.4, p. 413-418, 2002. Disponível em: <http://64.233.169.104/search?q=cache:bpagZFMGIP8J:www.scielo.br/pdf/rbb/v25n4/a $\underline{05 \mathrm{v} 25 \mathrm{n} 4 . \mathrm{pdf}+\mathrm{hidrocarbonetos}+\text { naturais } \& \mathrm{hl}=\mathrm{pt}-\mathrm{BR} \& \mathrm{ct}=\mathrm{clnk} \& \mathrm{~cd}=10 \& \mathrm{gl}=\mathrm{br}}>$. Acesso em abril de 2008.

SOUZA, T; DUARTE, D. Reading and Graphic Representation of the Urban Environmental Conditions. Case study: Paulista Avenue. In: PLEA 2004 - THE 21st CONFERENCE ON PASSIVE AND LOW ENERGY ARCHITECTURE, 2004, Eindhoven. Built environments and Environmental Buildings. Eindhoven: Plea International, 2004. v. 1, p. 565-570.

SPANGENBERG, Jörg. Improvement of urban microclimate in tropical metropolis - A case study Maracanã. Rio de Janeiro, 2004. Dissertação (Mestrado de Arquitetura). Faculdade de Arquitetura e Urbanismo, Rio de Janeiro, 2004.

SPIRN, A. W. O jardim de granito. São Paulo: EDUSP, 1995.

STADT, K. J; LIEFFERS V.J .MIXLIGHT: a flexible light transmission model for mixed-species forest stands, Agri. Forrest Met., vol.102, p.235-252

STEEMERS, K.; YANNAS, S. Architecture, City, Environment. In: Passive Low Energy Architecture, 17, Proceedings. International Passive and Low Energy Architecture Conference. Cambridge: PLEA, 2000. London: James\& James, 2000.

STEEMERS, K., STEANNE, M. A. Environmental Diversity in Architecture. Spon Press. London, 2004.

STEWARD, J.B; Modeling Surface Conductance of Pine Forest. Agric. For. Meteorol., vol.43, p.19-35, 1988. 
TAHA, H. et. al. (1992) The impact of trees and white surface on residential heating and cooling energy use in four canadian cities. Energy, v.17, n. 2, 1992, p.141-149.

TAHA, H. Urban climates and heat islands: albedo, evapotranspiration, and anthropogenic heat. Energy and Buildings, n.25, 1997, p. 99-103.

TARIFA, J. R, A., Tarik R.Os climas na cidade de São Paulo. Teoria e prática. São Paulo: Pró-reitoria de Cultura e Extensão. USP: laboratório de Climatologia. FFLCH, 2001. (GEOUSP - Coleção Novos Caminhos, 4).

TELLES, L. O. Vegetação pode contribuir com parte do ozônio presente na região metropolitana de São Paulo. Agência USP de notícias. 2003. Disponível em: <http://www.usp.br/agenciausp/repgs/2003/pags/061.htm >. Acesso em abril de 2008.

TOKYO METROPOLITAN GOVERNMENT, Basic Policies for the 10-Year Project for Green Tokyo, 2007. Disponível em: < http://www.kankyo.metro.tokyo.jp/kouhou/english/pdf/Project\%20for\%20Green\%20To kyo.pdf >. Acesso em fevereiro de 2008.

TROWBRIDGE, P. J.; BASSUK, N. L. Trees in the Urban Landscape. John Wiley\& Sons. 2004.

TSUBO, M.; WALKER. Relationships between photosynthetically active radiation and clearness index at Bloemfontein, South Africa. Theoretical and applied Climatology sep. 2004.

ULRICH, R. et al. Stress recovery during exposure to natural and urban environments. Journal of Environmental Psychology, v.1, 1991, p.201-230.

ULRICH, R. Gardens Have The Potential To Improve Health. Science Daily, 2003. Disponível no site: <http://www.sciencedaily.com/releases/2003/11/031124071045.htm> Acesso em outubro 2007.

URBAN FORESTRY COUNCIL. San Francisco Great Strees Program, 2005. Disponível em: <http://www.sfgov.org/site/uploadedfiles/sfdpw/projects/Divisadero_Wkshp2_PowerPo int.pdf $>$. Acesso em dezembro de 2007.

Urban Forestry Council. Urban Forest Plan, 2006. Disponível no site: $<$ http://www.sfenvironment.org/downloads/library/urbanforestplanmay06.pdf $>$. Acesso em dezembro de 2007.

VIANNA, Nelson S. O Estado da Arte em ensino e pesquisa na área de conforto ambiental no Brasil. Dissertação (Mestrado em Arquitetura e Urbanismo) Faculdade de Arquitetura e Urbanismo, Universidade de São Paulo, São Paulo, 2001. Disponível em: <http://www.geros.com.br> Acesso em: 9 março de 2006. 
VINET, $\mathrm{J}$ et al. Modelling the Impact of Urban Vegetation to Analyse Urban Microclimate and Indoor Thermal Comfort. In: Passive Low Energy Architecture, 17, Proceedings. International Passive and Low Energy Architecture Conference. Cambridge: PLEA, 2000.. Proceedings. London: James\& James, 2000.

VOOGT, J.A. Urban Heat Islands: Hotter Cities. 2004. Disponível no site: <http://www.actionbioscience.org/environment/voogt.html > Acesso em: 9 março de 2006.

WAGGONER, P. E.; REIFSNYDER, W. E. Simulation of the temperature, humidity, and evaporation profiles in a leaf canopy. J. Appl. Meteor., v. 7, 1968, p.400-409.

WANG R. et al Comprehensive concept planning of urban greening based on ecological principles: a case study in Beijing, China. Landscape and Urban Planning, v. 72, 2005, p.325-336.

WILLIAMSON, T. J; ERELL E. Thermal performance simulation and the urban microclimate measurement and predicition. Seventh International IBPSA Conference Rio de Janeiro, Brazil, 2001.

WOODWARD, F.I. Stomatal numbers are sensitive to increases in $\mathrm{CO}_{2}$ from preindustrial levels. Nature, v.327 1987, p.617-618.

WOLFE, D.W. Physiological and growth responses to atmospheric carbon dioxide concentration. Handbook of Plant and Crop Physiology. M. Pessarakli (ed.). Marcel Dekker, New York, 1994,p. 223-242.

YANNAS, S. Living with the city. Urban design and Environmental Sustainability. In: Environmentally Sustainability. In: Environmentally Friendly Cities. Proceedings of PLEA'98. Lisbon: James and James, 1998.

YEANG, K.. The Green Skyscraper: The Basis for Designing Sustainable Intensive Buildings. Prestel Verlag. 1999.

YIN, X. The albedo of vegetated land surfaces: Systems Analysis and Mathematical Modeling. Theoretical and Applied Climatology, vol.60, p.121-140, 1997.

YU, C.; HIEN, W. N. Thermal benefits of the city parks. Energy and Buildings, n.38, 2006, p. 105-120. 